Historic, archived document

Do not assume content reflects current scientific knowledge, policies, or practices. 




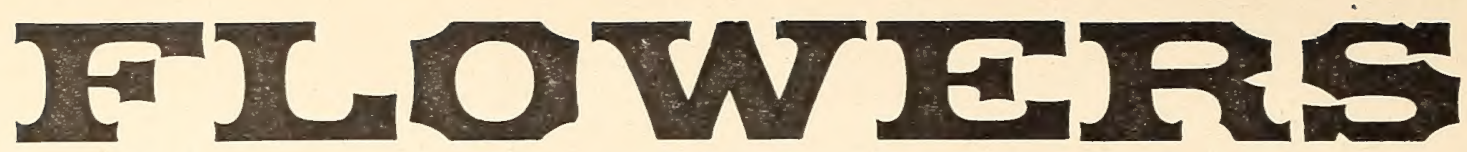

\title{
Floral Arrangements and Decorations.
}

DESICIS, EMBLEMB, BASIETS, BOUQUETS.

\section{LOOSE FLOWERS OF ALL KINDS AT ALL SEASONS. OUR SUPPLY PRACTICALIY UNLIMITED.}

\author{
VARIETY AND QUALITY UNEXCELLED. ALL FLOWERS GUARANTEED FRESH.
}

T. EING always fully alive to the importance of this branch of our business, and being greatly encouraged by the annual increase in the trade, we were not only the first in our city to build greenhouses especially and exclusively for the cultivation of plants to supply cut-flowers only, but we have unremittingly kept in view the requirements of the trade and the demands of our patrons, and have from time to time made additions to our greenhouses, and, in every way suggested to us, increased our facilities for producing and handling large quantities of flowers, so that to-day we are justified in saying we have the most extensive range of greenhouses for the production of cutflowers and the best equipped store, exclusively devoted to this special trade, in the Northwest. Furthermore, it has always been our aim not only to supply such flowers as are popular and in demand, but also to introduce every new thing suitable to the trade and worthy of attention.

WE ARE NOW IN A POSITION TO SUPPLY EVERY DEMAND.-It must be evident that the product of any one florist's establishment is more or less limited, and that it would be at least impracticable to grow such quantites of flowers as might at certain times be in demand, flowers being such perishable articles they cannot be kept fresh beyond a day or two. However, by special arrangements and contracts we now have with several of the large wholesale flower growers, easily accessible, men who make a specialty of growing flowers to supply dealers such as ourselves, we now have at command almost unlimited quantities of the very choicest flowers at all seasons, for in addition to the large quantities we ourselves produce, we receive daily shipments from these establishments under contract with us, the supply being limited only by our demands.

WE NEVER FAIL TO FILL AN ORDER if sufficient time is allowed us. Generally a very short time suffices, although for our own and our customers' sake we desire all the time the circumstances will permit; we are thereby better enabled to do full justice to the order.

\section{Our Out of Toun Trade- Facilities for Receiving and Filling Orders We reeeire mail fre

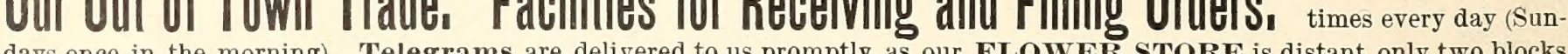 from the main Telegraph Offices; and Telephone Messages are received direct in our office from all accessible points. The main offices of all Express Companies are in the next block from our store, so that an order for a quantity of loose flowers can be boxed and delivered in the Express office in teu minutes after its receipt, and almost any ordinary floral piece for party, wedding or funeral in less than an hour (we have often succeeded in doing this in half an hour), as our compe- tent staff of workmen, assisted by every facility known to the trade, accomplish their work well and expeditiously.}

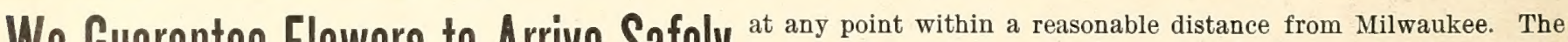
We Guarantiee Flowers to Arrive Safelly and trials of many plans, enables us to send the most deficate flowers and elaborate floral pieces many hundreds of miles, and have them reach their destination in perfect condition. For their safe transit and delivery we are also indebted to the Express Companies, who are very careful of all of our packages.

Elnwore moy ho Rroford by MAIL, TELEGRAPH or TELEPHONE. In ordering by mail or telegraph be

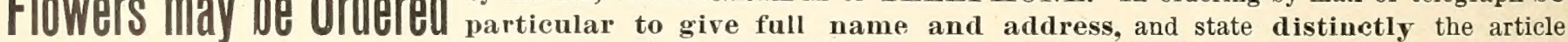
required and when you wish it shipped or the time you wish it to arrive. If floral pieces are required for some special purpose, and customers cannot determine what to choose as most appropriate, if the selection is left to us we always carefully exercise our best judgment to send that which is suitable. Persons unknown to us will please give satisfactory city references, or send cash with their orders; or, if so desired, we will ship C. O. D.

WE MAINTAIN REASONABLE PRICES, varying somewhat at certain seasons, but generally, as compared with those of a few years ago, they are very low, placing even the choicest flowers within the reach of every one.

Extensive Decorations a special feature of our trade. Estimates on all work cheerfully furnished on application.

Particular attention paid to getting up Original and Suitable Designs when requested for special occasions.

We carry a large assortment of the latest styles of Baskets and Floral Designs suitable for the trade. CURRIE BROS., Seedsmen and Florists, 


\title{
Currie Bros."
}

(9) $\mathrm{s}$ (I)

\section{HORTICULTURAL GUIDE}

(0)

FOR

\section{GARTEIN AND FARIM.}

\section{SPRING NUMBER, 1892.}

\section{TO OUR READERS}

\begin{abstract}
UR numerous customers, who deal regularly with us, and now know us so well, may deem the following
remarks entirely superfluous, since they are mainly what we have repeated annually for a number of years. We do not wish to be credited with egotism, but since our "Guide" is every year materially increased in numbers in both issues--Spring and Fall-and as a matter of course falls into the hands of many readers who, perhaps, know no more of us than what they have learned from a brief advertisement, we consider it our duty, for their benefit as well as our own, to acquaint them of our business, and our facilities and capabilities for conducting it.
\end{abstract}

OUR BUSINESS BRIEFLY OUTLINED.-The simple statement that we are Seedsmen and Florists might be sufficient, yet, as it applies to the business we conduct, it is, we fancy, scarcely explanatory enough. As Seedsmen WE GROW AND INTRODUCE NEARLY ALL THE NOVELTIES WE OFERR, and. large quantities of other seeds we deal in are either grown by or especially for us.

OUR SEED STORE, at 312 Broadway, a commodious building of four floors, is stocked not only with seeds of all kinds, but also with fertilizers, tools, implements; everything, in fact, for the farm and garden. We are also agents for all kinds of heavy farm implements and machinery.

SEEDS FOR THE GARDEN AND FARM of every Grain, Vegetable and Ornmental Plant, worthy of culture in our climate, we keep in stock in sufficient quantity to supply every demand.

NOVELTIES, as we have stated, are either of our own introduction, or are obtained direct from the originators; but we are always very cautious of cataloguing anything until we are satisfied it possesses some real merit.

SEEDS BEARING OUR NAME are those which we have introduced, and are really of a very superior character, all of them having been thoroughly tested before being put on the market. They are exclusively held and controlled by ourselves.

SEEDS TRUE TO NAME.-We use every precaution our experience can devise to have all seeds true to namo, and we never, under any circumstances, substitute one seed for another, and cal it by any other than its true name.

SEEDS ARE TESTED, A PRECAUTIONARY MEASURE OF GREAT VALUE TO OUR CUSTOMRRS AND OURSELVES.-Our greenhouses and gardens afford us every facility to test seeds, and none are allowed to leave our establishment until we are satisfied that they are absolutely of the very best quality, possessing the greatest possible vitality.

THE VALUE OF GOOD SEEDS.-The successful gardener can never be persuaded to buy anything but the very best seed, and that, too, of the very best varieties of the kinds of vegetables he wishes to grow, no matter what it costs. He is, therefore, very particular about where and of whom he buys his seeds.

As gardeners and florists, being born in the business, we early learned the value of a good seed and the utter worthlessness of a bad one. As seedsmen, therefore, of nearly seventeen years' standing, we are enabled to appreciate the importance of dealing only in good seeds, so that our customers shall get just what we would be anxious to secure were we the buyers instead of the sellers.

We never sow a seed of doubtful quality except to test it, and we never sell a seed unless we have the utmost confidence in it, knowing it to be of the very best quality, having within it the germ of a first-class plant. And although we are under the necessity of having many of our seeds grown for us, we are very careful to employ only the most experienced and most reliable seed-growers engaged in that profession; and furthermore, on no consideration do we purchase a seed of a grower whose reputation is at all doubtful. WE MUST HAVE THE VER BEST SEEDS, AND WE USE EVERY PRECAUTION TO SECURE THEM.

OUR SEEDS, therefore, are the very best, and we know them to be absolutely pure and of the very finest grades.

THE VARIETIES WE OFFER of grains, vegetables and plants are the best introduced, all the best and only the best. The market gardener and farmer cannot afford to grow anything but the best, and the private gardener has no satisfaction in anything, however slightly inferior it may be. We are, therefore, very particular in making our selection of varieties. 
DO WE WARRANT SEEDS ? - While we guarantee all our seeds to be of the very best quality, and from the finest stocks, and certain to grow under favorable conditions, yet, as there are so many circumstances, most of them quite beyond human control, which may cause the utter failure of seeds of even the greatest vitality, we are compelled, in justice to ourselves, and to avoid possible complications, to impress most explicitly and emphatically upon our customers that we do not guarantee our seeds to grow, neither do we in any sense hold ourselves responsible for the failure of any crop. We wish it clearly understood that in these respects our seeds are sold without any warranty, expressed or implied.

Experienced gardeners and farmers fully understand the many adverse circumstances which may result in the failure of seeds to germinate, or cause their total destruction even after they have passed that critical stage. It may be drought or too much moisture, a too low temperature of soil or atmosphere, a too loose or too compact soil, or improper treatment, owing to carelessness or lack of knowledge, which may cause the failure of seeds to germinate; or during germination, when the young plants are so small and delicate that even a sudden change of temperature, or a blast of cold or hot and dry wind, to say nothing of the ravages of the numerous insect enemies, may at any moment totally destroy them, and the crop is lost. It will be readily seen that the seedsman is powerless under all of the circumstances to avert failure; but knowing how apt beginners especially are to charge him with selling bad seeds, he, as in our case, adopts the precautionary measure we have mentioned.

WE WARRANT the safe arrival of seeds. In the event of the non-arrival of packages, or their receipt in bad condition, if notice is sent us within two weeks after date of shipment, we will cheerfully replace the same.

WE WARRANT REASONABLE PRICES.-First-class goods at reasonable prices is our motto. We invite comparison of our prices with those of any reliable seedsmen in the United States, and we are confdent ours will be found as low as any. $R \geqslant$ member that reliable seeds cannot be bought as cheaply as those of an inferior quality, and we do not deal in any of a doubtful character.

THIS SEASON'S STOCK, we are very pleased to say, is of a very superior quality. The seeds of all kinds of grains, vegetables and flowers are thoroughly matured, and are, from appearances and the tests they have been subjected to, full of vitality and great vigor. They are exceptionally clean and are, in fact, of a more than ordinary high grade. All roots, too, are very fine. POTATOES, of which we have a large stock of all the leading kinds, and several NEW VARIETIES, are EXCEPTIONALLYGOOD. We have, therefore, great satisfaction in offering our stocks this season, being confident that they must prove satisfactory.

WHEN TO ORDER SEEDS. - Beyond question, the proper time to send in orders is just as soon after the receipt of this catalogue as that can be conveniently done. Not only does it give us plenty of time to fill orders, but is sometimes in other respects a great convenience to us, and likewise a benefit to those ordering, in this respect. Although we carry a large stock, it is evident that, as we cannot foresee the demand, we are liable at times, particularly as the season advances, to run short of some kinds; an early receipt of orders enables us to avoid that difficulty and customers get what they want without delay. It also enables purchasers, on receipt of their seeds, should they then discover that they have omitted something in ordering, to send again, and have the omitted article arrive in season.

HOW TO ORDER SEEDS, ETC.-In making out orders be careful to give your full name and address, plainly written, to prevent mistakes and delay; and please state distinctly whether large quantities are to be sent by express or freight, otherwise we shall use our own judgment regarding the best route.

In ordering packages sent C. O. D., sufficient money must be enclosed with the order to pay express charges both ways, so as to protect us from loss, as it sometimes happens that persons do not receive goods on their arrival, and the express charges may be more than the value of the package.

SEEDS BY MAIL.-Purchasers of seeds will please note that all seeds in packets are sent free by Mail to any Postoffice or Express Office in the United States; but those ordering quantities of one-half pound, or pint and upwards, will please add to the catalogue price of seeds a sufficient amount to cover expense of postage, namely, 8 cents per pound; 15 cents per quart of Beans and Peas, and 10 cents per quart of Sweet Corn.

Since these and larger quantities are most frequently ordered sent by express or freight, we deem it advisable to adhere to what has always been our custom of listing seeds at their true value, leaving it to the purchaser to add the necessary amount for postage when he desires them sent by mail. Experience has taught us that this plan saves both vurselves and our customers much trouble and annoyance. We wish, then, to direct particular attention to this important fact, that while we do not offer, as some seedmen do to-day, to forward all seeds postpaid, it will be found, on making comparison, that the actual prices of our seeds are as low as those of any first-class and reliable seedsman in the country.

\section{GREENHOUSES AND PLANT DEPARTMENT.}

A lifetime of experience in plant culture has taught us many valuable lessons in the construction of greenhouses, so that our ranges, as they stand to-day, are not only the most extensive in our city, but they are in every respect most complete and serviceable. Briefly stated, the secret of our success in this branch of our business is a painstaking consideration of the wants of our customers, and close and prompt attention to them ; a careful selection of plants of the best kinds, new and old, and those best adapted for the various uses they are to be put to ; a close study of the requirements of every class of plants, and a strict observance of the best methods of cultivation. Our greenhouses, too, as we have said, are as near perfect and as completely fitted up as it is possible to have them, and all the gardeners we employ are active men of long experience and devoted to their profession. Furthermore, it has always been our greatest care to deal fairly, honestly and liberally with our customers. 
NOVELTIES.-It will be seen that a number of the plants we offer are new or of very recent introduction, but all have been thoroughly tried to test their qualities before giving them a place in our lists. All are really excellent of their kind, and should find a place in every collection of plants. To place them within the reach of everybody, we offer them at extremely low prices.

BEDDING PLANTS.-Our stocks of these this year are again, we are happy to say, fully equal to any we have ever offered.

CONSERVATORY AND PARLOR PLANTS.-We feel especially proud of the stock of plants we are growing and preparing for conservatory or parlor culture. A finer lot of Palms, Ferns, Begonias, Lilies, Fuchsias, Geraniums, etc., we have never seen. We have them in all sizes, from the $\boldsymbol{L} \boldsymbol{A} \boldsymbol{R} \boldsymbol{E} \boldsymbol{S} \boldsymbol{S} \boldsymbol{P} \boldsymbol{E} \boldsymbol{C} \boldsymbol{I} \boldsymbol{E} \boldsymbol{N}$ to the smallest cutting or seedling, so that we are prepared to fully supply all demands.

HOW WE SHIP PLANTS.-Small plants to distant and outlying points, and in small quantities, are quite frequently sent by mail, and we exercise every care to have them reach their destination in good condition; but we cannot recommend this means of carrying plants, in fact we always discourage it, knowing it to be most unsatisfactory, and we only resort to it when compelled by circumstances.

ORDER PLANTS SENT BY EXPRESS.-For the same money we will gladly send a much larger plant by express than we possibly could by mail. The soil is all left on the roots; the plants can be more carefully packer, and they are sure to arrive in good condition and receive no check to their growth. To encourage a preference fo. this means of having plants sent, we not only send larger and better plants, but we always add enough extra to compensate for the additional expense of expressage.

All packages are delivered free of charge to all depots and express offices in Milwaukee, and no charge is made for boxes, baskets or packing.

SAFE ARRIVAL OF PLANTS GUARANTEED.-We guarantee all plants to arrive safely and in good condition, if sent by express. We will cheerfully replace any or all plants not received in good condition, if $\boldsymbol{n o t i c e}$ is sent us immediately on receipt of the plants. We do not hold ourselves responsible for plants which have: been received in good condition, but which may afterwards from some cause fail to grow. Neither do we take any risk on plants sent in any other way but by express.

HOW TO TREAT PLANTS WHEN RECEIVED.-Plants sent by express usually arrive in such perfect condition that no special treatment is required. If they should be dry, soak the balls of soil in cold water before potting or planting them. When sent by mail to a considerable distance they are liable to gat dry. If they should look wilted, place them in tepid water for a short time and they will soon revive; then pot into as small pots as will conveniently hold the roots, or if planted immediately in the garden, press the soil, which should be well pulverized, firmly around the roots; water and shade for a few days.

PRICES.-Following our usual custom, we this year maintain the same reasonable, in fact low prices, we have always aimed at. We believe we have never failed to give our customers entire satisfaction, always making them feel that they have received full value for their money. This year we have the utmost assurance, knowing the superiority of our stock of all kinds of plants, that we can give fully as good, if not better, satisfaction than we have in any previous year. At any rate, we were never so well satisfied ourselves with the appearance of all our plants as we are at present. Remember, also, that we are $I I B E R A L W I T H I X T R A S$, according to the value of the order.

GARDEN TOOLS AND REQUISITES.-Of these we carry a complete and extensive line. For detailed description and prices, see end of "Guide."

\section{How TO EcanomizE.}

\section{"A PENNY SAVED IS A PENNY EARNED."}

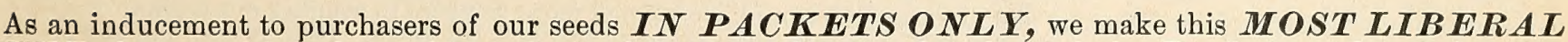
$\boldsymbol{O F \boldsymbol { F }} \boldsymbol{F}$, but we wish it thoroughly understood that it applies to orders for seeds in Packets only, and not to orders for an ounce or more :

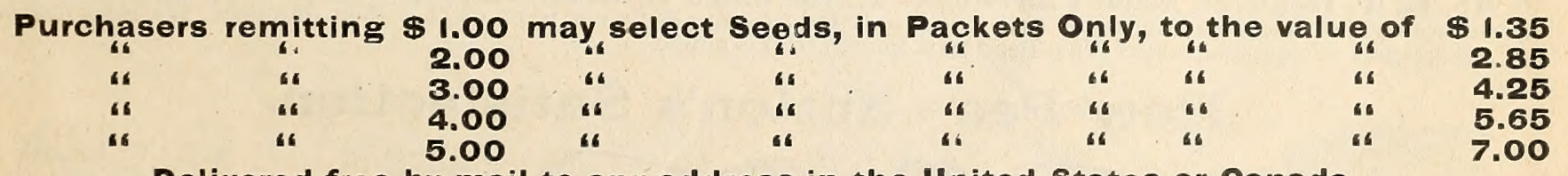

Delivered free by mail to any address in the United States or Canada.

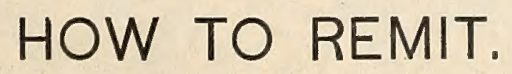

Money may be sent at our risk and expense, in the fullowing m inner: P. O. money order, drafts on New York, Chicago, or Milwaukee, or Express order. Postal notes, and money sent in any other way than as specified above, is entirely at the risk of the sender.

CURRIE BR0S., 108 Wisconsin Street and 312 Broadway, Milwaukee, Wis. 


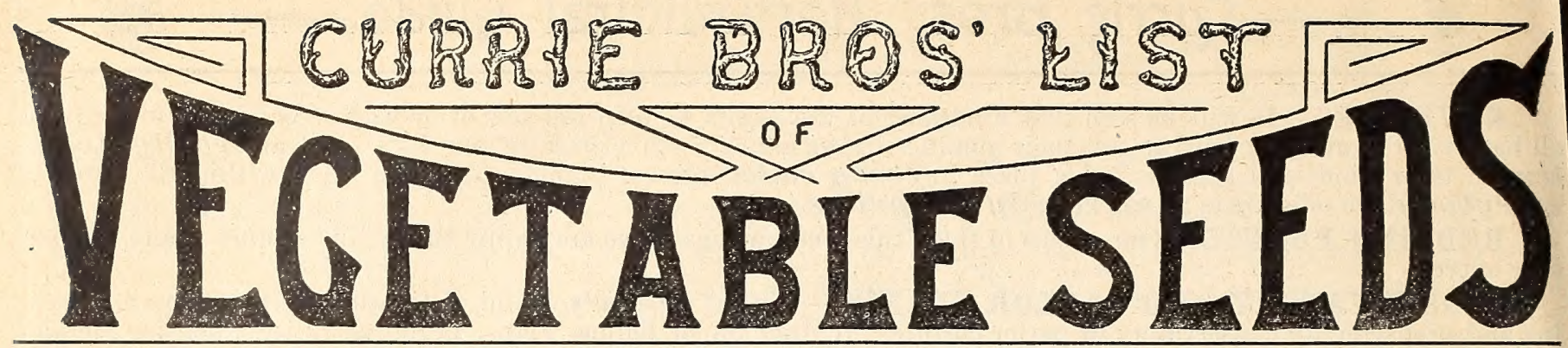

\section{IVETT AIVD IVOVEI VAFIETIES.}

\section{CURRIE'S RUST-PROOF GOLDEN WAX BEAN.}

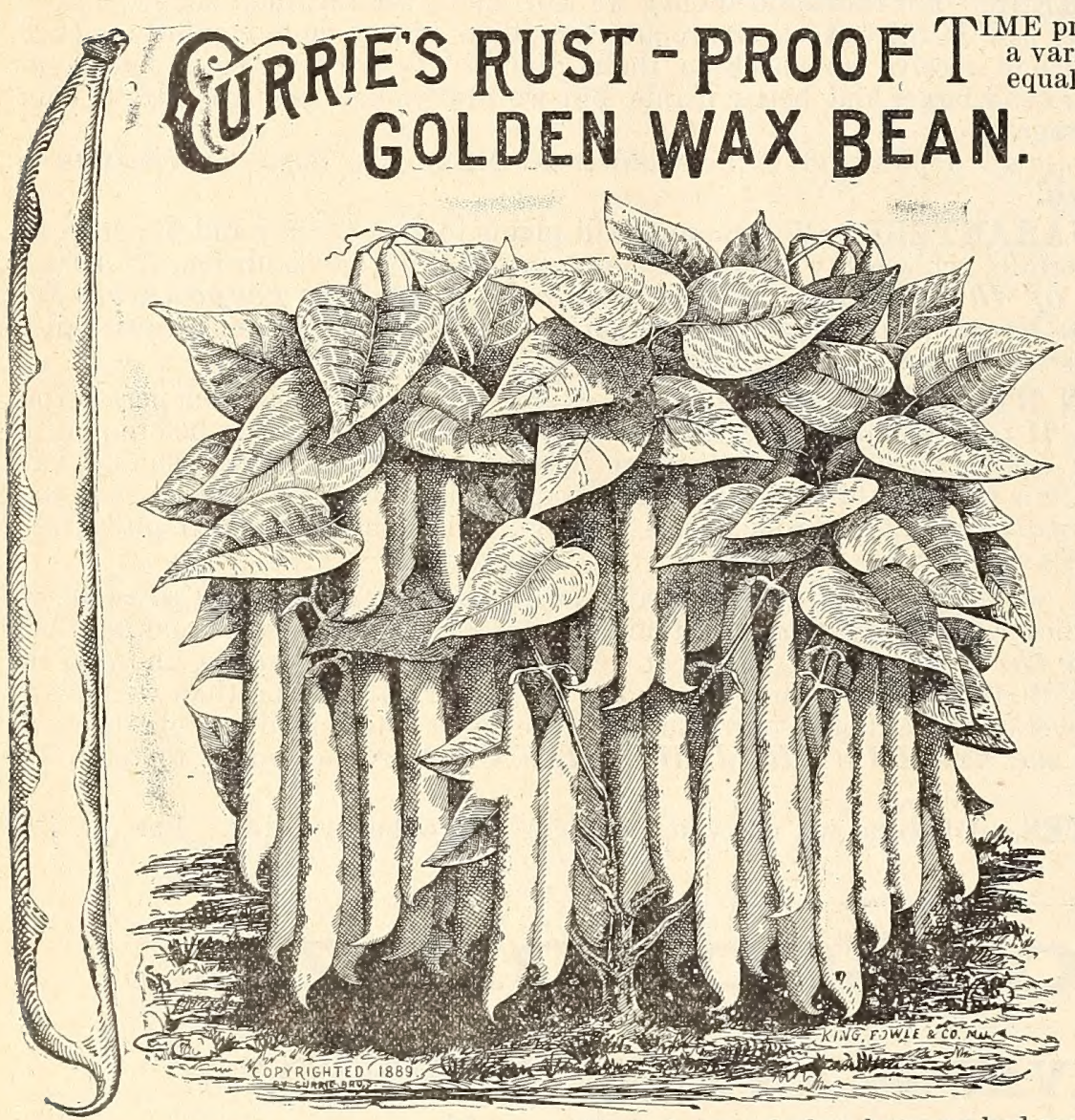

usually seen if properly grown. We may add, that never before have we had more pleasure in sending out a plant or seed, or had more confidence in any which we recommended to the public, than this trulylwonderful Bean. Pkt., 10 cts.; pint, 20 cts.; quart, 35 cts.; peck, $\$ 2.00$; bushel, $\$ 8.00$

1 r. II. 'T'. Hopkins, Cape Vincent, N. Y., the noted Bean grower, says: "I have watched carefully your Rust-Proof Golden W ax Bean since you first sent it out, and time has shown it to be what it then promised, the most desirable in every respect of any flat-podded Wax Bean now known to the public."

\section{New Pea-Sutton's Satisfaction.}

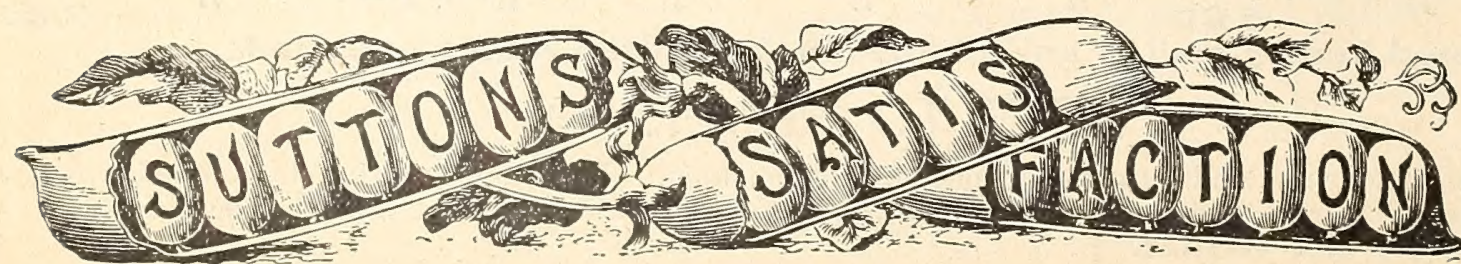

A NEW English Pea A which promises to supersede the now famous Stratagem and Telephone, possessing all their excellent qualities, and is the most delicious flavored of all varieties, either of American or foreign origin. The vines grow vigorously to a height of two and a half feet, requiring no brush, being very stocky and robust, and litcoll-flled pods, which come into use soon after the extra early varieties. The Peas when green are unusually large and of a fine deep-green color. Pkt., 10 cts.; pint, 30 cts.; quart, 60 cts. 


\section{CURRIE'S ECLIPSE CABBAGE.}

U6

have now the satisfaction of knowing, beyond a doubt, that our predictioas of last year, concerning this Cabbage, were well-founded, and we now fully realize what we possess in "The Eclipse," a variety unequaled by any now in the market as a second early. The numerous unsought-for tesimonials we have received, regarding its merits, from market gardeners, and others, in every section of the country, are alone sufficient proof of its great value. The demand for seed of it, this season, is now far ahead of our most sanguine hopes.

THE ECLIPSE is the Earliest of all large Cabbages, and while it is considerably larger than Henderson's Early Summer, it is fully two weeks earlier than that variety. The heads grow very uniform in size, with few loose leaves, remarkably solid, very tender and of the finest quality. The veins and midribs of the leaves are also very much smaller than other varieties. Color dark green. THE ECLIPSE is all that can be desired as an early Cabbage, and it has the further inerit of being a valuable sort for main crop.

The stem is very short. That, coupled with the compact habit of its growth, makes it valuable, inasmuch as many more Cabbages can be planted on an acre than of most large.headed sorts.

Many large growers who know say: "The three best Cabbages for the Market Gardener are CURRIES' EARIY MARKET, ECLIPSE and LONG KEEPING.'

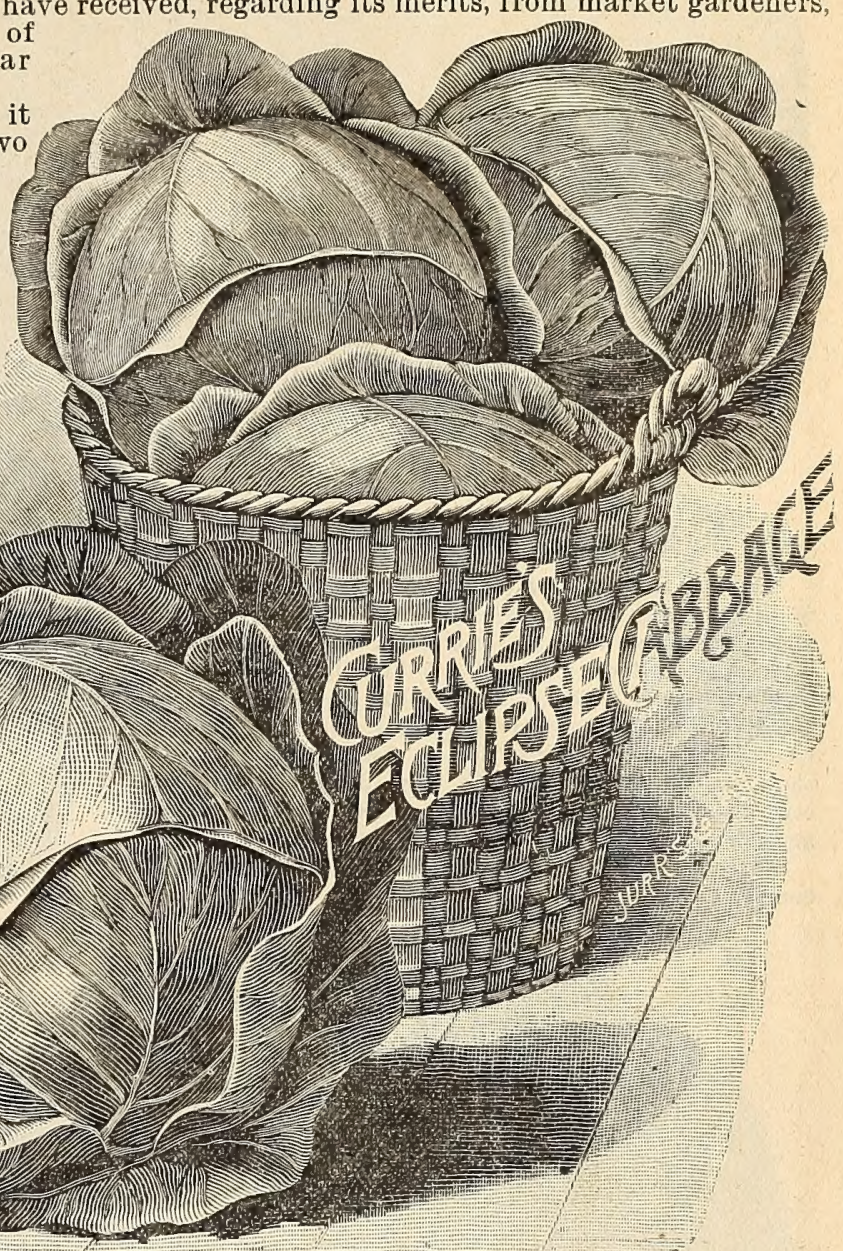

\section{CURRIE'S EARLY MARKET CABBAGE.}

Now Recognized as the Best Allround Early Cabbage in Cultivation.

Market gardeners everywhere who have grown it are unanimous in pronouncing it a most desirable variety, very early, of excellent quality, tender and very mild in flavor when cooked. Comparing it with Wake field, we find it earlier than that standard sort, besides having a much
larger and firmer head, with few loose outside leaves. In fact, in weight it is fully equal to many of the second early varieties, and may, with advantage, be grown throughout the entire season. In form the head is conical, like all early varieties.

Market gardeners in this section now grow this variety as their standard extra-early sort, and judging from the many flattering testimonials we every year receive from every section of the country where we have introduced it, it bids fair to become universally popular, and be the accepted extra-early Cabbage for market and family use.

Pkt., 10 cts. ; oz., 40 cts.; $1 / 4$ lb., $\$ 1.25 ; 1$ lb., $\$ 4.00$.

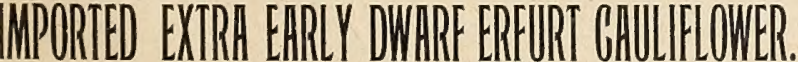

This variety is obtained from a selection of the largest and earliest heads, and is unsurpassed in quality. We have it grown for us by the most experienced growers in Europe, and the greatest care is taken to have it pure; and the large demand we have for the seed proves, beyond doubt, that our efforts in that direction meet with success. Poor, cheap Cauliflower seed is a dear gift, and we would caution everyone to buy nothing but the best, which can only be obtained at a high price. For forcing, this variety is unequaled, and is equally well adapted for late planting. It is dwarf and compact in habit, thereby accommodating almost a half more plants on the space occupied by the taller growing varieties. When grown under favorable circumstances almost every plant will produce a snow-white head 9 to 10 inches in diameter. Pkt., 25 cts.; oz., $\$ 4.00$. 


\section{FOUR EXCELLENT NEW}

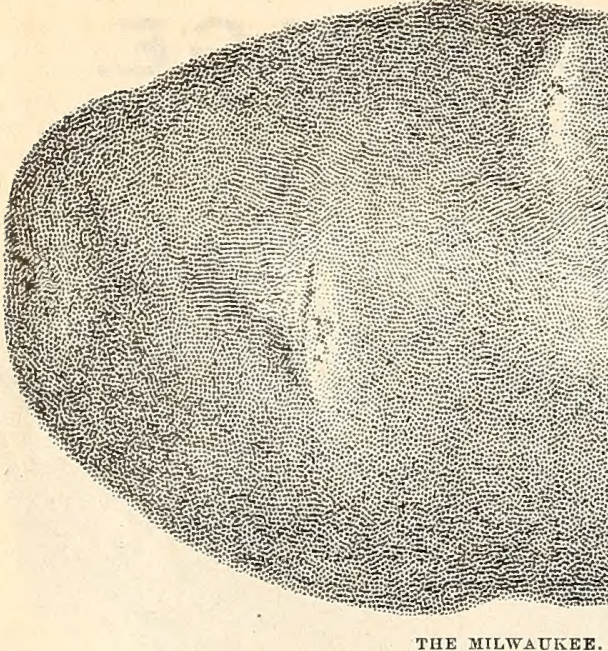

EARLY WISCONSIN.

An extra early variety destined to take a leading place where earliness and quantity are deeired. It is a very large yielder abounding in light sandy soils, that combined with its extreme earliness makes it a most valuable potato for early marketing. It is also an excallent keeper. It resem bles Beauty of Hebron in many respects, only that it is rose colored, and a much heavier yielder. The tops are stout and short, and the tubers are easily dug. Besides being a firstclass market sort it will be found an excellent family potato and one that will be especially valuable in Southern markets.

Price 35 cts. per Ib., post-paid: $\$ 1.00$ per peck: $\$ 2.50$ per bushel.

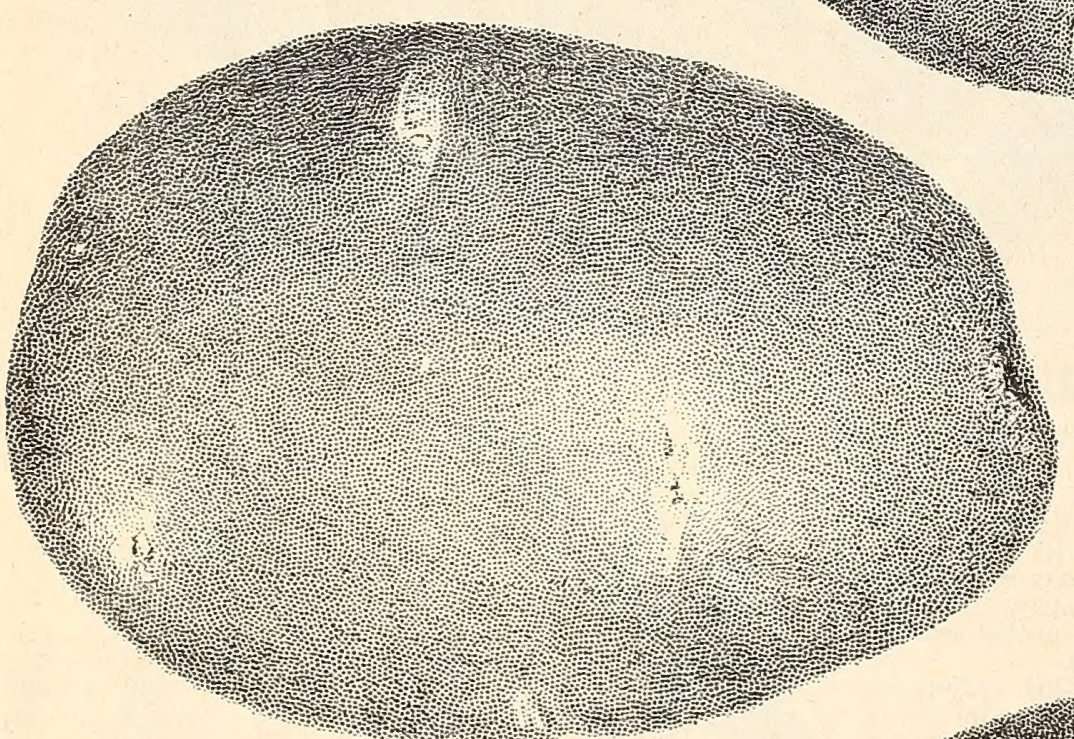

An excellent New Early Potato resembling Crown Jewell in appearance, but of larger size and very much superior in quality. It is a strong grower with very strong tops, and comes into use fully as early as Early Sunrise, yielding however a much larger crop than that variety, and has the further merit of being a first-class keeper, and may be depended upon to remain in good condition without sprouting until very late in the season. If grown in rich black losm it will produce a very heary crop of handsome large tubers of very fine quality.

Price per lb., 35 cts; $\$ 100$ per peck, $\$ 2.50$ per bushel.

\section{THE MILWAUKEE.}

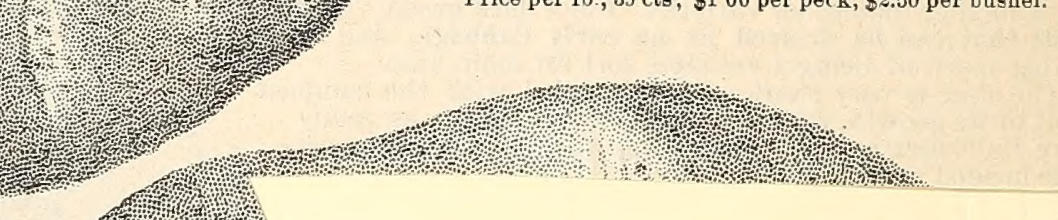

SNOWFLAKE JUNIOR.

\section{SATISFACTION.}

This new potato possesses many excellent qualities to recommend it to the rower and consumer. It is early coming into use, about the same time as Early Ohio. In some respects it resembles Early Thorburn, only the tubers are more inclined to roundness. It yields most a vundantly and its cooking qualities are the very best; as a baker it has no superior. For hotel purposes we think this variety is especially worthy of commendation. It also keeps well, and is in every respect a first clase market potato.

Price per lb., $35 \mathrm{cts.,}$ poetpaid; $\$ 1.00$ per peck; $\$ 2.50$ per bushel.

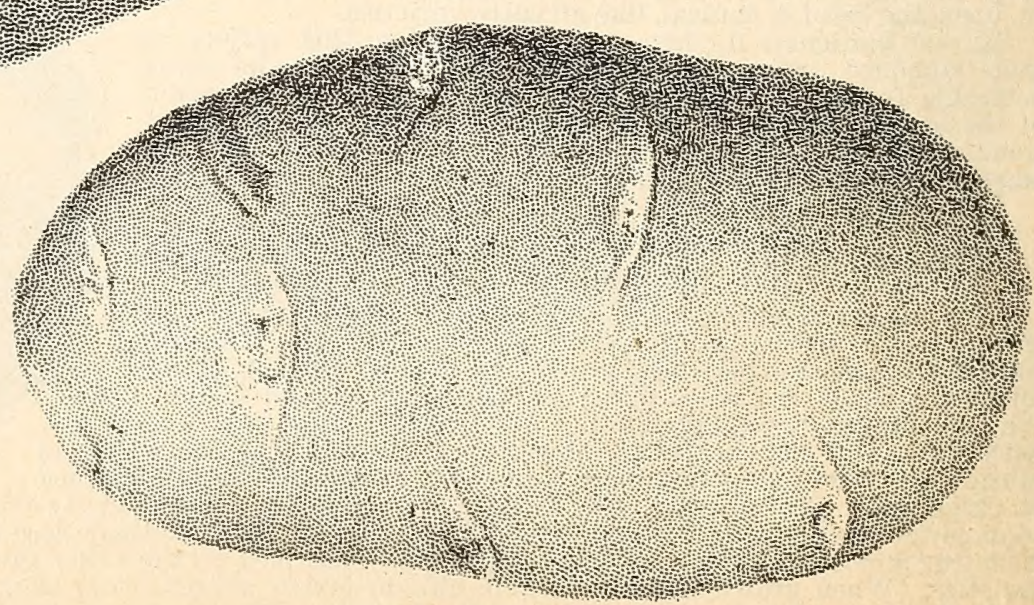




\section{feneral List of Vegetable SEEDS.}

\section{ARTICHOKE-Globe. \\ German, Artischoke. \\ French, Artichant.}

Sow in April in hot-bed or boxes, and when the ground is rendy transplant in hills three feet apart, and the rows two feet apart.

Large Green Globe-The standard variety. Pkt., 10 cte. ; oz., 30 cts.; 1/4 lb. .90

\section{ARTICHOKE-Jerusalem.}

Grown for Its tubers, which resemble Potatoes, and should be planted in a atmilar manner, on'y that the rows should be at least four feet apart. Peck, $\$ 1.00$; bushel.

\section{ASPARAGUS.}

German, Spargel.

French, Aeparge.

As early in the spring as the ground can be worked, sow the seeds, previously soaked in water for about twenty-four hours, in rows about a foot apart. During the flrst season the young plants must be carefully attended to. Cultivate between the rows frequently to keep the soil loose and weeds down. Remove all weeds in the rows by hand-picking. The second year the plants will be ready for planting in permanent beds. Prepare these beds by trenching to a depth of at least two feet, and working in a liberal quantity of barn-yard manure. These beds should be about 2 feet apart and three feet wide, and 3 rows only should be planted in each, the plants being placed from 15 to 18 inches apart in the rows, or when large quantities are grown for market, the plants should be et in rows 3 feet apart, and the plants about one foot apart. This plan admit of horse cultivators being used. In planting, spread out the roots carefully and cover with ahout 6 or 8 inches of soil. A rather sandy eoil suits this plant best.

If by mail in quantities of $1 / 2 l b$, and upwards, add 8 cts. per lb. for postage.

1 oz. to o 0 feet of drill.

Colossal-A well known and excellent variety. Pkt., 5 c's.; oz., 10 cts.; $3 / 4$ lb., $20 \mathrm{cts}$; $1 \mathrm{lb}$. .

Palmetto-An earlier and more productive variety than the preceding, and one which we think will finully supersede it. Pkt., 10 cts.; oz., 20 cts. ; $3 / 4$ 1b., $50 \mathrm{cts} ; 1 \mathrm{lb} . . . . .$.

Glant Argenteull-A very large variety. A large grower thus deseribes It: "My Argenteuil Asparagus is a great success. I could bave cut larger stalks from that set a year ago than from a bed of Coloseal set 20 years."

Pkt., 10 cte.; oz., 25 cts.; 1/4 lb.; 75 cte.; $1 \mathrm{lb}$.

\section{ASPARAGUS ROOTS.}

Colcssa1-Two-yesr-old routs, by express, per 100, 75 cts.; per $1,000 \ldots \ldots .6 .00$ Palmetto-

$$
\$ 1.50 \text {; }
$$

\section{BEANS-Dwarf or Bush.}

\section{German, Bohne.}

French, Haricot

Begin sowing the 1st of Mas, if the ground is in fit condition. For successive crops sowinge may be made every two or three weeke, until the 18t of September. Sow thinly in drills from 2 to 3 inches deep, and from 18 inches to 2 feet apart. If the soll is rather poor, the former depth will suffice; if rich, the latter.

If by mail in quantities of a pint and upwards, add 15c. per quart for postage.

1 quart to 100 feet of drill, 2 bushels to the acre in hills. CURRIE'S RUST-PROOF' GOLDEN WAX-Enormously productive, very tender, exquisite flavor, rich golden color and entirely free from rust. (For description see Novelties.) Pkt., 10c; pint, 20c; quart, $35 \mathrm{c}$; peck, 82.00; bushel.

DATE WAX-One of the earlest of the wax varieties, being fully as early as Golden Wax, and is very prolific. Pkt., 5 cts.; pint, 15 cts.; quart, 25 cte. ; peck. \$1.t0; bushel............................6. 60 GOLDEN-EYED WAX-An early variety, very hardy, a sure cropper, very productive and of good quality. Pkt., 5 cts.; pint, 15 cte.; quart, 30 cts.; peck, \$1.75; bushel.

BLACK-EYED WAX-A robust grower, producing a profusion of pode, which resemble those of the Black Wax. Pkt., 5 cts.; pint, 15 cts ; quart, $30 \mathrm{cts}$; : peck, 81.75 ; bushel

IMPROVED PROLIF $C$ BLACK WAX-This Bean originated from the old Black $\mathrm{Wax}_{\mathrm{ax}}$, but is much superior to its parent. It is much more productlve and the pode are longer, straighter and rounder, Pkt., 5 cte.; pint, 15 cte. ; quart, 25 cts.; peck, $\$ 1.50$; bushel.......................6.6.

Golden Wax-One of the best Snap Beans. Pkt., 5 cts.; pint, 15 ctr.; quart, 25 cts. ; peck, 81.25 ; buebel..............................5.

Black Wax, or Butter-A popular medium early sort. Pkt., 5 cts. ; plnt, $15 \mathrm{cts}$; q11art, $25 \mathrm{cts}$; peck, $\$ 125$; bushel ,........................4.75

Orystal White Wex-A productive and excellent variety. Pkt., 5 cts.; plnt, 15 cts. ; quart, 30 cts. ; peck, $\$ 1.50$; bushel .................... 5.50

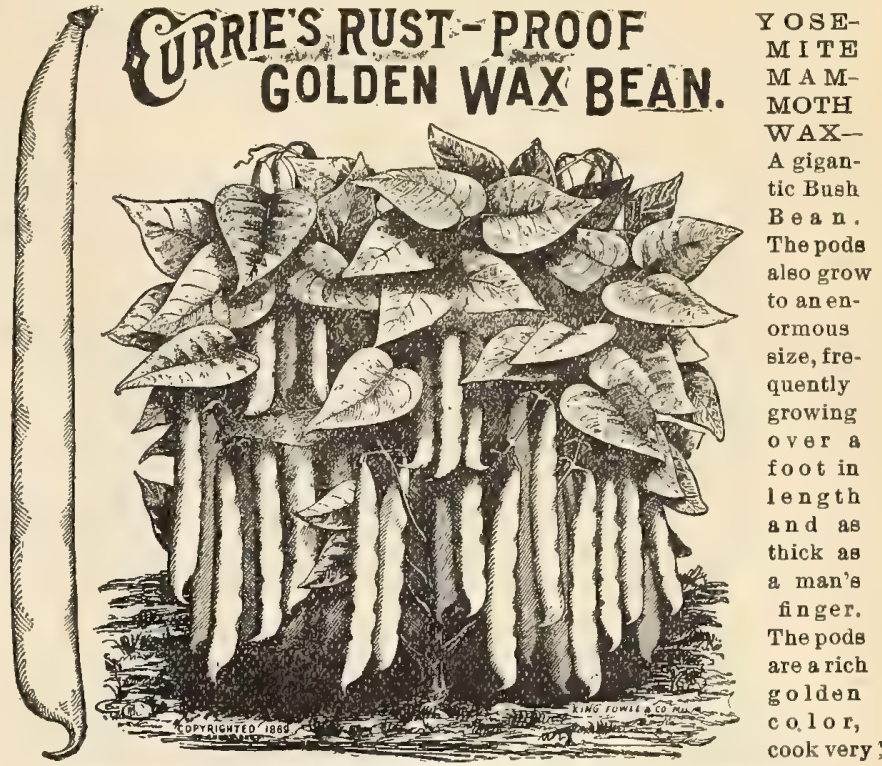

tender, and of very fine flavor. It has the further merit of being very productive. Pkt., 10 cts.; piut, 30 cts.; quart, 50 cts.; peck, $\$ 3.00$; bushel... $\$ 12.00$ IMPROVED GOLDEN WAX-An improvement on the old Golden Wax. Pods larger and more prolific. Pkt., 5 cts.; pint, 20 cte. ; quart, 30 cts.; peck, $\$ 1.50 ;$ bushel.....................................6.0

White Seeded Wax-Except in the color of its seed, this variety bears s strong resemblance to the Black-reeded Wax. Pkt., 5 cts.; pint, 15 cte. quart, 25 cts. ; peck, $\$ 1.50$; bushel............................... 5.00

FLAGEOLET WAX-A valuable variety, coming in about the same time as Golden and Black Wax. Pods large. Very productive. Pkt, 5 cts.; pint, 15 cts. ; quart, 30 cts. ; peck, $\$ 1.75$; buehel ...................7.0

Ivory Pod Wax-Also a etringless variety and one of the best. Pkt, 5 cts.; pint, 15 cts. ; quart, 30 cts.; peck, $\$ 1.50$; bushel....................6.00 Dwarf Mont d'Or-Early, of vigorous growth, and very productive. Pkt., 5 cte. ; pint, 15 cts. ; quart, 30 cts.; peck, $\$ 1.50$; bushel...........6.00 WARDWELL'S KIDNEY WAX BEAN-Is as early as the Golden Wax, very prolific, hardy, and is a strong grower. The pods are large and handeome. Pkt., 5 cts.; pint, 15 cts. ; quart, 30 ete.; peck, $\$ 1.50$; bushel..5.50

\section{GREEN PODDED VARIETIES.}

EXTRA EARLY ROUND-PODDED VALENTINE-This is one of the very best snap Beans, being very early and of first-class quality. The pods are round and fleshy, and very crisp and tender. Pkt., 5 cte.; pint, 15 cts. ; quart, 30 cte. ; peck, $\$ 1.25 ;$ bushel......................... 4 .

White Valentine-An excellent Bean, very productive and of fine flavor. Pkt., 5 cts.; pint, 15 cts. ; quart, 25 cts.; peck, $\$ 1.25$; bushel..............4.00

Early Red Valentine-One of the best early varieties. Very productive and continues green and tender for a longer period than the majority of the varieties. Pkt., 5 cts. ; pint, 15 cts.; quart, 25 cts. ; peck, $\$ 1.00 ;$ bushel.4.00 IMPROVED ROUND POD VALENTINE-Similar to the preceding variety, only that the pods are round and larger. It is also a stronger grower, and yielde better. Pkt., 5 cts.; pint, 15 cts.; quart, 25 cts.; peck, $\$ 1.00$; bushel 4.00

NE PLUS ULTRA-A very early Bean, enormously productive, pode fat. Pkt., 5 cts. ; pint, 15 cts. ; quart, 30 cts. ; peck, $\$ 1.50$; bushel..............5.00 EMPEROR WILLIAM-The largest podded and the earlieet of all the Bush varieties. It is a very large cropper, pods flat. Pkt., 5 cts.; pint, 15 cts.; quart, 30 cts. ; peck, $\$ 1.50 ;$ bushel...........................5 00

EXTRA EARLY RMFUGEE-Similar in sll respects to the old Refugee, only that it is two weeks earlier. It ie very prolific. Pkt., 5 cts.; pint, 15 cts. ; quart, 30 cts.; peck, $\$ 1.50$; bushel........................5.00 GOLDEN REFUGEE-A variety quite distinct from the old Refugee, having round pode very light in color; of fine flavor, tender and criep; very productive. A very desirable Bean. Pkt., 5 ctø. ; pint, 15 cts.; quart, 25 cts.; peck, $\$ 1.25$; bushel.

Early Yellow Kidney Six Weeks-Excellent variety, very early and productive. Pkt., 5 cts.; pint, 15 cts.; quart, $25 \mathrm{cts}$; peck, $\$ 1.00$; bushel ..4.00 Early Mohawk-Early, of excellent quality, and productive. Pkt., 5 cts.; pint, 10 cts. ; qusrt, 20 cts. ; peck, $\$ 1.00$; bushel....................4.00 Early China Red-Eye-A favorite early variety. Pkt., 5 cts.; pint, 10 cts.; quart, 20 cts.; peck, $\$ 1.00$; bushel ... ........................... 3.75 
Refuge日, or One Thousand to One-Not so early as the preceding varieties, but excellent for a main crop. Very productive, tender, and favor delicions. Pkt., 5 cts.; pint, $10 \mathrm{cts.;} \mathrm{quart,} 20 \mathrm{cts.;} \mathrm{peck,} \$ 1.00$; bushel.

Pride of Newtown-A very robnst grower, and an sbundant yielder. Pods long and flat and light green. Very early. Pkt, 5 cts.; pint, 20 cts.; quart, 35 cts.; peck, $\$ 1.75$; bushel.

HENDERSON'S BUSH LIMA-A variety that growa only abont 18 inches high and produces large crops. Pkt., 10 cts.; pint, 25 cts.; quart, 50 cts.; peck, $\$ 3.00$; bushel.

LOW'S CHAMPION BUSH-A late variety, possessing the double merit of being equally well adapted for a shell or snap Bean. The pods resemble those of the Lima somewhat in shape; very tender and of fine flavor. It is a very prolific ylelder. Pkt., 5 cts.; pint, 15 cts.; quart, 25 cts. ; peck, \$1.25; buebel

Dwarf Horticultural-A Bush variety of the popular Pole Bean of that name. Pkt., 5 cts.; pint, 15 cts. ; quart, 25 cts. ; peck, $\$ 1.25$; bushel.......4.50

White Marrowfat-Not specially good as a string Bean, but very popular shelled, green or dry. This variety is grown in large quantities for conaumption in a dry state. Pkt., 5 cts:; pint, 10 cts.; quart, 20 cts.; peck,

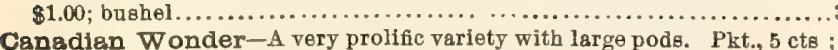

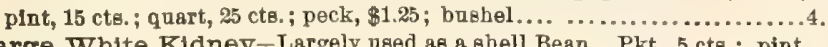
Large White Kldney-Largely used as a shell Bean. Pkt., 5 cts.; pint, For Field Varieties, see list of Farm Seeds, page 29.

\section{BEANS-Pole or Running. French, Haricot or Rames.}

These are sown in hills about four feet apart, dropping five or six seeds in esch hill, to the depth of sbout 2 inches. Being more tender than the Bush varieties, the planting of them ehould be delayed about two weeke after the usual time for planting the latter. A sandy soil suits them best, but the hill

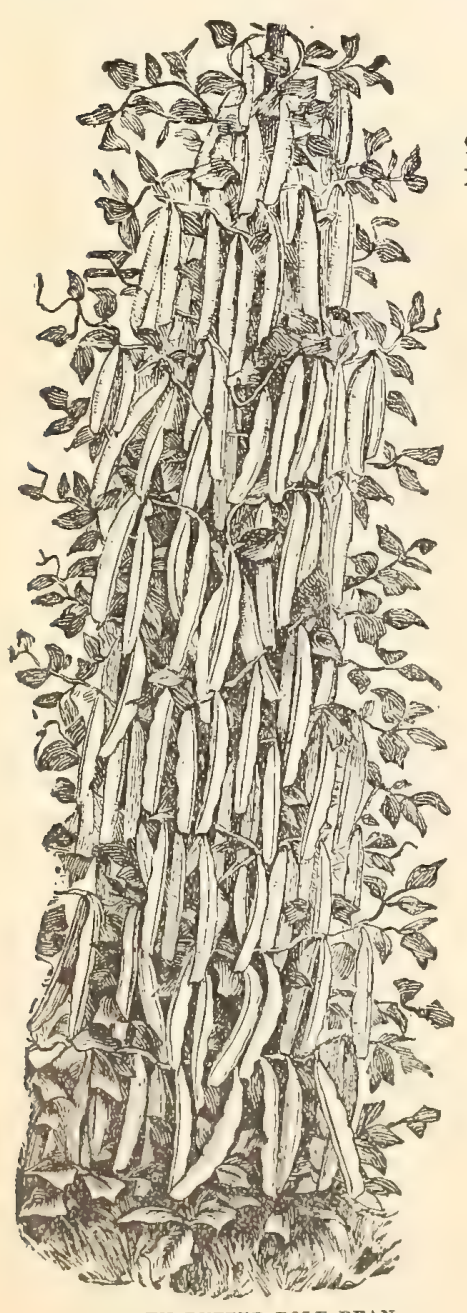
should have a liberal quantity of manure worked in previous to planting the seed.

1 quart to 150 hills, 10 to 12 quarts per acre.

EARLY GOLDEN CLUSTER WAX POLE-This variety in earliness, coming into use from a week to ten days later than the dwarf Golden Wax. The beautiful golden yellow pods, which are from 6 to 8 inches long, are borne in clusters in the greatest profusion, and continue to bear until.frost comes. It is crisp and tender, and of the most delicious flayor. Pkt , 5 cts. ; pint, 20 cts.; quart, 40 cts. ; peck, $\$ 2.00$; bushel.....8.00

\section{FORD'S MAMMOTH POD-} DED LIMA-As the nam $\theta$ implies, this new Bean is of great size. The poda nanally grow seven or eight inches in length, and contain from five to seven large Beans. These are equally good in the green or dry state. The plant is a very etrong grower, and sets its pode early, and continues to produce fruit abundantly until cut down by frost in fall. Pkt., 10 ctø.; pint, 25 cts. ; quart, 50 cts.; peck, $\$ 3.00$; busbel..

GOLDEN ANDALUSIA-One of the moet productive Beans yet introduced, it being nothing anueual to pick over one half bushel from a single vine at one picking. The pods are broad, thick, very fleshy and entirely stringless, and when fully grown are five to gix inches long; $e x$ ceedingly rich and fine flavored when cooked. Pkt., 10 cts, ; pint
German, Stangen-Bohne. takes the lead of all pole Beans

EXTRA EARLY LIMA-In appearance and sige similar to the large white Lima, and of equally good quality. It is especially valuable on account of being two weeks earlier than the ordinary Lima. Pkt $\mathbf{5}$ cts. pint, 20 cts.; quart, 40 cts.; peck, $\$ 2.00$; bushel.. ................... $\$ 8 . \infty$ Large White Lima-A very popular variety, largely grown for market. Pkt., 5 cts. ; pint, 15 cts. ; quart, 30 cts. ; peck, $\$ 2,00$; bushel............7.50 Small Lima, or Sleva-This variety is smaller than the large Lima, hardier and eomewhat earlier. Pkt., 5 cts.; pint, $15 \mathrm{cts}$; quart, 30 ctв. peck, $\$ 2.00$; bushel .7 .50

Dreer's Improved Lima-Early and very productive, and very superior in flavor; an excellent variety. Pkt., 5 cts.; pint, 15 cts.; quart, socte.; peck, $\$ 2.00 ;$ bushel........................................ 8.00

KING OF THE GARDEN LIMA-A strong and rapid grower. It eets its Beans early and produces throughout the season an abundant supply of enormous pods measuring from 5 to 8 inches in length, well filled with Beans of excellent quality. Pkt., 10 ets.; pint, 20 cts, ; quart, 40 cte.;

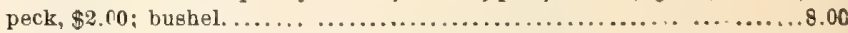

GOLDEN BUTTER POLE, OR TALL MONT D'OR-An excellent variety of vigorous growth and very productive. The pods are of large size, measuring from 7 to 8 inches, snd are of a traneparent yellow color; free from strings; crisp and tender. It produces its pods while the vines are very young, and continues to bear profusely thronghout the entire season. Pkt., 5 cte.; pint; 20 cts. ; quart, 35 cts.; peck, $\$ 2.00$; bushel....8.00 Farly Dutch Caseknife-Excellent for general use, whether green or dry. Pkt,, 5 cts.; pint, 15 cts. ; qusrt, 30 cts.; peck, $\$ 1.50$; bushel........6.00 Giant Wax-Very productive; pode waxy yellow, of remarkable alze, but very tender and of excellent flavor. Pkt., $5 \mathrm{cts}$; pint, 20 cts.; quart, 40 cts.; peck, $\$ 250$; bushel. 9.00

Horticultural, or Speckled Cranberry-Much grown in private gardens. Is highly esteemed green, or when more matured, shelled. Pkt., 5 cts.; pint, 15 cts. ; quart, 30 cts.; peck, $\$ 1.75$; bushel ................6.00 Scarlet Runner-A very old but popular varlety, much used for ornamental purposes. Pkt., sc.; pint, 15c.; quart, 30c.; peck, 81.50 ; bushel. .6.00

\section{BEANS-English or Broad.}

\section{German, Gartenbohne. French, Feve de Marais.}

Plant early in spring in rows about 4 feet apart, seeds 4 inches apsrt in the row and 2 inches deep. As soon as the lower pode are set, pinch the top off the plants to insure well-filled pods. Perfectly hardy

Broad Windsor-The best. Pkt., 5 cts.; pint, 20 cts. ; quart............. .40

\section{BROCCOLI.}

German, Spargelkohl. French, Chow Brocoll.

Allied to and closely resembling the Caulifower, but much more hardy. Sow the seed in the early part of May and transplant to permanent plaoe in. June.

If by mail in $1 / 27 b$. quantities or over, add sufficient to cover postage at the rate of 8 cents per $l b$.

Purple Cape-A hardy and very popular varlety; very rarely falle to pro-

duce a good head. Pkt., 5 cts.; oz., 40 cts. ; 1/4 1b., $81.35 ; 11 \mathrm{~b} . \ldots . . . . . .44 .00$

\section{BRUSSELS SPROUTS.}

\section{German, Kopfkohl Gruener.' French, Chou de Bruxellea.}

An almost indiepensable vegetable for winter nee. The Sprouts, resembling miniature Cabbages, are produced in the axils of the leaves. To promote a perfect growth of Sprouts, the leaves should be cut off as close ss convenient to the stock of the parent plant as the Sprouts are forming.

If by mail in $1 / 2$ lb. quantities or over, add sufficient to cover postage at the rate of 8 cents per $7 b$.

Dwarf Improved-An excellent variety, producing numerous compsct

Sprouts. Pkt., 5 cts.; oz., 15 cts.; 1/4 Ib., 40 cts.; $1 \mathrm{lb} . . . . . . . . . . . . . . .1 .50$

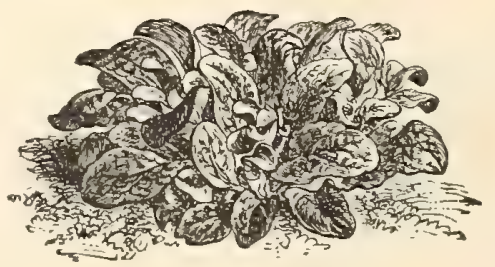

CORN SALAD, OR FETTICUS.
CORN SALAD, or FETTICUS.

German, Lammersalat. French, Mache.

Used as 8 salad. Sow early in spring in drills, or for very early use sow in fall and winter over aame as Spinach. If grown in cold frames and covered with straw mate, it can be used at any time during the winter.

If by mail in quantities of $1 / 27 b$. and upwards, postage must be added at the rate of $8 \mathrm{cts}$. per $l b$.

Pkt., 5 cts.; oz., 10 cta.; 1/4 1b., 20 cts.; 110.
BEET, SUGAR AND MANGEL WURZEL.

30 cts. ; qusrt, 60 ctв.; peck, $\$ 3.75$; bushel......................... 12.00 


\section{_urrip Bros.' Hortieultural Guide.—_ _ _ _}

\section{BEETS.}

German, Rankel Ruebe. French, Betterave.

Where a variety and choice of soll is at command, select that which is rather light for this crop. It must, however, be thoroughly enriched. As early in the apring ss the ground can be properly cultivated, lay out the drills for the seed about a foot apart and two inches deep. Sow the seed thinly. When large enough to handle, thin out the plants to about 8 or 9 inches apart.

If by mail in quantities of $1 / 27 b$. and upwards, add 8 cents per $l b$. for postage.

1 oz. to 50 feet of drill, 6 lbs. to the acre in drills.

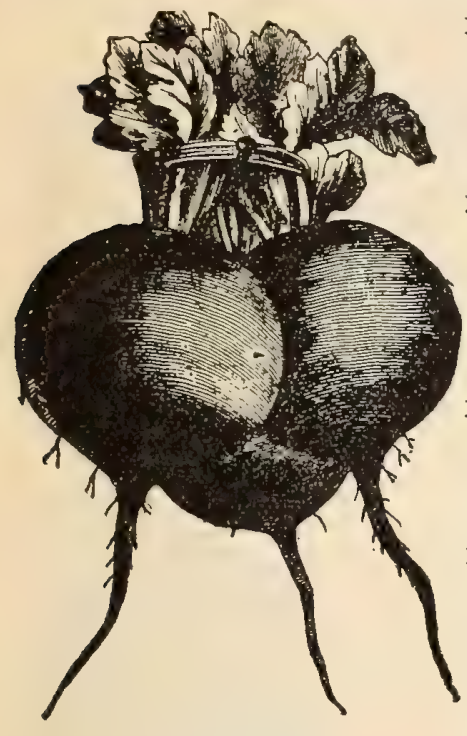

ECLIPSE-A new and valuable variety of fine quality, coming in almost as early as Egyptian. It is highly esteemed for its richness of color. Pkt., 5 cts. ; oz. ; 10 cts. ; 1/4 lb., 20 cts. ; $1 \mathrm{lb} . . . \ldots$. .60 EDMAND'S EARLY BEETAn early variety of superior quality, grows very uniform in size, with a single tep root; color, deep blood red. Pkt., 5 ct. ; oz., 10 cte.; 1// lb., 20 cts.; $1 \mathrm{lb} \ldots \ldots \ldots \ldots \ldots \ldots \ldots \ldots . . . . . . . . .60$ EGYPTIAN TURNIP - The earliest, and excellent in quality. Deep.crimson in color. Pkt., 5 cts.; oz., 10 cts.; 1/4 lb., 20 cts. ;

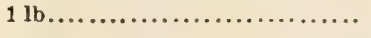

BASTIAN BLOOD TURNIP -Another very early variety, almost equal to the Egyptian in that respect. Color, a blood red. Pkt., 5 cts.; oz., 10 ets.; 1/4 lb, 15 cts.; $1 \mathrm{lb} . . . . . . \ldots \ldots . .50$ ECLIPSE BEET, DEWING'S IMPROVED BLOOD TURNIP-Very deairable for marketing; of fine form and color; very early. Plkt., 5 cte.;

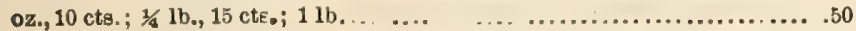

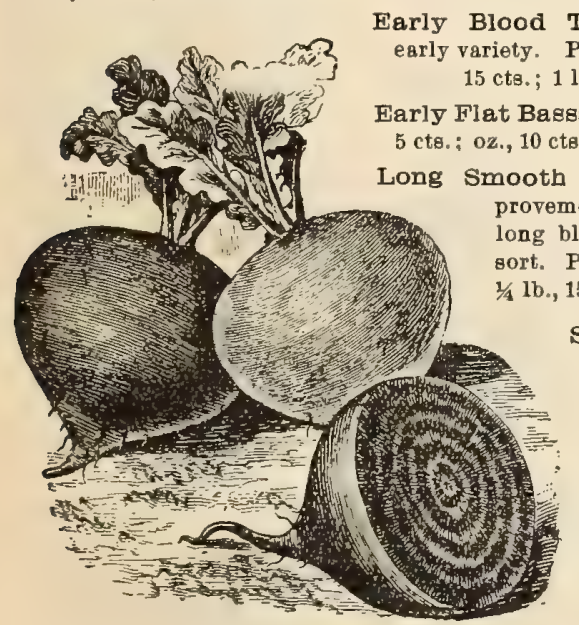

5 ctsi $;$, 10 cte;

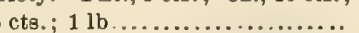

Early Flat Bassano-Very early. Pkt., 5 cts. ; oz., 10 cts.; 1/4 lb., 20 cts. ; $1 \mathrm{lb} . .$. provement on the common long blood. A valuable late sort. Pkt., 5 cts.; oz., 10 cts.; lb., 15 cte.; $11 \mathrm{~b}$.

\section{Swiss Chard, Silver or Sea-Kale Beet- For the leaves alone this variety is grown. These, with the mid- rib removed, are cooked and used as Asparagus. Pkt., 5 cts. ; oz., $10 \mathrm{cts}$; $1 / 4 \mathrm{lb}$., 20 cts.; $1 \mathrm{lb} . . . . . . . . .5$}

FDMAND'S BEET

\section{CABBAGE.}

German, Kopfkrant. . French, Chou Pomme.

Farly Cabbage Seed should be sown in February or March in hot-bede in this nelghborbood. When large enough, the plants should be transplanted into cold frames, and as early as the ground is in fit condition they should be planted In the garden, in rows about two feet apart and about eighteen inches in the row. The late varieties should be sown about the first of May and set out in the garden in July. As these grow larger than the early varieties, they should be planted in rows about three fuet apart, snd sbout two feet in the row.

If by mail in $1 / 2 l b$. quantities or over, add sufficient to cover postage at the rate of 8 cents per $l b$.

1 oz. to 1,500 plants. $1 / 2 \mathrm{lb}$. of seed in beds to transplant upon an acre.
CURRIE'S LONG KEEPING.

As the name indicates, this

variety is a good keeper, but

not only are its keeping qual

ities superior to any

other Cabbage we have

ever seen, but it is un-
surpassed for main

crop. It is short .

stemmed, beads

large, firmand

solid and of

very superior

flavor; color

d a r k-green,

with few out-

side leaves.

As a keeper it

is the best we

have ever

placed in 8

placed in 8 a

lar or pit, it

will keep in

excellent con-

dition until well

along in the fol

lowing summer.

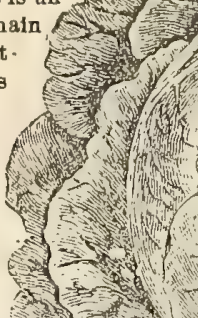

CURRIE'S ECLIPSE

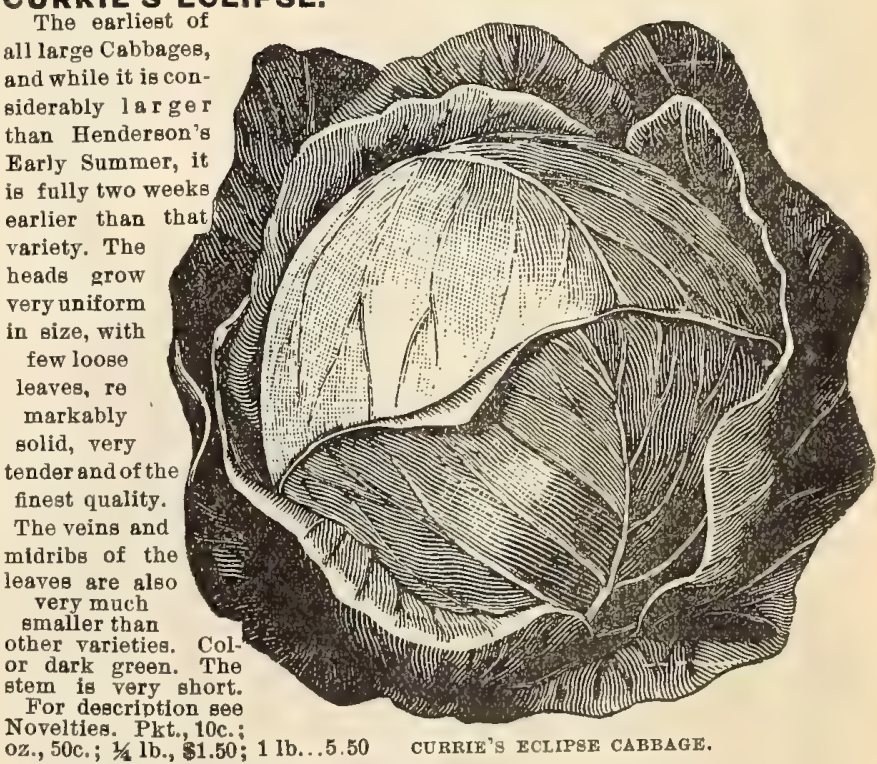

\section{CURRIE'S EARLY MARKET.}

This variety has taken a firat place among extra earlies and cannot be an passed. It is as early as Wakefield and forms a much larger head of very superior quality. For description see Novelties. 'Pkt., $1 \mathrm{Cc}$; oz., 30c; 1/4lb., \$1.25; $11 \mathrm{lb} .4 .00$ Extra Early

Etampes-The earliest Cabbage grown, wit h pointed heade of medium size firm and solid and excellent quality. Pkt., 5 cts.; oz, 15 cts.; $1 / 4$ lb., 50 cts.; 1 lb............. 1.5 EARL $Y$ JER SEY WAKEFIELD $S$ ELECT-T he variety 18 very extensively grown for an extra early. Pkt., 5 cts. ; oz., 30 cte. $1 / 4 \mathrm{lb} ., \$ 1.00 ; 1 \mathrm{lb} .3 .00$

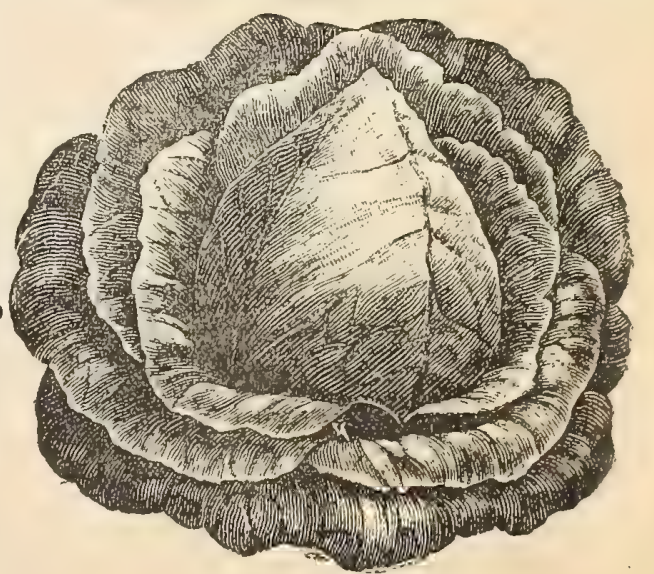

EARLY YERSEY WAKEFIELD. 


\section{0 Currie Bros.' Hortieultural Guide.}

Farly Winningstadt-One of the most popular for genergl use. Heads

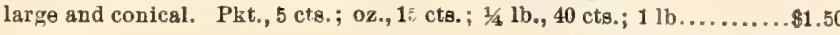

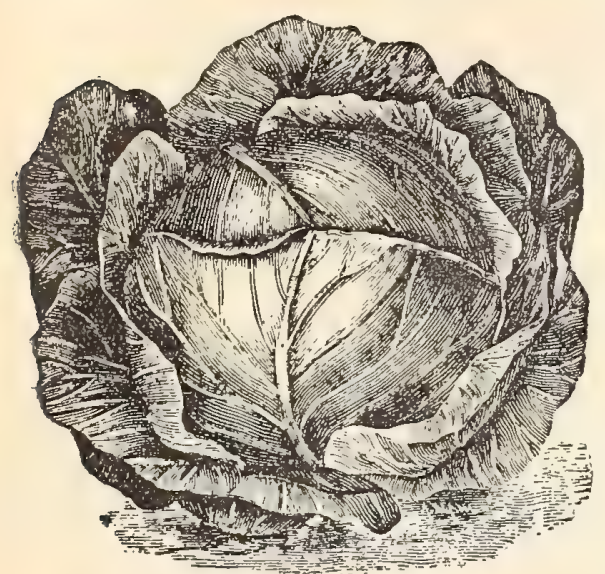

H $\theta \mathrm{nd}$ erson's Early Summer -A most excellent variety, twenty days ater than the Wakefield, but it growe to fully double the eize of the latter. Pkt., 5 cts. ; oz., 25 cts.; $1 / 4$ lb., 75 cts. ; 1 lb.......2.50

Early York-A n old favorite. Pkt., 5 cts ; oz., 15 cts.; $1 / 4$ lb., 40 cts.; 1 lb..1.35 Early Flat Dutch -A great favorite in the New Y ork market, as indeed it has bec o m e in ours. Pkt., 5 cte.; oz., 25 cts.; $1 / 4$ lb., $75 \mathrm{cts}$; $1 \mathrm{lb} . . . .2 .50$

HENDERSON'S EARLY SUMMER.

All Seasons-This variety is certainly one of the very best for all the
year round, forming a solid and compact head of very fine quality. Pkt, 5 cts.; 0z., 30 cts.; 1/4 lb., $\$ 1.00$; 1 lb

BOTTLER'S IMPROVED BRUNSWICK-A favorite variety for second, early and late planting. Pkt, 5 cts.; oz., 20 cts.; $1 / 4$ lb., $60 \mathrm{ctg}$; $11 \mathrm{lb} . .2 .25$

Fllderkraut-Resembles the Wakefield, but larger and more pointed, with few outside leaves; a second early. Grown largely for making kraut.

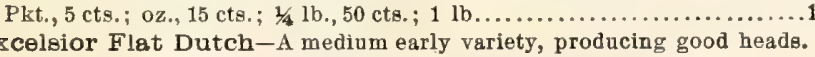

Pkt., 5 cts. ; oz., 30 cts.; 1/4 1b., $\$ 1.00 ; 1$ lb............................ 00

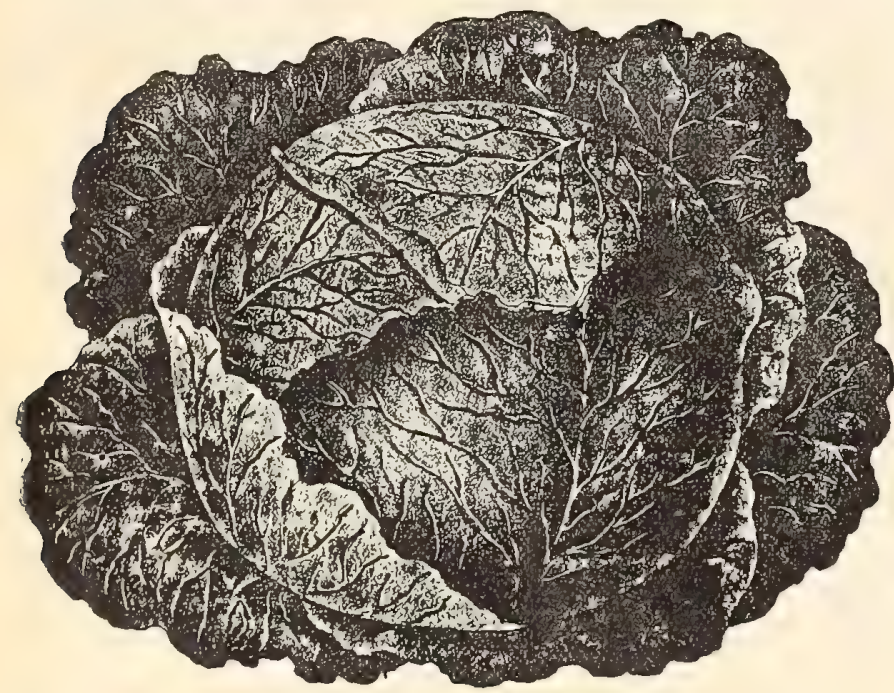

CURRIE'S SELECTED PREMIUM FLAT DUTCH CABBAGE

CORRIE'S SELECTED PREMIUM FLAT DUTCH-After careful selection we have obtained a first-class strain of this favorite variety. (See cut.) Pkt., 5 cts. ; oz., 25 cts.; $1 / 4 \mathrm{lb}, 75 \mathrm{cts} . ; 11 \mathrm{~b}$.

Sure Head-One of the best main crop Cabbsges. Pkt., 5 cts. ; oz., 25 cte. : $1 / 4$ lb., 85 cte.; 1 lb.

Stone-Magon-A variety of the Mason Drumhead, but a decided improvement; very sweet and tender. Pkt., 5 cts. ; oz., 25 cts.; 1/4 lb., 40 cts. ; 1 lb. 2.50 Large Late Drumbead-Heade very large, round and solid. Pkt., 5 cte.; oz, 15 cts.; $1 / 1$ lb., 40 cte, ; 1 lb.

MARBLEGEAD MAMMOTH DRUMHEAD-The largest Cabbage grown. It is no uncommon occarrence to find a head welghing from 50 to 60 lbs. Pkt., 5 cts.; oz., 15 cts. : 1/4 lb., 60 cts.; 1 lb.....................2.00

FARLY DWARF ULM SAVOY-A dwarf variety, very early and very eweet and tender. Pkt., 5 cte.; oz., 20 cts. : $1 / 4$ lb., 60 cts.; $1 \mathrm{lb} . . . . . . . . .2 .0$
rumbead Sevoy-An excellent variety, of fine davor; heads large and ohowy. Pkt., 5 cts.; oz., 20 cts. ; 1/4 lb., 60 cts. ; 1 lb..................... 00

IARGE RED PICKLING-(Improved)-Pkt., 5 cts.; oz., 20 cts.; $1 / 41 \mathrm{~b}$. , $60 \mathrm{cts}$; $1 \mathrm{lb}$

EARLY BLOOD-RED ERFURT-Earlier and gmaller than the large red; valuable for pickling. Pkt., 5 cts.; oz., 25 cts.; 1/4 lb., 75 cts.; 1 lb.. 2.50

\section{CARROT.}

German, Moehre. French, Carote.

For the succeseful cultivation of this root the soil should be light (sandy soil is beet) and deeply tilled. For an early crop the seed should be sown as early as the ground can be properly worked. For later crops it may be sown any time until about the middle of June. Sow in rows about 15 inches apart. The seed can be best sown by mixing it in moist sand. Keep down weeds. Thin out young plants as soon as they can be handled, leaving them about four inches apart.

If by mail in $1 / 2$ lb. quantities or over, add sufficient to cover postage at the rate of $8 \mathrm{cts}$. per. $2 b$.

$1 \mathrm{oz}$. to 150 feet of drill. 3 to $4 \mathrm{lbs}$. per acre in drills.

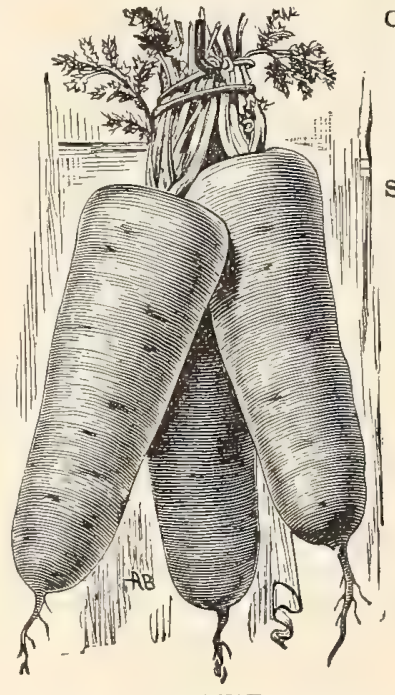

CHANTENAY-A half-long stump rooted variety, resembling the old half-long Nantes variety in appearance, but making a thicker root, and is much more productive and of superior quality. Pkt, 5 cts. ; $0 z_{.}, 10$ cts. ; $1 / 4$ lb., 25 cts.; $1 \mathrm{lb} \ldots \ldots \ldots \ldots . .85$ ST. VALLERY-A medium long sort, tapering gradually snd evenly from the shoulder, which averages 3 inches in diameter. It is smooth and of a bright color, tender, sweet and very productive. Pkt., 5 cts.; oz., 10 cts.; $1 / 4$ lb., 25 cts. ; $11 \mathrm{lb} .85$

Early French Forcing--A valuable forcing variety, with short, stubby roots. Pkt., 5 ctg. ; oz., 15 cts. ; 1/4 lb., 30 cts. ; 1 lb. ........1.00

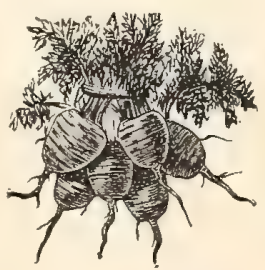

\section{EARLY FRENCH} FORCING.

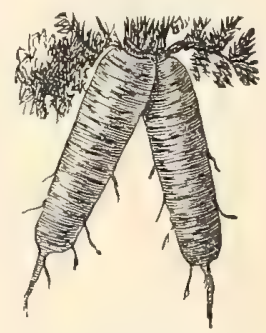

SCARLET HORN,

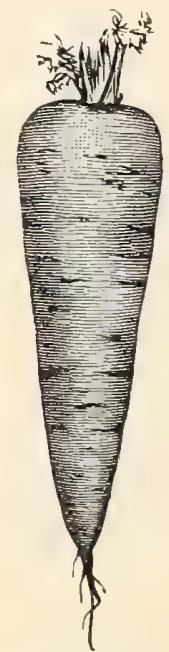

DANVERS,

Early Scarlet Horn-Largely grown for early ues; one of the best. Pkt., 5 cts, ; oz., 10 cts.; $1 / 4$ 1b., 25 cts.; $1 \mathrm{lb}$

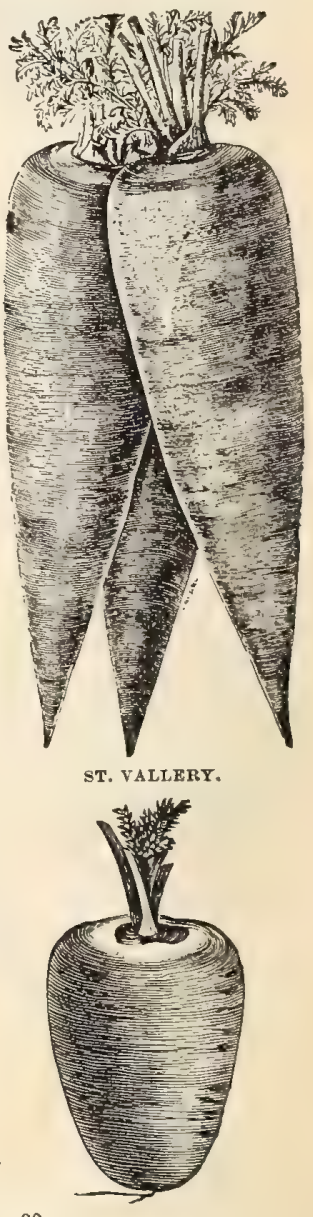

90 OX HEART.

DANVERS-No variety will produce so much to the acre, with a minimum length of root, $8 \mathrm{~s}$ this one. It is of medium length, heavy at the neck, and quite smooth; color, a rich orenge. Pkt., 5 cte.; oz., 10 cte.; $1 / 4 \mathrm{lb}$., 25 cte. ; 1 lb.

GUERANDE, OR OX BEART-A variety with short, thick roots, the dismeter often exceeding the length. Color, bright orange; aweet and fine grained; good for table or stock. Pkt., 5 cts.; oz., 10 cts.; $₹$ lb., 30

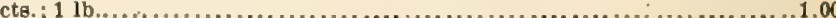
Half-Long Scarlet Carentan-A good early variety, auitable for forcing; color, deep orange. Almost without core. Pkt., 5 cte.; oz., 10 cts. ;

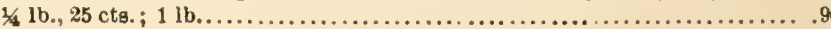




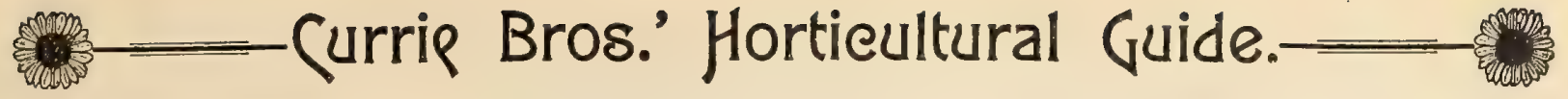

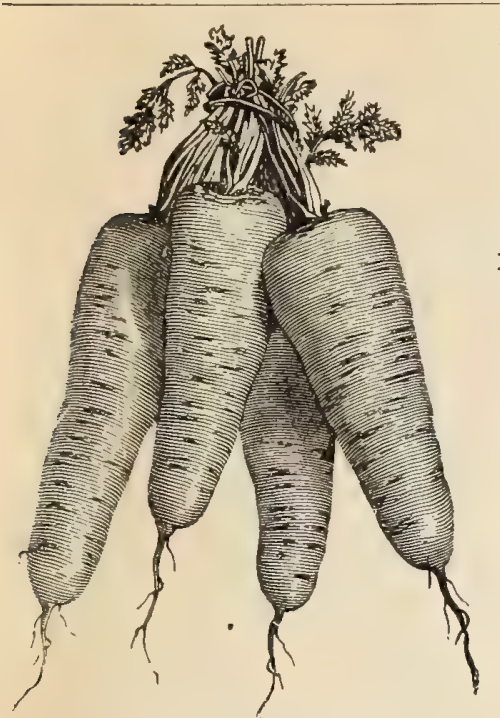

HALF-LONG STUMP ROOT CARROT.

Altringham - A large-growing variety, of fine flavor. Simflar to long Orange, but of a bright color. Pkt., 5 cte.; oz., 10 cts.; $1 / 4$ lb., 20 cts.; 1 lb. .65 LONG ORANGE IMPROVED-A large-growing favorite variety: may be grown in the garden or $8 \mathrm{~s}$ a field crop. Pkt., $5 \mathrm{c} ; 0 \mathrm{oz}$., $10 \mathrm{c} ; 1 / 4 \mathrm{lb}$., $20 \mathrm{c} ; 1 \mathrm{lb}, .65$

Large White Belgian Carrot--This variety is feeding stock. Pkt., 5c; oz., $10 \mathrm{c} ; 1 / 4 \mathrm{lb}$., $20 \mathrm{c} ; 1 \mathrm{lb} .$.

\section{CAULIFLOWER.}

\section{German, Blumenkohl. French, Choufleur.}

As recommended in Cabbage culture, the seed should be sown in February or March in a hot bed, transplanting the plants when large enough into another or the same frame, and gradually hardening them off, preparatory to planting thoroughly cultivated and made very rich by manuring good garden soil, if attention in the matter of watering, destroying insecte, and thorough cultivation, will be repaid.

If by mail in $1 / 2$ lb. quantities to cover postage at the pound.

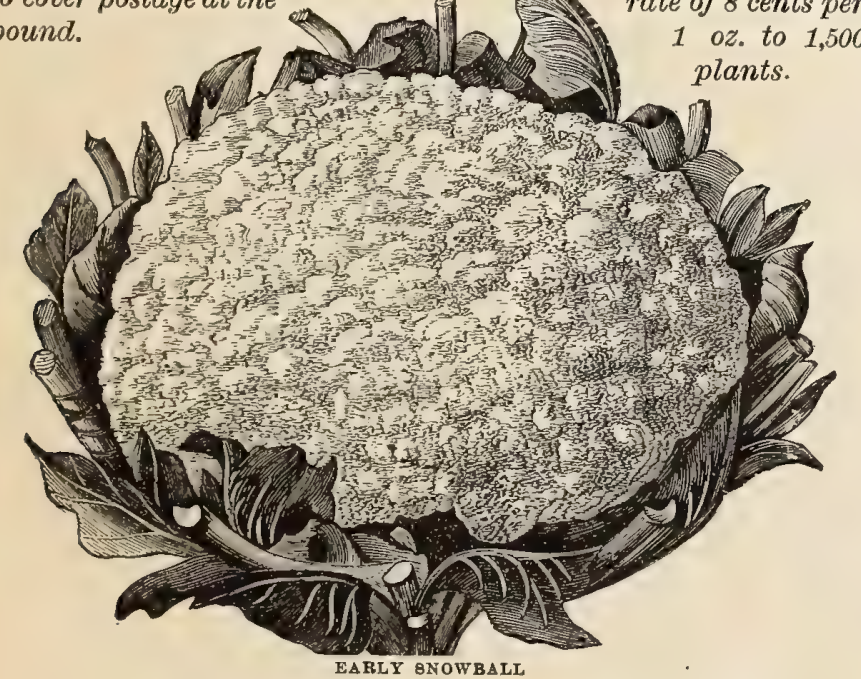

IMPORTED EXTRA SELECTED EARLY DWARF ERFURTSee Novelty List. Pkt., 25 cts.; 0z., $\$ 400 ;(1 / 4$ oz. at oz. rstes); $1 / 4 \mathrm{lb} \ldots . . \$ 14.00$

EARLY SNOWBALL-1Extra Selected)-Grown for as by one of the most relisble growers in Europe, who exercises grest care in selectin only the finest speclmen heade and keeping the seed pure. Pkt., 25 cts.

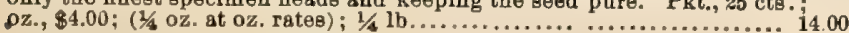

Extra Early Dwarf Erfurt-A very fine market variety; produce heads large and compact, of good color andiquality. Pkt., 15 cts.; oz.,

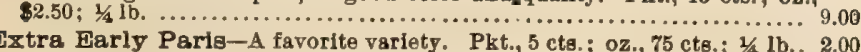
Extra Early London-Similar to fthe preceding variety. Pkt., 5 cts.; LENORMAND'S SHORT STEMMED - A late variety of superior quality; heads large and well formed. Pkt., 5 cte.; oz., $55 \mathrm{cts}$; $1 / 61 \mathrm{~b} . .2 .00$

\section{CELERY.}

Although a few gardeners continue to cultivate this vegetable on the olo plan, the only one practiced years ago, ite cultivation bas undergone a grea reformation of late years. Very little of the seed fs now sown in hot-bede, but instead is sow $n$ in a cold frame or even out in the open air, early in April, and in June and July is transplanted where it is intended to mature. The young plante, before transplanting, should be clipped down partially two or three times to promote a stubby growth. On the ground, previouely thoroughly enriched and cultivated, lay out lines 3 feet apart, on the surface, not in trenches, 8.8 ueed to be planted. Plant the plants in these rows about 6 inches apart. Until about the middle of August the only work to be done is frequent ultivation and watering in dry weather Earthing up may then begin, and continue as long as the plants grow, to bleach the stems and $r \in n d e r$ them criep.

If by mail in $1 / 2$ lb. quantities or over, add sufficient to cover postage at the rate of 8 cts. per 76.

1 oz. to 3,000 plants.

GOLDEN SELF-

BLANCH I N G

-Like the White

Plume, this Celery requires very little earthing up, and in $m$ any other respects it

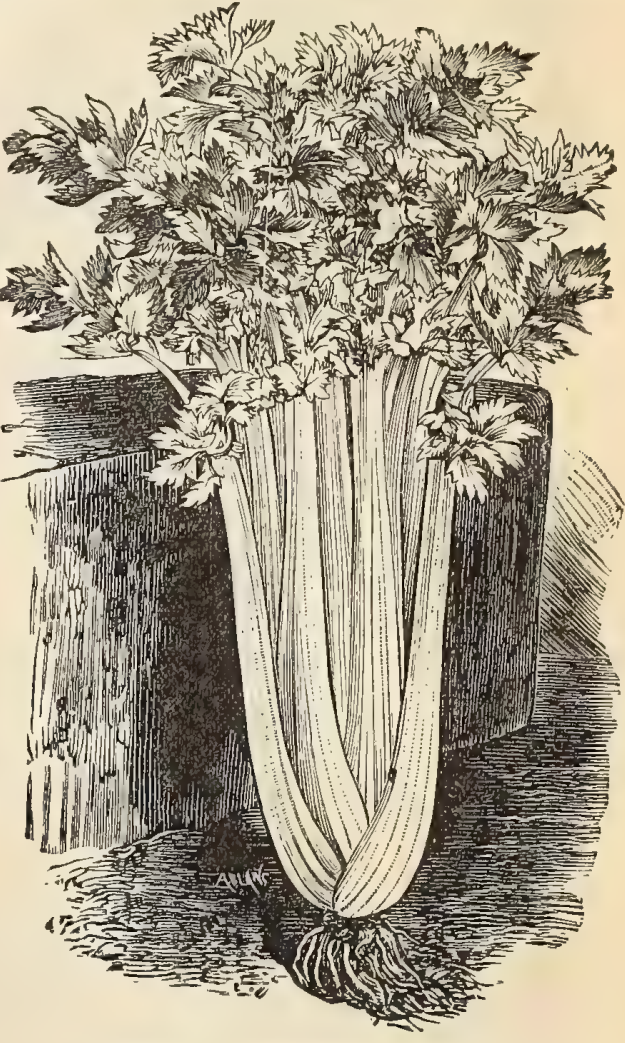

GOLDEN 8ELF-BLANCHING CELERY. is aimilar to that favorite sort, differing, however, in color, which is yel lowish, the heart being large and solid, and of beautiful golden hue Pkt., 5 cts.; oz, 35 cts. ; $1 / 4$ lb., $\$ 1.00 ; 1$ lb......................... $\$ 3.50$

GIANT GOLDEN HEART-The market gardener will find in this a most desirable sort. Its rich golden color alone would suffice as a recommendation, but it has the additional merits of aize, excellent quality, crispness and very fine flavor. Pkt, 5 cts.; oz., 35 cts.; $1 / 4$ lb., 85 cts. ; 1 lb.3.00

WHITE PLUME-Unlike most varieties, this one does not require to be earthed up, but if only loosely tied, or a few handfuls of earth brought close around the base of the leaves to keep them close together, all the inner leaves or thin stalks will turn white and crisp. Pkt., 5 cts.; oz, 30 cts. $1 / 4 \mathrm{lb} ., \$ 1.00 ; 1 \mathrm{lb}$

GIANT PASCAL-A selection from the Golden Self Blanching, possess ing all the good qualities of that variety, but much larger and a better keeper. Pkt., 10 cts.; oz., 50 cts. ; $1 / 4$ lb., 75 cts.; 1 lb................6.00

HENDERSON'S HALF DWARF-A leading market variety, of medium growth, excellent in quality and a good keeper. Pkt., 5 cts.; oz., 25

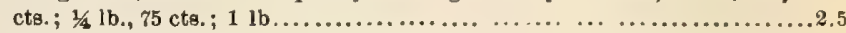

GOLDEN DWARE-Waxy golden yellow when fully blanched, Crisp, solid, and of excellent flavor. As a keeper in winter it has no superior.

Dwarf White Solld-One of the best keepers grown; solid and crisp, and of euperior quality; habit of plant compact. Pkt., 5 cts.; oz., 20 cts. $1 / 4 \mathrm{lb} ., 60 \mathrm{cts}$; $1 \mathrm{lb}$

BOSTON MARKET-Dwarf in habit, white atemmed, flavor excellent; a good keeper. Pkt., 5 cts. ; oz., 25 cts.; $1 / 41$ 1b., 75 cts.; 1 lb................ .2.40 NFW ROSE-Color, a beantiful rose shade of very fine flavor, crisp and solid. Pkt., 5 cts.; oz., 35 cts. ; $\times 1$ b., $\$ 1.00 ; 1 \mathrm{lb} \ldots . . . \ldots \ldots . . . . . .3 .50$ Sandringham Dwarf White-A well-known and very guperior variety, of fine flavor and firm texture. Pkt., 5 cte.; oz., 20 cts.; $1 / 4$ lb., 60 cts.; 11 lb.2.00

White Walnut-An excellent Celery for table use, its feathery folisge, when nicely blanched having 'a besutiful appesrance. Pkt, 5 ctø.; oz., 25 cts. : $1 / 4$ Ib., 70 cts. : $1 \mathrm{lb}$.

LONDON RED-A most excellent variety. Like the majority of red Celeries, it is criep and of fine flavor, and an excellent keeper. Pkt., 5 cts.;

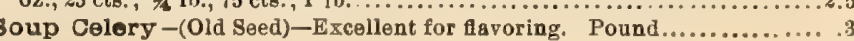




\section{2 -Currie Bros.' Hortieultural Guide.}

\section{CELERIAC-Turnip-Rooted Celery.}

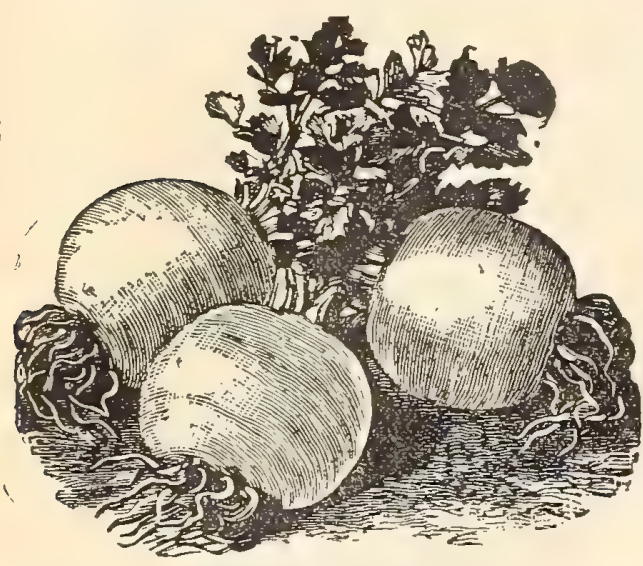

A variety of Celery having Turnipshaped roots, which, when cooked and sliced and used with vinegar, makes a most excellent aradad. It is more hardy and may be treated arme as Celery.

Large Erfurt -

Pkt., 5 cts.; oz.,

$15 \mathrm{cts} ; 1 / 4 \mathrm{lb} ., 40$ ARGE SMOOTH $P R A G U E$ CELER I AC. This is the largest and beat vari-

ety grown, round in shape, smooth,

with few side roots. Pkt., 5 cts.; oz., 25 cts.; $1 \frac{1}{4} 1 \mathrm{lb}_{4}, 75$ cts.; $1 \mathrm{lb} . \ldots . . . . . .2 .00$

\section{CORN-Sweet.}

\section{German, Welschkorn. French, Mais.}

Sow in rows four and a half feet apart, or plant in hills, if in rich aoil, a distance of about four feet each way. If the soil is poor and the variety dwarf, the distance apart may be lessened. Begin planting in May and continue until the last week in July.

If by mail in quantities of a pint and upwards, add 10 cts. per quart for postage. One quart to 200 hills; 8 to 10 quarts to the acre, in hills.

CORY - For several years this has been the favorite early sweet Corn with market gardeners. It is dwarf in habit, and the ears, which are of fair market size, are set low, each stalk usnally producing two or three good ears. Pkt., 5 cts.; pint, 10 cts.; quart, 20 cts.; peck, $\$ 1$; bushel ......... $\$ 3.50$

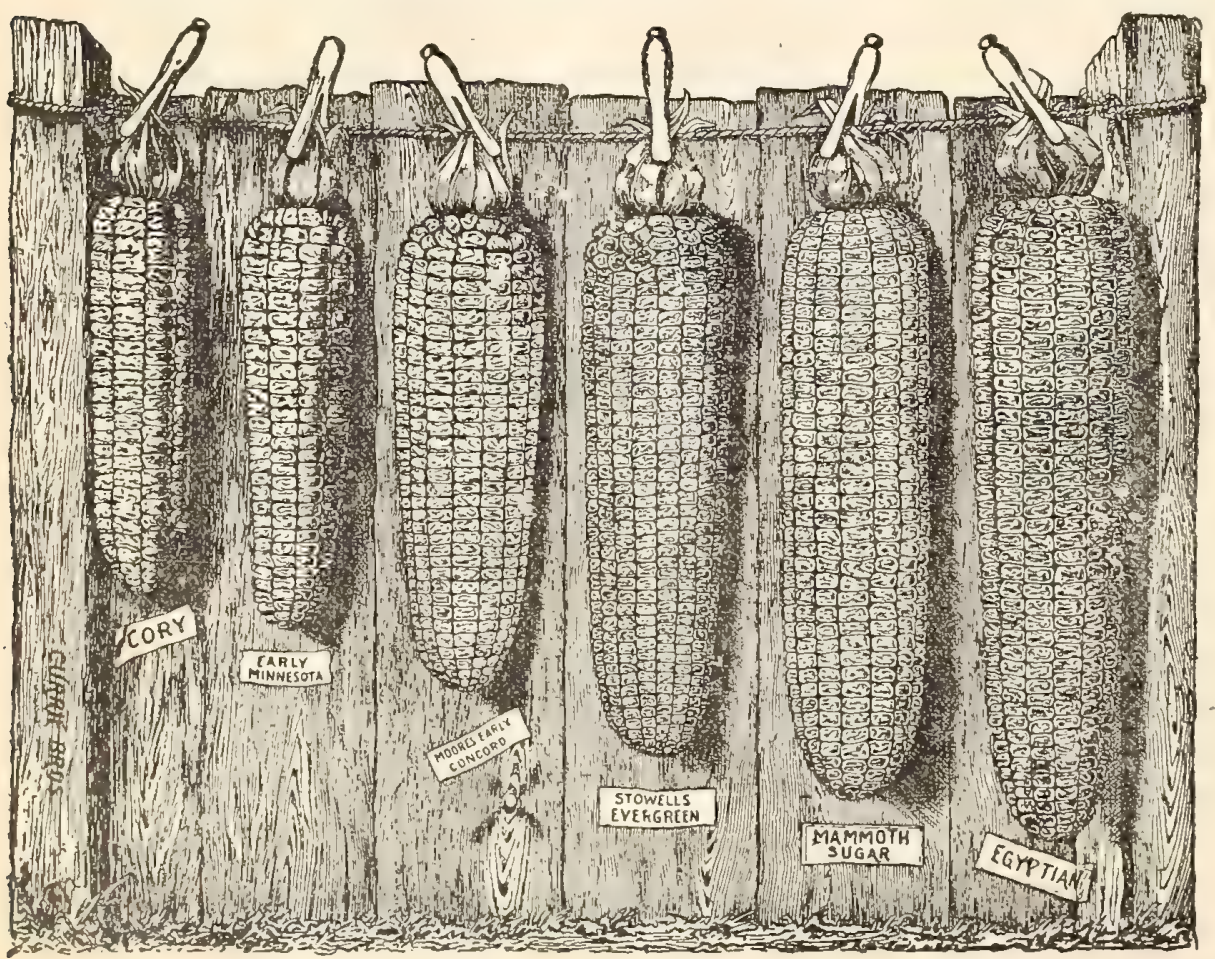
bughel. 85 cts, ; buehel.

PERRY'S HYBRID-A large early variety, coming into uee a few days later than Marblehead. The stalk grows abont ofx feet high and each stalk produces two perfect ears. Pkt., 5 cts. ; pint, 10 cts.; quart, 20 cts.; peck, 85 cts, ; bushel.......................................\$3.00

CROSBY'S EARLY-A favorite market variety; ears of medium size. Pkt., 5 cts. ; pint, 10 cts. ; quart, 20 cte.; peck, 85 cts.; bushel..............3.00 MOORE'S EARLY CONCORD-A very fine variety with large ears. Pkt., 5 cts. ; pint, 10 cts.; quart, 20 cts. ; peck, 85 cts.; bushel.............. 3.00

HICKOX IMPROVED-A medium early variety of fine quality. Valuable for canning. Pkt., 5 cts. ; pint, 10 cts. ; quart, 20 cts.; peck, 85 cts. bushel.................................................... 3.00

MEXICAN BLACK-One of the most desirahle for family use. Very tender and swest. Pkt., 5 cts.; pint, 10 cts.; quart, $20 \mathrm{cts}$; peck, $90 \mathrm{cts.;}$

EGYPTIAN-A favorite variety, with large-sized ears, of very fine flavor. like all large sorts, it matures late. Pkt., 5 cts.; pint, 10 cts.; quart,

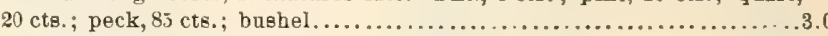

POTTER'S EXCELSIOR, or SQUANTUM-An excellent variety with fine large ears and deep grain; early. Pkt., 5 cts.; pint, $10 \mathrm{cts.}$ quart, 20 cts.; peck, 85 cts.; bushel ................................

OLD COLONY - An exceedingly productive and very sweet variety, averaging three ears to a stalk. Pkt., 5 cts ; pint, 10 cts. ; quart, 20 cts. ; peck,

3.00

AMBER CREAM-A medium early variety; ears large and very sweet, and when ready for table use very white. When ripe the kernels are a beartiful amber shade. Pkt., 5 cts.; pint, 10 cts.; quart, $20 \mathrm{cts}$, ; peck, 85 cts.; bushel............................................... 3.00

ASYLUM-A large late variety, of auperior quality. Pkt., 5 cte.; pint, 10 cts.; quart, 20 cts.; peck, 85 cts. ; bushel............................3.00

New England Eight-Rowed-An early variety of superior quality, bearing very large ears. Pkt., 5 cts.; pint, 10 cts.; quart, 20 cto. ; peck, 85 cts.; bushel............................................. 3.00

STABLERS' EXTRA EARLY-A large early sort, coming into use about the same time as Marblehead. It is a good market variety; very sweet. Pkt., 5 cte.; pint, 10 cts.; quart, 20 cts.: peck, $\$ 1.00$; bushel....... 3.50 STABLERS' PEDIGREE-An excellent sort for main crop, coming into uee earlier than Stowell's Evergreen, and is superior to that variety in sweetness. It usually besis two good-sized ears to the stalk. Pkt., 5 cts.; pint, 10 cts.; quart, $20 \mathrm{cts}$; peck, 85 cts . ; bushel...........3.00 NE PLUS ULTRA (Shoe Peg)-A very prolific Corn, sometimes bearing four small eurs to a stalk; is a medium lute variety, and of good quality. Pkt, 5 cte.; pint, 10 cte.; quart, 20 cte.; peck, $\$ 1.00$ cte.; bushel. 3.50 GOLD COIN-An excelient main crop Corn, remaining a long time in the green state; color golden yellow, very sweet and prolific. Pkt., 5 cts.; pint, 10 cts.; quart, 20 cts. peck, $\$ 1.00$; bushel .....................4.00 STOWELL'S EVERGREWN-An excellent late variety, remaining longer in the green atate than any other variety; ears large. Pkt., 5 cts.; pint, 10 cts. ; quart, 20 cts.; peck, 85 cts. ; bushel...................3.00 MAMMOTH SUGAR-A late variety, with very large ears of fine quality. Pkt,, 5 cts.; pint, $10 \mathrm{cts.;}$ quart, 20 cte.; peck, 85 cts.; bushel ............................. 3.00 CORN-Field.

(See Farm Seed Department, page 29.)

\section{POP-CORN.}

Queen's Golden-Ears large and very proJicic. ' Pkt., 5 cts.; pint, 15 cts.; quart........ .30 Silver Lace-As the name implies, is of a beautiful: traneparent color; very prolific. Pkt., 5 cte. ; pint, 15 cts.; quart............ . s

\section{CHERVIL.}

German, Gartenkerbel. French, Cerfeuil.

Marblehead-Similar to Cory, but abont ten days later. The grain is red when dry Pkt, 5 cts.; pint, 10 cts. ; quart, 20 cts.; peck, 85 cts.; bushel . .3.00 CHICAGO MAREET, or BALLARD'S-An excellent twelve-rowed variety, maturing about ten days later than Cory. Pkt, 5 cts.; pint, 10 cts. quart, $20 \mathrm{cts}$,; peck, 85 cts.; bushel

EARLY MINNESOTA-One of the best of the early varieties, with fairsized ears, plant dwarf. Pkt., 5 cts.; pint, 10 cte.; quart, 20 cts. ; peck, 85 cts.; bushel.
If by mail in quantities of $1 / 276$. and upwards, postage mist be added at the rate of 8 cts. per $7 b$

Curled-The young lesves are used in soups and salads. Sow in May, in drills half an inch deep. Pkt., 5 cts.; oz., 10 cts.; $1 / 4$ lb., 40 cts.; 1 lb.... 1.20

\section{DANDELION.}

Broad Leaved-Pkt., 5 cts.; oz., 20 cts.; 1 / lb., 7 . cts.; 1 lb............2.50 


\section{Currie Bros." Hortieultural Guide.-_—}

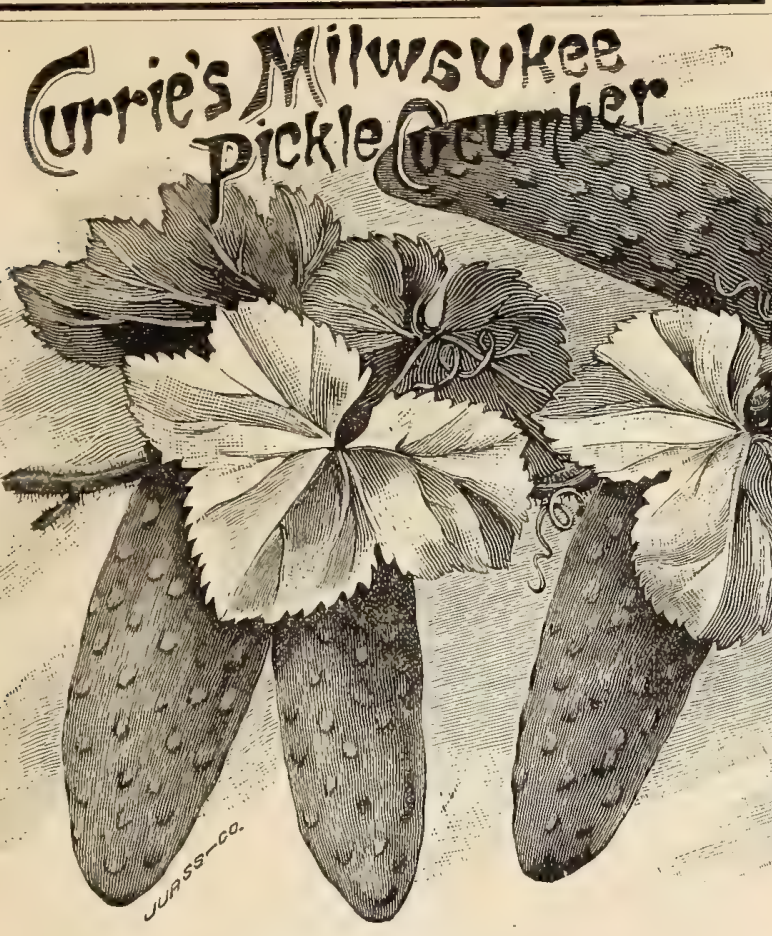

\section{CUCUMBERS.}

German, Gurke. French, Concombre.

Plant in hills four feet apart, in:well-prepared warm, ricb, loamy soil. Mix a shovelful of well-rotted manure in each hill. The fruit shou'd be picked when large enough, whether they are wanted or not, as it cest: 0 je the vitality of the vine if left to ripen.

If by mail in quantities of $1 / 2$ lb. and upuards, postage must be added at the rate of 8 cents per $7 b$.

$1 \mathrm{oz}$. to:50 hills, 2 lbs. to the acre in hills.

CURRIE'S MILWAUKEE PICKLE-This variety has been proved withont doubt the best pickling Cucumber in caltiration. For productiveness it is unequaled, and the quality of the fruit is the very best. We cannot speak too highly of its merits, and judging from the numerous letters we have received in its praise, its fance has become wide-sp: ead. One letter we have before us speaks of getting three barrele of emall pickles from a 5-ct. package of seed. Pkt., 5 cts.; oz., 15 ets.; 1/4 lb.,

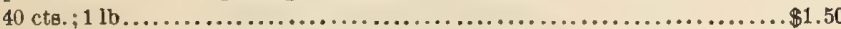

EXTRA EARLY GREEN PROLIFIC-A variety similar to the old Green Prolific, but about two weeks earlier. Pkt., 5 cte.; oz., 10 cte.; 1/4

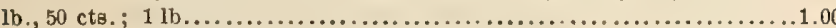

IMPROVED EARLY WHITE SPINE-A favorite early variety; very productive and tender; fine for table use. Pkt., 5 cts.; oz., 10 cts.; $1 / 4$ 1b., $20 \mathrm{cts}$; $1 \mathrm{lb}$....

EVERGREEN WHITE SPINE-A variety similar to the Extra Long, but remaining green until fully matured. Pkt., 5 cts.; oz., 10 cts. ; $1 / 4 \mathrm{lb}$., $25 \mathrm{cts}$; $1 \mathrm{lb}$.....

PEERLESS WHITE SPINE-A very fine strain of White Spine, fruit straight and well formed, keeping its color until late. Pkt., 5 cts.; oz., $10 \mathrm{cts}$; $1 / 2 \mathrm{lb}$., $25 \mathrm{cts}$; $1 \mathrm{lb}$.

TMPROVED IXTRA LONG WHITE SPINE-A large variety of White Spine; largely used for forcing by market gardeners. Pkt., 5 cts. oz., 10 cts.; $1 / 4 \mathrm{lb}$., 25 cts. ; $1 \mathrm{lb}$.

IMPROVED "LONG GREEN-A fine variety for pickles; very pro-

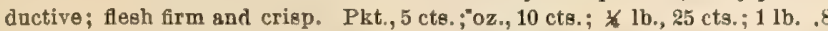

Early Cluster-An early variety producing its; fruit in clusters; very productive. Pkt., 5 cto. ; oz., 10 cts. : $1 / 4 \mathrm{lb}$., 20 cts.; 1 lb.....................

BOSTON PICKLING - Very productive and of superior quality. Pkt., 5

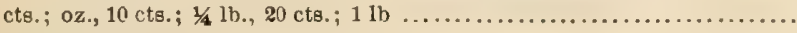

Long Green Turkey-An excellent variety. Good either for pickling or slicing, dark green, flesb firm and solid. Pkt., 5 cts.; oz., 10 cts.; $\nsucc$ lb.,

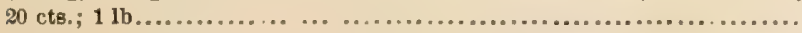

TARLY FRAME, SHORT GREEN, or GHERKIN-An excellent variety for pickles when young. Pkt., 5c.; oz., 10c.; 1/4 lb, 20c.; $1 \mathrm{lb} \ldots . .65$ NICHOL'S MEDIUM GREEN-An excellent variety; color, dark green; of medium eize and very productive. Always etraight and emooth. Pkt, 5 cts.; oz., 10 cts.; $1 / 4$ lb., 25 cte.; $1 \mathrm{lb}$................................ .

GREEN PROLIFIC-One of the best pickling sorts; very productive. Pkt., 5 cts.; oz., 10 cts.; 1/4 1b., 20 cts.; 1 lb
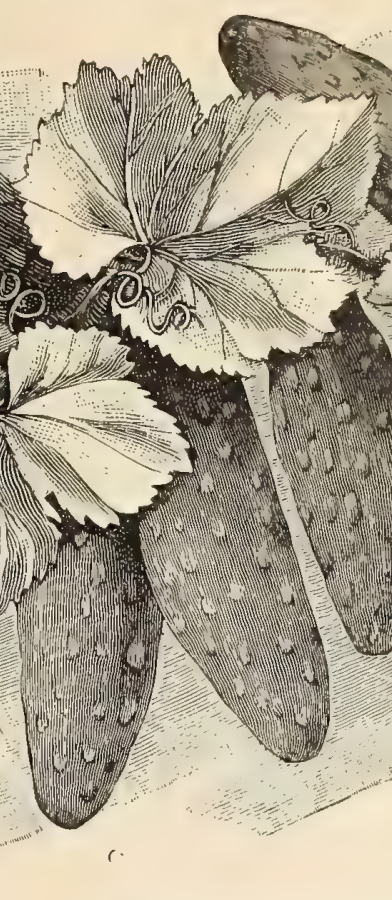

West India Gherkin, or Burr-Used exTAILBY'S HYBRID-A good variety for family use. Pkt., 5 cti.; oz.,

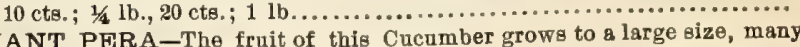
GIANT PERA-The fruit of this Cucumber grows to a large size, many of them from 15 to 18 inches in length, smooth and straight. The flesh is clear white, very crisp and tender, making it a valuable slicing variety.

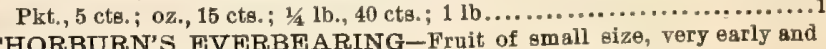
very productive. Pkt., 5 cts.; oz , 15 cts.; $1 / 4$ lb., 40 cts.; $1 \mathrm{lb} . . . . . . . . .1 .50$

Write for special prices on large quantities of Cucumbers.

ENGLISH FRAME OR FORCING VARIETIES.

Sow in hot-bed in January, February or Marchi, End kep in a temperature of 65 to 70 degrees. Artificial impregnation of the flowers is necessary when grown under glase.

Model Cucumber-The handsomest frame Cucumber we have ever seen. It grows to a very large size, often messuring 24 inches in length. The quality is the best, exceedingly crisp and tender. When sliced and served with vinegar it is uhautpassed in flavor. It is a vigorous grower and very

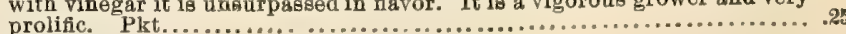
Tolegraph-Pkt Marquis of Lorne-Pkt. .25 CRESS, or PEPPER-GRASS.

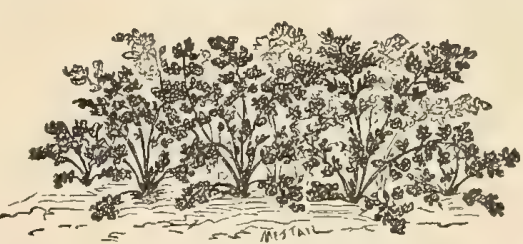

German, Kresse

French, Crēê̊̊n.

A favorite pungent arlad Sow thickly at frequent interals, to keep up a succession, sit soon runs to seed.

If by mail in quantities of $1 / 2 l b$. and $u p$ wards, postage must be added at the rate of 8 cents per $7 b$.

Extra Curled-Very fine. Pkt., 5 cts.; oz., 10 cts.; 1/4 1b., 15 cts.. 1 lb.... .35 Upland Cress-(Barbarea Vulgaris). This vegetable in many respects resembles the Water Cress, having the same agreesble and highly-prized flavor. Sow the seed in April or May in thls latitude, in rows 12 to 15

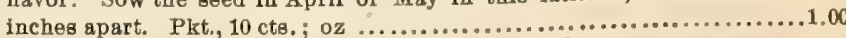

\section{CRESS-Water. \\ German, Brunnenkresse. Freach, Cresson de Fontaine.}

A well-known aquatic plant to be found growing in great abundance along the margins of running streams and ponds. It has a very plessant pungent taste.

If by mail in quantities of $1 / 2 \mathrm{lb}$. and

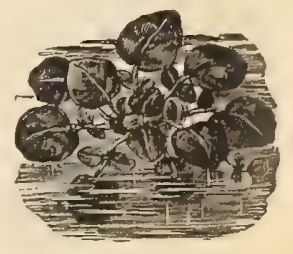
upwards, postage must be added at the rate of 8 cents per $l b$.

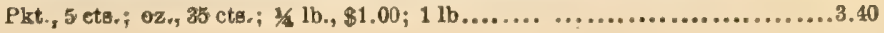




\section{Currip Bros.' Hortieultural Guide}

\section{LETTUCE.}

German, Lattich. French, Laitue.

The Lettnce is universally grown by all those who bave gardens. It is of easy growth and will thrive in any ordinary garden soil. Sow thinly in rows one foot apart, and when large enough thin out the plante so as to leave room for growth.

If by mail in quantities of $1 / 2$ lb. or upwards, postage must be added at the rate of $8 \mathrm{cts}$. per $l b$.

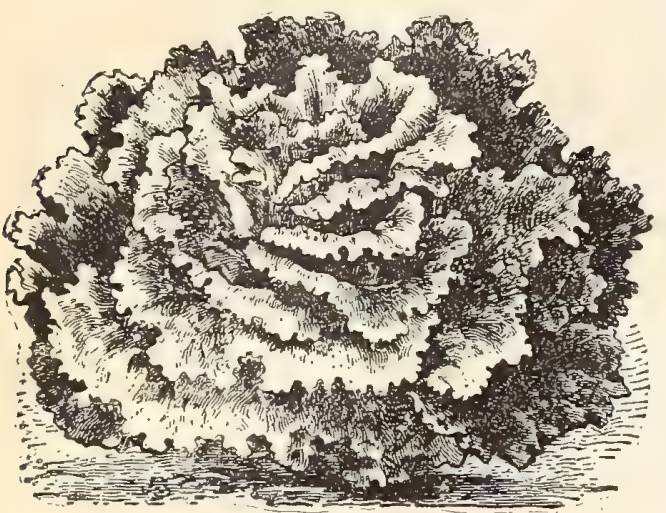

Early Curled

Simpson-

This variety

does not head,

but form a

compact, close

mass of leaves.

Pkt., 5 cts.

oz., $10 \mathrm{cts}$; $1 / 4$

lb., 30 cts.; 1

BLACK SEED-

ED S I M P-

SON-The

main forcing

variety in this

section; it does

not head but

forms a com

pact mass of

leaves, and differs in being lighter colored; stands the summer heat well, and is nearly double the size of the Carled Simpson. Pkt., 5 cts.; oz., 10 cts.; $1 / 3$ lb., 30 cts.; 1 Ib

THE DEACON-Forms a very large solid head, very crisp and tender: keepe well during the hot summer months. Pkt., 5 cts.; oz., 10 cts.; 7

DENVER MARKET-An excellent forcing variety, color light green,

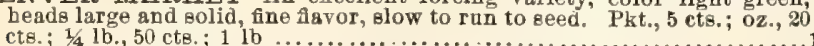

ST. LOUIS BUTTER-A favorite Market Gardenera" variety. Forms a Iarge solid head, is very crisp and tender and withstands the summer heat admirably. Pkt, 5 cts.; oz., $10 \mathrm{cts}$; $1 / 1 / 4$ lb., 30 cts.; $1 \mathrm{lb}$

GRAND RAPIDS-A desirable forcing Lettuce; very crisp and tender and keeps a long time from wilting when cut. It is also a good open

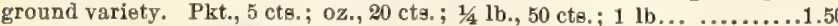

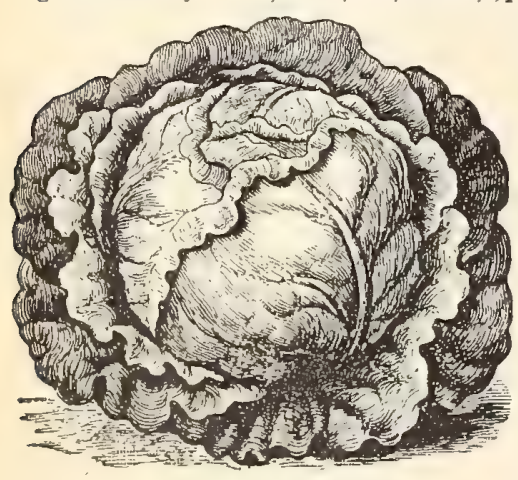

DEFIANCE LETTUCE.
Large White $\mathrm{s} u \mathrm{~m} m \boldsymbol{m}$ Cabbage-A good summer variety; heads of good size, close and well formed. Pkt., 5 cts. ; oz., 10 cts.; $1 / 4$ lb., 30 cts.; $1 \mathrm{lb}$

1.00

YELLOW SEEDED BUTTER-A very distinct eort, forming a large, dense, yellow hesd, very crisp and tender, and excellent in flavor. Pkt., 5 cts.; oz., 10 ctø.; 1 lb., 30 cts.; 1 lb............1.00 DEFIANUE-This variety as a long-keeping sort is unexcelled. It forme a good head, and remains crisp and tender throughout the entire sesson.

The leaves are a beautiful light green co or. Pkt., 5 cts.; oz., 10 cts.; 1/4 lb., 30 cts.; 1 lb

BOSTON MARKET-A superb variety; growa very compact, and is beautifully white and crisp. Pkt., 5 cts. ; oz., 10 cts. ; 1/4 1b., 30 cts.; 1 lb.... 1.00

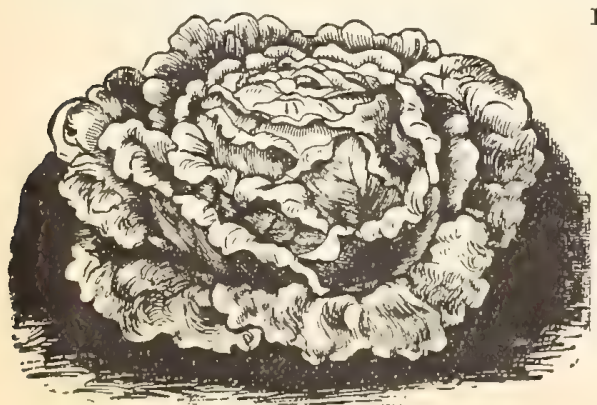

BUTTERCUP-A new early variety forming solid heads of remark a ble tendernesa and delicacy of flavor. It is equally good for winter and summer growth. Pkt,, 5 cte. oz., 15 cts.; $1 / 4 \mathrm{lb}$., 40 cts.; 1 lb............1.25 H E D ERSON'S NEW YORK-A good summer sort, slow to run to seed. Pkt., 5 cts.; oz., 15 cts.
Oak Leaved-The leaves of this variety are shaped like those of the oak tree. It forms a compact head, crisp and tender, and of good flavor. Slow to run to seed. Pkt., 5 cts.; oz , 15 cts.; $1 / 4 \mathrm{lb}, 40 \mathrm{cts}$; $1 \mathrm{lb} \ldots . . . . . . . . \$ 1.25$ Tennis Ball (Black Seeded)-Forms a close, hard head, with a few outer leaves. Pkt., 5 cts.; oz., 10 cts.; $1 / 4$ Ib., 30 cts.; $1 \mathrm{lb} \ldots . . . . . . . . . . . . .1 .00$

Black Seeded Butter-Similar to Tennis Bull, but larger. Pkt., 5 ctø.;

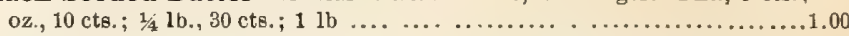

CURRIE'S PRIZE HEAD-For general nae no Lettuce has ever given euch universal satisfaction. It forms a large close head, very crisp and tender, and of excellent flavor, and has the faculty of keeping its good qualities throughout the entire eesen. We recommend this as one of the best for family use. Pkt., 5 cts.; oz., 15 cts.; $1 / 6 \mathrm{lb}, 40$ cts.; $1 \mathrm{lb}$. ......1.25

Brown Dutch-A very desirable variety for winter ase; it forms a large, solid head, the inner leaves of which are very sweet and tender. Pkt., 5

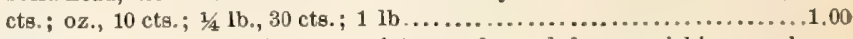

Boston Curled-A handsome variety much used for garnishing; early and of good quality. Pkt., 5 cts.; oz., $10 \mathrm{cts.;} 1 / 4 \mathrm{lb} ., 30 \mathrm{cts} . ; 1 \mathrm{lb} . . . . . . .1 .00$

HANSON-A very fine heading variety of large size. The heads are very solid, sweet, tender and crisp throughout, and entirely free from any bitter taste. Pkt., 5 cts.; oz., 10 cts.; 1/4 lb., 30 cte.; 1 lb................. 1.00

SALAMANDER-A very fine summer variety, forming fair-sized compact

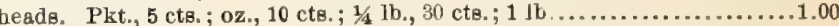

SATISFACTION-A comparatively new variety; forms large heads; very tender and crisp. Pkt., 5 cts.; oz., $10 \mathrm{cts}$; $1 / 4$ lb., $30 \mathrm{cts}$; $1 \mathrm{lb} \ldots \ldots . . . .1 .00$ DRUMHEAD, or MALTA-Heads very large, crisp, tender; one of the best summer varieties. Pkt.; 5 cts.; oz., 10 cts.; $1 / 4$ lb., 25 cts.; 1 lb. ... . . 90 All the Year Round-A hardy, compact growing variety, with small close heads of a dark-green color. Pkt., 5c.; oz., 10c.; 1/ 1b., 30c.; $1 \mathrm{lb}$... .90

Hardy Green Winter-One of the best winter varieties; forms a solid

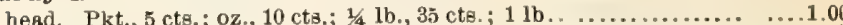

Green Fringed-This variety is besutifully cut and fringed, and furnishes an abundance of tender leaves, fit for use nearly all the summer. Pkt., 5

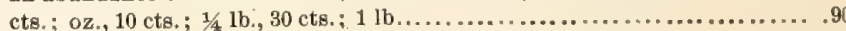

SILVER BALL-Forms a solid head of a silvery white color. Pkt, 5

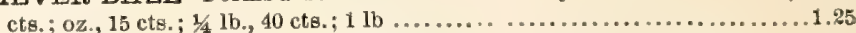
BIG BOSTON-Forms a large solid head. Pkt., 5 cte.; 0z., $10 \mathrm{cts}$; $1 / 4 \mathrm{lb}$.,

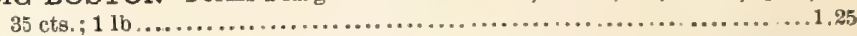
TOMHANNOCK - A handeome early variety, very crisp and tender. Pkt., 5 cts.; oz.; 15 cts.; $1 / 4$ lb., 40 cts.; 1 lb ........................ . .25 Giant White Cos-The largest and most delicious of all the Cos varieties. Heads solid and crisp. Pkt., 5 ets.; oz., 15 cts.; $1 / 4$ lb., 40 cts.; 1 lb... ...1.25

\section{ENDIVE.}

German, Endivien. French, Chicoree.

An excellent salad for fall and winter use. Sow early in spring for early crop, and in midsummer for late. No special soil or care is required until the plants have attained their full eize. Then the leaves ahould be tied up so as to exclude the light from the inner leaves, which become bleached in the course of four to eix weeks. A simpler

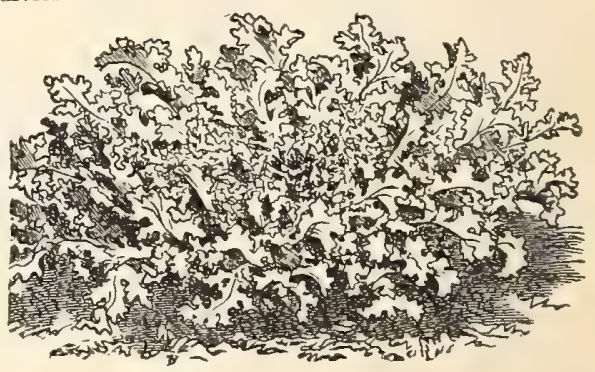

GRERN CURLED ENDIVE. method of bleaching is to cover the plants, as they grow, with boards.

If by mail in quantities of $1 / 27 b$. and upwards, postage must be added at the rate of $8 \mathrm{cts}$. per $l b$.

$10 z$. to 150 feet of drill.

Green Curled-Very hardy; lesves dark green and tender. Pkt., 5 cts.; oz. 15 cts. $; 1 / 4$ lb., 50 cts.; 1 lb...................................... 1.50

Broad Lesved Batavian-Used in soups and stews. Pkt., 5 cts.; oz.,

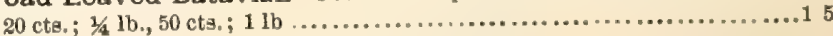
EGG PLANT.

German, Eierpflanze.

French, Aubergine.

Sow in a hot-bed the first week in April, and plant out in Junc, sbout $2 \mathrm{~L} / 2$ feet apart. For a small garden a few seeds may be raised in common flower-pots in the house

If by mail in quantities of $1 / 2 \mathrm{lb}$. and upwards, postage must be added at the rate of $8 \mathrm{cts}$. per $7 b$.

$1 \mathrm{oz}$. to 150 feet of drill.

NEW YORK IMPROVED-The best market variety; very productive.

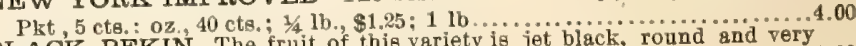
BLACK PEKIN - The fruit of this variety jet biack, roud and very 40

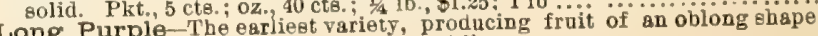
Long Purple-The earlieet variety, prod c............................2.50 


\section{Currie Bros.' Hortieultural Guide.—-}

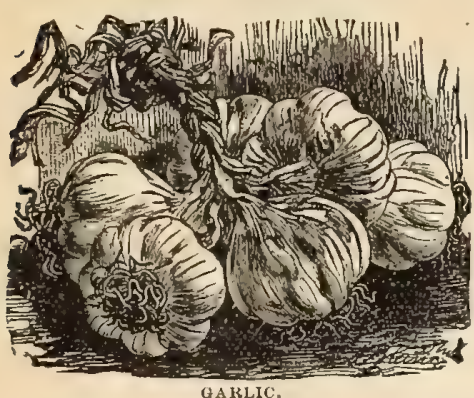

GARLIC.

\section{KALE, Or BORECOLE.}

German, Blätter-Kohl.

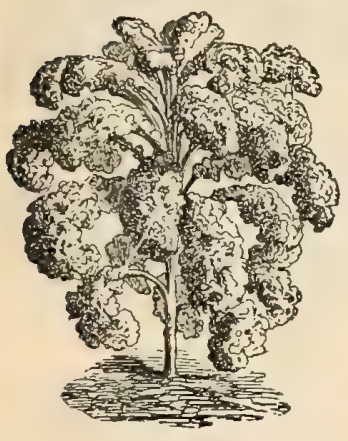

KALE, OR BORECOLE.

\section{GARLIC.}

German, Knoblsuch. French, Ail.

The gets shonld be planted in well-enriched soil early in spring, in rows one foot apart and about three inches between the plants in the row. Harvest eame as Onions.

If by mail in quantities of $1 / 276$. and upwards, postage must be added at the rate of 8 cts. per 76 .

Sets-x lb., 15 cts. ; 1b......... appearance, spreading out to about three feet in diameter. Pkt., 5 cts.; oz., 20 cts.; $1 / 4$ 1b., 50 cts. ; 11 b.................................... 1.50

German Dwarf Purple-Finely frilled leaves of a deep purple color; frequently grown for ornament. Pkt., 5 cts.; oz., 15 cts.; 1/4 lb., 25 cts. ; $1 \mathrm{lb} \ldots$

GREFN CURLED SCOTCH-Grows sbont eighteen inches in height and spreads, under good cultivation, to three feet in diameter. The leaves are bright green, besutifully curled. Pkt., 5 cts.; oz., 10 cts. ; $1 / 4$ lb., 25 cts. ;

\section{KOHLRABI.}

German, Kohlrabi. French Chou-rabe.

A popular vegetable intermediate between the Cabbage and the Turnip. Sow in drills from May to July.

If by mail in quantities of $1 / 2$ lb. or upwards, postage must be added at the rate of $8 \mathrm{cts}$. per $7 b$.

1 oz. to 3,000 plants.

EARLY WHITE VIENNA-The best market eort; flesh white and ten-

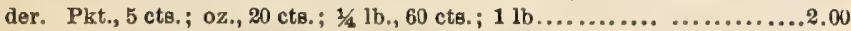

Early Purple Vienna-Differs from the above in color only. Pkt., 5 cte.;

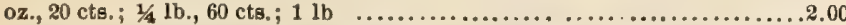

Large Green-Hardy and late; used for feeding atock. Bulbs large, weighing eight to ten pounds. Pkt, 5 cts.; oz., 15 cts.; 1/4 lb., 40 cts.

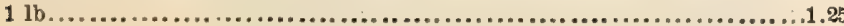

\section{MUSHROOM SPAWN.}

English-Per 1b., 15 cts.; 8 lbs., $\$ 1.00$; by mail, per lb .25

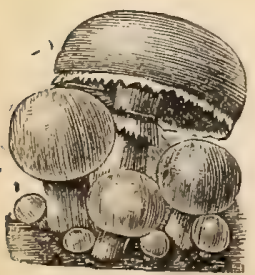

MUAHROOM BPAWN.

\section{NASTURTIUM, or INDIAN CRESS.}

The seede, while young, are pickled and used as capers.

If by mail in quantities of $1 / 2$ 2b. and upvoards, postage must be added at the rate of 8 cts. per $l b$.

Tall-Pkt., 5 cts.; 0z., 15 cts.; 1/4 lb., 40 cts. ; 1 lb.1.20 Dwarf-Pkt., 5 cte.; oz., 15 cts.; $1 / 4$ lb., 50 cts.

$1 \mathrm{lb}$

\section{LEEK.}

German, Lauch.

Fr znch, Poireau.

In our opinion, the Leek does not receive th $\theta$ attention it de serves. It is easily cultivated, and is a aluable gddition to the vegetables generally used in soups, etc Sow early in spring, and when about gix inches high transplant into rows about ten inches apart each way, and as deep as possible to perfect the blanching procese. Thericher the soil, the finer the Leeks will grow.

If by mail in quantities of $1 / 2 l b$. and upwards,postage must be added at the rate of $8 \mathrm{cts}$. per $7 b$.

1 oz. to $100 \mathrm{ft}$. of drill.

LARGE AMER-

ICAN FLAG-

A fovorite mar ket variety. Pkt,

5 cts.; oz., 15 cts. ;

1 . $1 \mathrm{~b}, 30 \mathrm{cta}$

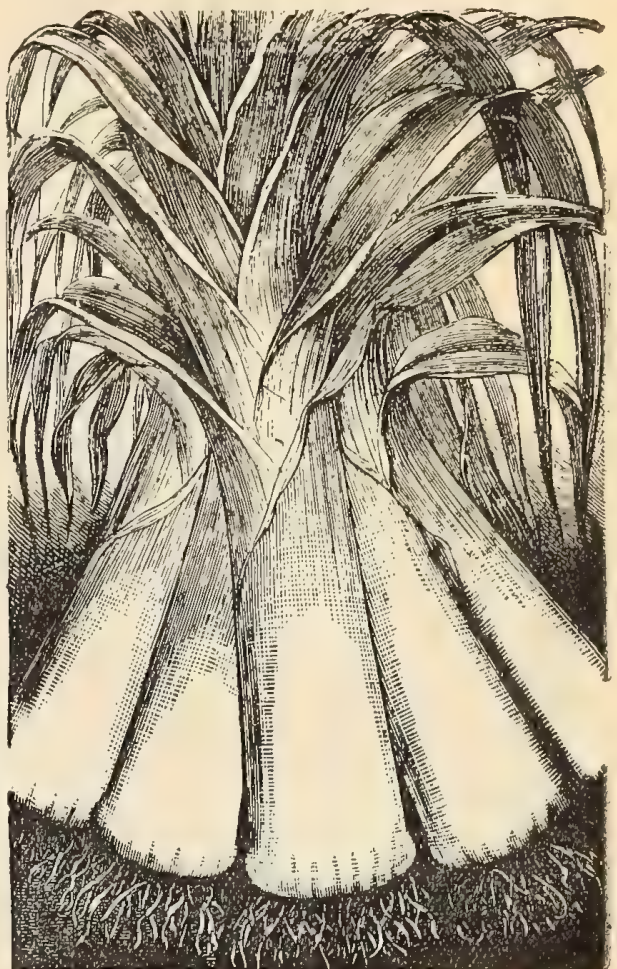

MUSBELBURG LEEK
MUSSELBURG, or SCOTCH CHAMPION-Grows to a large size.

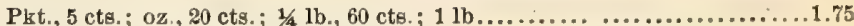

LARGE ROUEN-An excellent large variety. Pkt., 5 cte. ; oz., 20 cts. ; 1/4

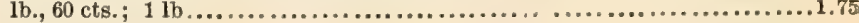

\section{MUSTARD.}

German, Senf. French, Moutarde.

A pungent salad.

For winter use, sow

If by mail in

added at the rate

White London-

az, $10 \mathrm{cts}, ; \mathrm{z} / \mathrm{lb}$

Brown-More pun

ets.; oz , 10 cts.;

\section{Mi}

The seed-pode, wl used for pickling. and transplant two $f$

If by mail in wards, postage m? cts. per $l b$.

Martynia Probos

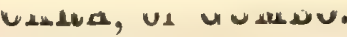

German, Easbarer "Okra." French, Gombo.

The pods, when young, are used in soup, stews, etc., and are very nutritions. It is of the easiest culture, and grows freely in any ordinary garden soil. Sow at the usual time of all tender vegetables, and set the plants from two to three feet apart in drills.

If by mail in quantities of $1 / 2 l b$, and uproards; postage must be added at the rate of $8 \mathrm{cts}$. per $\mathrm{lb}$.

Improved Dwarf Green-Early and productive. Pkt., 5 cte.; oz., 10

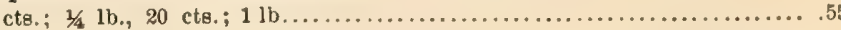

Long Gresn-Long ribbed pods. Pkt., 5 cts.; 0z., 10 cts.; $1 / 4 \mathrm{sb.,} 20$ cts.;

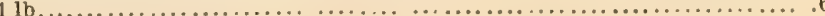




\section{MELON-Musk. \\ German, Melone. French, Melon.}

The Melon growe best in a light soil. Plant in hills about six feet apart, mixing in each hill a shovelful of well-rotted manure. Sow about a dozen seede in every hill, early in May, and when well started, thin out to three or four of the strongest plants. Pinch off the strong shoots and thin out the young fruit if It eets too plentifully, so as to increase the size of the remainder.

If by mail in quantities of $1 / 2 l b$. and uproards, postage must be added at the rate of $8 \mathrm{cts}$. per $\mathrm{lb}$.

1 oz. to 50 hills. 2 to 3 lbs. per acre in hills.

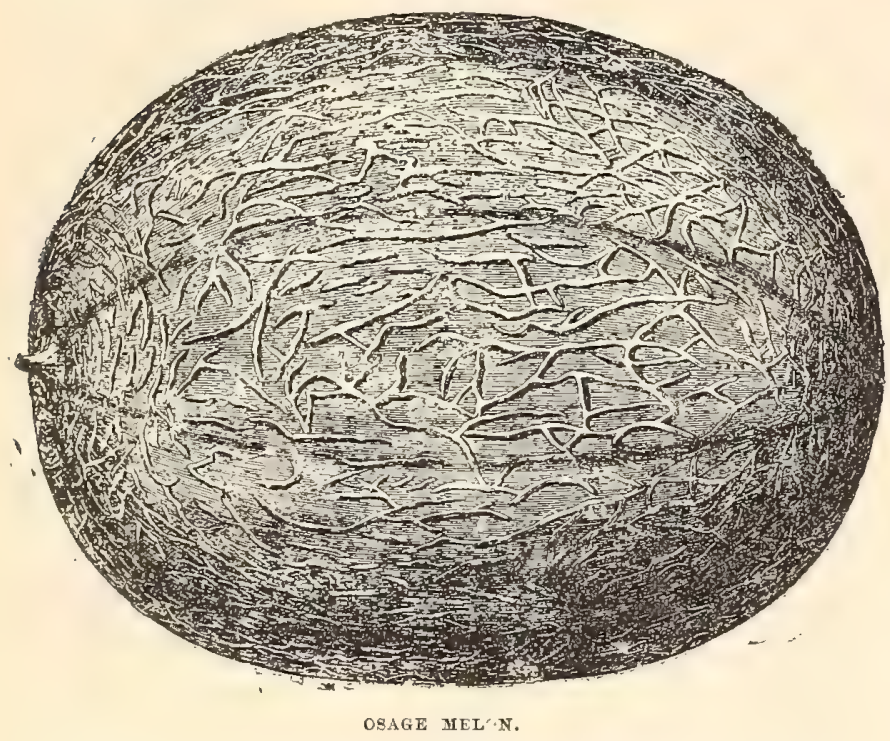

OSAGE-This is unquestionably one of the finest Melons ever produced in this country, and we think it destined to fake the lead of all others at present in use. Its outward appearance will at all times command a ready sale. It is of medium size, reту productive, and unsurpassed in the delicacy of its flavor. The flesh is reddieh orange, thick and juicy, retaining its sweel ness close to the rind. Pkt., 5 cts.; oz., 10 cts.; 16 lb., 30 cts. ; $1 \mathrm{lb}$.

THE BANQUET

-An excellent

medium sized

Melon, round

in shape and

beautifully net-

ted. The flesh

is thick and of

superior quali-

ty; color, rich

a alm on red.

Pkt., 5 cts. ; oz.,

20 cts.; $1 / 4$ lb., 60

cts.; $1 \mathrm{lb} . . . .2 .00$

CHAMPION

M A R KET-

E a r ly, round

and deeply net-

ted. Very pro-

ductive, asually

weighing from

esh thick, light

green, and very sweet flavor. Pkt., 5 cts.; oz., 10 cts.; $1 / 3$ ib., 30 cts.; 1 lb...1.00 NEW SUPERIOR-Like the preceding, this variety is round and deeply netted. The fiesh is thick and light green, and very sweet. Pkt., 5 cts.;

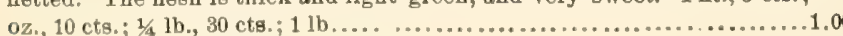

Improved Christians-A leading sort; flesh rich yellow. Pkt., 5 cts.; oz., $10 \mathrm{cte}$; 1/4 lb., $25 \mathrm{cte}$; $1 \mathrm{lb}$....

THE PRINCESS-It is round, large, heavily netted, dark green skin and thick flesh, which is a beantiful salmon color. It ripens early and has a most delicious flavor. Pkt., 5 cts.; oz., $10 \mathrm{cts}$; $1 / 2 \mathrm{lb} ., 25 \mathrm{cts} ; 1 \mathrm{lb} . . . . .$. FMERALD GEM-Th1s is a most excellent variety of superior flavor and quality. Onteide skin emerald green and smooth; flesh salmon, very thick and juicy. Pkt., 5 cts。; oz., 10 cts.; 1/4 lb., 30 cte. ; 1 lb. 1.00

Winter Pinespple-The Melone shonld be picked green and stored in a cool, dry placel to ripen over winter. Pkt., 10c.; oz., 40c.; 1/4 lb. $\$ 1.00 ; 11 \mathrm{~b} .4 .00$
MILLER'S CREAM--One of the most delicious Melone now in use. The flesh is of a rich salmon color, very thick and sweet. Pkt., 5 cts.; oz.,

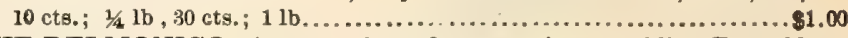

THE DELMONICO-A new variety of rare merit, resembling Emerald Gem in color and flavor, but grows to double the size; oval shaped and deeply netted. Pkt., 5 cts.; oz., 15 cts.; $1 / 4,1 b ., 50$ cts.; 1 lb.............1.50

Large Yellow Cantaloupe-Early and prolific; flesh reddish orange, of good flavor. Pkt., 5 cts.; oz., 10 cts.; 1/4 lb., 25 cts.; 1 lb............ .75

Casaba-A large variety of fine flavor. Pkt., 5 ets.; oz., 10 cts.; $1 / 4$ lb., 25 cts.; $1 \mathrm{lb}$.

Celifornia Nectar-A medium-sized sort of fine flavor; flesh thick and juicy. Pkt., 5 cts. ; oz., 10 cts.; 1/4 lb., 35 cts.; 1 lb......................... ACME or BALTIMORE

- Resembles the Bay View, but more pointed. Very productive. Pkt., 5 cts.; Oz., 10 cte.; $1 / 4 \mathrm{Ib}, 25 \mathrm{cts} . ; 1 \mathrm{lb} . .$.

Green Citron-Shape nearly round; deeply netted; from 6 to 8 inches in diam.; flesh green and of rich, delicions flavor. Pkt., 5 cts.; oz., 10 cta.; $1 / 4$ lb., 25 cts. : $1 \mathrm{lb}$.

Jenny Lind - A medium early varjety, of small size, bat excel lent flavor. Pkt., 5 cts.; oz., 10 cts.; 1/4 1b., 25 cts.; 1 lb.

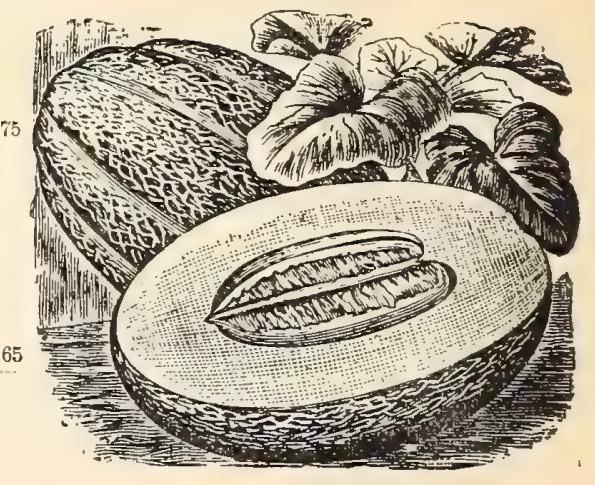

.65
THE DELMONICO.
SURPRISE-An early sort having a thin, cream-colored skin, and thick, salmon-colored flesh; very productive, and of delicious flavor. Pkt.,5

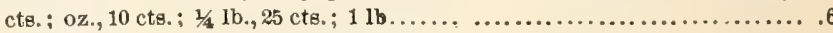

Nutmeg-Nutmeg shaped; finely netted; flesh greenish-yellow, rich and

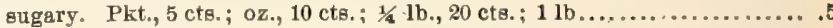

THE HACKENSACK-A popular variety of large size. It is round in shape, flattened at the ends; is of most delicious flavor, and wonderfully productive. Pkt., 5 cts.; oz, 10 cte.; 1/4 lb., 25 cts.; $1 \mathrm{lb}$.

EXTRA EARLY HACKENSACK--Similar to the preceding, but about two weeks earlier, making it a valuable acquisition. Pkt., 5 cts.; oz., 10

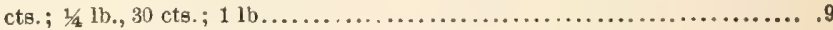

Banana-A long-shaped Melon growing from eighteen to twenty-four inches apart; flesh salmon-red. Pkt., 5 cts.; oz., 10 cts.; $1 / 4 \mathrm{lb} ., 25$ cts. ;

NHTTED GEM-A very early variety of small size. It is globe-shaped,

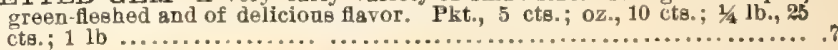
ctg. 11 lb .........................................................

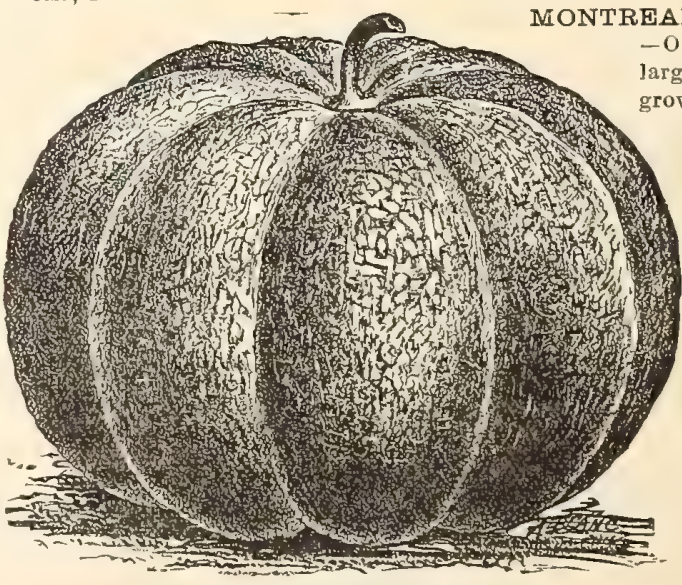

MONTREAL MAREET. $-\mathrm{On} \theta$ of $\mathrm{h} \theta$ largest Melon grown, specimens h a ving we i g h ed over 30 lbs. Flesh green, thick and of very fine Havor. Pkt. 5c. ;0z, 10c.; $1 / 4$ Ib., 25c.; 1 lb........? PROLIFIO NUTMEGThis variety, as name o $\mathrm{g}$. $\mathrm{g} \in \mathrm{B} \mathrm{t} \mathrm{s}$, is very pro-

lific; fruit of medium size; thick green flesh of very fine flavor. Pkt., 5

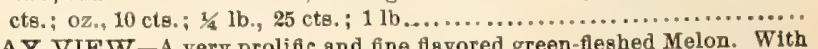
BAY VIEW-A very proliffc and fine flavored green-fleshed Melon. With ordinary cultivation this variety has produced Melons weighing from 10 Skillman's Netted-An early and delicious variety, with sweet, deepgreen flesh, richly perfumed. Pkt., 5 cts.; oz, 10 ctø.; $3 / 4$ lb., 25 cts.; 60 White Japan-A fine flavored early variety, of medium gize; skin creamy

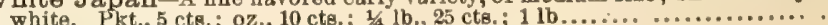
CHICAGO MARKET--Pkt., 5 cts.; 0z., 10 cts.; 34 1b., 25 cts.; 1 lb...... .75 For large quantities write for special prices. 


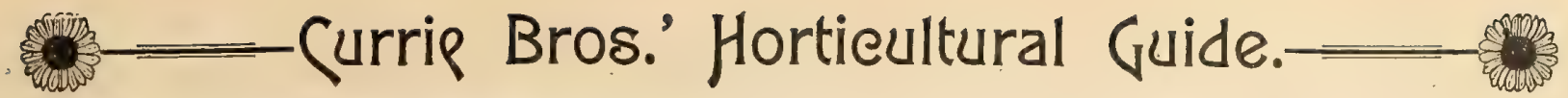

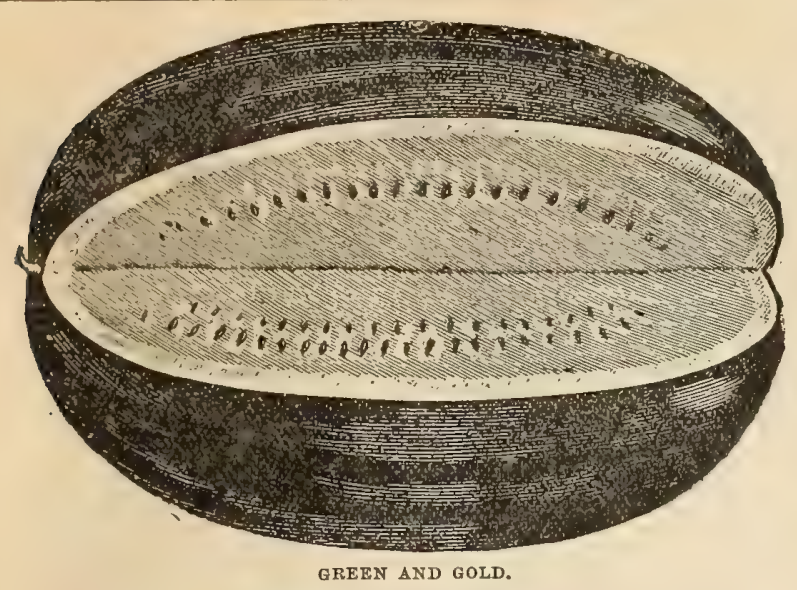

MELON-Water.

German, Wrsser-Melone. French, Melon d'Eau.

Watermelons require a rich, sandy soil for best development, and do best in warm latitudes. Cultivate same as Muskmelon, except that the hills should be nearly double the distance apart.

If by mail in quantities of $1 / 2 l b$. and upwards, postage must be added at the rate of $8 \mathrm{cts}$. per $7 b$.

1 oz. to 30 hills; 3 to 5 lbs. per acre.

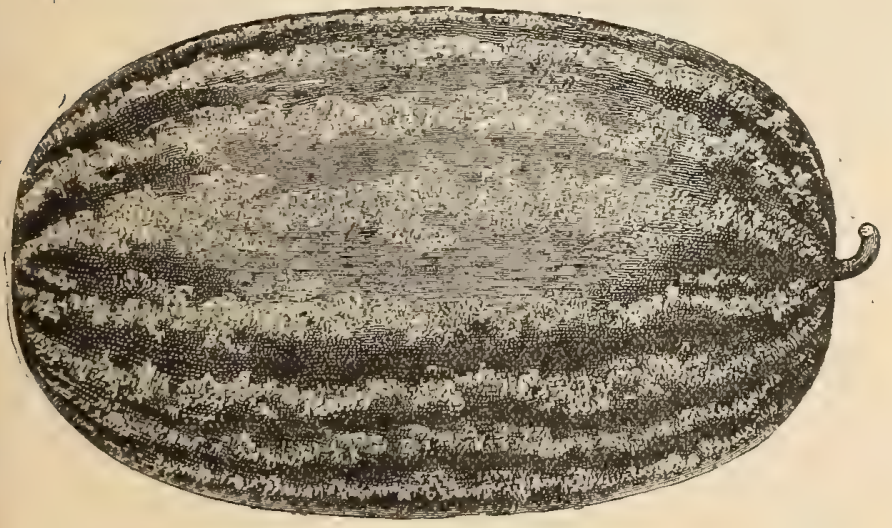

DIXIE WATER MELON.

DIXIF-An early and very productive variety, surpassing the $\mathrm{c}^{n} \mathrm{n}^{\mathrm{r}}$ rated Kolb Gem in many respects. It has a fine appearance, is very nai $y$ and sn excellent shipper, and its eating qualities are the very best. Pkt., 5

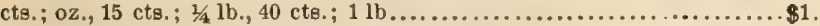

HUNGARIAN HONEY $_{\text {A }}$ A very fine early variety. The fiesh is bright red and of a rich honey flavor. It is of medium size. Pkt., 5 cte.; oz.,

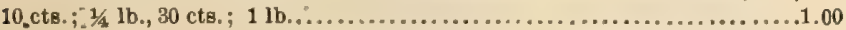

VAUCLUSE-Very !early and of large eize. Flesh bright red, and very 8weet. The rind is, thin but very tough. Pkt., 5 cts.; oz., 10 cts.; 1/4 lb.,

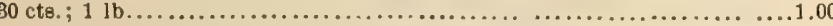

GRAY MONARCH, or LONG WHITE ICING-A large oblong-ehaped Melon of very fine quslity. Flesh deep red. Pkt., 5 cts.; oz., 10 cts, ; $1 / 4$

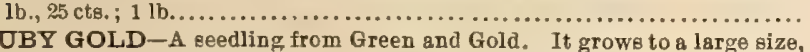
usually.weighing 40 to $50 \mathrm{lbs}$. The quality is excellent, being very juicy and fine flavored. Pkt., 5 cte. ; oz., $15 \mathrm{cts}$; $1 / 2$ 1b.; $35 \mathrm{cts}$; 1 lb...........1.00

GREEN AND GOLD-The flesh of this variety is a golden orange color, juicy and sweet; very early. Pkt., 5 cts.; oz., 15 cts.; 1/4 1b., 25 cts.; 1 lb. . .65 CHRISTMAS-A valuable variety of handeome appearance: The flesh Is a rich scarlet and very solid, and of excellent flavor. It is a good keeper and ships well. Very productive. Pkt., 5 cts. ; oz., 10 cts.; $1 / 4 \mathrm{lb}$., $25 \mathrm{cts}$; $1 \mathrm{lb}$.

Scaly Bark-A popular market variety, covered with mottled green epots, looking like, fish-ecales. It will keep in good condition after picking longer than any other sort; fruit large, oblong; flesh red and very tender. Pkt., 5 cts.; oz., 10 cts.; $1 / 4$ lb., 25 cts.; 1 lb......................

PEERLESS, ICE CREAM-Of medium size, thin rind, light mottled green; flesh bright scarlet, eolid to the center and sweet 8 s honey. Pkt., 5 cts. ; oz., 10 cts.; $1 / 41$ b., 25 cts. ; 1 lb.................................
THE VOLGA - A round sort of small size, but unsurpassed in crispness

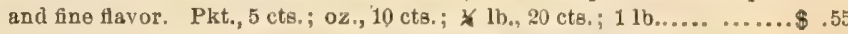
KOLB'S GFIM - A valuable variety. The fruit is large, weighing from 25 to 50 lbs, It has a delicious flavor, and its keeping qualities are the best. Pkt., 5 cts. oz., 10 cts.; $1 / 4$ lb., 20 cte.; $1 \mathrm{lb}$. . .

Seminole-A large early variety, oblong in shape, very productive and of excellent quality. Pkt, 5 cts.; oz., $10 \mathrm{cts}$; $1 / 4$ 1b., 20 cts.; 1 lb.... .60

BOSS-An early oblong-shaped variety. Flesh deep scarlet and unusually sweet flavored. Skin dark green; rind very thin and tough. Pkt., 5 cte. oz., 10 cte, ; $1 / 4 \mathrm{lb}, 25 \mathrm{cts}$; I lb.

Dark Icing - A very prolific variety of good size and delicious. flavor. $\mathrm{Ob}$ long; thin rind. Pkt., 5 cts.; oz., 10 cts.; $1 / 4$ lb., 25 cts.; 11 lb. .

True Georgia Rattlesnake, or Gipsy-Fruit large, oblong, striped flesh red, of fine quality. Pkt., 5 cts. ; 0z., 10 cts.; $1 / 4$ lb., 25 cts.; 1 lb...... .

Mountain Sweet-Fruit large, oblong, dark green; flesh oolid and very

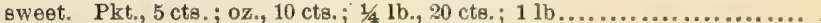

Phinney's Earjy-Flesh deep red, of fine quality; early and productive Pkt., 5 cts.; oz., 10 cts.; $1 / 4$ lb., 25 cts. ; 1 lb.

Cuban Queen-In quality equal to the best, while its solidity is so marked that it will weigh one-third more than Melons of the same size of other varieties, specimens often weighing 80 pounds and upwards. Pkt., 5 cts. ; oz., 10 cts.; $1 / 4 \mathrm{lb}$., 20 cts.; $1 \mathrm{lb}$. .

Mountain Sprout-An excellent late variety. Pkt., 5 cts.; oz., 10 cts. $1 / 4$ lb., 20 cts.; 1 lb

Mammoth Iron-Clad-A large variety of delicious flavor, keeping its flne quality to quite near the outer skin. It is a good shipping variety. Pkt., 5 cts. ; oz., 10 cts.; $1 / 4$ lb., 20 cts.; 1 lb............................

Citron-A round fruit of small size, used in making preserves. Pkt, 5 cts. oz., $10 \mathrm{cts}$; $1 / 4$ lb., $20 \mathrm{cts}$; $1 \mathrm{lb}$.

COL,ORADO PRESERVING MELON--Distinct from the ordinary Citron. It is very productive; flesh firm and solid, making beautiful clear preserves of excellent flavor. Pkt., 5 cts.; oz, 10 cts.; 1/4 lb., 20 cts, $1 \mathrm{lb}$

\section{VINE PEACH.}

\section{Vegetable Orange, or Mango Melon.}

The fruit is a bright orange color, oval shaped, and about the size of an ordinary peach, which they resemble very much. They are excellent for preserves or sweet pickles, and, when fully ripe, are considered a delicacy sliced raw and served with sugar. Pkt., 5 cts,; oz.

\section{PARSLEY.}

German, Petersilie. French, Persil.

Parsley thrives best in a rich soil. The seeds germinate very slowly, three or four weeks "generally elapeing before it makes its appearance. Sow early in spring half an inch deep, previously soaking the seeds for a few hours in tepid water.

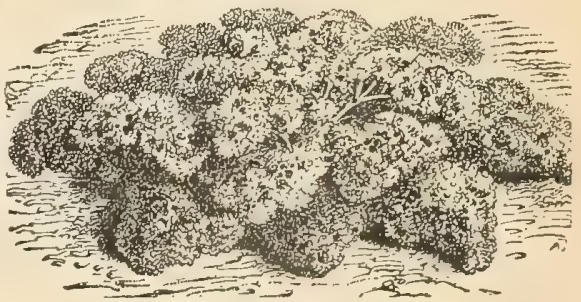

If by mail in quantities of $1 / 2 l b$. and upwards, postage must be added at the rate of 8 cents per $l b$.

1 oz. to 150 feet of drill.

Plain-Leaves plain. It is hardier than the curled variety. Pkt., 5 cts.

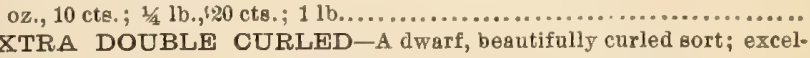

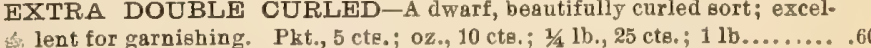
CHAMPION MOSS CURLED-A beautifully crimped and curled va-

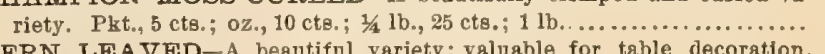
FERN LEAVED-A beautiful variety; valuable for table decoration. HAMBURG, or TURNIP-ROOTED-Fleshy-rooted; the roots are used for flavoring eoups. Plet, 5 cts.; oz., 10 cte.; $1 / 4$ lb., 25 cte.; 1 lb ... . 5 


\section{8 - Currie Bros.' Hortieultural Guide.}

\section{ONION.}

German, Zwiebel. .. French, Oignon.

The Onton is most successfully grown in a deep, rich, loamy soil, and, unlike most vegetables, does best when cultivated in the same ground for a succession of years. Trench and manure the ground well in the fall, and turn up in ridges during the winter, and as early as the ground will work in spring, rake or harrow thoroughly so as to get the soil fine and level. Sow thinly in drills half an inch deep, twelve inches apsrt, and cover with fine soil, preseing it down with the back of a spade or light ruller. Keep the ground free from weeds, and thin out the young plants so they stand three or fonr inches apart.

If by mail in quantities of $1 / 2 \mathrm{lb}$. and uproards, postage must be added at the rate of $8 \mathrm{cts}$. per $\mathrm{lb}$.

1 oz.jto 100 feet of drill. 5 to 6 lbs. per acre in drills.

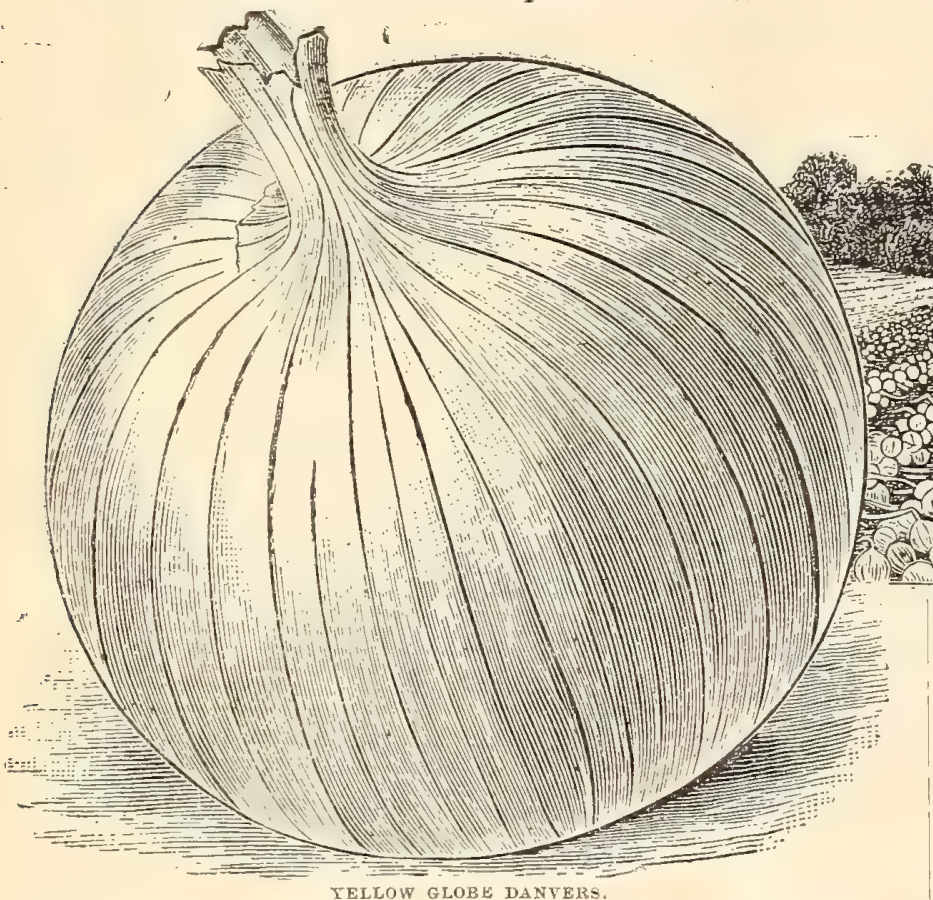

SPANISH KING-The largest;and handsomest Onion we have ever grown;

skin golden yellow; flesh white, and so mild and sweet that it may be

eaten raw like an apple. Pkt., 5 cts.; oz., 30 cts. ; 1/4 1b., 85 cts.; 1 lb.... $\$ 3.00$

WETHERSFIELD LARGE RED--Of large size, deep color, and an ex-

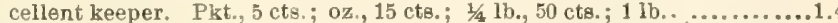

EXTRA EARLY FLAT RED-A medium-sized flat variety, producing

abundantly and coming into use about two weeks earlfer than Red Weth-

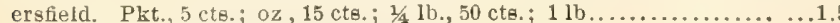

EARLY RED GLOBE--Matures about the same time as Wetherefield;

mild and tender. Pkt., 5 cts.; oz., $15 \mathrm{cts}$; 1/4 lb., $50 \mathrm{cts.;} 1 \mathrm{lb} . . . . . . . . .1 .50$

WHITE PORTUGAL, or SILVER SKIN-Extensively grown for

pickling. The bulb is handsome and mild flavored. Pkt., 5 cte.; oz., 25

WHITE GLOBE-Similar in shape to the Silver Skin; of mild flavor, and

a good keeper; one of the very best. Pkt., 5 cts.; oz., 25 cts.; 1/4 lb., 75

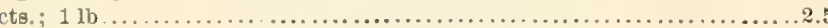

YELLOW GLOBE DANVFRS (Select)-The leading variety; very pro-

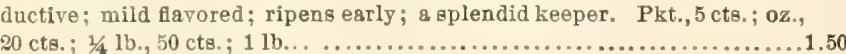

YELLOW DANVERS-Same as the preceding, but flatter, fine stock.

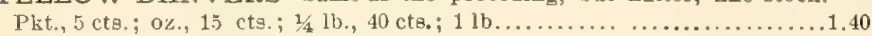

QUEEN-An excellent variety, remarkable for ite keeping qualities and

the rapidity of its growth. Pkt., 5 cts.; oz., $20 \mathrm{cts}$; $; / 4$ lb., $60 \mathrm{cts}$; $1 \mathrm{lb} . .2 .00$

WHITE SILVER SKIN (Imported -This is of emall eize; allvery white.

Pkt., 5 cts.; $02 ., 20 \mathrm{cts} ; 3 / 4 \mathrm{lb}, 60 \mathrm{cls}$; $1 \mathrm{lb} \ldots \ldots \ldots \ldots \ldots \ldots \ldots \ldots \ldots \ldots \ldots \ldots$
SOUTHPORT YELLOW GLOBE-A very handsome Onion; oblong

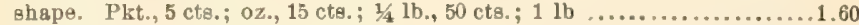

SOUTHPORT WHITE GLOBE-One of the leading white Onions; a

large yielder, of mild flavor. Pkt., 5 cts. ; oz, 25 cts.; 1/4 lb., 75 cts.; $11 \mathrm{lb} . .2 .50$

SOUTEPORT RED GLOBE- Similar to the preceding varieties, differing in color, which is a bright crimson. Pkt., 5 cta.; oz., 15 cts.; 1/4 lb., 50

SILVER KING-An Italian variety, very extensively used in the South. It grows to a very large size, and of mild flavor. Pkt., 5 cts.; oz., 25 cts.;

For large quantities write for special prices.

\section{ONION SETS.}

Sets should be plsnted out as early in the spring as the ground will permit. Plant them in rows one foot apart, with sets three or four inches apart.

Add 10 cts. per quart extra if to be sent by mail.

1 quart to 40 feet of drill.

White Onion Sets-Quart

Yellow Onion Sets-Qunt.

Prices subject to variation. Write for prices of large quantities before ordering.

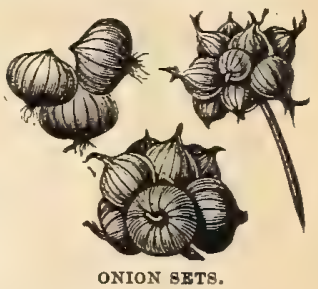

\section{CHIVES-Schnittlauch.}

Very small, hardy Onione, used for salad. Per doz., 25 cts.; per 100 .85

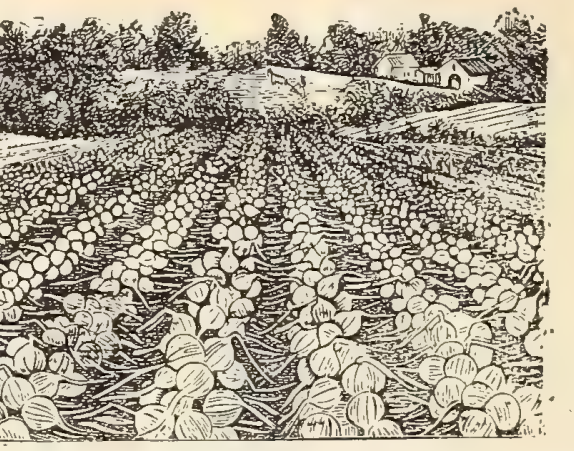

PEPPER.

German, Pfeffer

French, Piment.

Sow in hot-bed early in April, and traneplant to the open ground when the weather is farorable. Plant in warm, mellow soil, in rows 18 inches apart.

If by mail in quantities of $1 / 2 l b$. and upwards, postage must be added at the rate of 8 cents per $l b$.

10\%. to 1,000 plants.

NEW CELESTLAL-A very prolific variety, with small fruits 2 to

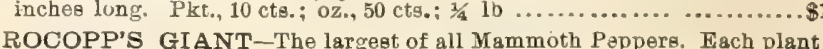
ripens about a dozen fruits from 8 to 10 inches long and 3 inches thick, of a brilliant scarlet color, with flesh fully one-half inch thick. Pkt, 10 cts.; oz., 40 cts, ; 14 lb . ..... RED CLUSTER-A variety of the Chili type, having bright red upright fruits, which are produced in great abundance. Pkt., 5 cte.; 0z., 30 cts.; * lb., 85 cts.; 1 lh

LONG RED CAYENNE-Fruit bright red, conical, from 3 to 4 inches in length; very productive. Pkt., 5 cte.; oz., 25 cts.: 1 1/4 lb., 75 cts.; $11 \mathrm{~b} .2 .40$ SWEET SPANISH-A large and early variety; flesh sweet and mild. SWEET MOUNTAIN, or MAMMOTH-Similar to the preceding in shape and color, but larger and milder. Pkt., 5 cts.; oz., 25 cte.; $1 / 4$ lb.,

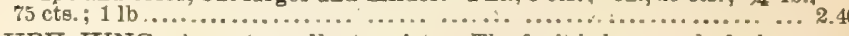

RUBY KING-A most excellent variety. The fruit is large and of a beautiful ruby red color, and is remarkably mild, often being eaten sliced with pepper and vinegar like Tomatoes. Pkt., 5 cts.; oz., 30 cts.; 1/4 lb., 85 LARGE BELL, or BULL NOSE-Early and mild; rind thick and fleshy. Pkt.. $5 \mathrm{c}$ :
oz., $25 \mathrm{c}, 1 / 4$
lb., $75 \mathrm{c} ; 1$

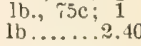
GOLDEN DAWN-

A beautifa

new varie

ty, similar

shape to

the $B$ un altogether

differ $\begin{gathered}\text { a } t \\ \text { d }\end{gathered}$

in color.

being a

beautitul

golden yel-

of \& very

superior

flavor. Plkt.

$5 c ; 0 z .25 c$;

${ }_{1}^{1 / 4 b} \mathrm{lb} . . . .25 .40$

Chili Red

- Largely

used in the

ture of pep-

per-asuce:

per-8auce

very pro

5c: oz. $25 \mathrm{e}$ :

$11 \mathrm{~b} . . .2 .2 .40$

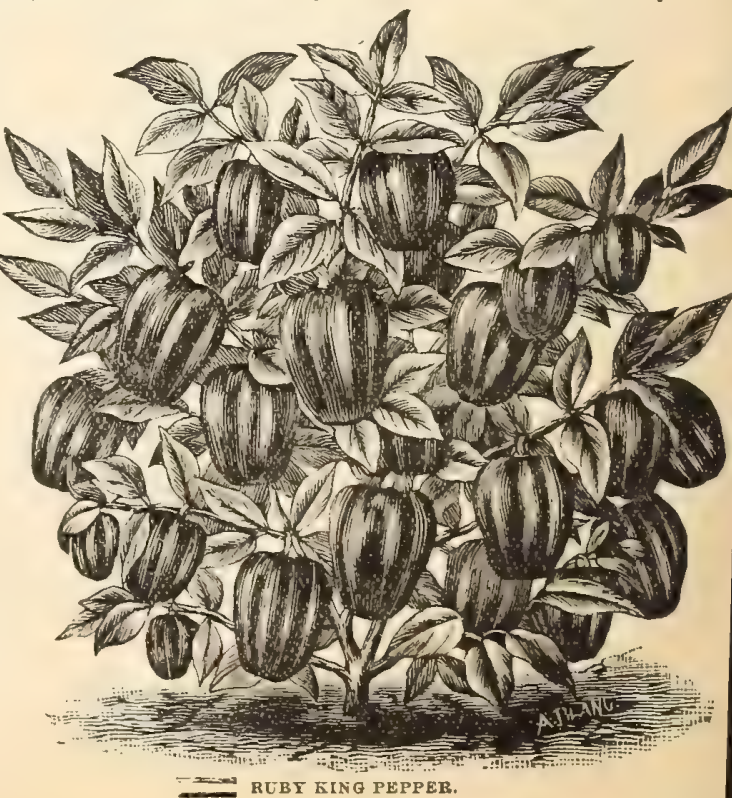




\section{Currie Bros.' Hortieultural Guide ———

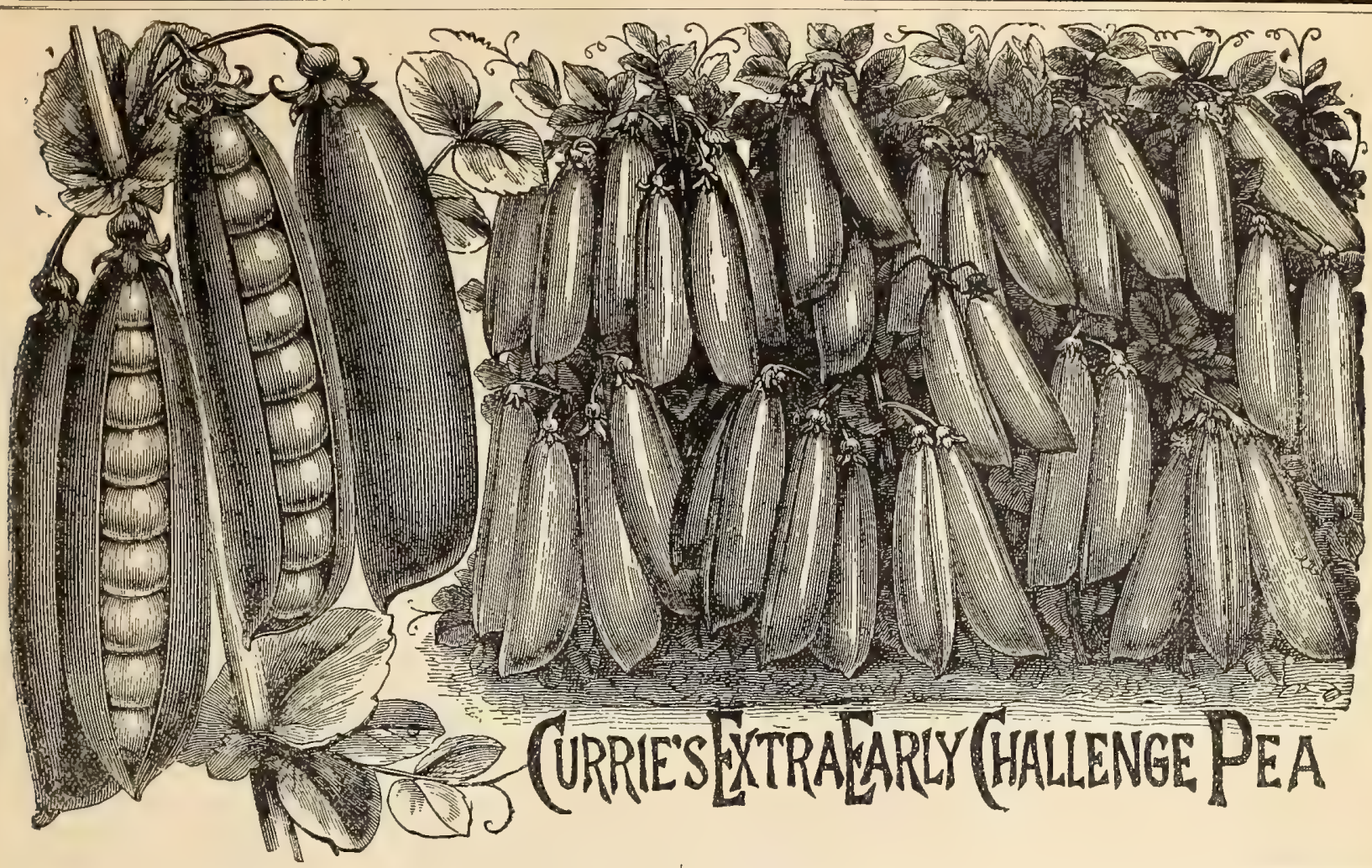

PEAS.

German, Erbee. French, Poiø.

For early Peas sow in light, rich soil, and for general crop a stiff soil is best. Manure well, especlally for dwarf varieties, and sow in rows two to three inches deep, and from two to three feet apart, according to the variety. For an early crop sow in February or March, or as soon as the ground can be worked; and for later varieties gow in April or May. Discontinue sowing from June to August, after which, by sowing an early sort, a good crop can generally be secured.

If by mail in quantities of a pint and uproards, add 15 ets. per quart for postage.

1 quart to 75 feet of drill. 2 bushels to an acre in $d r i l l s$.

\section{EXTRA EARLY VARIETIES.}

Those marked thus * are wrinkled.

OURRIE'S EXTRA EARLY CHALLENGE-No extra early Pea has ever givon the universal satisfaction among market gardeners that this ono has. Grown alongside of other extra early varieties the Challenge not only proved earlier, but much more productive. It is an enormous bearer and ripens very early, so that the vines may be cleared off in two pickings, and the ground prepared for another crop before other early varietie come into use. The pods are very large and well filled with round Peas of ine flavor. In our large Pea-growing districte the Challenge ls how planted for an extra early, to the total exclusion of all other early varieties. Pkt., 5 cts.; pint, 15 cts.; quart, 25 cts.; peck, $\$ 1.25$; bushel.

MAUD S-One of the most desirable extra early varieties, a good cropper of excollent quality. Plzt., 5 cts.; pint, 15 cts. ; quart, 25 cts.; peck, $\$ 1.25$; buabel.

ALASKA - An extra early variety of superior quality. The vines grow to a height of ahout $2 \frac{1}{2}$ feet and produce abundantly. Pkt., 5 cts.; pint, 15 cts.; quart, 25 cts.; peck, $\$ 1.25$; bushel.............................4.5

BLUE BEAUTY-A dwarf extra early variety, coming in a little later than American Wonder. It grows to a nniform height of about $13 / 4$ feet. The pods are of medium size and are produced abundantly. Pkt., 5 cts.; pint, $16 \mathrm{cls}_{0}$; quart, 30 cts. ; peck, 81.50 ; bushel.......................5.50

Philadelphia Extra Erarly-A desirable early variety. Pkt., 5 cts. pint, 15 cts.; quart, 25 cts.; peck, $\$ 1.25$; bushel .....................4.00

"Laxton's Alpha-One of the earliest wrinkled Peas; of fine quality and very prolific; pods large, and well filled; 3 feet. Pkt, 5 cts.; pint, 15 cts. ; quart, 95 cts.; peck, $\$ 1.25$; bushel..............................4.50

Oaractacus-One of the best early sorts; $2 / .2$ feet. Pkt., 5 cte. pint, 15 cts. ; quart, 25 cts.; peck, $\$ 1.25$; bushel...........................4.00
*AMERICAN WONDER-One of the earlieat wrinkled Peas in cultivation, of the finest quality and flayor, and wonderfully productive. It great distinctive festure, however, is its compact and dwarf growth, seldom exceeding ten inches in height. Pkt., 5 cts.; pint, 15 cts.; quart, 30 cts.; peck, $\$ 1.50 ;$ bushel....................................\$b.

Carter's First Crop-One of the earliest varieties; 2 y feet. Pkt., 5 cts. ; pint, 15 cts. ; quart, 25 cts. ; peck, $\$ 1.25$; bushel .....................4.00 Improved Daniel O'Rourke-A favorite extra early variety. Pkt., 5 cts. ; pint, 15 cts.; quart, 25 cts. ; peck, $\$ 1.25$; bushel..................4.00 Kentish Invicta-A prolific early variety of fine flavor; $2 \frac{1}{2}$ feet. Pkt., 5 cts.; pint, 15 cts. ; quart, 25 cts.; peck, $\$ 1.25$; bushel..................4.00 Early Kent-An early variety with good-sized, well-filled pode; $21 / 2$ feet. Pkt., 5 cts.; pint, 15 cts. ; quart, 25 cte. ; peck, $\$ 1.25$; bushel............4.00 Summit-A good variety and one of the earliest. Pkt., 5 cts. ; pint, 15 cts.; quart, 25 cts.; peck, $\$ 1.25 ;$ bushel ..........................50

\section{SECOND EARLY VARIETIES.}

*SUTTON'S SATISFACTION-(See Novelties). Pkt., 15 cts.; pint, 40 cts.; quart..................... HORSFORD'S MARKET GARDEN-A good wrinkled variety matur ing between Little Gem and the Advancer; very prolific and sweet. The vines grow about 2 feet high. Pkt., 5 cts.; pint, 15 cts. ; quart, 25 cts. peck, $\$ 1.50$; bushel.

*PREMIUM GEM-A dwarf Pea of the Little Gem type, on which it is a great improvement. Pkt., 5 cts.; pint, 15 cts. ; quart, 25 cts. ; peck, $\$ 1.25$;

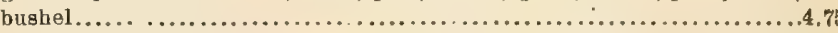

TOM THUMB-Very dwarf and early; of excellent quality; yields sbundantly; 1 foot. Pkt., 5 cts.; pint, 15 cts. ; quart, 30 cta.; peck, $\$ 1.50$; bushel.5.50 *McLEAN'S LITTLE GEM-Az early dwarf, green, wrinkled Pea, of superior flavor, and very prolific; 1 foot. Pkt., 5 cts. ; pint, 15 cts.; quart, 25 cts. ; peck, $\$ 1.25$; bushel................................... 45

MCLEAN'S BLUE PETER-A larger, better and earlier form of Tom Thumb, having blue seed. Very dwarf and early; a good bearer, and of excellent quality. Plzt., 5 cts.; pint, 15 cts.; quart, 25 cts.; peck, 81.50 ;

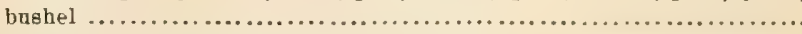

*BLISS' EVERBEARING - The vines grow about 18 inches high, throwing out from the axil of each leaf branches which will in turn bear pode, thus prolenging its duration of bearing. Peas are of superior flavor and very tender. Pkt., 5 cts.; pint, 15 cts.; quart, 25 cte.; peck, $\$ 1.25$; bushel.4.50

*BLISS' ABUNDANCE-Remarkably productive and of excellent quality. The plant is of a branching habit, each branch often producing as many pode as an entire plant of some of the older varieties; $1 \mathrm{~b} / 2$ feet. Pkt., 5 cts.; pint, 15 cts.; quart, 25 cts.; peck, $\$ 1.25$; bushel .................5.00 *Eugenie-A good Pea of excallent quality; 11/2 feet. Pkt., 5 cts.; pint, 15 cts.; quart, $25 \mathrm{cts}$; peek, $\$ 1.50$; bushel..........................6.50 


\section{PEAS.}

FOR GENERAL CROP.

Duke of Albany-A very superior Pea; pods of very large size; quality the very best. Pkt., 5 cts.; pint, 25 cts. ; quart, 50 cts. ; peck, $\$ 2.50$; bushel. $\$ 9.00$

*Yorkshire Hero-A fine wrinkled sort, of branching habit, and an abundant bearer ; $2 \frac{1}{2}$ feet. Pkt., 5 cts.; pint, 15 cts. ; quart, 25 cts. ; peck, $\$ 1.25$; bushel..........

* STRATAGEM-One of the best wrinkled Peas introduced in late years. It is dwarf, a very heavy cropper, and produces large, well-filled pods, and it is of excellent flavor. Pkt., 5 cts.; pint, 15 cts.; quart, 30 cts.; peck, $\$ 1.50$; bushel

PRIDE OF THE MARKET-A strong growing variety, growing from 18 to 24 inches high, and is very productive. The pods are unusually large, and the Peas, when cooked, are of very superior quality. Pkt., 5 ets.; pint, 15 cts.; quart, 30 cts. ; peck, $\$ 1.60$; bushel.

*McLEAN'S ADVANCER-An excellent variety of very fine flayor; 2 feet. Pkt., 5 cts. ; pint, 15 cts.; quart, 25 cts.; peck, $\$ 1.25$; bushel . . ....4.50

* CHAMPION OF ENGLAND-One of the best and most popular Peas in cultivation; 5 feet. Pkt., 5 cte. ; pint, 10 cts. ; quart, 20 cts.; peck, $\$ 1.00$; bushel ...

*TELEPHONE-Vines very strong, averaging 18 to 20 pods to a plant. It branches considerably, the branches bearing from three to five pods. The pods average six to seven large wrinkled seeds of the first quality. Pkt., 5 cts. ; pint, 15 cts. ; quart, $30 \mathrm{cts.;} \mathrm{peck,} \$ 1.50$; bushe1..............6.

-TELEGRAPH-A very prolific sort, iproducing large; well-filled pods. Vines strong. Peas deep-green and of very fine flavor. Pkt., 5 cts.; pint, 15 cts.; quart, 30 cts.; peck, $\$ 1.50$; bushel......................6.0

Blue Imperial-An old favorite. Very productive and of good flavor. Pkt., 5 cts. ; pint, 15 cts. ; quart, 25 cts.; peck, $\$ 1.25$; bushel.............. 3.50

*Laxton's Omega-Very prolific, of fine flavor and good color when cooked; 21/2 feet. Pkt., 5 cts.; pint, 15 cts.; quart, 30 cts. ; peck, $\$ 1.50$; bushel.

White Marrowfat-A favorite sort; 4 feet. Pkt., 5 cts.; pint, 10 cts. quart, $20 \mathrm{cts}$; peck, $75 \mathrm{cts}$; bushel. .

Black-Eyed Marrowfat-This, as well as the preceding, is extensively grown as a Field Pea; hardy and productive; 4 feet. Plt., 5 cts.; pint, 10 cte.; quart, 20 cts.; peck, 75 cts.; bushel..........................2.2

Dwarf Sugar, Fdible Pods-Grows about two feet high, and is remarkable for its earliness as well as its prolific character. Pkt., 5 cts.; pint, 15 cts.; quart, 25 cts, ; peck, $\$ 2.00$; buahel.

\section{Those marked thus * are wrinkled.}

\section{FIELD SORTS.}

Canadian White Field-Pint, $10 \mathrm{cts}$; quart, 15 cts.; bushel..........1.35 Blue Field-Pint, $10 \mathrm{cts}$; quart, 15 cts.; bushel............. Scotch Peas-Pint, 10 cts.; quart, 15 cts.; bushel.....................1.50 Field Peas subject to market fluctuation. Write for prices.

\section{PARSNIPS.}

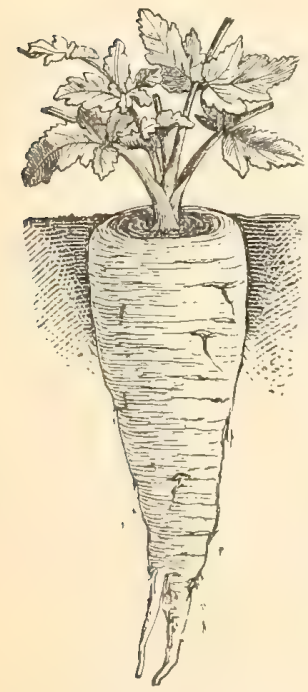

\section{German, Pastinake. French, Panais.}

Sow in spring as early as the weather will admit in drills fifteen inches apart and half an inch deep. When well up, thin out to 5 or 6 inches apart. Unlike Carrots, they are improved by frost, and it is usual to take a quantity in the fall for winter use, leaving the rest in the gronnd until epring, to be dug up as required.

If by mail in quantities of $1 / 2 u$. and up. wards, postage must be addedat the rate of 8 cts. per $l b$.

1 oz. to 150 feet of drill; 34 to 6 lbs. peracre in $d r^{i} i l l s$.

LONG SMOOTH, or HOLLOW CROWN -The favorite variety and best for general use. Pkt., 5 cts.; oz., 10 cts.; 1//4 1b., 20 cts.; 1 lb.... .50 Student-Not so generally used as the preceding, fbat by many highly esteemed. Pkt., 5 cts.; Oz, 10 cts, ; $1 / 3$ lb, 20 cts.; $1 \mathrm{lb}$.

GUERNSEY-(Improved Half Long)-An im$L$ provement on the old Hollow Crown, forming roots shorter and thicker than that variety. It is a large cropper, very smooth, and the flesh is fine-grained and of excellent quality. Pkt., 5 cts.; oz, 10 ets.; $1 / 4$ lb.. 20 cts.; $11 \mathrm{~b} \ldots . . . . . . . . . . .50$
PUMPKIN.

German, Kuerbis French, Courge.

Principally cultivated for agricultural purposes. They are asually planted in fields of Corn or Potatoes. Sow 1st of May in hills 8 feet apart.

If by mail in quantities of $1 / 2$ lb. and uproards, postage must be added at the rute of $8 \mathrm{cts}$. per $\mathrm{lb}$.

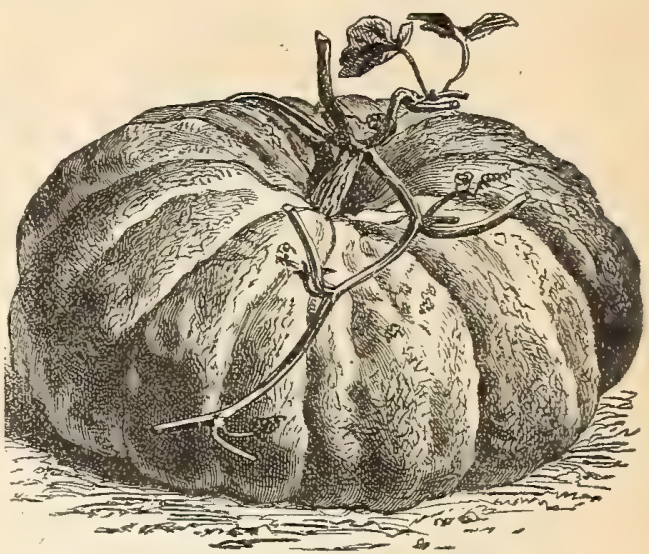

1 oz. to $40 \mathrm{hills} ; 3$ to $4 \mathrm{lbs}$. per acre.

JONATHAN-One of the finest cooking varieties; a good keeper; very prolific. Pkt., 5 cts. ; oz., 10 cts. ; 1/4 lb., 25 cts.; 1 lb.................. . .75 LARGE CHEESE-The best variety for cooking purposes. Pkt., 5 cts.; oz., 10 cts.; $1 / 4$ Ib., 20 cts.; 1 lb .45 SUGAR-A fine-grained variety, smaller than the Field, but very prolific.

Pkt., 5 cts.; oz., 10 cts.; 1/4 1b., 20 cts.; 1 lb........................... 45

NEGRO, or NANTUCKET-An old but very prolifle sort; the shell is dark green with black warts, and very hard. Pkt., 5 cts.; oz., 10 ct8.; $1 / 4$ lb., 25 cts.; 1 lb............................................. .70 MAMMOTH TOURS-An imported variety. Grows to an immenes size. Pkt., 5 cts.; oz., 10 cts. ; $1 / 4$ lb., 20 cts.; 1 lb........................... 65 JUMBO-The largest of all Pumpking, often weighing 200 lbs. Pkt, 10 cts. ; oz., 25 cts.; 1/4 lb., 60 cts.; 1 lb...............................2.00 Connecticut Field-Very productive; largely grown for feeding stock.

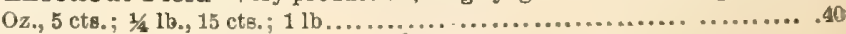

\section{SALSIFY, OR OYSTER PLANT. German, Bockbbart. French, Salsifis,}

Grows best in light, well:enriched soil, which, previous to sowing the seed, should be dug up to a depth of 18 inches. Sow early in spring, in drills 15 inches apart and 1 多 iaches deep, and when the plants are strong enough, thin out to 6 inches apart.

If by mail in quantities of $1 / 2 \mathrm{lb}$. and upwards, postage must be added at the rate of 8 cts. per $l b$.

1 oz. to 70 feet of drill.

Large White-Pkt., 5 cts.; oz., 15 ct.9.; 1/4 lb., 30 cts.; $1 \mathrm{lb} \ldots \ldots \ldots \ldots \ldots \ldots \ldots \ldots \ldots . . . \ldots$ MAMMOTH SANOWICH ISLAND-A new and large growing variety, of great value to the market gardener, Pkt., 5 cte. ; oz., 15 cts. ; 1/4 lb., 40 cts ; 1 lb........... 1.30

\section{SCORZONERA, OR BLACK OYSTER PLANT.}

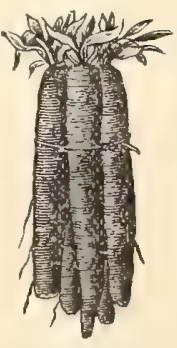

Requires the same treatment as Saleify, which it nearly resembles. Sow in drille 18 inches apart and thin ont to 9 inches between the plants. Plit., 5 cts. ; 0z., 15 ctв.; $1 / 2$ lb., 40 cts. ; $11 \mathrm{~b} . . . \ldots . . . . . . .1 .20$

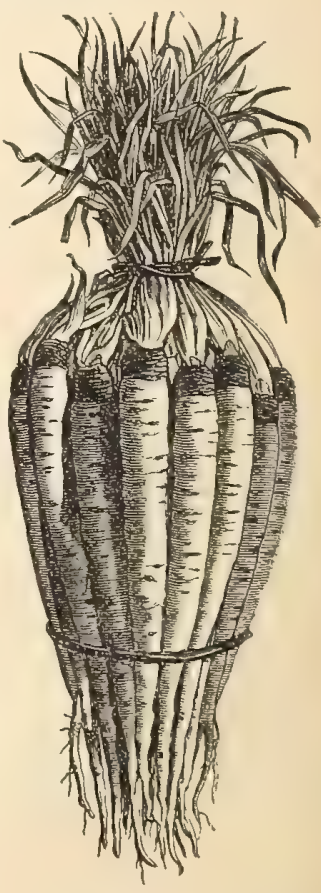

\section{SEA-KALE.}

German, Seekohl, Meerkohl. BaLbIFY, OR orster PLAIT?. French, Crambe Maritime.

SCORZONERA, 'Grown for its blanched shoots, which are cooked as AsparaOR BLACK J gue. By planting the roots closely in a warm cellar, orSTER PLANT. Gf a supply may be had all winter. Sow in drille 2 feet apart, thin out to six inches, and the following spring plant in hille 8 feet apart. Pkt., $10 \mathrm{cts}$; oz., $30 \mathrm{cts}$; $1 / 4 \mathrm{lb} ., \$ 1.00 ; 1 \mathrm{lb} . . . . . . . . . . . . .3 .56$ 


\section{POTATO.}

\section{German, Kartoffel. French, Pomme de Terre.}

The Potato may be grown with varying anccess on soils of all kinds, but the soll best suited to it is sandy loam. Bat little manure is required if the soil is good.

\section{0 bushels cut tubers to the acre.}

The Potatoes we offer are specially raised for ue for seed purposes. We deliver all Potatoes f. o. b. cars, no extra charge being made for barrele. All Potatoes are shipped at purchaser's riek.

\section{Prices of all Potatoes subject to variation.}

\section{CREAM CITY-Compared with many excellent Potatoes grown alongeide} of the Cream City, it has yielded almoet double the quantity of tubers, snd not only did it produce more, but the Potatoes were all of a very superior quality, and not in any case did it show a disposition to decay or blemish, so prevalent among Potatoes in many parts of the country. It Is the best early Potalo we have ever seen. In habit of growth and general appearanceit resembles the Early Ohio, with this decided difference, however, that while the abape is almost identical with that very popular variety, the flesh is pure white. The tubers grow to a large size, but are always sound and solid, showing no diaposition whatever to become hollow. They are matured very early, and are of excellent quality, and cook remarkably quick, and are invariably most delightfully dry and fiaky, very much like that old favorite, Snew flake. And not the least of its many good qualities is its remarkable productiveness. As a keeper it is unsur. passed. Peck, 75 cts.; bushel, $\$ 2.00 ;$ bbl. ......................... $\$ 5.0$

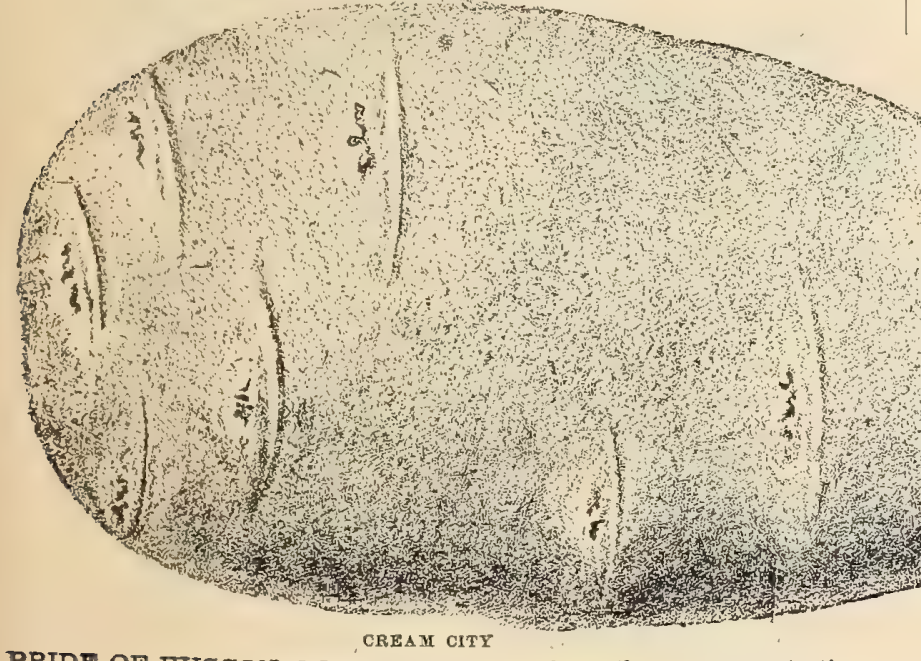

PRIDE OF WISCONSIN-We fully realize from the numerous testimonials we have received, that in this Potato we possess a variety of very superior merit indeed. Every letter we receive testifies to the remarkable size and beauty of the tubers, which are oblong, round and smooth, and of a beautiful rose color; and also corroborates what we said regarding its great productiveness and excellent shipping and household qualities, and fine flaror. For good keeping qualities it has no superior. Peck,

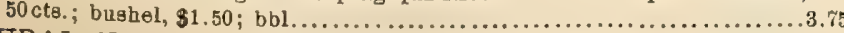

RURAL NEW YORKER, No. 2 -An intermediate variety of robust habit, and a very abundant yielder, producing large well-shaped tubers of slightly oblong shape and very uniform in size. The skin is white and smooth with few and shallow eyes. Peck, 50 cts.; bushel..........1.50

MONROE SEEDLING-An excellent medium early variety. It is a strong grower, tubers large, very uniform in size and very productive. In form it is oblong and eomewhat flat. The skin and flesh are white; cooks mealy and of very fine flavor. Peck, 50 cts.; bushel,... .............

Early Oblo-One of the best early eorts. Peck, 35 cts.; bushel, $\$ 1.40$;

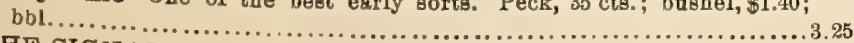

TEE SIGNAL-An esrly Potato, dimilar in shape to the Beauty of Hebron. It is a large yielder, strong grower and a good cooker; color nearly white. Pkt, 50 cts.; bushel, 81.50 ; bbls........................

Beauty of Hebron-One of the best early varieties, of vigorous growth and very prodactive. The tubere are similar in shape to the Early Rose, and of the finest quality. Peck, 85 cts.; bushel, $\$ 1.40 ;$ bbl..............25

FARLY PURITAN-In earliness equal to Early Rose, but superior to that old favorite, inasmuch as while its tubers are still quite young they are dry and fit for table use. It is a good yielder and of flne quality; skin and flesh white. Peck, s0 cts.; bushel...............................50

White Star-A good main crop variety, large yielder, good keoper and excellent cooking qualities. Peck, 50 cts.; bushel, $\$ 1.40 ;$ bbl.............2.25
THE KOSHKONONG-A medium early Potato, producing a heavy crop of large tubers, which resemble the EARLY PEARL-An earlyvariety, produclng largely on rich, clayey soil The tubers do not grow to a very large size, hut is a heavy cropper. Its
cooking qualitiea are first-class. Peck, $50 \mathrm{cts}$; ; bushel, $\$ 1.50 ; \mathrm{bbl} . . . . . .3$.

\section{See four new Potatoes, page 6.}

\section{RHUBARB.}

German, Rhabarber. French, Rhubarbe.

Sow in April, in drills 1 foot apart, thinning out to about the same distance apart in the rowe when a few inches high. Traneplant into deep, rich soil in fal or the following spring, about 3 feet apart each way. If propagated by dividing the roots, it may be done either in fall or spring.

If by mail in quantities of $1 / 27 b$. and upwards, postage must be added at the rate of $8 \mathrm{c}$. per $l b$. Linnæus-Early, large and tender. Pkt, 5 cte. ;

oz., 15 cts.; $1 / 4$ lb., 40 cts. ; 1 lb .............1.25

Victoria-Very large; later than Linnæus. Pkt., 5 cts.; oz., 15 cts.; $3 / 6$

lb., 40 cts.; 1 lb............................................ $\$ 1.25$

RHUBARB ROOTS-10 cts. each; per dozen...................... 00

\section{SPINACH.}

German, Spinat. French, Epinard.

This is one of the most important of our market garden crops, and one that requires very little care. For summer use sow at intervals of 2 or 3 weeks from. April to August, and for winter crop sow in September, covering it, in exposed places, with straw, to protect it from the severe frost. Spinach succeeds best in a rich soil.

If by mail in quantities of $1 / 2 \mathrm{lb}$. and uproards, postage must be added at the rate of $8 \mathrm{cts}$. per $1 b$. $10 z$. to $75 \mathrm{ft}$. of drill. $10 \mathrm{lbs}$. to the acre in drills.

Special prices for large quantities.

Round Lerf-The main market sort; equally good for spring or fall sowing. Oz., 5 cts.; $1 / 4$ lb., 15 cts.; 1 $1 \mathrm{~b}$

ROUND THICK-LEAVED-Similar to the RoundLeaf, but thicker leaved; very tender. Oz, 5 cte.; $3 / 4$

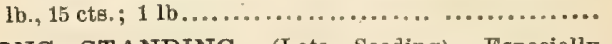

LONG STANDING - (Late Seeding) - Especially deirable from the fact that it is much later in going to seed than the older varieties. Oz, 5 cts.; $1 / 4 \mathrm{lb}$., $15 \mathrm{cts} ., 1$ $1 \mathrm{~b} .$.

CARTER'S MARKET FAVORITE-An improvement on the older sorts, like Long Standing, remaining in full condition for use after other varieties have run to seed. Pkt., 5 cts.; oz., $10 \mathrm{cts}$; $1 / 1 / \mathrm{lb}$ $15 \mathrm{cts}$; $11 \mathrm{lb}$.

ROUND LFAF VIROFLAY-A variety with large, thick leaves. Oz., 5 cts.; $1 / 4$ lb., 15 ets.; 1 lb............. Bloomsdale Savoy LeavedThe leaves are wrinkled, resembling those of the Savoy Cabbage. Pkt., 5 cts.; oz., 10 cts.; $1 / 4 \mathrm{lb}, 15 \mathrm{cts} ; 1 \mathrm{lb}$

Prickly-Stands the winter well, but gives less bulk than the Round Leaf. Oz., 5 cts.; $2 / 4 \mathrm{lb}$. 15 cts. $; 1 \mathrm{lb}$

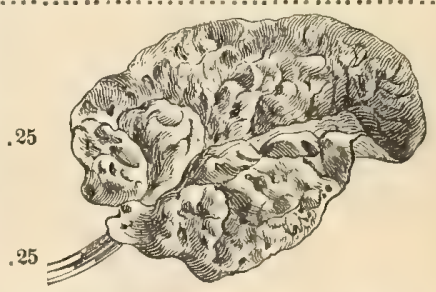

All of the above varieties in $10 \mathrm{lb}$. lots at 15 cts. por lb.

New ZэalandThis plant grows very large and Iuxuriant in warm, rich soil. It will endure severe drought, which is its greatest advantage, and produces a I arge quantity of leaves

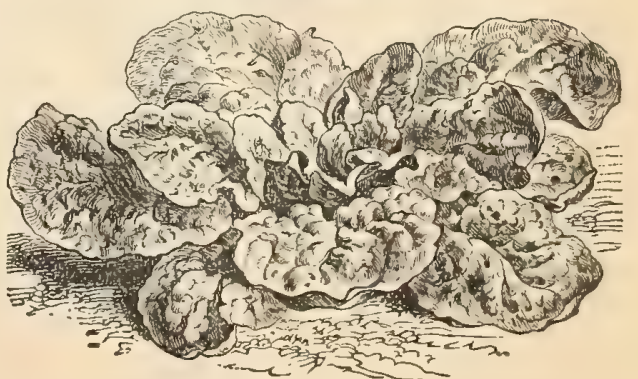

BLOONSDALE SPINACH. during summer. The plants should stand two or three feet spart. Pkt.

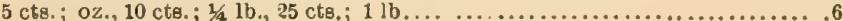




\section{RADISH.}

German, Rettig, Radieschen. French, Radis, Rave, Petite Rave.

Rsdishes do best in a light, sandy soil. For a successive supply, sow from the midale of March until September, at intervals of two or three weeks. They may be sown in a hot-bed for an early supply.

If by mail in quantities of $1 / 2 \mathrm{lb}$. and uproards, postage must be added at the rate of $8 \mathrm{cts}$. per $1 b$.

$10 z$. to 100 feet of drill ; 8 to $10 \mathrm{lbs}$. per acre in drill.

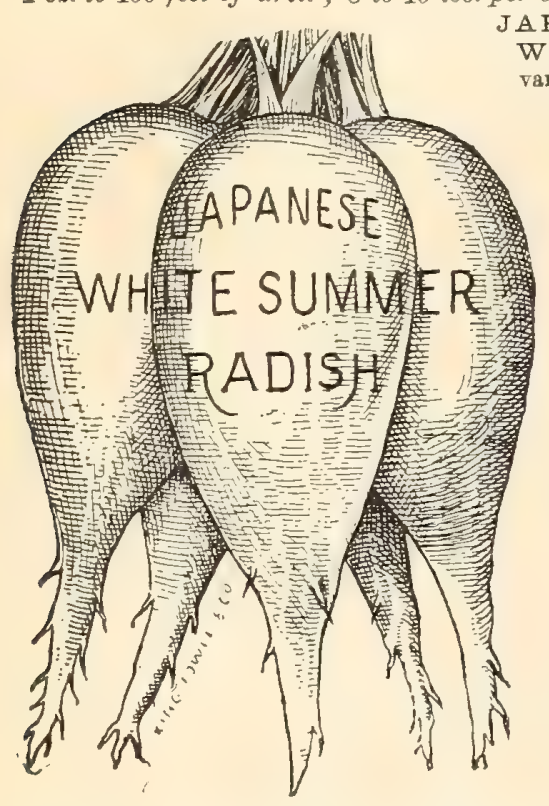

APANESE LONG W EITE-A new summer variety of excellent quali. ty. It resembles the Strasburg in many respects,growing about the same size, snowwhite and smooth. The flesh is remark ably crisp and tender, and of the most delicions flsvor. Comes into use early in the season, and is equally as good for a late crop. Ite beautifal appearance, c o mbined with the many other finelqualities it possesses, make it invaluable. Pkt., 5 cts. oz., 15 cte.; $1 / 4$, lb., 35 cts.: $1 \mathrm{lb} . . . . . . . . \$ 1.25$

NON PLUS ULTRA The earllest of all forcing Radishes, coming into use with in 3 weeks after sowing. The roote are ronnd, color bright scarlet, flesh tender and very delicate, leavesivery omsll. Pkt., 5 cts.; oz. 10jcts.; 1/4 lb., 30 cts.; $1 \mathrm{lb} .$.

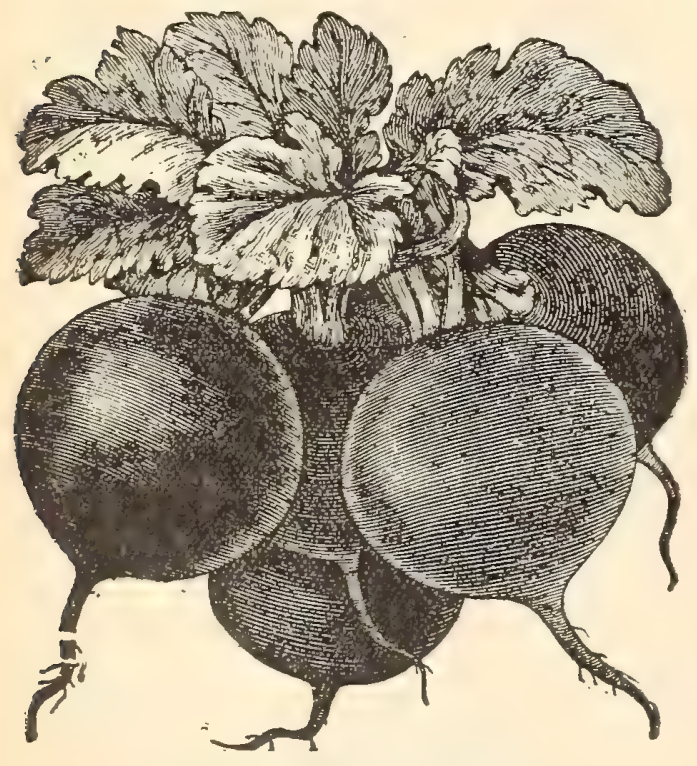

EARLIEST SCARLET GLOBE. A new forcIng gort of e finest guality. Col or brilliant red, emallleaved, flesh finest white, tender and crisp. Pkt, 5 cts.; oz., $10 \mathrm{ctg}, ; 1 / 4 \mathrm{lb}$. 25 cts. $; 1$ 1b. 6 EARLIEST CARMINE FORCING. An excellen forcing variety, $8 \mathrm{hort}$ leaved, deep scarlet, olive shaped, very tender. Plt. 5 cts.; oz , 10 cts. ; 1/4 lb., 25 cts.; $11 \mathrm{lb}, .65$

SCARLET TURNIP-The standard variety for market. Pkt., 5 cts.; oz.,

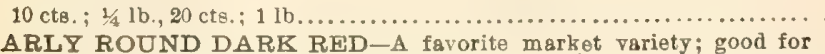
forcing. Pkt., 5 ct $8, ; 0 z, 10 \mathrm{cle} ; 1 / 4 \mathrm{lb}, 2) \mathrm{ctg}, ; 1 \mathrm{lb}$. .

WEITE TIPPED SCARLET TURNIP-An early variety of medium size and very hands sme appearance. Pkt, 5 cte, ; oz., 10 cts.; $1 / 4$ lb., 20 cte. ; $1 \mathrm{lb}$.

WHITE SUMMER TURNIP-Excellent for gummer nse; mild, Pkt., 5 cts.; oz., 10 cts.; 2/4 lb., 20 cts.; 1 lb.

YELLOW SUMMER TURNIP-A large-sized sort; excellent to stand the hest and drought of summer. Pkt., 5 cts.; oz., $10 \mathrm{cts}$; ; 1/4 lb., 20 cts. ; 1 lb .50
FELTON'S MODEL WHITE BOX-An improvement on the Philsdel phia White Box Radish. This new variety poesesses all the good qualsties of Philadelphia White Bor and $\mathrm{h} s$ s the further meris of being earlier, rounder in shape, handsomer in appesrance and has finer and chorter leaves, thereby enabling the grower to raise at least one-thire more Radishes in the same space. Pkt., $10 \mathrm{cts} . ;$ oz., $15 \mathrm{ct3}$. ; 1/4 lb., $35 \mathrm{cts}$; 1 lb...\$1.00

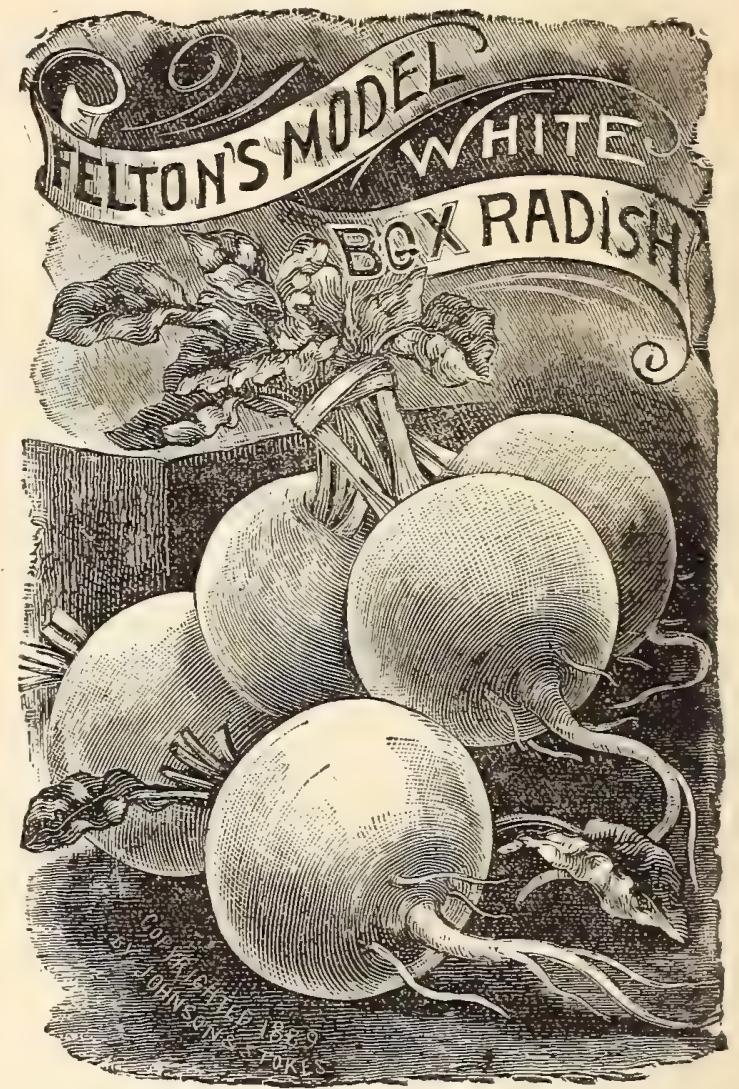

GRAY SUMMER TURNIP-A good summer variety. Pkt., 5 cts,; $\mathbf{O z}_{\text {, }}$

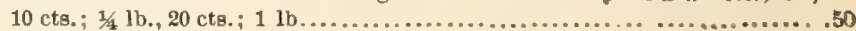
GOLDEN GLOBE-Of particnlarly fine flavor, very early, and well adapted for either forcing or open ground culture, Pkt, 5 cts.; 0z., 10

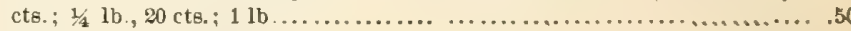
WHITE OLIVE-SHAPED-A valuable forcing variety, Pkt, 5 ots.; FRENCH BREAKFAST-Of quick growth; rery mild and tender. Pkt., $5 \mathrm{cts}$, ; oz., $10 \mathrm{cts}$; $1 / 4 \mathrm{lb} ., 20 \mathrm{cts}$; $1 \mathrm{lb} . \ldots \ldots \ldots \ldots \ldots \ldots \ldots \ldots \ldots \ldots . . . \ldots 5$ GRAY OLIVE-SHAPED-A good variety for summer. Fkt, כ ets.; oz.,

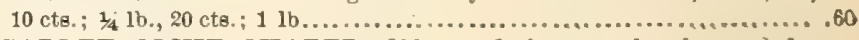
SCARLET OLIVE SHAPED-Oblong; flesh rose-eolored; geod for

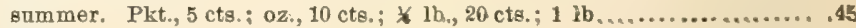
Wood's Early Frame-Good for forcing. Pkt, 5 cts.; 08, 10 cte. ; 敞

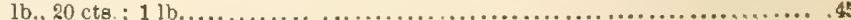

Long Scarlet Short Top-A favorite variety for private gardene. Pkt., 5 cts.; oz., 10 cts, ; $1 / 41$ b., 20 cts.; 1 lb........................... .43. BECKERT'S CHARTIER-An attractive and diletinet long varlety. Grows to a large size, and very tender. Color at the top bright crimeon, ehading to pink at the middle, and ranning to pure white at the tip. Pkt., 5 cts. ; oz., 10 cts.; 1/4 1b., 20 cts. ; 1 lb.......................... 50 STRASBURG, or HOSPITAL-A popular half-long white vartety, of fine flavor. Matures quickly, and is a good keeper. Ptkt, 5 ets,; $0 x_{\text {, }} 10$

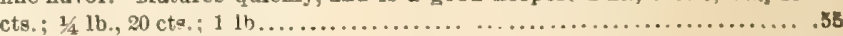
LONG BLACK SPANISH-One of the best for winter use. Pkt, $5 \mathrm{cts}$.;

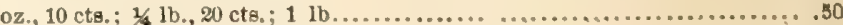

Round Black Spanish-Pkt., $5 \mathrm{cts}$; $08,10 \mathrm{cts}$; $341 \mathrm{lb}, 20 \mathrm{cts}$; \$ $1 \mathrm{~b} . . . .50$ GRAY LONG WINTER-A tine winter varlety; grows somewhat larger than the Black Spaniah; good keeper. Pkt., 5 ots, oz., 10 otes; $x_{4} 1 \mathrm{~b}, 20$

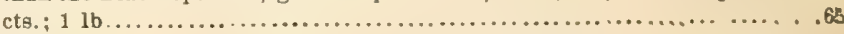
ROSE CHINA WINTER-Bright rose color; flesh firm; excellent for

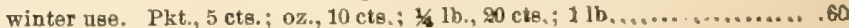
CALIFORNIA MAMMOTH-A very large white whter Radibl of ex. cellent quality. Pkt., 5 cte.; oz., 10 cts.; $1 / 4$ lb., 25 cts, ; $11 \mathrm{~b} \ldots . . . . . . . . . . . .65$ Write for special pricfs on large quantities. 


\section{_urrip Bros.' Hortieultural Guide.—_ _ _ _}

\section{SQUASH.}

German, Kuchen-Kürbis. French, Courge.

Sow in hills in well-prepared ground, mixing twotor three ehovelfuls of wellrotted manare in each hill. Light enila sre best suited to their growth. Plant

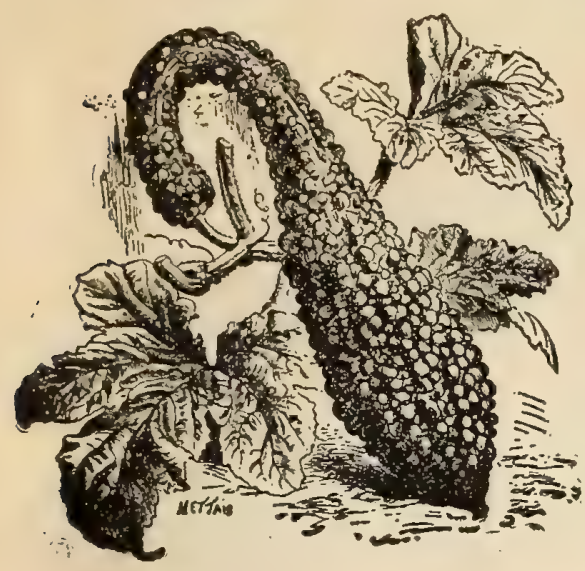
six to eight seeds in esch hill and thin out to three or four after they have made partial growth. Plant Bush varieties from three to four feet apart each way, and the Trailing sorts six to eight feet.

If by mail in quantities of $1 / 2 l b$. and up wards, postage must be added at the rate of 8 cts. per $l b$.

Early Squash, 1 oz. to 50 hills, 5 to 6 lbs. to the acre.

Marrow Squash, 1 oz. to 20 hills, 3 to 4 lbs. GLAYT SUMMER CROOK NECK. to the acre.

SUMMER SQUASHES.

GOLDEN CUSTARD BUSH-A very productive early scalloped sort. Color rich golden yellow. Quality excellent. Pkt., 5 cts.; oz., 10 cts.;

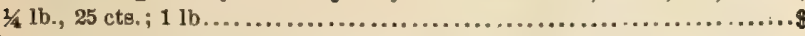

GIANT SUMMER CROOK NECK-This variety matures fully as early ss the common Crook Neck, while the Squashes grow to a much larger size, usually measuring from 18 to 24 inches in length, and is of the finest quality. Pkt., 5 cts.: oz., 10 cts.; $1 / 41$ lb., 25 cts; 1 lb...

Bush Summer Crook Neck-An early and productive sort, and of good quality; fruit orange-yellow, covered with warty excrescences. Pkt., 5 cte; oz , 10 cts.; 1/4 lb., 20 cts.; 1 lb.

White Bush Scalloped-An early variety, excellent for shipping. Pkt. 5 cts.; oz., 10 cte.; 1/4 lb., 20 cts.; 1 lb.................

EGG PLANT SQUASE-A very early Bush variety, resembling the Egg Plant in shape and flavor when cooked. The fleah is white. Pkt., 5 cts.; oz., 10 cts. ; $1 / 4$ lb., 25 cts. ; 1 lb...

\section{FALL OR WINTER SQUASHES.}

FORDEOOK-One of the earliest Winter Squashes, a good yielder and an excellent keeper. Pkt, 5 cts.; oz., 10 cts.; $1 / 4$ lb., 30 cts.; $1 \mathrm{lb} . . . . . . . . . .11 .00$ VALPARAISO -A large grower of fine quality and very productive. Pkt.,

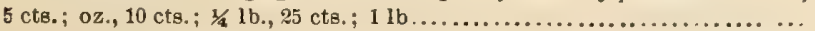

HARLY PROLIFIC MARROW-A valuable sort, growing to a good size. Althongh it begins to ripen early, it continues to bear until killed by frost. It is a strong grower, and very prolific; the rind is a deep cream, elightly ribbed; flesh white, turning to light cream as it ripens; of excellent quality. Pkt., 5 cts.; oz., 10 cts.; $x$ lb., 20 cts. : $1 \mathrm{lb} \ldots \ldots . . . . . . . . .$.
Perfect Gem -

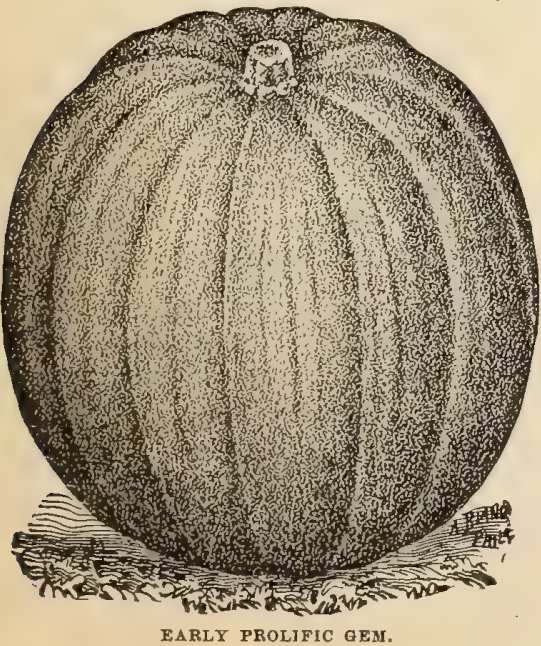
markable variety, inasmuch as it is equally desirable either as a summer or winter Squash, and possessing the best features of both classes. It is a splendid keeper. Pkt., 5 cts.; oz, 10 cts.; $1 / 2 \mathrm{lb}$., $20 \mathrm{cts}$; 1 Ib

BAY STATE-This new gort is a valuable acquisition. It is more prolific than the Hubhard, is larger on the average, and is by $f a r$ much thicker fleshed. The quality is as much finer than the Hubbard 88 the Hubbard is superior to the old Mar

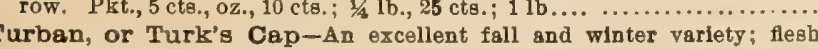
orange-colored, fine-grained, and of good flavor. Pkt., 5 cte.; oz., 10 cte.

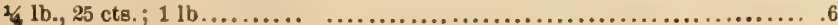

Boston Marrow-A valuable variety, coming in about ten daye later than the Bush eorts; a good keeper and of fine flavor. Pkt., 5 cte.; oz, 10 cts $1 / 4$ lb., 20 cts. : $1 \mathrm{lb}$ $\$ .50$

HUBBARD -A fayorite and late sort and more largely grown than any other: of large gize; fieah fine-grained, dry, and of excellent flavor. Pkt.

5 cts.: 02., 10 cts.; 1/4 1b., 25

cts. ; $1 \mathrm{lb} . \ldots . .$. . 65

SIBLEY-A splendid variety, ripening at the same time as the Hubbard; outside s $\mathrm{h}$ ell pale green; flesh bright orange Pkt, 5 cts.; oz., $10 \mathrm{cte}$; $1 / 4 \mathrm{lb}, 25$ cts. : $1 \mathrm{lb} \ldots . .$. .

Essex Hybrid -An early and rapid growing variety, with thick rich-colored solid flesh of the richest flavor; it is also

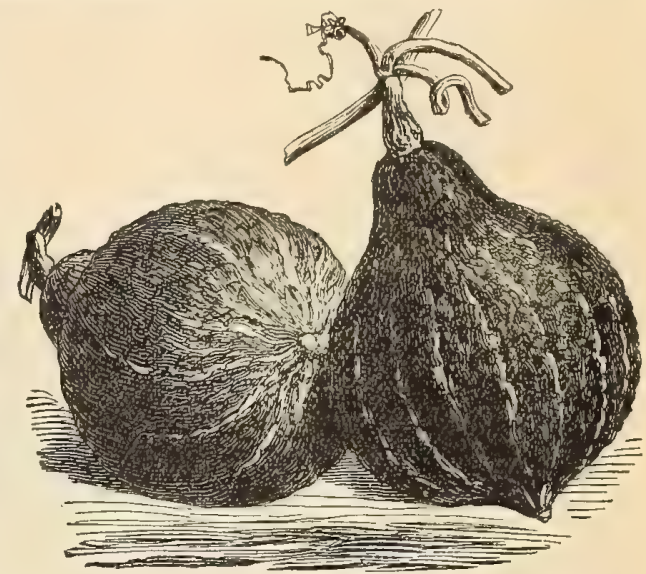

HUBBARD one of the best keepers. Pkt., 5 cts.; oz., 10 cts.; $1 / 4$ lb., 25 cts.; 1 lb.. ... .65

MARBLEHEAD-A very fine late variety, resembling the Hubbard, only that the flesh is a little lighter than that variety. It is a fine yielder and a splendid keeper. Pkt., 5 cts.; oz., $10 \mathrm{cts} . ; 1 / 4$ lb., $25 \mathrm{cts} . ; 1 \mathrm{lb}$.

Winter Crook Neck-A good fall variety; flesh close-grained and sweet. Plant nine feet apart. Pkt., 5 cts.; oz., $10 \mathrm{cts}$; $2 / 4$ lb., 25 cts.; 1 lb........ .65 Cocoanut-A very prolific variety of fine quality; flesh tine-grained and solid. Pkt., 5 cte,; oz., 10 cts.; $\times 1$ lb., 25 cts.; $1 \mathrm{lb}$.

White Fineapple - A new turban shaped varlety ripening about the same time as Perfect Gem, but can be used earlier in the season, being of excellent quality when quite young. It is a strong grower and very prolific. The flesh is creamy white and of fine quality. Pkt., 5 cts. oz., 10 cts. ; 米 1b., 20 cts. $1 \mathrm{lb} . . . . . . . .$.

Butman - A variety in size and productiveness resembling the $\mathrm{Hub}$ bard; flesh fine-grained, lemon-colored, and of excellent flavor. Pkt., 5 cts.; oz., 10 cts.; $1 / 4$ 1b., 25 cte. ; 11 b............ . MAMMOTH CHILI-Grows to a very large size, often weighing over 200 lbs. Pkt., 5 cts.; oz, 10 cts.; $1 / 4$ lb., 30 cts.; 1 ib...................... 1.00

Vegetable Marrow-A variety used extensively in England. The fruit is oblong, with a greenish-yellow skin; flesh white, soft and of excellent flavor. Pkt., 5 cts. ; oz., 15 cts.; 1/4 lb., 40 cts. ; $1 \mathrm{lb}$

\section{SORREL.}

B road-L $\theta$ a $\nabla$ ed. Used for salads. Pkt. 5 cts. ; oz., 15 cts. : $1 / 4$ lb., 40 cts.; 1 lb...\$1.00

SUNFLOWER, Helianthus.

Grown especisily for its seed, which is good poultry feed. The leaves are slso used for for age.

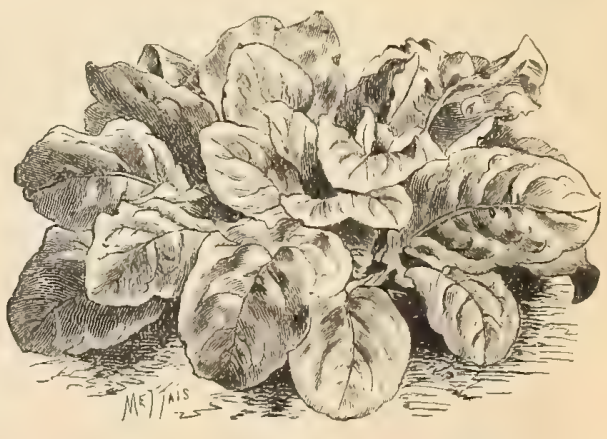

If by mail in quantities of $1 / 2 l b$. and upwards, postage must be added at the rate of $8 \mathrm{cts}$. per $\mathrm{lb}$.

Large Russian.-Pkt., 5 cts, ; oz., 10 cts.; 1/4 lb., 15 cts.; 1 lb., 25 cte.; 10 lbs. 1.50 See Flower Seed List for Garden Varieties. 


\section{TOMATO.}

German, Liebesapfel. French, Tomato.

Sow the seed in a hot-bed first week in March, in drills half an inch deep. When the plants are about 2 inches high transplant into another hot-bed or into small pots, one plant in each pot; in that way the plants are strengthened and branch out better. Set the plants out about the first of June, about 3 feet apart, for early crop, mixing a shovelful of well-rotted manure in each hill. For late crops, or where the ooil is heavy, plant 4 feet apart. Water freely when trans. planting, and protect from eun for a few days until the plants are fairly etarted. A few plants may be raised by sowing seed in a pot or a box in the house.

If by mail in quantities of $1 / 2 l b$. and upwards, postage must be

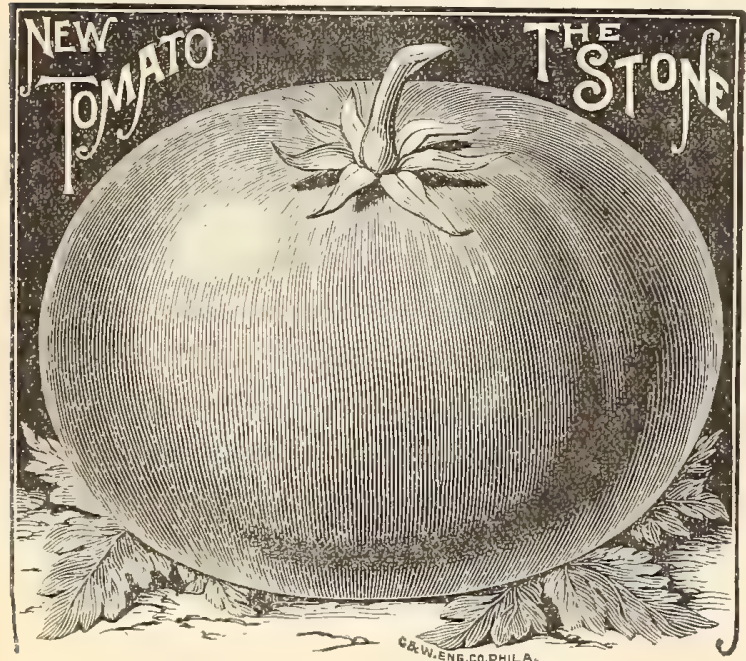

added at the rate of cts. per

1 oz. to 1,500 plants ; $1 / 4$ lb. for transplanting on an acre.

N TW STONE TOMATO-The New Stone Tomato ripens for main crop; is very large and of bright acarlet color, very smooth, with occasionally a specimen very elightly octagon-ehaped, ripening evenly to the stem without a crack; exceedingly solid and firm fleshed; not subject to rot. Pkt., 5 ct8.; 0z., 35 ct8.; 话 lb., \$1.00; $1 \mathrm{lb}$.

THE LORILLARD-The shape is round, smooth and clean cut, and the color is a beautiful vermilion acarlet. It is very prolific, and bears fruit of a good size; very solid and of excellent flavor. Pkt., 5 cts,; oz., 30

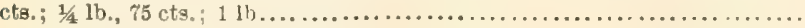

DWARF CFIAMPION-Differs from any other in its style of growth, being dwarf and more compact. It is very early and remarkably productive. As much as half a bushel of fruit has been picked from one plant at a time. The fruit is a purplish pink color, round and smooth; flesh solid and of fine quality. Pkt., 5 cts.; oz., 25 cto.; 1/4 1b., 75

$\begin{aligned} & \text { cts. } 1 \mathrm{lb} \ldots \ldots \ldots \ldots \ldots \ldots \ldots \ldots \ldots \ldots \ldots \ldots \ldots \ldots \ldots \ldots \ldots \ldots \ldots \ldots \ldots \ldots \ldots \ldots \ldots \ldots \ldots \ldots \\ &\end{aligned}$ ive; flesh solid. Pkt, $10 \mathrm{cts}$; oz., $40 \mathrm{cts}$; 1/4lb., $\$ 1.00 ; 1 \mathrm{lb}$.

LIVINGSTON'S FAVORITE-Ripens evenly and as early as any good variety, holding its eize to the end of the season; very prolific, good flevor, few seede, flesh solid. Pkt., 5 cts.; oz., 20 cte; ; 1/4 lb., 60 cts.; 1 lb.1.85

Mayflower-One of the earliest; large, round and smooth; color brilliant red; a good yielder, ripens evenly and is an excellent keeper. Pkt., 5 cts.;

oz., 25 cts. ; $1 / 4 \mathrm{lb}, 75$ cts. ; $1 \mathrm{lb}$....

EARLY RUBY - The introducer of this variety claims that it is by far the earliest of all the large-sized Tomatoes now grown. and that it is likely to supersede all early sorts. Pkt., 5 cts.; oz., 35 cts.; $1 / 4$ lb., $\$ 1.00 ; 1 \mathrm{lb} .4 .00$

ACME-This is one of the earkiest and handsomest varieties yet introduced. The fruit is of a medium eize, perfectly smooth and regular in shape, very solid and a great bearer; color dark-red with purplish tint. Pkt, 5 cts.

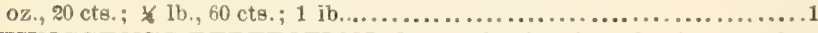

LIVINGSTON'S PERFECTION-Larger in size than the Acme; color blood red; it is one of the first to ripen; almost round in shape, perfectly smooth and very solid; of the best quality; enormously productive. Pkt.

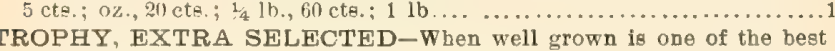

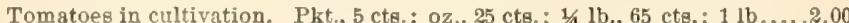
OPTIMUS - An early smooth variety of bright-red color; ripens evenly and is very uniform in shape and eize; flesh solid and of good lavor. Pkt., 5

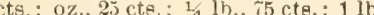

THE MIKADO-(Turner's Hybrid) - A variety of very large size and superior quality. Color purplish-red; perfectly solid, produced in immense clustere. It is one of the moet desirable market varieties. Pkt. 5 cte.; oz. 25 cts.; $1 / 4$ lb., 65 cts.; $1 \mathrm{lb}$
PEACH-A distinct sort resembling a Peach in size and shape, and the color is a deep rose, blended with amber and covered with that delicate bloom peculiar to the Peach. Pkt., 5 cts.; oz., 25 cts.; $1 / 2$ lb., 75 cts.; 1 lb. $\$ 2.25$ YELLOW PEACH TOMATO-This is the exact connterpart of the older sort, except in color, which is a deep lemon-yellow. It has the same soft leathery skin, which is such a distinguishing feature of the Peach variety, and is equally desirable for cooking purposes. Pkt., 5 cts.; oz., 25 cts.

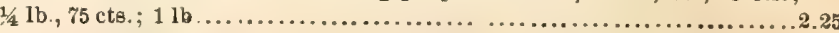

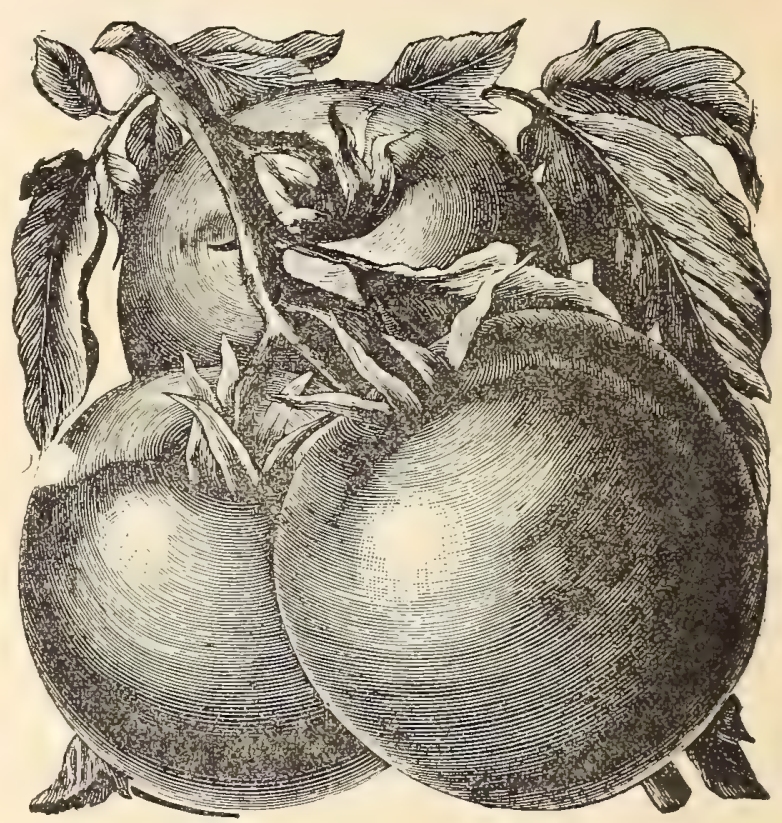

PEACH TOMATO.

LIVINGSTON'S BEAOTY-A very fine variety of large size; grows in clueters of four or five; color glossy crimeon with a purplish tinge. Very solid with a tough akin, making it a desirable market variety. Pkt., 5 cts.;

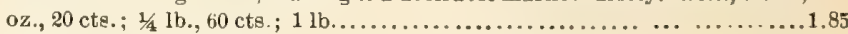
THE CARDINA L-Bright red, of fine quality, round and solid. Pkt., 5

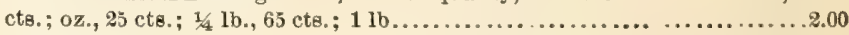
GOLDFN TROPHY - In form and size like the well-known Trophy, but in color a beautiful yellow, sometimes streaked with red. Pkt., 5 cts.;

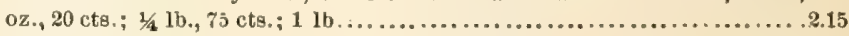

General Grant-A good variety; fruit large and of good quality, and ripens rapidly. Pkt, 5 cts. ; oz., 20 cts.; 1/4 lb., 60 cts. ; 1 lb ........... 1:85 Paragon-Similar to the Acme in all respects, except that the Paragon is of a bright, glossy crimson, entirely free from the purplish tinge. Pkt.

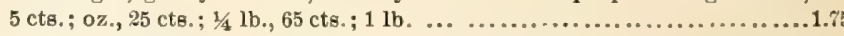

Hubbard's Curled Leaf-The fruit, which grows in clueters, is of a rich, dark red color, and small to medium in size. The plant is dwarf and can be at closer than most varieties. Pkt., 5 cte.; oz, 20 cts.; $1 / 4 / 6$. 16. varien. 200

Canada Victor-One of the earliest; of medium size. Pkt., 5 cts.; oz.,

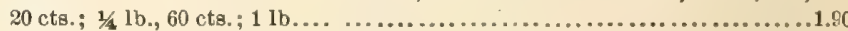
Yellow Plum-A small variety, used principally for pickling. Pkt., 5 cts. ; oz., 25 cts. ; $1 / 4$ lb., 75 cts.; 1 lb.... ............................. 2.50 Red Cherry -A small Cherry-8haped variety used for pickling. Pkt, 5

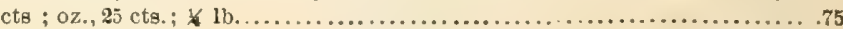

\section{STRAWBERRY, OY WINTER CHERRY.}

Small, yellow aweet fruits, considered by many very fine for preeerves. The plant is as easily grown as a Tomato, and is immensely productive. The fruit is enclosed in $\mathrm{s}$ husk, $\mathrm{s}$ ls shown in the illustration, and may be kept within these husks in excellent condition all winter. Pkt.....

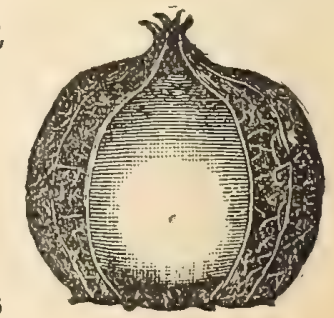

\section{TOBACCO SEED.}

Connecticut SEed Leaf-Pkt., 5 cts ; oz., 25 cts.; $1 / 4$ lb., 75 cts.; 1 lb...2.25 Havana-Pkt, 5 cts.; oz., 25 cts.; $1 / 4$ lb., 75 cts.; 1 lb...................2.25

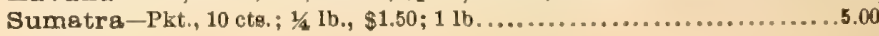




\section{TURNIP.}

German, Steckrübe. French, Navet.

Light, well-manured soil ls best suited for Turnips. Sow the earliest varieties in April, in drills about 15 inches apart, and thin out to 6 to 9 inches in the rows, For a enccession, sow at intervals until the end of August. Turnipe may be preserved nntil spring by cutting off the tops about 1 inch from the bulb and atoring in a ccol, dry shed or cellar, and covering with dry asnd.

If by mail in quantities of $1 / 2 l b$. and upwards, postage must be added at the rate of $8 \mathrm{cts}$. per $\mathrm{lb}$.

1 oz. to 150 feet of drill; 2 lbs. to the acre in drills.

EXTRA EARLY MILAN-This variety comes into use about the same time as the Purple Top Munich, but unlike that sort it retains its sweetness and good eating qualities until late in the season. It is strap-leaved, flat in shape, with a purple top; flesh white and of excellent quality. Pkt., 5 cts.; 0z., 10 cts.; $1 / 4 \mathrm{lb}, 25$ cts.; $1 \mathrm{lb}$...

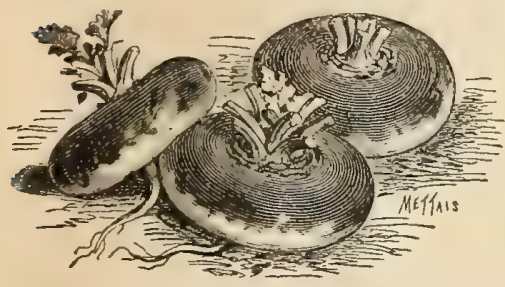

Extre Early Purple-Top Munich-The chief value of this new variety consists in its earliness. It is a very handsome Turn ip, with purplish-red top, flesh as white as snow. Pkt, 5 cts.; oz, 10 cts.; 1/4 lb., 15 cts.; $1 \mathrm{lb}$

PURPLE-TOP MUNICH.

RED TOP STR AP LEAF -A rapid grower; the most popular variety for early use, either for the table or stock. Pkt., 5 cts.; oz., 10 cts. : lb., 15 cts ; $1 \mathrm{lb}$.

EARLY WHITE STRAP LEAF-Differs from the preceding only in color. Pkt., 5 cts.; oz , 10 cts.; $1 / 2$ lb, 15 cts.; $1 \mathrm{lb}$...

EARLY FLAT DUTCH-One of the best varieties for spring sowing. Plt., 5 cts.; oz., 10 cts.; 1/4 lb., 15 cte.; $1 \mathrm{lb} .$.

EARLY SNOWBALL-Rapid grower; flesh sweet and tender. Pkt., 5 cts.; oz., $10 \mathrm{cts}$; 1/2 1b., 20 cts.; $1 \mathrm{lb}$.

Jersey Navet-Early, eweet and tender; of superior quality. Pkt , $5 \mathrm{cts.}$ oz., $10 \mathrm{cts}$; b lb., $15 \mathrm{cts}$; $1 \mathrm{lb} . .$.

PURPLE-TOP WHITE GLOBE-A handsome-looking bulb, and is rapidly taking the lead of all other varieties of early Turnips for market garden purposes. Pkt., 5 cts.; oz., $10 \mathrm{cts}$; 1/4 $1 \mathrm{lb} ., 20 \mathrm{cts}$; $1 \mathrm{lb}$

WHITE STONE-Similar to the Yellow Stone, only that the flesh is white, It is one of the very best summer sorts for table use. Pkt., 5 cts.; oz., 10 cts.; $1 / 4 \mathrm{lb}$, $20 \mathrm{cts}$; $1 \mathrm{lb}$...

WHITE EGG-An entirley distinct variety. It belongs to the class of quick growing fall Turnips. Its shape is nearly oval, as its name would indicate; flesh very firm and fine-grained; thin snd perfectly smooth skin; and both flesh and ekin are of enowy whitenese. Pkt., 5 cte, ; oz., $10 \mathrm{cts}$; * lb., 15 cte.; $1 \mathrm{lb}$
YELLOW STONE--Medium size, firm; excellent flavor and good keeper one of the best yellow-flesh varieties for table use; it is equally good for stock. Pkt., 5 cts.; oz., 10 cte.; $1 / 4$ lb., 20 cts.; 1 lb.................... .

YELLOW GLOBE-One of the best varieties for general crop ; keeps well until late in the epring; grows to a large size, and excellent both for stock and table ure. Pkt., 5 cte.; oz., 10 cts.; $1 / 4$ lb., 15 cts.; 1 lb....

POMERANIA WHITE CLOBE-One of the most productive; in rich soil the root will frequently grow to 12 pounde in weight; globe shaped; skin white and smooth. Pkt., 5 cts.; oz., 10 cts.; 1/4 lb., 15 cts.; 1 lb.

LARGE WHITE NORFOLK-A large globe-ehaped variety.! One of the best for stock. Pkt., 5 cts.; oz, 10 cts.; 1 lb., 20 cts.; 1 lb.

Long White or Cow Horn-The roots good; shaped like a Carrot, ubout half of which is formed above the ground; flesh white, fine-grained, and sweet for table use. Pkt., 5 cts.; oz., $10 \mathrm{cts.;1/4} \mathrm{lb.,} 15 \mathrm{cts}$; $1 \mathrm{lb}$.

GOLDEN BALL (ROBERTSON'S)-A rapid grower; globe-ebaped and and of a beautiful bright yellow color, and a good keeper. Pkt, 5 cte.; oz., 10 cts.; 1 lb., 15 cts.; 1 lb.

YELLOW ABERDEEN-Very hardy and productive; very firm; good keeper; color pale yellow, and closely resembles the Rutabagas; good either for table or stock. Pkt., 5 cta, ; oz, 10 cts.; $1 / 2 \mathrm{lb}, 20 \mathrm{cts}, ; 1 \mathrm{lb}, \ldots . . .40$

Teltow, or Small Berlin-A small spindle-shaped sort, used fоr Aavoring soups, Pkt., 5 cts.; oz., 10 cts.; 1/4 lb., 20 cts.; $1 \mathrm{lb..................60}$

Seven Top-The tops are used for greens. Pkt., 5 cts.; oz., 10 cts.; $1 / 41$ lb.,

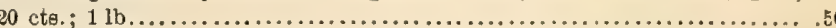

\section{RUTABAGA-Swedish or Russian Turnip.}

In some parts of the country grown exteneively as a farm crop. The roots may be preserved in pit or cellar during the winter, and are excellent for table use. Sow from the 10th of June to the middle of July, in drills two feet apart, and thin out to eight inches.

CURRIE'S IMPROVED PURPLE TOP-A most excellent sort for either table or stock; yielda heavily without tendency to long neck. Pkt., 5 cts.; oz., 10 cts.; 3 lb., $20 \mathrm{cts}$; $1 \mathrm{lb}$

Skirving's Purple Top-A good variety for table or stock; grows to a large size; flesh firm, solid and aweet, and a good keeper. Pkt., 5 cts.; oz., $10 \mathrm{cts}$; $1 / 1 / 4 \mathrm{lb} ., 15 \mathrm{cts} . ; 1 \mathrm{lb}$

LANG'S IMPROVED-An early variety; bulb handeome and of fine quality. Pkt., 5 cts.; oz., 10 cts. ; 1/4 lb., 15 cts.; 1 lb..................... .

Imperial (Purple Top)-Very hardy and productive; flesh jellow, solid, sweet and fine flavored; equally good for stock or table use. Pkt, 5 cts.; oz., $19 \mathrm{cts}$; $1 / 4 \mathrm{lb} ., 15 \mathrm{cts} . ; 1 \mathrm{lb}$

SHAMROCK-A very fine purple-top variety bulb; large and handsome, with small top and few leaves; a good keeper. Pkt., 5 ets.; oz., 10 cts.; $1 / 1 \mathrm{lo}, 20 \mathrm{cts}$; $1 \mathrm{lb}$.

LARGE WHITE, or SWEET GERMAN-An excellent variety; flesh white, firm and solid; grows to a large size and has a very rich flavor. Pkt., 5 cts.; oz., 10 cts.; $1 / 4$ lb., $20 \mathrm{cts} ; 1 \mathrm{lb}$............................ .40 For large quantities, write for special prices. See Farm Seeds, page 26

\section{SWEET, POT AND MEDICINAL HERBS.}

No garden is complete without a few herbs for culinary or medicinal purposes. Harvest them carefully on a dry day, before they come in to full bloom.

Anise (Pimpinella Anisum)-Cultivàted principally for garnishing. Pkt, 5c.;

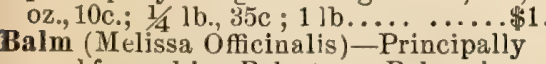
used for making Balm tea or Balm wine. Pkt., 5c.; oz., 25c.; 1/4 lb.. 85c.; 1 lb...3. Basil, Sweet (Ocymum Basilicum) - The leaves and tops of the shoots are used for soups, stews and sauces. Pkt., 5c.; oz., $20 \mathrm{cts}$; $1 / 4 \mathrm{lb}$., $60 \mathrm{c}$; $1 \mathrm{lb} . . . .$. ...2.2.

Bene (Sesamum Orientale)-Pkt., 5c; oz., 15c.; $1 / 4 \mathrm{lb}, 50 \mathrm{c} ; 1 \mathrm{lb} . \ldots \ldots \ldots \ldots . .1 .75$

Borage (Borage Officinalis)-Excellent for bees. Pkt., 5c ; 0z., 15c.; $1 / 4 \mathrm{lb}$. 50c.; $1 \mathrm{lb}$................................ vated for the seed, which is used in confectionery and medicine. Pkt., 5c.; oz., 10c.; $1 / 4$ lb., $25 \mathrm{c} . ; 1$ lb.............

Catnip (Nepeta Cataria)-Pkt., 5c.; oz., $40 \mathrm{c}$; $1 / 4 \mathrm{lb},, \$ 1.25$; $1 \mathrm{lb} . . . \ldots \ldots \ldots \ldots . . . . .4$ Coriander(Coriandrum Sativum)-_........ are used by confectioners. Pkt., 5c.;

Dill (Anethum Graveolens)-The leaves are used in soups and sauces, and put along with pickles. Pkt., 5c.; oz., 10c.;

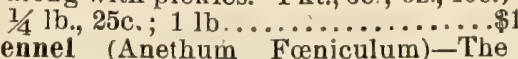
leaves, boiled, used in many fish sauces. Pkt., 5c.; oz., 10c ; $1 / 4$ lb., 25c.; $1 \mathrm{lb} . . . .1$
orehound (Marrubium Vulgare)-Principally used for medicinal purposes. Pkt, 5c.; oz., 30c.; 1/4 lb., $\$ 1.00 ; 1$ lb. 3.00 Hyssop (Hyssopus Officinalis) - The leafy tops and flowers are gathered and dried for making Hyssop tea. Pkt., 5c.; oz., 25c.; 1/4 lb., 75c.; $1 \mathrm{lb}$......2.2.50

Lavender (Lavendula Spica)-A popular aromatic herb. Pkt., 5c.; oz., 20c.;

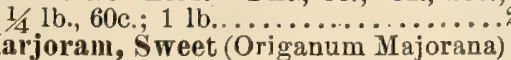
-For seasoning. Pkt., 5c.; oz.. 20c.;

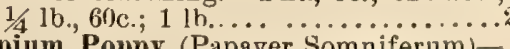

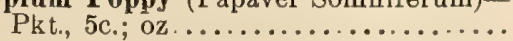
Pennyroyal(Mentha Puleguim) - A well known aromatic herb, also useful as a foliage plant. Pkt..

75 Rosemary (Rosmarinus Officinalis)-An aromatic herb. Pkt., 5c.; oz., 30c.; $\$ 1 / 4$ lb., $\$ 1.00 ; 1 \mathrm{lb} . . . . . \ldots . . . . . . . . . .3 .00$
Rue (Ruta Graveolens)-Used for medicinal purposes; also given to fowls for the roup. Pkt., 5c.; Oz., 15c.; $1 / 4 \mathrm{lb}$., $40 \mathrm{c} . ; 1 \mathrm{lb} . \ldots \ldots \ldots \ldots \ldots \ldots \ldots \ldots \ldots .11 .50$

Saffron (Carthamus Tinctorius) - Pkt., 5c.; oz., 15c.; $1 / 4$ lb., 40c.; 1 lb.........1.50

Sage (SaIvia Officinalis)-The leaves and tender tops are used in stuffing and sauces. Pkt., 5c.; oz , 15c.; $1 / 4$ lb., 40c.;

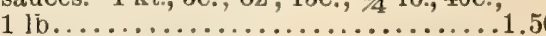

Savory, Summer (Satureia Hortensis)Used for seasoning. Pkt., 5c.; oz., 15c.; $1 / 4$ lb., 40c.; 1 lb..................1.50

Tausy (Tanacetum Vulgare)-Pkt., 5c.; oz., 30c.; 1/4 lb., $\$ 1.00$ : 1 1b...........3.50 Thyme, Broad Leaved (Thymus Vul garis)--For seasoning, etc. Pkt., 5c.; oz., 30c.; $1 / 4$ lb., \$1.00; 1 lb..........3.00

Tarragon (Artemesia Dracunculus)Used in salads, soups, etc. Pkt., 25c.; oz............................5.00

Wormwood (Artemesia Absinthium)Used for medicinal purposes; it is beneficial to poultry and should be planted in poultry grounds. Pkt., 5.c.; oz., 25c.; $1 / 4$ lb., $\$ 1.00 ; 1$ lb................. 3.00

\section{.}

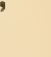




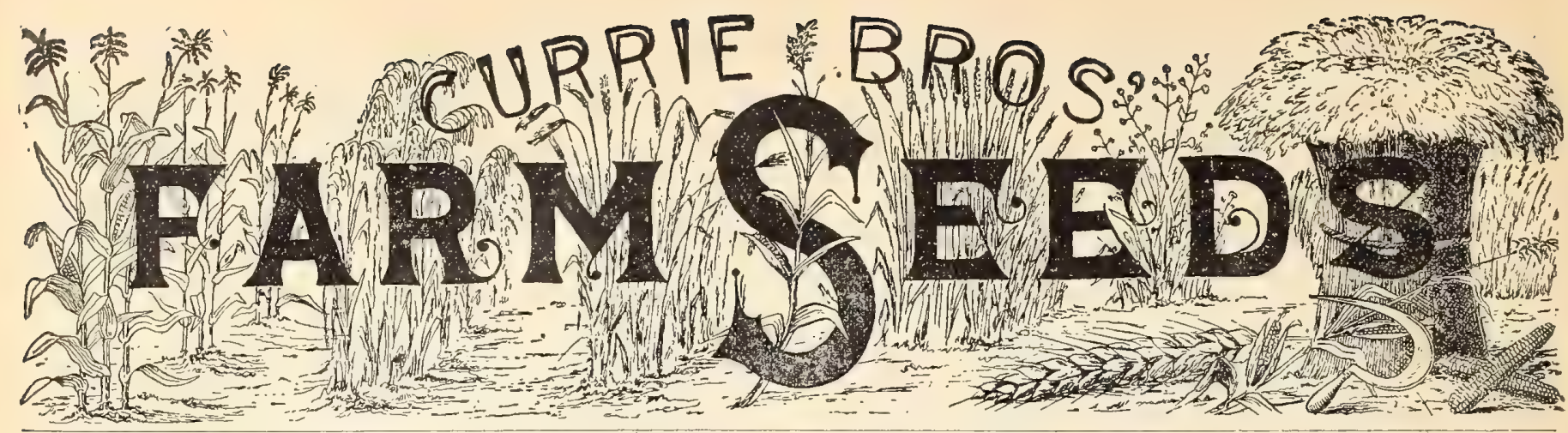

If by mail in quantities of $1 / 216$. and upwards, add 8 cts. per $1 b$. and 15 cts. per quart extra.

\section{MANGEL WURZEL and SUGAR BEET.}

Long Red Mangel Wurz - A popular fleld variety, largely grown for feeding stock. The roots are usually very large and of excellent quality. Pkt., 5 cts.; oz., 10 cts.; $1 / 4$ lb., 15 cts.; 1 lb., 39 cts.; $10 \mathrm{lbs}$. $\$ 2.50$

GOLDEN TANKARD-A good cropper, of fine form and excellent flavor. Color, bright yellow. Pkt., 5 cts; oz., $10 \mathrm{cts} . ; 1 / 4 \mathrm{lb} ., 15 \mathrm{cts} . ; 1 \mathrm{lb} ., 3 i \mathrm{cts} . ; 10 \mathrm{lbs}$................. 3.00 Kinver Yellow Globe-A favorite variety. Pkt,, 5 cts.; oz., 10 cts.; $1 / 4$ lb., 15 cts.; 1 lb., 30 cts.; 10 lbs.............2.50 OURRIE'S IMPROVED MAMMOTH LONG RED MANGEL WURZEL-An exceptionally large growing variety and of finest quality. Specimens of this sort often weigh from 25 to $30 \mathrm{lbs}$. Pkt., 5 cts.; oz., $10 \mathrm{cts}$; $1 / 4 \mathrm{lb}$., 15 cts.; 1 lb., 35 cts.; $10 \mathrm{lbs}$

Norbiton's Glant Long Red Mangel Wurzel-A fa. vorite Long Red variety. Pkt., 5 cts. ; oz., 10 cts.; $1 / 4$ 1b., 15 cte.; 1 lb., 30 cts.; $101 \mathrm{lbs}$.

Elvethan Long Yellow Mangel Wurzel-Similar to the Long Red, color excepted; very deeirable. Pkt., 5 cte.; oz., 10 cts.; 1/4 lb., 20 cts.; 1 lb., 35 cte.; 10 lbs.
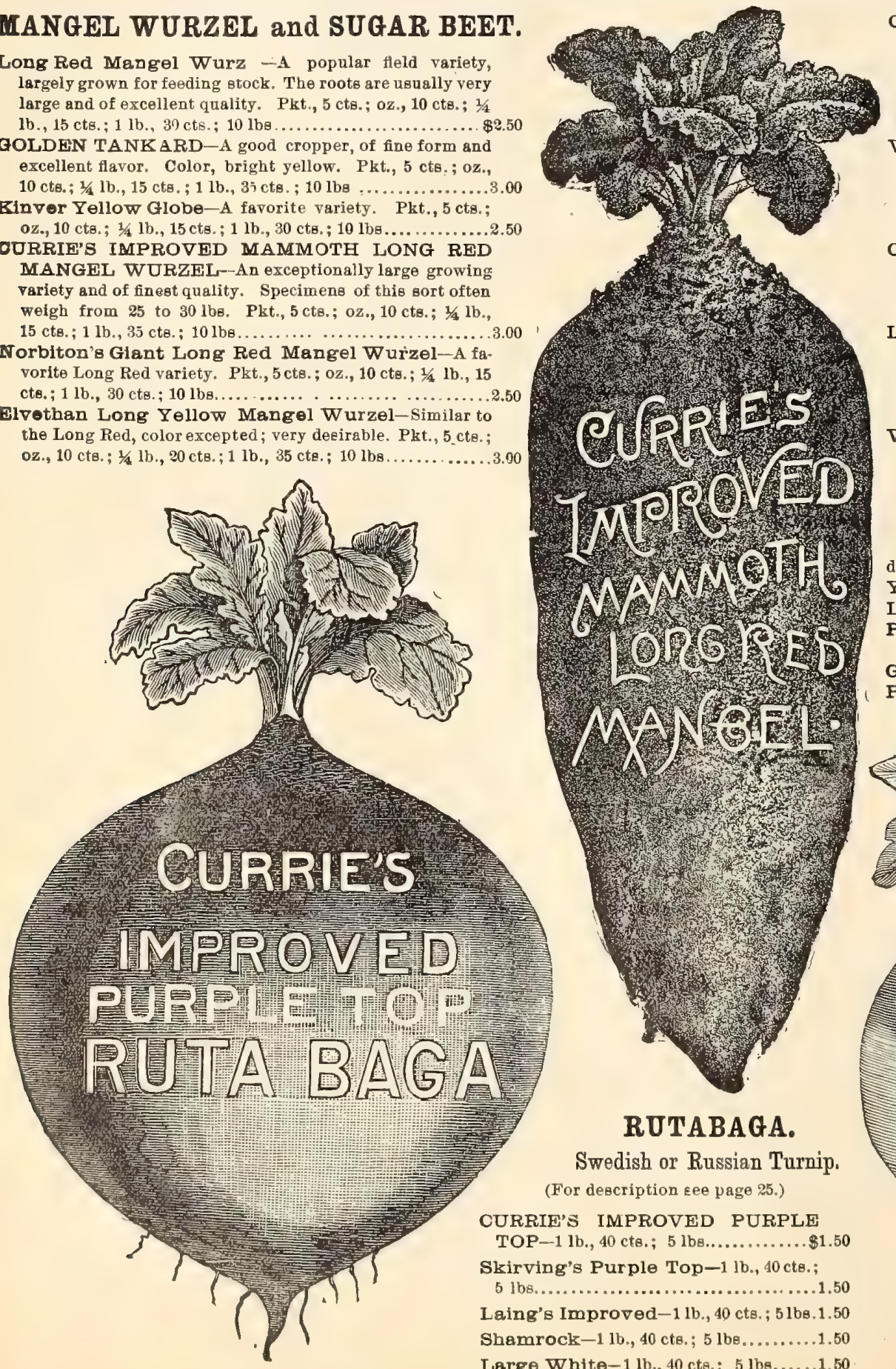

Carter's Warden Prize Yellow Globe Mangel Wurzel-This variety is admirably adapted for shallow soil, although its roots attain to a very great eize, weighing from 15 to 18 pounds. It is excellent in quality. Pkt, 5 cte. oz., 10 cts.; 1/4 lb., 15 cts.; 1 Ib., 40 cts.; 10 lbs. $\$ 3.00$ White Sugar Beet-The variety so extensively grown in France for the production of 8 gigr. A large grower, excellent for feeding stock. Pkt., 5 cts.; oz., 10 cts.; 1/4 1b., 15 cte.; 1 lb., 30

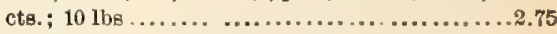
Carter's Sugar Cane Beet-A pariety ex ceedingly rich in saccharine matter. Highly prized. Pkt., 5 cts.; 0z., 10 cts.; 1/4 1b., 15 cts.;

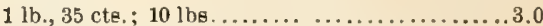

LANE'S IMPERIAL SUGAR BEET-A great improvement on the common sugar beet containing a very large percentage of sugar Pkt., 5 cte.; oz., 10 cte.; 1/4 lb., 15 cte.; 1 lb., 30 . cts.; $10 \mathrm{lbs}$..

3.00

(2) 47,20130

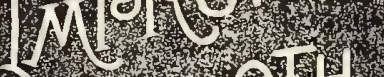
A. M n 1.1. 1.615

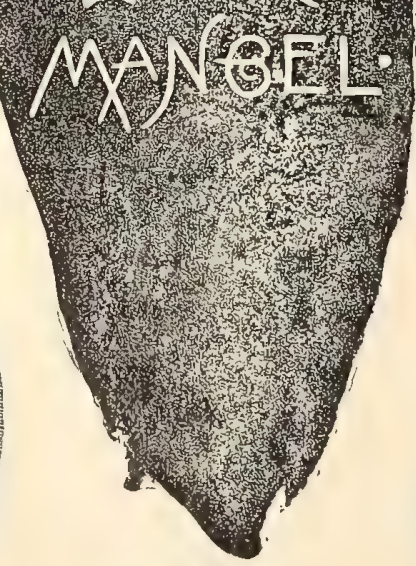

RUTABAGA.

Swedish or Russian Turnip. (For description tee page 25. .)

CURRIE'S IMPROVED PURPLE TOP-1 lb., 40 cts. ; 5 lbs............. \$1.50 Skirving's Purple Top-1 lb., 40 cts.

5 lbs................................50 Laing's Improved-1 1b., 40 cts. ; 5 lbs.1.50 Shamrock-1 1b., 40 cts.; $51 \mathrm{bs.........1.50}$ Lerge White-1 lb., 40 cte.; 5 lbs......1.50
VILMORIN'S SUGAR BEFT-A most excellent variety. Pkt., 5 cte. ; oz., 10 cts.; $1 / 4 \mathrm{lb}$. 20 cts.; $1 \mathrm{lb}$.

\section{TURNIPS.}

Large growing varieties for feeding stock. (For descriptions see page 25 .

Yellow Aberdeen-1 lb.,"40 cts ; 5 lbs.........1.50 Large White Norfolk-1 lb., $40 \mathrm{cts}$.; 5 lbs,...1.50 Pomeranian White Globe-1 lb., $40 \mathrm{cts}$; 8

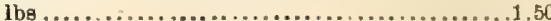
Golden Ball-1 lb., 40 cte. ; 5 lbs... ........... 1.50 Purple Top White Globe-1 1b., 40 cts.; 5 lbs.1.50

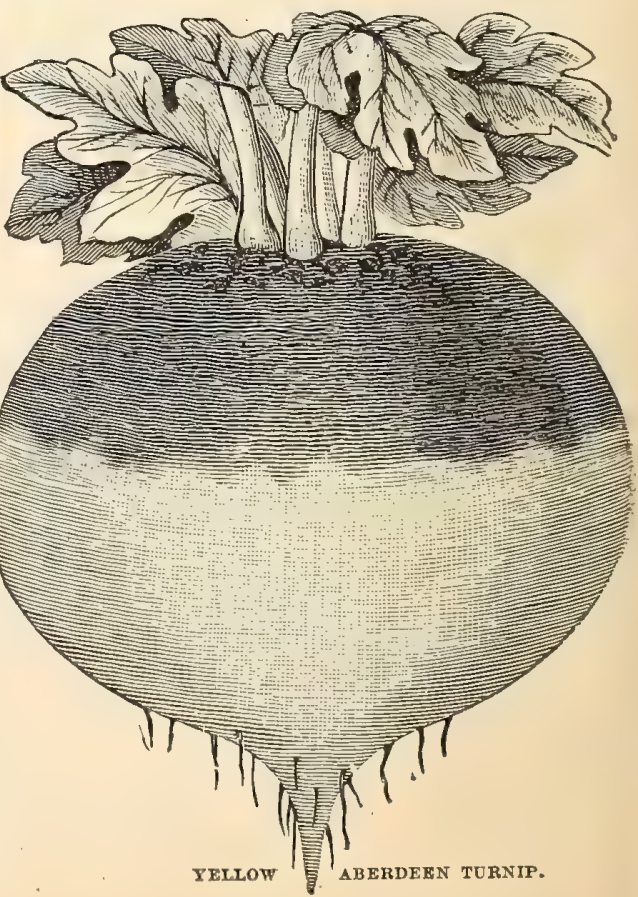




\section{FODDER PUANTS.}

All the varieties offered on this page are esteemed as forage plants, and we would especially direct attention to the Red Cob Fodder Corn than which no more valuable crop can be grown on the dairy and stock farm. Our largest dairymen use it and depend upon it for their winter supply more than any other crop on the farm.

\section{ENGLISH RAPE.}

Recent trials at the Wisconsin Agricultural Experiment Station have demonstrated that this is a valuabie crop for sheep raisers. Sow broadcast, using

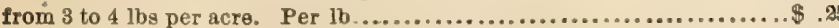

\section{MILLETS.}

(Subject to market fluctuation.)

COMMON MILLET (Panicum Miliaceum)-Very early; grows 2 to 3 feet high; foliage broad. (50 pounds to the bushel.) Quart, $15 \mathrm{cts}$; bushel........ 1.00 GEBMAN, OR GOLDEN MILLET-Medium early; grows 3 to 5 feet high; hesds closely condensed; spikes very numerous; seeds round, golden yellow, in rough sheaths. (50 pounds to the bushel.) Quart, $15 \mathrm{cts}$.; bushel...1.25

\section{HUNGARIAN (GRASS) MILLET.}

\section{(Panicum Germanicam.}

Early; grows 2 to 3 feet high; abundant foliage and slender head; withutands drought, and yields well on light soil. ( 48 pounds to the bushel.) Quart, 15 cts.; bushel.

\section{JOHNSON GRASS.}

\section{(Sorghum Halapense.)}

A perennial grass with cane-like roots. It is very tender and nutritious; good for stock; should be cut for hay when it comes into bloom: (25 pounds to the bushel). Per lb., 25 cts.; bushel..

\section{WHITE BRANCHING DOURA.}

For feeding stock few plants are equal to this one. It produces stalks in great abudance, with an enormous quantity of foliage very rich in saccharine matter. It also bears large quantities of seeds, which, when ground, make excellent feed. Plant the seeds in rows 4 feet apart, dropping three or four seeds every 18 inches. Thin to two plants when strong

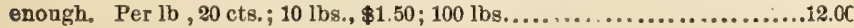

\section{YELLOW BRANCHING DOURA:}

A strong, tall-growing sort, attaining a height of from 9 to 12 feet. It produces great quantities of seed, which is golden-yellow in color. Like the White Millo its stalks and leaves are also very valuable for feed. Per lb., 20 cts.; $10 \mathrm{lbs}, 81.50 ; 100 \mathrm{lbs}$. .12 .00

\section{TEOSINTE.}

(Reana Luxurians.)

A very valuable fodder plant resembling Corn, bat grows more compact, with larger and broader leaves. If allowed to grow it will often attain a height of 15 feet; but it may be cut three or four times durıng the season. The stalks are particularly rich in saccharine matter, therefore very nutritious. Sow at Corn planting time in drills 3 feet apart, dropping two or three seeds in every foot. Pkt., $10 \mathrm{cts}$; $0 z ., 20 \mathrm{cts}$. ; $1 / 4 \mathrm{lb}$., $50 \mathrm{cts}$; $1 \mathrm{lb.....1.75}$

\section{WILD RICE.}

(Zizania Aquatica.)

For low, swampy lands few forage plants are so valuable as this one. It is excellent feed either green or dry for cattle, and is eaten greedily by them. Per lb.

\section{VETCHES.}

Excellentfeed for cattle and hogs. A very good substitute for Corn and Peas. Sow broadcast the same as Wheat. For green fodder they are often sown with Oats, and are much relished by stock. Per lb., 10 cts. bushel $(60$ lbs.)........................................... 5.50

\section{LUPINE.}

Besides being an excellent forage plant very much relished by cattle, the Lupine is valuable for enriching poor, sandy soil, and is extensively used for that purpose in Europe. Per lb., $15 \mathrm{cts}$; $10 \mathrm{lbs}$., $\$ 1.00 ; 100 \mathrm{lbs......8.00}$

\section{KAFFIR CORN.}

A variety of Sorghnm cultivated for both forage and grain. Per 1b., 15 cts. ?

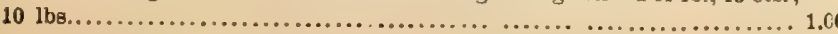
1.25

\section{RED COB FODDER CORN.}

This variety is now! grown in the large? dairy regions of Wisconsin so im. mensely as almost to exclude all of the other so-called Fodder Corns, and the verdict is that it is the best. It is sweet, tender and juicy; has short joints, abundance of leaves, and grows to a great height, furnishing more than double the bulk and much more nourishment than any ordinary field Corn. The question has frequently been put at large gatherings of men interested in the growing of forags crops: "What [Corn is the best for Fodder and Ensilage Pur. poses?" and the universal/opinion has always been rendered in favor of the Red Cob. Every lot is tested and recleaned, hence you buy no cobs or dirt

Peck, 50 cts. ; bushel .........................................\$1 2

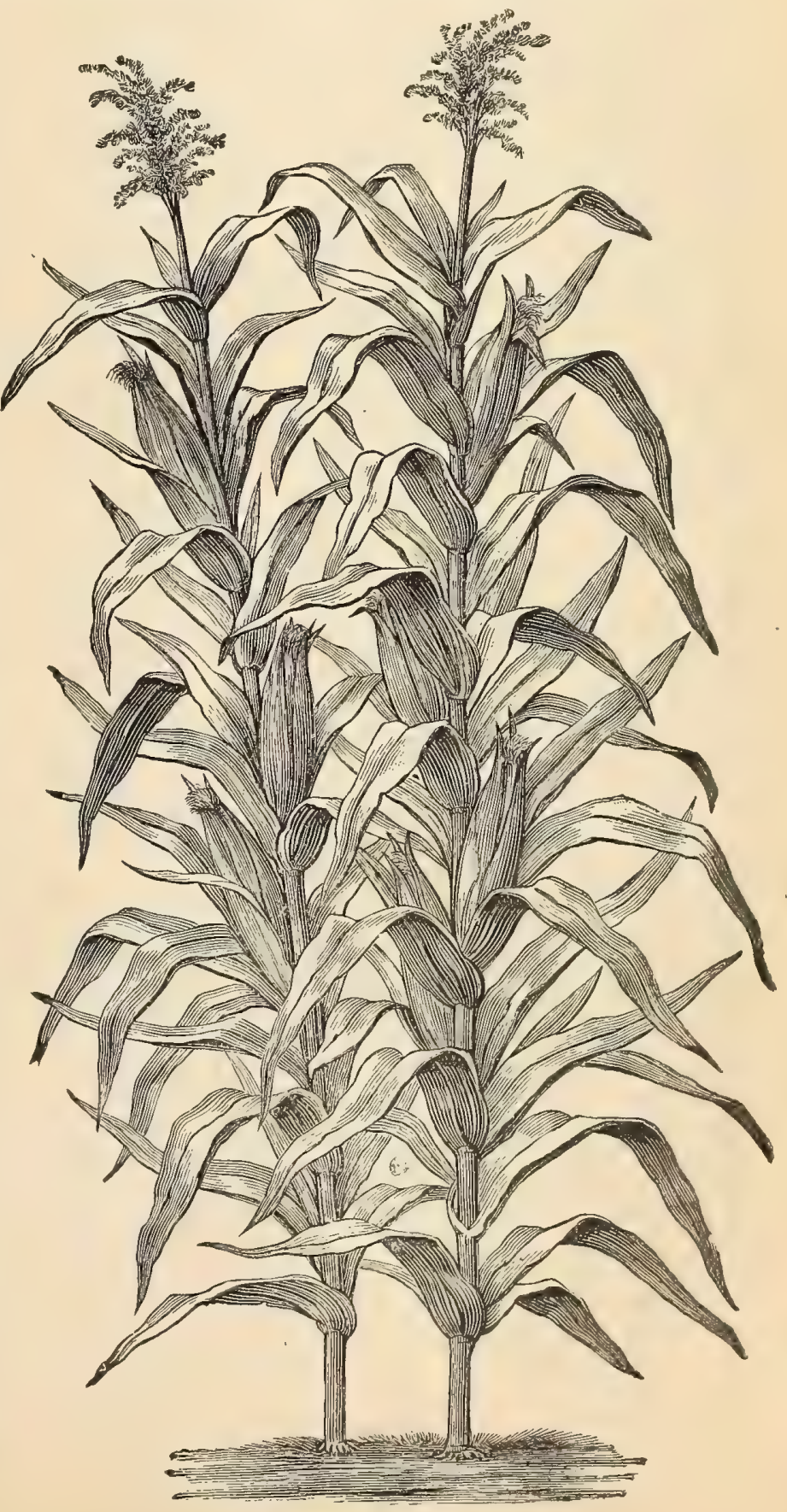

RED COB, FODLER CI RN 


\section{CORN.}

If by mail add 15 cts. per quart for postage.

King of the Earlies-The Errliest Dent Corn grown.

This Corn originsted with the originator of the Pride of the North, Corn and Is the earliest of all Dent Corn. The originator describes it as follows:

"This is without doubt the earliest and finest Dent Corn in cultivation-bright orange color. Short, leafy stocks, medium-sized ears, small red cobs; long, deep grains, very rich in oil and starch-the most prolific Corn extant. This Corn is evidently adapted for planting in high latitudes, and will mature a crop farther north than any other known variety, and for threshing there is no other Corn that will compare with it, will shell easier, will make better fodder, can be threshed earlfer than any other known variety. It ripens earlier, dries out

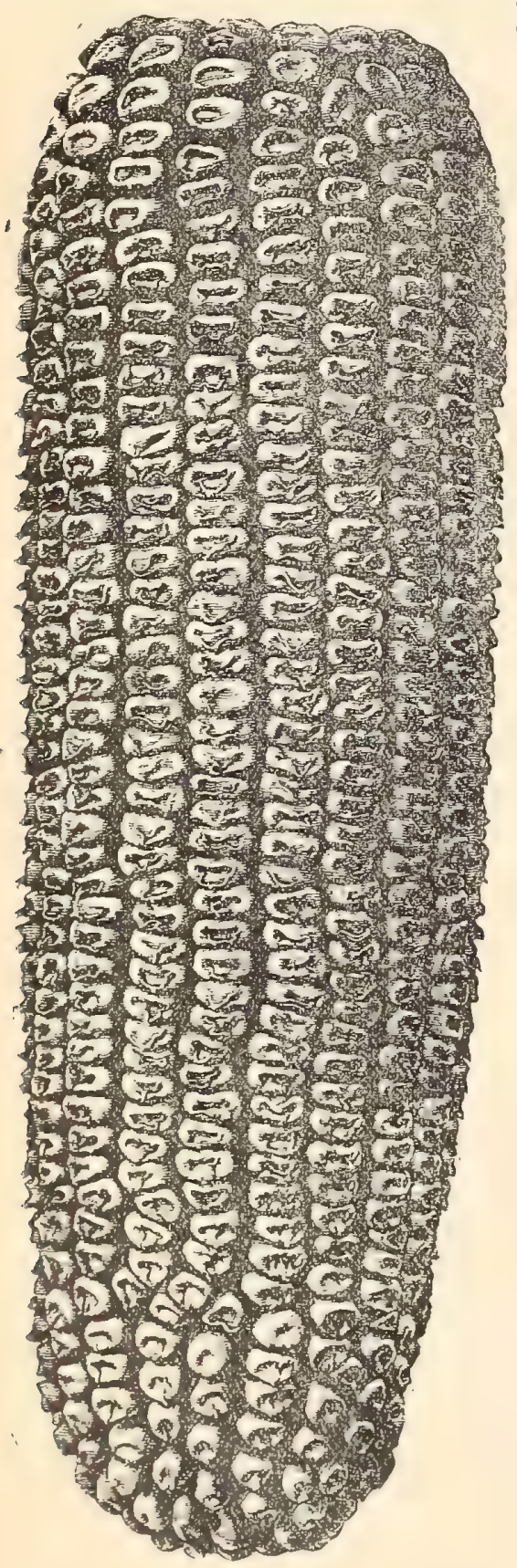
quicker, makes better fodder, stands the drought better and will yield more No. 1 shelled Corn than sny other known variety.

Quart, 20 cts.; peck,

65 ct8.; bushel......\$2,00

Pride of the North -A famous early variety of Yellow Dent. It will shell 60 to 64 1be. per bushel of 70 1be. of ears 14 to 16 rows often placed irregularly on the small red cob. Quart, 15 cts.; peck, 50 cts.; bushel................1.7

Early Butler Dent -A handsome Yellow Dent Corn, producing large - eized ears and maturing a few days later than King of the Earlies. Quart, 20 cts.; peck. 65 ct..; bushel.......2.00

Early Mastodon The largest of all the Yellow Dent varieties. It is a strong and rank grower, and matures in abont 100 daye. Quart, 20 cts. : peck, 65 cts.; bushel.2.00

Early Wisconsin White Dent-This is the best white Dent Corn that can be grown in this northern latitude, never failing to ripen before frost comes, and is a most desirable sort further south. It is 16 to $20 \mathrm{row}$, ker nels large, cob small and mostly white.

Quart, 15 cts.; peck, 60 ctø.; bushel .......2.00

Improved Le aming - Ear large, grain deep orange color; emall red cob. Will stand drought remarkably well. We do not recommend it north of latitude $43^{\circ}$ or $44^{\circ}:$ Quart, 15 cts.; peck, 50 .cte.; buehel.1.75

KING OF THE EARLIES.

Angel of Midnight (Yellow Flint)-An extra early yellow flint, 8 rowed variety. The ear is perfect in shape; length, 10 to 13 inches. Rows straight and even, and filled from tip to tip. Stalke are of medium eize. Quart, 15 ctz.; peck, 65 cte.; buehel..................................2.00
The Mercer (Yellow Flint)-Is decidedly the earliest Corn for 80 large an ear of any variety now grown. It is very prolific, ears 9 to 10 inches in length and 12 to 14 rows, well filled out to the tips, and of a golden-yellow color. The Corn matured last year in seventy-five days. Many of the stalks have two, and some three, good eara. Qnert, 15 cts.; peck, 60 cts.; bushel ................................................\$2.00

Champion White Pearl-Very productive; is a strong grower, with ears set Iow. Quart, 15 cts.; peck, 60 cts.; bushel.......................2.00

Wisconsin White Flint-An excellent variety of good eize; grain a dusky white color. Quart, 15 cts. : peck, 60 cts.; bushel.....................2.00

Longfellow Flint-A yellow variety of very handsome appearance; very superior and desirable. Quart, 15 cts.; peck, 60 cts.; bushel............2.00

Self-Husking-The farmer will hail with delight the introduction of this wonderful Corn. As the name implies, it possesses the very peculiar feature of opening its husks and completely stripping its ears, so that the farmer is saved the trouble of husking. It is moreover, a very prolific variety, often producing three ears on a stalk. These are large and handsome, from 10 to 12 inches in length. The cob is emall and the grain is of a beautiful amber color. It is the earliest field Corn in cultivation, a flint variety, and without doubt destined to become the leading field sort. Quart, 15 cts.; peck, 75 cts.; bushel.............................2.50

Brazilian Flour-A variety introduced from Brazil, and very extensively used there as an article of food. The green ears are as sweet as any Sweet Corn, and the ripened grain makes a beantifully white flour, fully equal to that of wheat. The yield per acre is enormous. The stalks are large, and very numerous and make excellent fodder. Quart, $20 \mathrm{cts.}$ : peck, 80 cts.; bushel....

For other varieties quotations will be given on application.

Write for special prices on large quantities.

\section{BEANS-Field Varieties.}

Prolific Tree Bean-A most prolific variety for field culture, producing under ordinary culture from 60 to 80 buehels to the acre. Pint., 15 cte.; quart, 25 cts. ; peck, $\$ 1 . r \theta ;$ bushel................................50 White Marrowfat-Not specially good as a String Bean, but very popular shelled, green or dry. Pint, 10 cts.; quart, 20 cts. ; peck, $\$ 1.00$; buehel.3.50

Canadian Wonder-A verg prolific variety with large pods. Pint, 15 ts.; quart, 25 cts.; peck, $\$ 1.25$; buthel...........................4.50

Large White Kidney-Largely used as a Shell Bean, and equally good as a Snap Bean. Pint., 10 ets.; quart, $20 \mathrm{cts}$.; peck, $\$ 1.00$; bushel.........4.00

Burlingame Medium-Early, hardy and very productive. Pint, 15 cts.; quart, 25 ct8.; peck, $\$ 1.00 ;$ bushel............................. 3.50

Boston Small Pea Bean-This variety is very early, hardy and very prolific. The vine is a rank grower, with a profuse foliage, and the pods grow mainly in clusters of four. One plant of this variety (not specially selected) produced 123 good pods. the pode averaging 6 Beans each. Pint, 15 cts.; quart, $30 \mathrm{cts.;}$ peck, $\$ 1.35$; busheI.........................4.50

White Wonder-A very early and prolific Besn; grows dwarf and bushy, yielding a large crop of large pods well filled with Beans. Pint, 15 cts.; quart, 30 cte.; peck, $\$ 1.50$; buehel...............................5.00 Snowflake-A wonderfully prolific variety. The Beans are of fair aize and good quality. Pint, 15 cts.; quart, 30 cte ; peck, \$1.50; bushel......5.00 Beans subject to market fluctuation. (See Garden Beane, pages 7 and 8.)

\section{CARROTS.}

Large varieties suitable for stock. (For description see pagee 10 and 11.) Danvers-1 lb., 75 cts.; 5 lbs.....................................2.25 Improved Long Orange-1 1b , $65 \mathrm{cte}$; $5 \mathrm{lbs} \ldots \ldots \ldots \ldots \ldots \ldots \ldots \ldots \ldots . . . . . . . . .2 .75$ White Belgian-1 lb., 60 cts.; 5 lbs,.............................2.50

\section{PUMPKIN.}

(For descriptions see page 20 )

Jumbo-1 $1 \mathrm{~b}, \$ 2.00 ; 5$ lbs.................................... 85 Connecticut Field -1 1b., 40 cts.; 5 lbs............................... 1.50

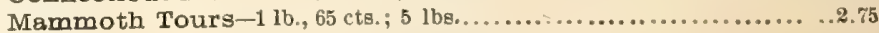
KOHLRABI.

(For descriptions see page 15.)

Large White-1 1b., $\$ 1.50 ; 5 \mathrm{lbs}$ Sow about $4 \mathrm{lbs}$. to the acre.

\section{PEAS-Field Varieties.}

Canadian White-Bushel.........................................1.35 Canadian Blue " Scotch-Bushel . 


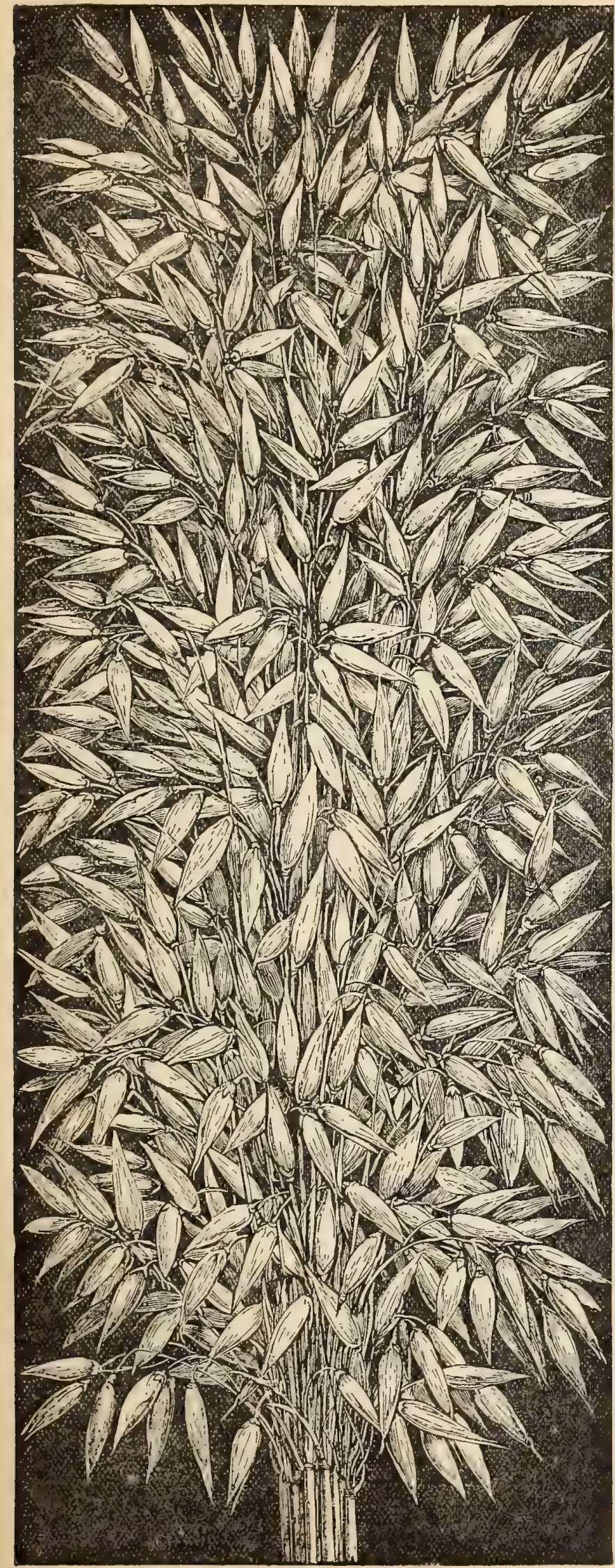

CURRIE'S PRIZE CLUSTER OATS

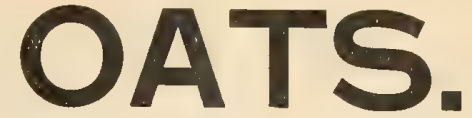

Currie's Prize Cluster-The heaviest and most prolific Oats grown. so universally popular has it become that any description of it or account of its very superior merits would simply be superfluons. We have distributed it everywhere throughout our own and neighboring States, se that it is well known; and we are in no measure surprised to learn from all quarters that it is considered the best Oat in cultivation, by far the earliest and most productive. To substantiate this fact however, we will simply state that Prof. R. P. Speer, Director of the Iowa Agricultural Experimental Station, in his report for 1888, places Prize Cluster at the head of the list of varieties he had teated. Out of fifteen of the leading sorts grown he found by careful measurement: and weight that Prize Cluster produced 69 bushels to the acre, three bushels more than any of the other sorts. For the information of any. one who may not have tried Prize Cluster we will any that it is a white variety of medium growth, very robust, heads very large, and grain remarkably heavy. Peck, 50 cts.; bushel, $\$ 1.25 ; 10$ bushel loț.......... $\$ 11.50$

Badger Queen-One of the earliest. It is a rank grower; otrow stiff; beads long and spreading. Peck, 40 cts. ; bushel, $\$ 1.00 ; 23 / 2$ bushels....2.25 Welcome-A handsome white Oat; large and heavy; a wonderful stooler and very productive. Peck, 40 cts.; bushel, $\$ 1.00 ; 21 / 2$ bushels.........2.25

Improved White Russian-A long grained Oat, possessing many excellent features. Straw stout and free from disease. Peck, 40 cts.;

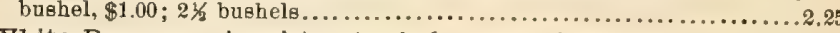
White Bonanza-A variety extensively grown. Peck, 40 cts.; bushel, $\$ 1.00 ; 21 / 2$ bushels.......................................2

White Swede-A variety brought to this country by Swedish emigrants. In appearance it resembles the Russian White. Peck, 40 cts. ; bushel,

$\$ 1.00 ; 21 / 2$ bushels...............................................2.25

Yellow Giant-A strong growing variety. Peck, 40 cts.; buehel, $\$ 1.00$; $21 / 2$ bushels

Black Prolific-A very prolific sort of vigorous growth. Peck, $40 \mathrm{cts}$; bushel, $\$ 1.00 ; 21 / 2$ bushels....................................2.2

\section{WHEAT.}

Saskatchewan Fyfe-This Wheat is heyond question the hardest and best milling Wheat known. Other favorable features are earliness, vigor of growth, productiveness, purity and healthiness. Adapted to all states where Spring Wheat can be grown. Peck, 60 cts,; bushel, $\$ 1.75 ; 21 / 2$ bushels.

\section{RYE.}

Spring-Peck, 50 cts. : bushel, $\$ 1.75 ; 21 / 2$ bushels...................4.00 Winter--Peck, 50 cts.; bushel, $\$ 1.75 ; 21 / 2$ bushels.....................4.00

\section{BARLEY.}

Manshury-The most popular rariety of Barley grown. It is a 6-rowed sort, long heads well flled, straw strong, is later than the common 6rowed and a very heavy yielder. Peck, 50 cte. ; bushel, $\$ 1.50 ; 2 \frac{1}{2}$ bushels.3.50 Two-Rowed-The variety usually grown in Wisconsin and by some considered equal to any. Peck, 50 cts.; bushel, $\$ 1.50 ; 21 / 2$ bushels........... 50 Hulless-A prollfic 2-rowed Barley, the grain having the appearance of Wheat, but larger. Quart, $15 \mathrm{cta}$.; peck, 65 cte.; bushel..................

\section{BUCKWHEAT.}

SILVER HULL-This variety, sown at the same time as the common Buckwheat, continues in bloom longer, matures a few days sooner, and yields nearly double under the same conditions. The flour is whiter and more nutritious Peck, 40 cts. ; bushel, $81.35 ; 21 / 2$ bushels.............. 3.25 JAPANESE-An early and very prolific variety with kernels about double the size of ordinary sorts. It ripens a week earlier than the Silver Hull and yields at least twice as much. Price by mall, 25 cts.; by freight or express, 20 cts. a pound. Peck, 50 cts.; bushel, $\$ 1.50$;

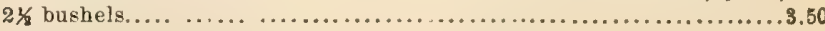
COMMON-Peck, ${ }^{3} 35$ cts.; bushel..................................1.00

\section{SUNFLOWER.}

(See page 28.)

\section{FLAX.}




\section{SUGAR CANE.}

GARLY AM BER-A variety which has been largely tested throughout the conntry with very general success. Its distinctive features are said to be its earliness and great yield of both sugar and sirup. Quart, $15 \mathrm{cts}$.; peck, 65 cts.; bushel. Subject to market fluctuations.

\section{BROOM CORN.}

IMPROVED EVERGREEN-Now grown more extensively than any other variety on account of its color and quality of its brush. Grows 7 feet bigh. Quart, 15 cts.; bnshel.......................................8.50

\section{POPPY.}

OPIUM-Sow in spring, in drills or broadcast. Oz., 20 cts.; lb.........2.00

\section{BIRO SEEOS.}

Prices subject to variation. If by mail in $1 / 2 \mathrm{lb}$. quantities and over, add 8 cents per $1 \mathrm{~b}$. for postage.

Canary. Per 1 b.................15 Rape. Per $1 b \ldots \ldots \ldots \ldots \ldots \ldots \ldots \ldots . \ldots \ldots$ Russian Sunflower. Per $1 b$

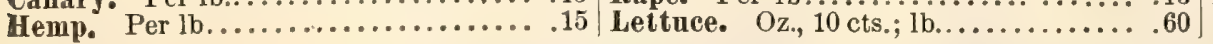

\section{TREE SEROE.}

\section{DECIDUOUS TREES.}

Ash, white (Fraxinus Americana)-Pkt., 5c.; oz., 10c; lb..................... Americana)-Pkt, 10c; oz, 20c.; 1b.\$1 Beech, American (Fagus ferruginea)Pkt., 10c.; oz., 15c.; lb...............

Beech, Purple-leaved (Fagus sylvatica atropurpurea)-Pkt., 10c; oz., 20c ; 1b., 1.75 Chestnut, American Sweet Castane: vesca Ámericana)-Qt., 50c.; peck....3.00 Catalpa Speciosa (hardy)- Pkt., 10c.; oz., $15 \mathrm{c} . ; \mathrm{lb} . \ldots \ldots \ldots \ldots \ldots \ldots . . . . . .1 .00$
Elm, English (Ulmus campestris)-Pkt. $10 \mathrm{c}$; oz. $15 \mathrm{c} . ; \mathrm{lb} . . . \ldots \ldots \ldots \ldots \ldots . \$ 1.25$

80 Elm, American (Ulmus Americana). Pkt., 10c.; oz., 25c.; 1b...............2.00

Larch, European (Larix Europæa)-Pkt. 10c; oz., 15c.; $16 \ldots . . . . . . . . . . . .1 .00$

Maple, Sugar or hard (Acer saccharinum)—Pkt., 20c.; oz., 20c.; 1b.........75 Maple, Norway (Acer platanoides)-Pkt, 10c.; oz., 15c.; lb.................50

\section{EVERGREEN TREES.}

Arbor Viłæ, American (Thuja occidentalis)-Pkt., 10c.; oz., 30c.; lb.......2.75
Arbor Vitæ, Siberian (Thuja Siberica)-

Pkt., 15c.; oz, 40c.; lb............ \$4.00

Cedar, Red (Juniperus Virginiana) -

Pkt., 10c.; oz., 15c.; lb..............60 Hemlock (Ábies Canadensis)-Pkt., 15c.;

oz, 40c.; lb..................4.00 Pine, White (Pinus strobus)-Pkt., $10 \mathrm{c}$; oz., 20c.; lb.....................1.50 Pine, Austrian (Pinus Austriaca)-Pkt.,

10c.; oz., 15c.; lb..................75 Pine Scotch (Pinus Sylvestris-Pkt., 10c.; oz., 25c.; lb...................1.25 Spruce, Norway (Abies excelsa)-Pk̈t, 10c.; oz., 15c.;1b................ .75

\section{CKCTERES.}

The Clovers we offer are all extra choice stock, carefully recleaned.

Prices subject to variation.

If by mail, add $8 \mathrm{cts}$. per pound extra. RED CLOTER, MEDIUM (Trifolium Pratense)

-Sow from 10 to 12 pounds peracre: Per Ib. .15 Bushel at market price.

MayMoth CLOYER (Trifolinm Pratenae Perenne). Sow same as the preceding. Per lb, .15 Bushel at market price.

JAPAN CLOVER (Lespedeza Striata)-A valuable Clover for the South. It flourishes on the poorest soil, and can withstand the most severe drought. Per lb.

ALFALFA, or LUCERNE (Medicago Sativa)Valuable for dry, light soils. Per lb

Bushel at market price.

ITALIAN, or CRIMSON CLOVER (Trifolium incarnatum) $-A$ very valuable pasture Clover, or for fodder when dry. Sow about 15 pounds per acre. Per lb ............

ALSIKE (Trifolium Hybridum)-Stands dry weather well, and does not readily winter kill; much sought after by bees. Per lb., .20 Bushel at market price.

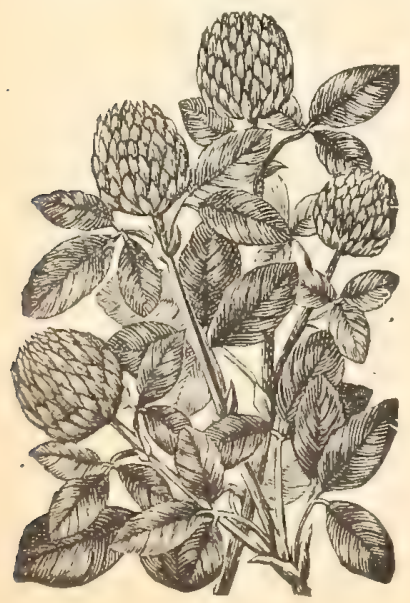

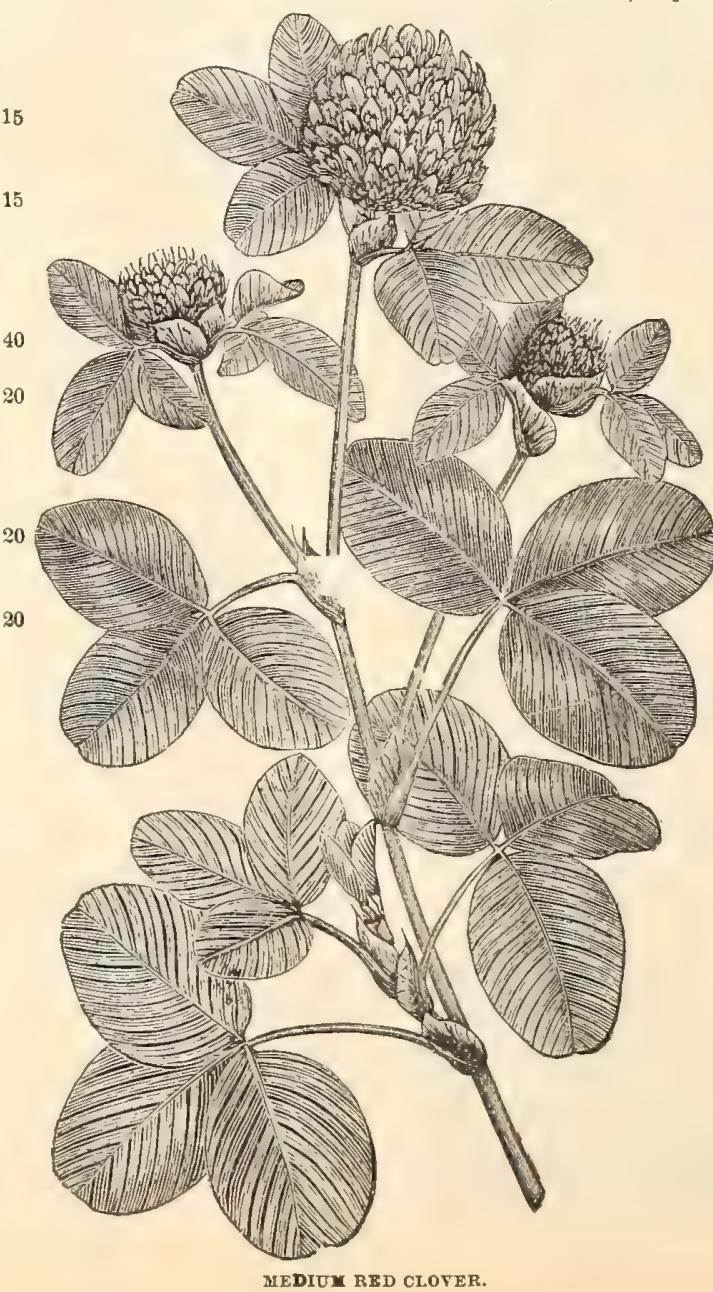

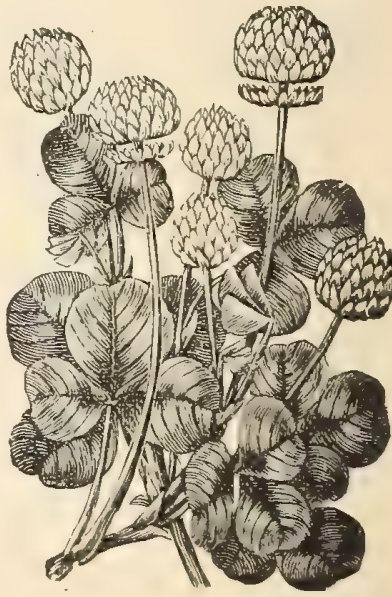

WHITE CLOVER.

WHITE BOKHARA (Melilotus alba)-An erect, branching plant; grows 4 to 8 feet. Flowers small white, in long racemes; very fragrant; excellent bee food. Per lb........ .25 SERRADELLA (Ornithopus Sativus)-This forage plant is especially valuable during the hot, dry months of summer, for while the ordinary pastures may be dry and parched, this plant grows rich and luxuriantly. Sow with any spring grain 6 to 8 lbs. per acre. Per lb., 15 cts; ; 100 lbs........ 4.00 SAINFOIN, ar ESPARSETTE (Onobrychio Sativa)-This valuable forage plant is eapocially valuable for feeding green or dry to milch cows, as it greatly increases the quantity and improves the quality of the milk. A light soil is best adapted for it. Sow from 2 to 3 bushels to the acre. In dry localities it is advisable to sow with some spring grain. Per lb., 15 cts.; 100 lbs......9., 0 WHITE CLOVER (Trifolium Repens)-A valuable addition to mixtures for pasture grass and used in nearly all Lawn mixtures. Per lb. .25 Bushel at market price. 


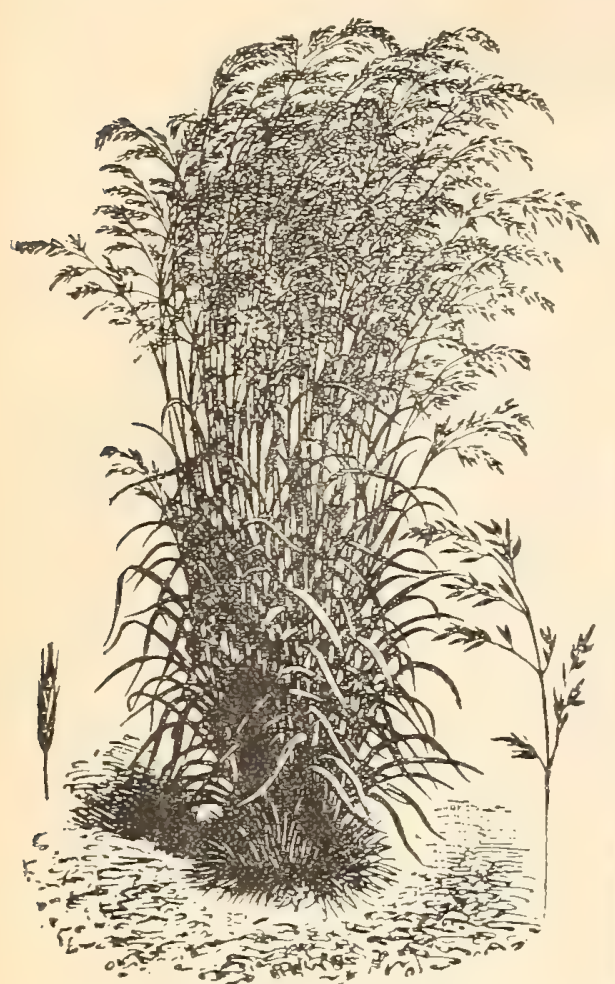

VARIOUS LEAVED FESCLES (Festuca Hetero

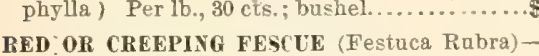

Suitable for sandy and dry soils. (14 lbs. to the
bushel,) Per lb., $25 \mathrm{cts}$; bushel...................60
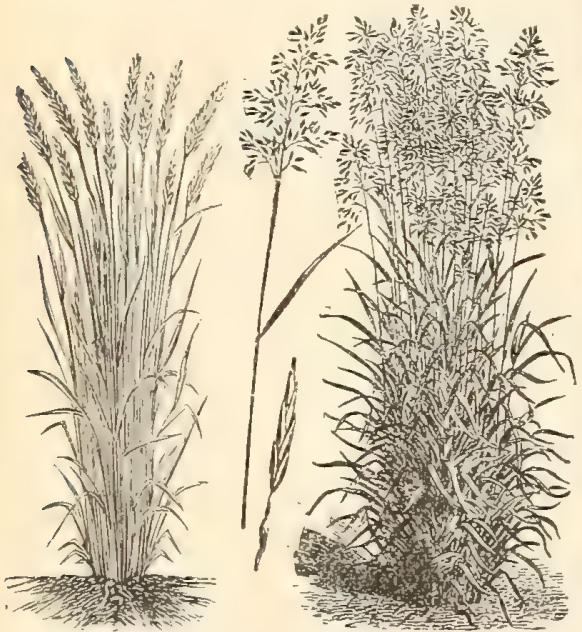

SWEET YERYAL GRADS.

TI TEADOT OA

SWEET VERNAl GRASS, TROE (Anthoxanthum

Odoratum) - A good grass for pasture and lawn

mixtures, making an early growth and emitting

bushels to the acre

Per lb., $50 \mathrm{cts}$; bushel .................4.50

TALL MEADOW OAT) (Avena" Eliator)-A rapid and loxuriant grower, and also a good pasture grass (about 10 pounds to the bushel). Per lb. 15 cts. ; bushel.

FOWL MEADOW (Poa"Serolina)-Makes a rapid grow th. Valuable for low, wet lands (14 pounds

to the bushel). Per lb., 17 cts.; bushel........2.30

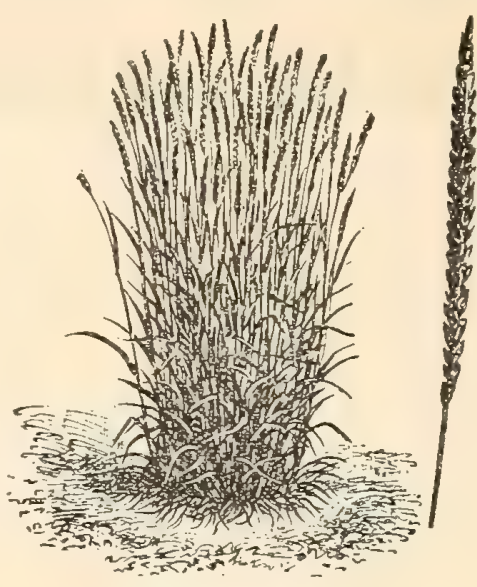

CRESTED DOG'S TAIL (Cynosurus Cristatus)-

Excellent for dry, hard soils. Valuable either

for pasture or lawns (21 pounds to the bushel) Per lb., 30 cts. ; bushel

YELLOW OAT GRASS (Avena Flavescens)-Good for pastare and meadows. (7 lbs. to the bushel)

Per lb., 45 cts.; bushel.......................... 00

WATER MEADOW (Poa Aquatica)-Coarse growing grass suitable for wet soils (14 pounds to the bushel). Per lb., 25 cts.; bushel.

BERMUDA GRASS (Cynodon Dactylon)-An ex-

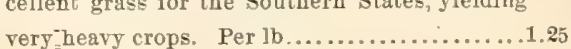

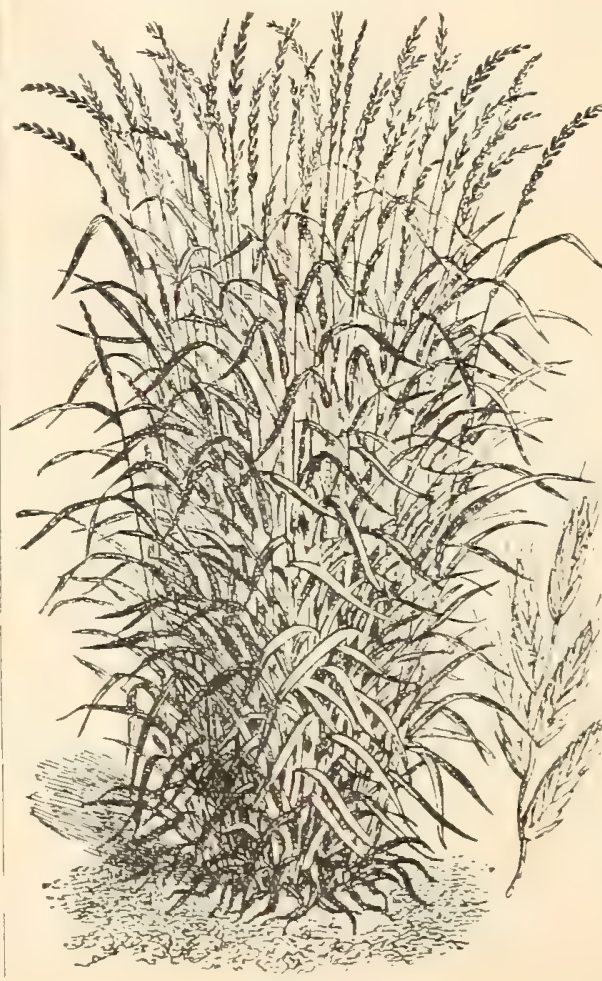

ITALIAN RYE.

ITALIN RYE (Lolium Italicum)-An abundant yielder, good for any soil; one of the best pasture grasses. About 3 bushels to the acre (18 pounds to the bushel) Per lb., 12 cts.; $100 \mathrm{lbs}$

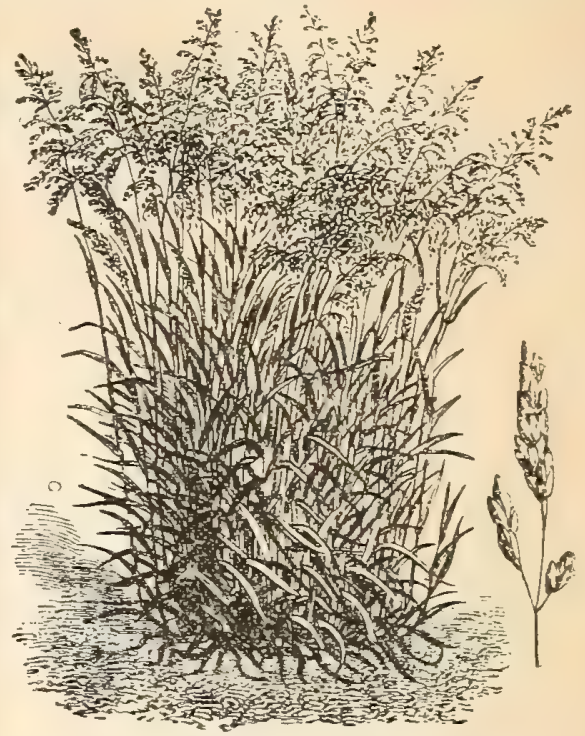

ROUGH STALKED MEADOW GRASS.

ROCGH STALKED MEADOW GRASS (POA Trivialis)-Excellent for damp soils. 11/2 bushels

to the acre (14 pounds to the hashel). Per lb., 25 cts.; bushel........................... $\$ 3.00$ TEXAS BLUE GRASS (Poa Arachnifera)-A valnable grass for the South, withstanding the

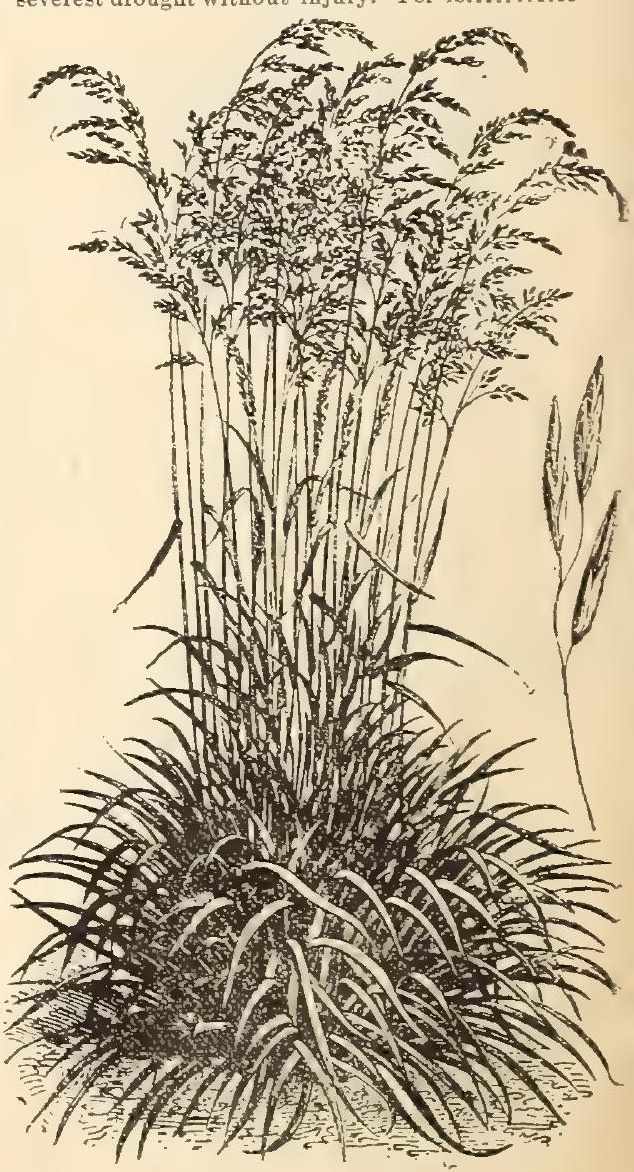

TALL YEADOW FESCUE.

TALL MEADOW FESCUE (Festuca Elatior)Very prodnctive and nutritive; does well in wet and heary soils. (14 lbs. to the bashel). Per

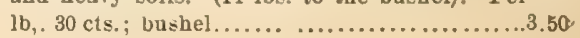




\title{
(urrip Bros.' Hortieultural Guide.
}

\section{CURRIE BROS: \\ SUPERIOR GRASS MIXTURES}

\author{
FOR HAY AND PERMANENT PASTURES,
}

For Either Spring or Fall Sowing.

๑)

OR many years in our western country, Timothy, with more or less Clover mixed in it, has
been, we might say, the only grass farmers have had to rely upon for their hay crops, and
for pasturage. The fact that Timothy cannot be relied upon to make a sure catch, and that it
so soon becomes exhausted ordinarily, has caused farmers no little thought, and naturally set them
to look about for something more reliable and permanent, and at the same time something equally
as nutritious as Timothy. We are to-day in posession of mixtures which, for hay or pasturage, are far superior to anything we have seen.

Experience has taught us, as it has every farmer who has given special attention to the culture of grasses, that while all varieties may do fairly well on any soil, there are certain kinds peculiarly adapted for particular soils. Some succeed admirably on wet, but are of no value on dry, soils, where others are just at home.

In view of these circumstances, we accordingly prepare mixtures of the various kinds and in the proper proportions, especially adapted for the locality and the kind of soil they are to occupy. To have the best results, therefore, farmers in ordering should make it a point to describe the situation of the field, and as near as possible the nature of the soil they wish to seed, and we will then be enabled to send the mixture most suitable. That the farmer may know just what he is buying, we refer him to the special list of Grasses and Clovers illustrated and described in this catalogue. These are what we use in their proper quantities and proportions. We are very particular to have all Grasses true to name and of the very best quality. We will merely add ihat there is now a very great demand for our mixtures, an unmistakable evidence that farmers appreciate them.

We recommend heavy sowing, especially if the soil is poor, so as to make a good sod the first season. Our experience has taught us that from three to four bushels is a fair average, although on very rich soils from two to three bushels will be found sufficient. Where the addition of Clover is desired, a less quantity of the Grass Mixture should be used, in which case we deem it advisable to sow the Grass Mixture and Clovers separately, on account of the difference in the weight of the seeds. In regard to the quantity and varieties wanted for certain soil, if the parties desiring it should write to us, giving a description of the soil and the purpose it is wanted for, we will gladly furnish particulars and prices for the necessary mixture for it.

The usual mixtures consist of the following Grasses: Orchard Crass, Meadow Fox Tail, Sheep Fescue, Hard Fescue, Sweet Vernal, Meadow Fescue, English Rye Grass, Italian Rye Grass, Bent Grass and Red Top, put up in proper proportions. WE FURNISH FOR \$2.OO PER BUSHEL OF 14 POUNDS.

To this mixture may be added 10 pounds of Mixed Clovers to an acre, consisting of White, Red, Alsike and Mammoth, which, put up in proper proportions, we furnish for $\mathbf{\$ 1 . 7 6}$.

FOr TEMPORARY PASTURE one to two bushels will be sufficient by adding Timothy to the above mixture, and reducing the cost to $\$ 1.50$ per bushel of 14 pounds. Six pounds Mixed Clovers for same, \$1.00.

WRITE FOR SPECIAL PRICES ON LARGE QUANTITIES, 


\section{4 - Currip Bros.' Hortieultural Guide.}

\section{THE LAWN.}

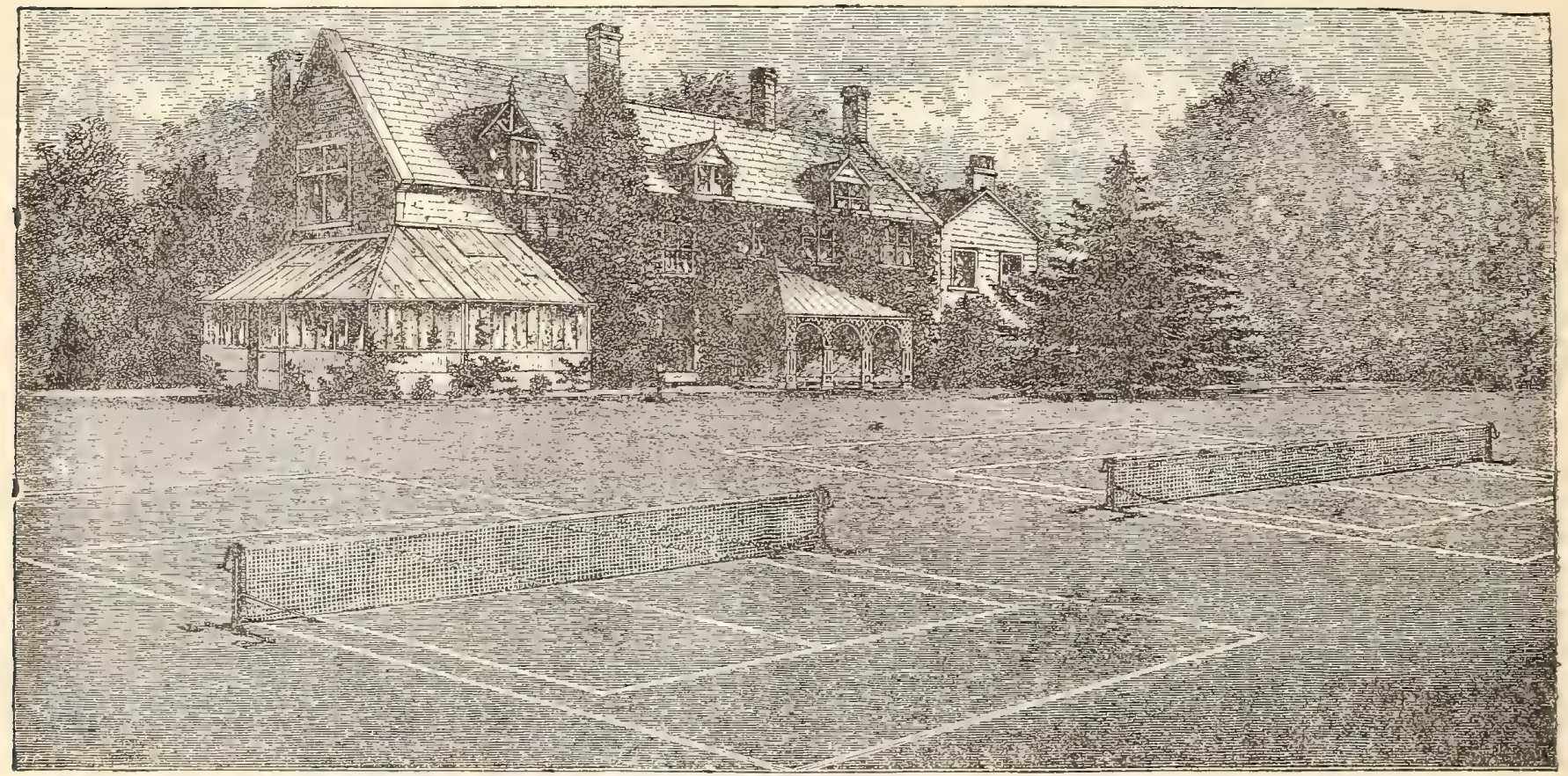

\section{HOW TO MAKE A LAWN.}

A ANY inquiries reach us concerning the best and cheapest method of obtaining a nice, smooth, velvety lawn. We will here 1 describe, as well as our space will permit, the method that gives almost universal satisfaction. The turfing of large lawns is seldom resorted to now ; it is too expensive, and good, clean turf is almost unobtainable. Seeding is the plan usually adopted, and the one recommended by all good landscape gardeners. With that we will deal. When practicable, the soil of the proposed lawn should be thoroughly prepared in the fall. After the necessary grading has been accomplished and the general formation of the surface established, let it all be again thoroughly plowed, harrowed and well pulverized and finally raked to a smooth, even surface-as smooth as possible and firm ; not only that, but alike compact in every spot, to prevent unequal settling. This inay be accomplished by treading down and again filling up to grade where necessary. Scatter over the surface of the ground, if somewhat poor, a coating of rich manure, and let it remain all winter. In the spring remove the manure and again rake the ground smooth and even and sow on the seed. There is much diversity of opinion regarding the proper quantity of seed required for a given area. We are always disposed to advocate a liberal quantity, for the simple reason that as the seed is but a very small item of the expense of making a lawn, and as it is always desirable to have a thick, close turf as soon as possible, it is advisable to sow thickly. With thick sowing we can accomplish in one season what with thin sowing may take two or three seasons, or even longer, to the bitter disappointment of the owner. We have had a very extensive experience in the seeding of lawns. Gradually we have increased the quantity of seed until now we use at the rate of about four bushels to the acre, or a little over one bushel to every 100 feet square, and with the most satisfactory results. Finish off by rolling with a moderately heavy lawn roller, and patiently await the results. If everything is favorable, a nice green lawn about the first of August will be the result. Run the mower over it frequently and remove all obnoxious weeds. The first season the grass may be a little thin, but one season more will make it as thick and velvety as the best of turf. If the grass appears very thin in spots, sow on these a little more seed the following spring.

\footnotetext{
CAN BE SOWN AT ANY SEASON OF THE YEAR.
}

\section{LAWN GRASS.}

Currie's Special Mixture-This mixture is composed of only the finest grasses, and fully merits the high character it

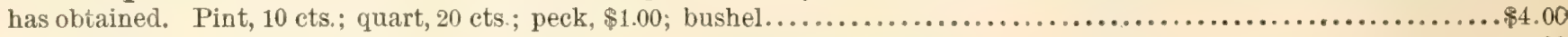

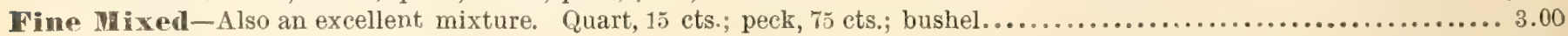
If by mail add 5 cts."per quart to price.

For forming new lawns it is necessary to use 4 bushels to an acre.

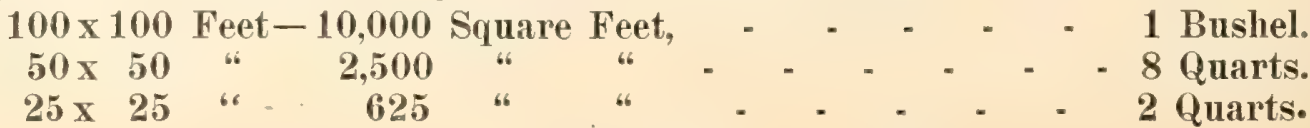




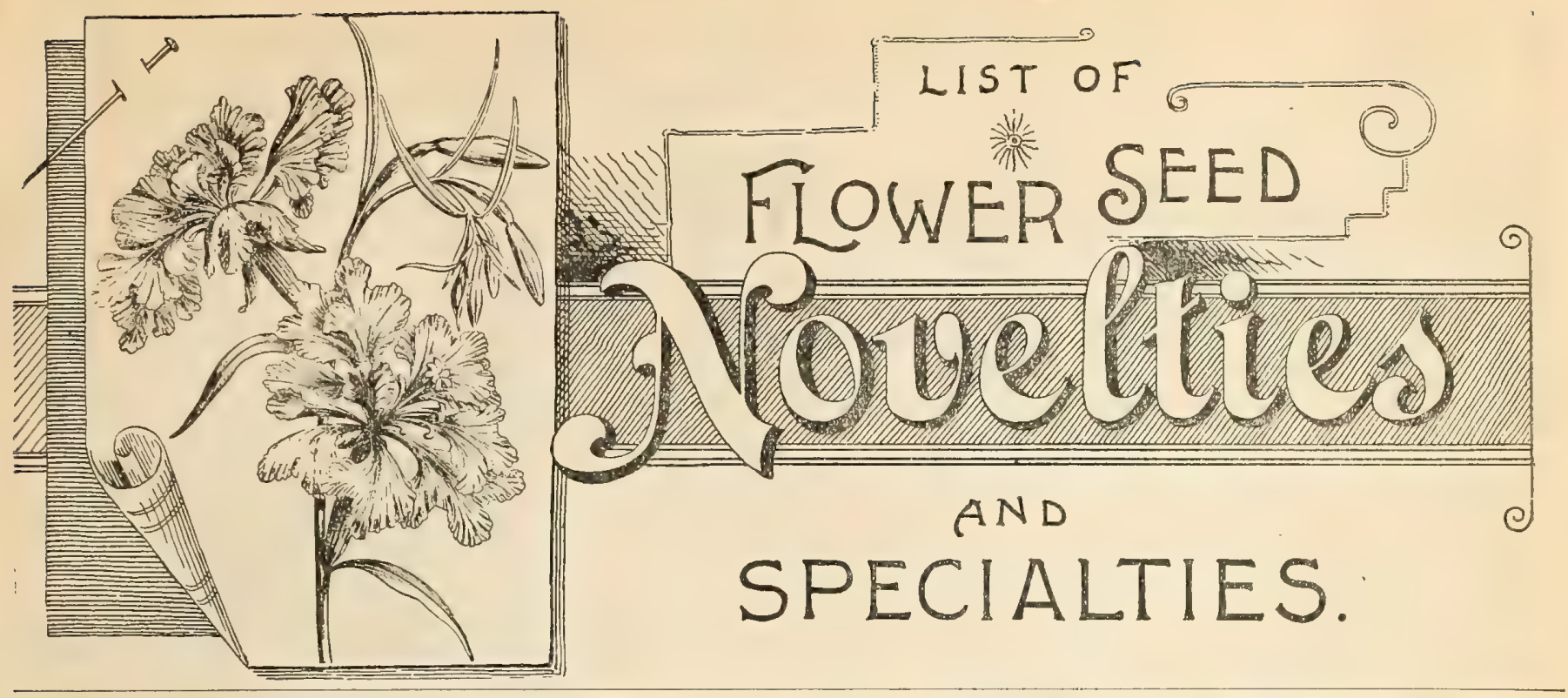

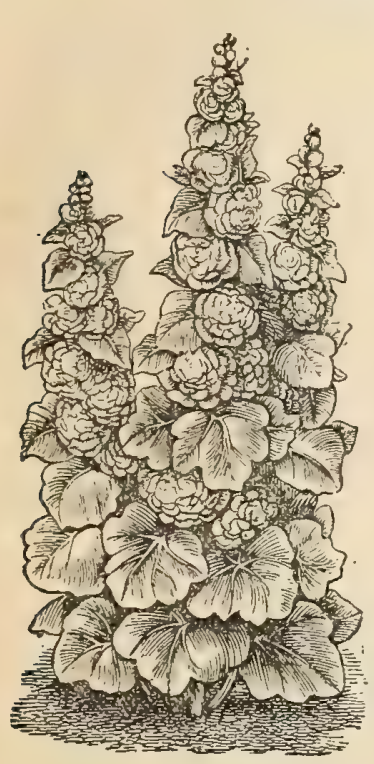

HOLLYHOCK-BLACK PRINCE.

\section{HOLLYHOCK-BLACK PRINCE.}

ATER years of careful hybridizing, we have at $A$ last the satisfaction of offering a genuine black Hollyhock, a variety that cannot fail to meet with general favor. The flowers are a beautiful glossy black color, of fine form, very double, and are freely produced. It is a vigorous grower and re-produces itself true from seed.

Packet, 50 cents.

\section{SWEET PEA-Primrose.}

4 NEW and distinct color in Sweet Peas, and one - that cannot fail to attract the attention of all lovers of this favorite flower. As the name suggests, the color is a primrose yellow, an entirely new shade, making a striking contrast with the many bright shades of pink, scarlet, etc., already in existence.

\section{Packet, 15 cents.}

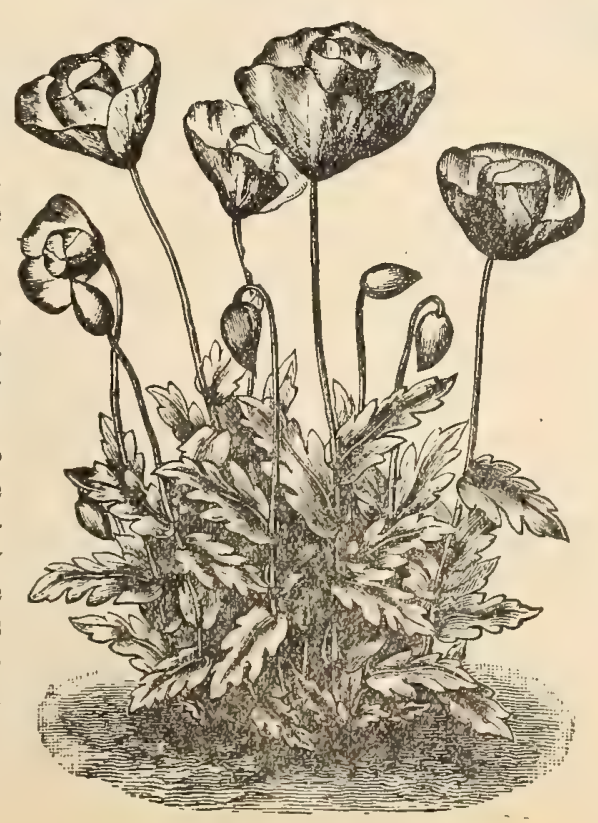

TULIP POPPY - "PAPAVER GLAUCIUM.

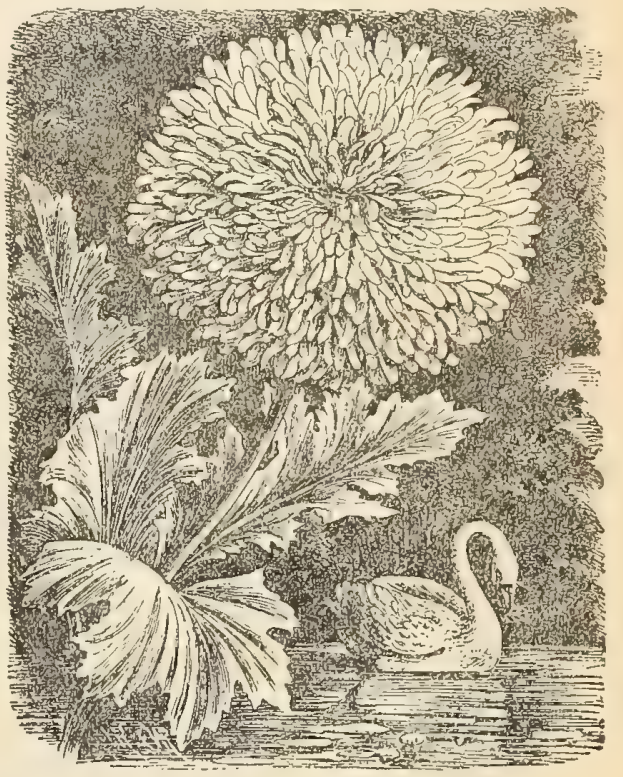

NEW DOUBLE PCRE WHITE POPPY - "WHITE SWAN."

\section{NEW DOUELE}

\section{PURE WHITE POPPY, \\ "White Swan."}

GRAND novelty. The plant grows only $G$ from $1 \frac{1}{2}$ to 2 feet high, forming a dense, richly branching bush, surmounted on strong slender stems by very large, beantifully shaped flowers, very double, laciniated and of the purest possible white. The time of blooming is of much longer duration than that of other Poppies. The luxuriant green foliage and the enormous pure white flowers of this novelty make it particularly valuable for large groups, but it is also very effective planted singly or as a border plant.

Packet, 25 rents. 


\section{Streptocarpus, New Hybrids.}

THIS beautiful new race of Streptocarpus originated at the Royal Gardens striking, scarcely two plants being exactly alike, and the colors range from pure white, pale lavender and all the various shades of blue to deep violet, bright rose and red to rich rosy purple, with all the intermediate tints, and in all the flowers the throat and three lower segments are marked or splashed with long blotches or spots of various shades of purple generally shaded white.

The plant is a greenhouse or indoor perennial of dwarf neat habit, grow; ing about 9 inches high, with long narrow arched and recurved stemless leaves the leaves are of a bright velvety green color, slightly woolly at top and bottom. The flowers, which are very graceful in form, are trumpetshaped, widely open and slightly recurved at the mouth, and measure about $13 / 4$ inches in length.

Packet, 50 cents.

\section{Double Striped Perfection Zinnia.}

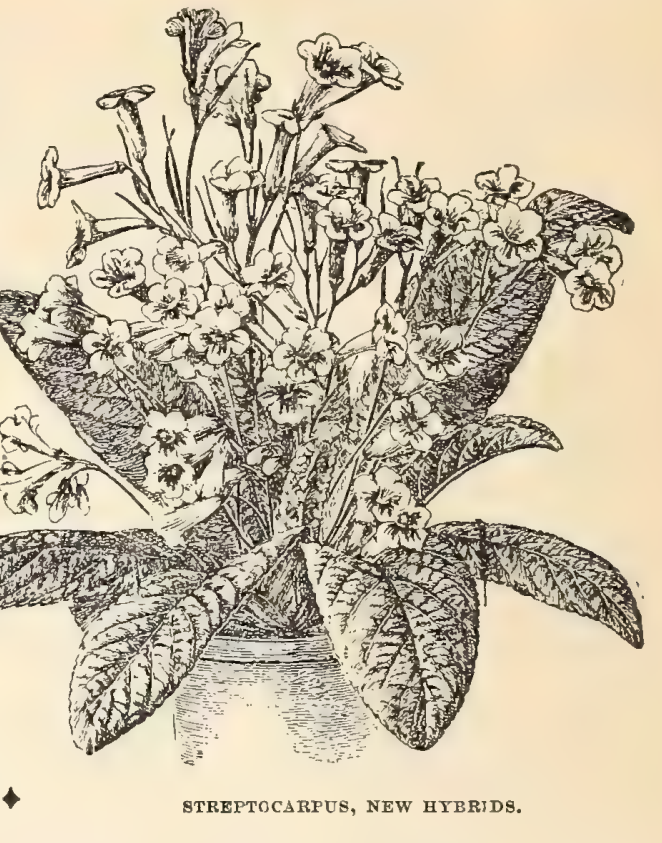

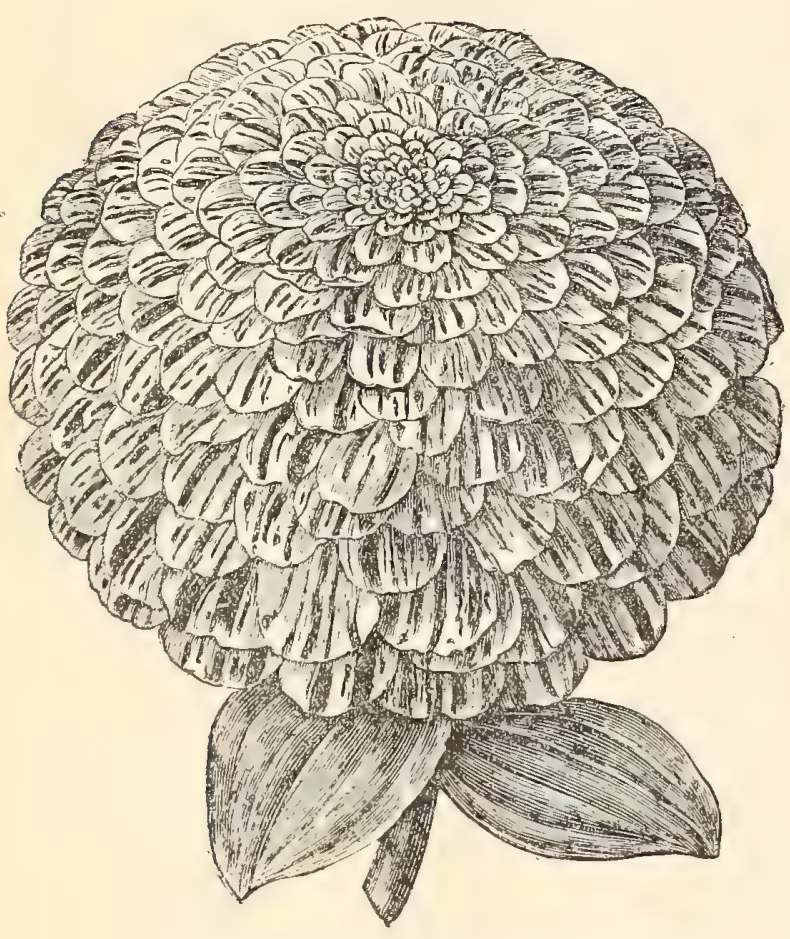

DOUBLE STRIPED PERFECTION ZINNIA.

\section{VICTOPIA TEN WEEK STOCKK.}

I Iandsome new stock of pyramidal shape, flowering A much earlier than any other variety and continuing in 2. bloom until very late in the season. The plant is of robust habit and produces an abundance of bloom, forming a perfect boucuet.

Pure white, - - - 15 cents per Packet.

Dack blood red, 15
I New strain of mammoth flowering Zinnias, far surpassing the Zebra Zinnias in the brilliancy of its markings. The flowers. are large and very double, and of the most novel and charming shades of color, each petal being as distinctly striped or splashed as the most beautiful carnations or dahlias.

Packet, 25 cents.

\section{New Hardy Hybrid Primroses.}

$T^{\prime \prime}$ HIS lovely genus of plants has not received the attention it deserves, and only requires to be introduced to become a general favorite with all plant lovers. For permanent borders and rock-work they are invaluable, making a grand display throughout the season.

They are not quite hardy in this northern latitude, but7if protected with a light covering of leaves or litter, they will live throughout our hardest winters. As a pot plant they are excellent, and may be relied upon to give a profusion of bloom.

The strain we offer is saved from a collection of the newest and handsomest varieties, ranging in color from pure white to dark crimson.

Packet, 25 cents.

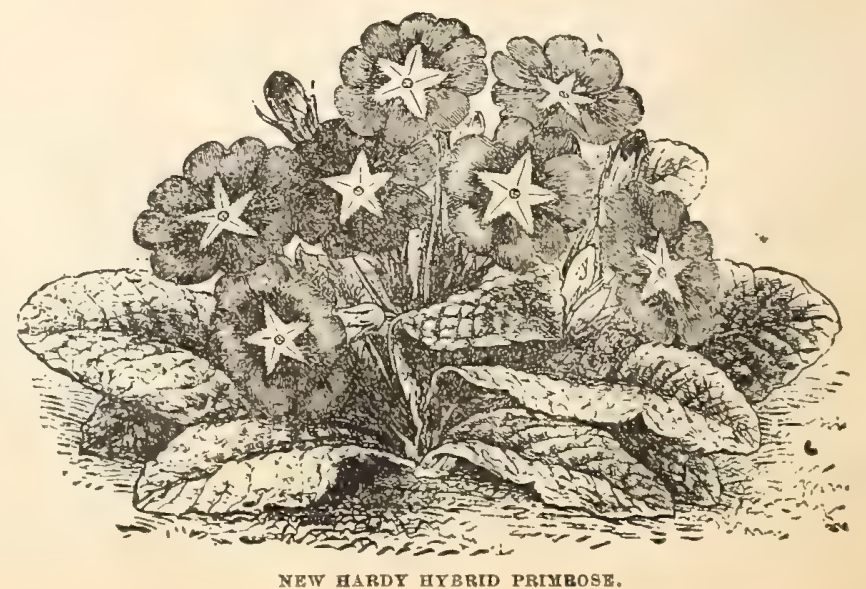




\section{PHLOX DRUMMONDI SEMIPLENO.}

I New and novel strain of semi-double Phlox containing many new and beautiful tints, such as pale pink, yellow, rose, marbled rose and violet purple, besides the usual colors-white, searlet, purple,

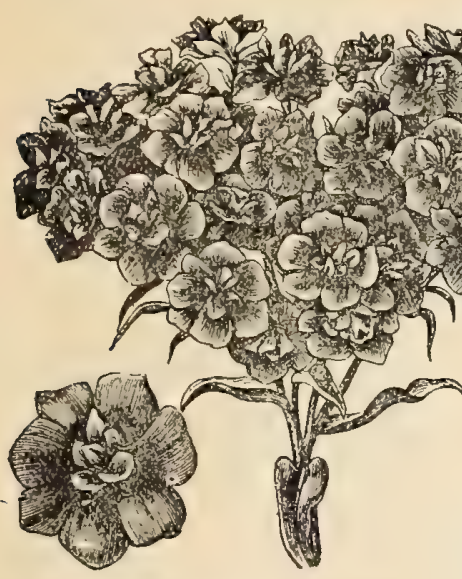

PHLOX DRUMMONDI SRMIPLENO. etc., making a valuable addition to the numerous varieties already in cultivation.

All lovers of this beautiful annual must necessarily hail this new strain with delight.

Packet, 2oั cents.

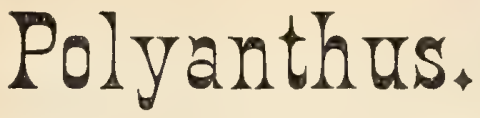

FARLY spring flowering plants ither for out-door or pot culture, The strain we offer is selected from a very choice collection of the new-

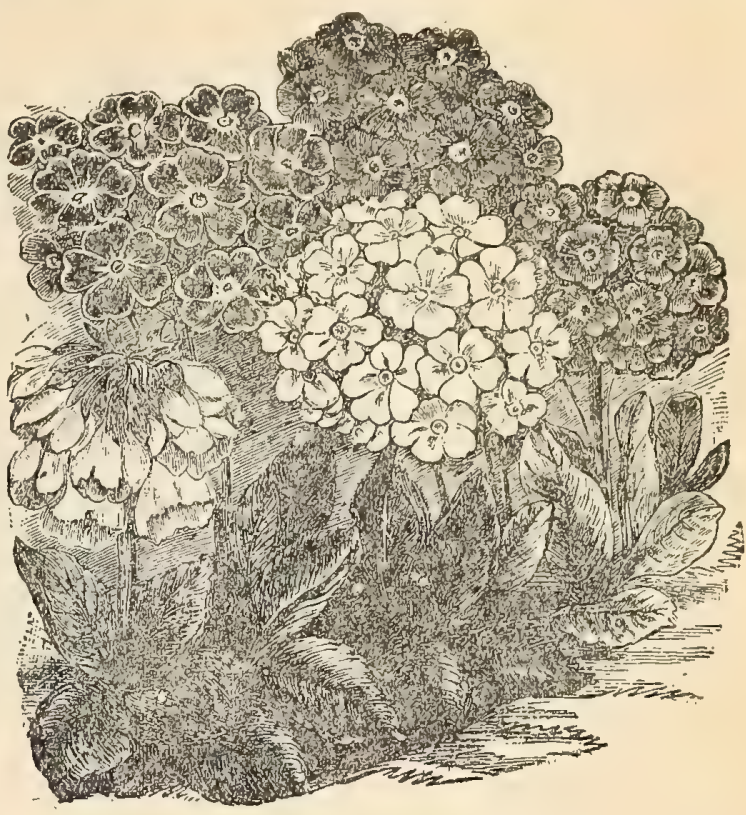

TOLYANTHUS.

est and best sorts in beautiful colors, ranging through the various shades of yellow, crimson, maroon, ete., all handsomely marked. As a pot plant they cannot fail to give satisfaction, blooming as they do very profusely, and for out-doors in the open border or rock work they will be found equally as desirable, requiring only a light covering of leaves to protect them through our severest winters. Packet, 25 cents.

\section{BEGONIA-SEMPERfLORENS Atropurpureus.}

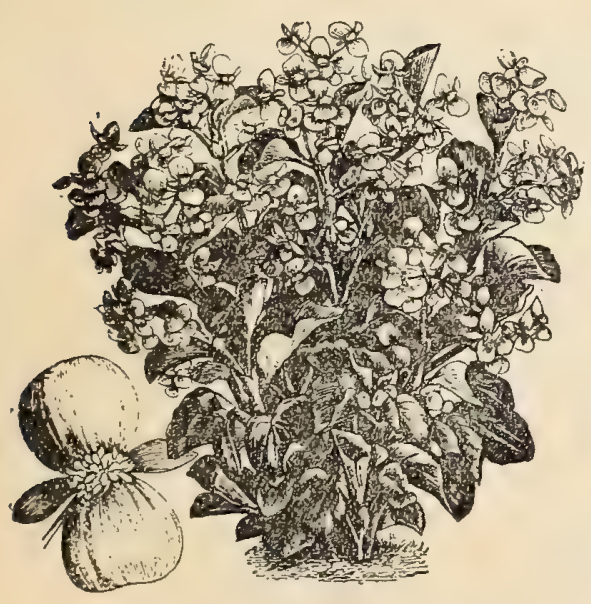

BEGONIA-SEMPERFLORENS ATROPURPUREUQ.

- Beautiful Begonia similar in habit to the well-known Semperflorens. It

c. Lowever surpasses the latter by far, by its brilliant orange carmine flowers, and by its glossy brownish red foliage; the deep tint growing in intensity as the season advances. The beauty of the male flowers is still enhanced by the bright yellow stamens which contrast admirably with the brilliant red flowers and the dark metallic leaves.

Blooming in the greatest profusion throughout the summer and autumn, it cannot be too highly recommended.

Packet, 2 j cents.

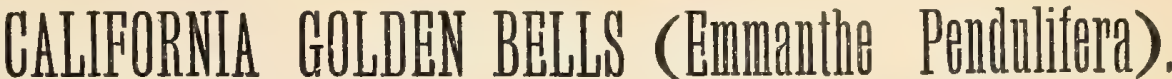

$\triangle$ Novelty from California form$H$ ing bushy plants 9 to 12 inches high. Each branch is loaded with bell-shaped pendulus flowers, about $1 / 2$ inch long, of creamy yellow color, foliage pinnatifid.

The general effect of a branch is very suggestive, of long spikes of Lily of the Valley. Packet, 25 cents.

\section{CURRIE'S SUPERFINE SCQTCH PA PANSY,}

THIS beautiful strain of Pansy is saved from varieties that have received the first premium at the International Flower Shows of Great Britain and other prominent exhibitions for a number of years, and to-day it remains pre-eminently the finest strain of Pansy in cultivation. It is unexcelled by any in size of flow er (many of the single blooms measuring over 3 inches across), and for richness of color and beautiful markings it has no equal. Scotch growers have for many years excelled those of any other nation in producing fine Pansies; not only is their climate peculiarly adapted to the cultivation of the Pansy, but it has long been esteened by them as one of the most beautiful of flowers, and great care has been taken in perfecting it. Packet, 25 cents.

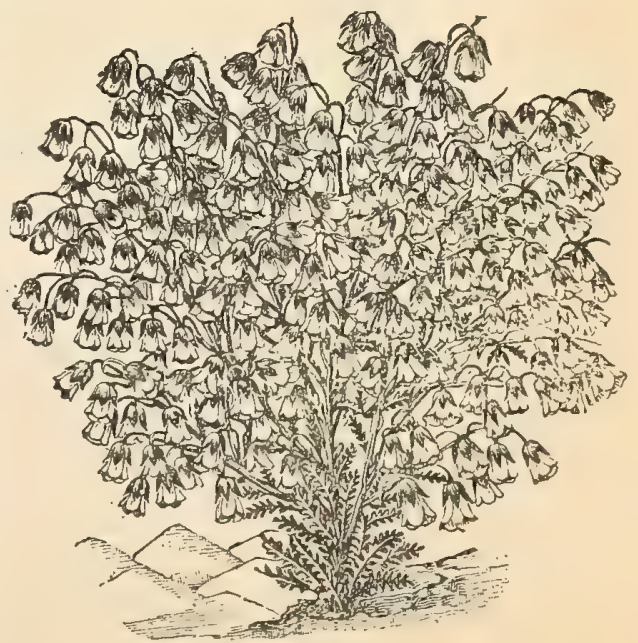




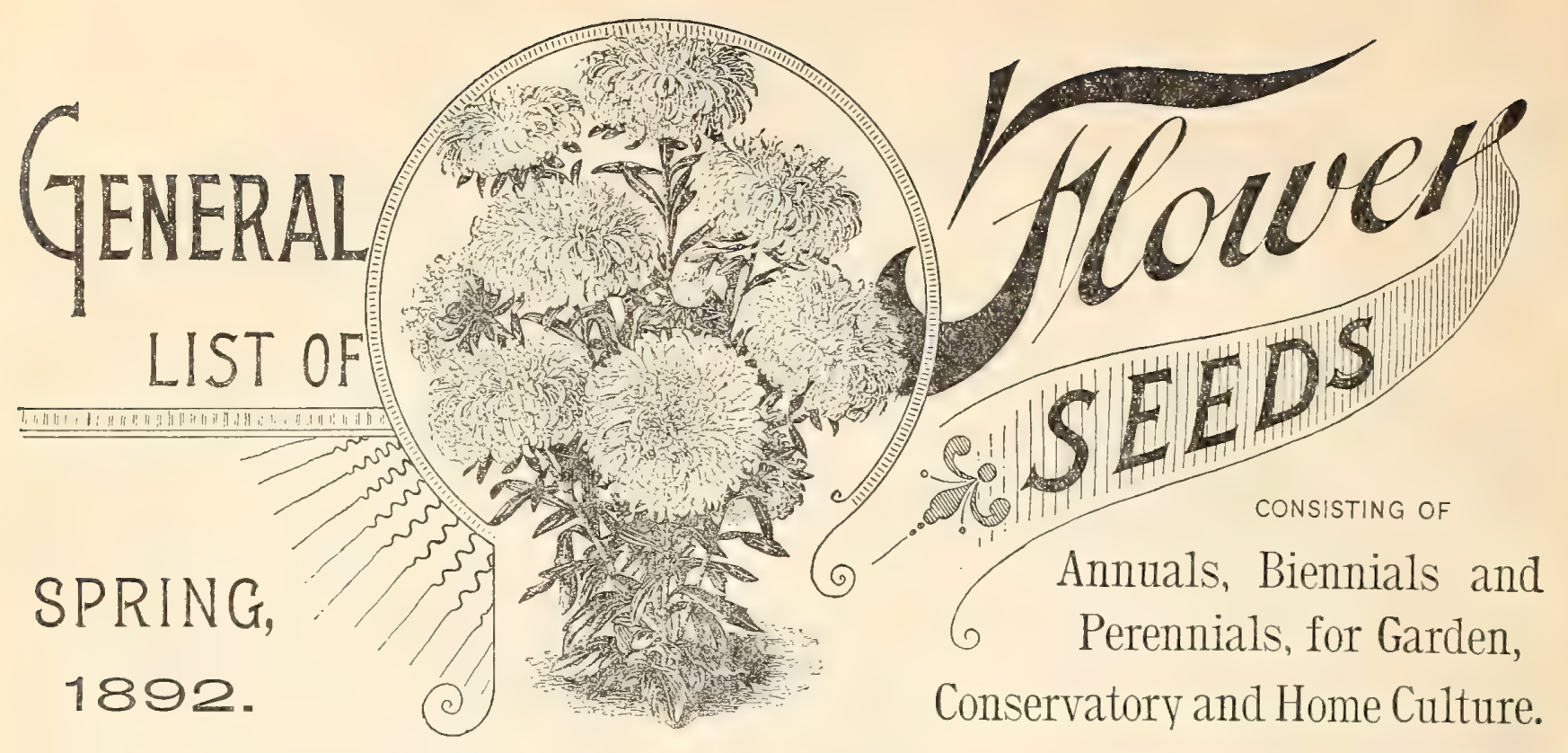

\section{ALL FLOWER SEEDS DEIIVERED FREE BY MAIL.}

MANY years of practical experience in Floriculture has enabled us to faithfully discriminate between those 12 Hlowers which are truly excellent or well worthy of cultivation, because thoroughly adapted to our climate, and those of no value to us, however beautiful and well-suited they may be to other countries. Greenhouse plants may be grown with like success in any climate ; but while it is true a very large number of kinds will succeed as well in one climate as in another, there are certain very choice kinds, very beautiful and very desirable, but which only do well under the most favorable circumstances. They may be found in perfection in one place, but try as we may, we invariably meet with failure in attempting to grow them in a climate less favorable. Our general list of flower seeds contains all and only these of most value in our climate. If we introduce any new thing, we must either know it well ourselves, or be thoroughly convinced by what we learn of it from the most reliable sources that it is worthy of culture, before we will list it. We use every care our experience can suggest to have our flower seeds true to name and of the very best quality. With the proper treatment and care every seed must grow. To assist the uninitiated we give brief but sufficient directions for the culture of each plant on the seed packet, which, if faithfully followed, will surely result in success.

The following Abbreviations occur in the Flower Seed List, viz:

A for ANNUA ES that grow, bloom and die the first year from seed.

$\mathbf{B}$ for BIENYLALS that bloom the second year from seed, and then die, although many, if sown early in the Spring, will flower the first year.

P for PERENNIALs that usually bloom the second year from seed, and continue to grow and bloom for many years. Some will also bloom the first year if sown early.

H indicates they are HARDY, and H HALF HARDY. T indicates that they are TENDER.

HARDY Annuals, Biennials and Perennuals can be sown in the open ground early in the spring, and Biennials and Perennials do not require protection in Winter.

HALF HARDY Annuals, Biennials and Perennials should not be sown in the open ground until warm weather sets in; they can be sown in the house if desired early, and afterward transplanted. The two latter need to be protected in the Winter, or carried over until spring in cold frames or greenhouses.

\section{HON TO FCONOMTZE.}

\section{"A PENNY SAVED IS A PENNY EARNED."}

As an inducement to purchasers of our seeds IN PACKETS ONLY, we make this MOST LIBERAL OFFER, but we wish it thoroughly understood that it applies to orders for seeds in Packets only, and not to orders for an ounce or more.

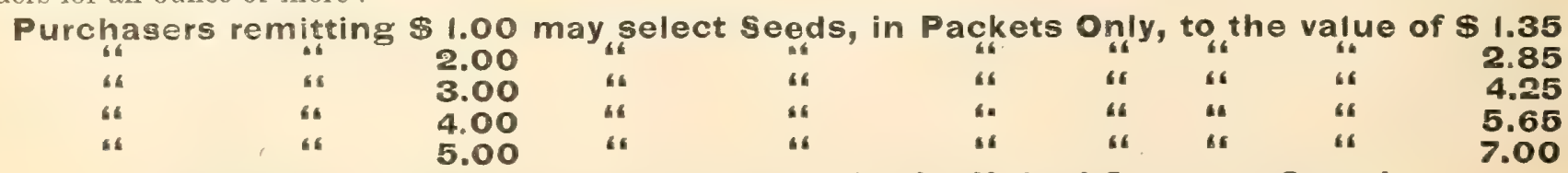

Delivered free by mail to any address in the United States or Canada. 


\section{Currie Bros.' Hortieultural Guide.__ _ _}

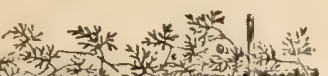

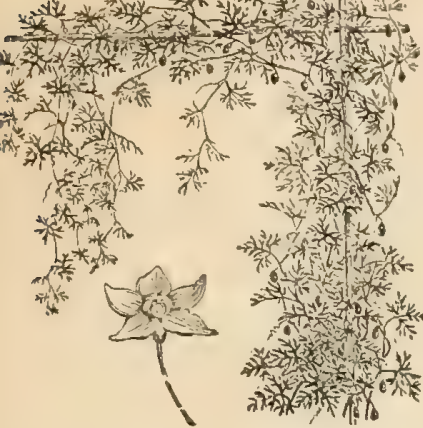

ABOBRA.

Virdiflora-A rapid-growing and exceedingly beautiful climbing Gourd, producing freely dazzling scarlet fruits, which form a striking contrast against the dark, glossy green of the foliage.

H. H. P.

\section{ABUTILON.}

One of our best greenhouse plants, flowering freely during the spring and winter months; the flowers are bellshaped, and in most of the varieties are to be fonnd crimson grounds streaked with yellow; yellow grounds veined red; pure white and clear yellows. Sown before April, they will bloom the first season. P.

Fine mixed of above shades, 2 to 5 feet.

George's Hybrids-Tery choice.

\section{ABRONIA.}

Pretty little plante resembling the Verbena in their style of growth. The flowera are very fragrant, and especially so in the evening. H. H. A.

Arenaria-Waxy yellow, $1 / 2$ foot

Umbellata-Rosy lilac, $1 / 2$ foot.

\section{ACACIA.}

Very desirable plants for greenhouse or conservatory culture, but in this country of no special value for open-air planting. The flowers are formed in thick clusters on long spikes. Soak the seed in warm water several hours before sowing. Greenhouse shrubs. P.

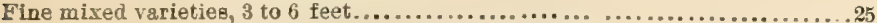

\section{A CHIMENES.}

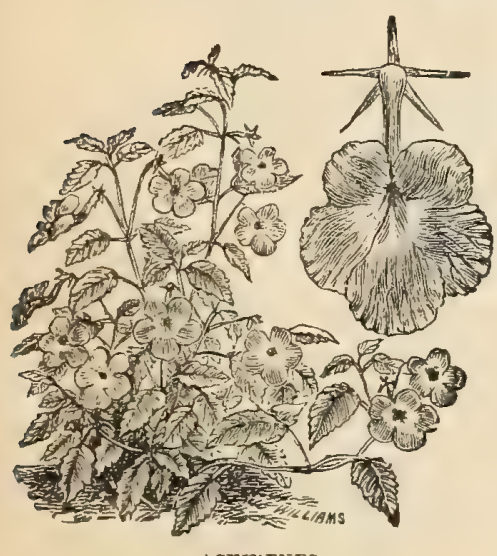

Very handsome tuberous-rooted greenhouse plants, producing flowers of almost every imaginable shade and color. $P$.

Choice mixed.

\section{ACHILLEA.}

Ptarmica, fl. pl.-An excellent plant for borders. The flowers, which are the purest white and very double, are produced in the greatest profusion through out summer and autumn; fine for cut flowers. H. P. 1 1 $1 \frac{\mathrm{ft}}{\mathrm{ft} . .15}$

\section{ACROCLINUM.}

A beautiful everiasting flower, resembling the Rhodanthe, but larger. Cut the flowers, for winter bouquets before they are fully open. H. H. A.

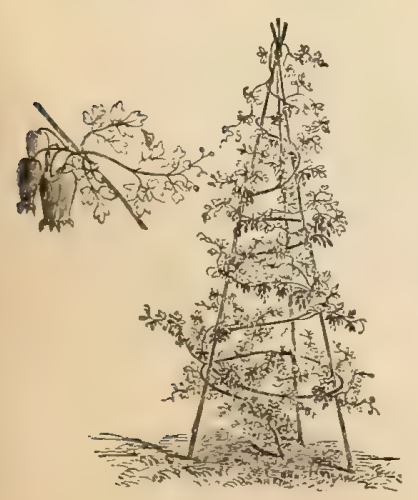

Album-Pure white, 1 foot ......... 5 Roseum-Bright rose, 1 foot.......... 5 Roseum fl. pl.-Double rose, 1 foot...10 Album fl. pl.-Double white, 1 foot....10

\section{ADLUMIA.}

An attractive climber, well worthy of a place in every garden. The flowers are flesh-colored, and form a fine contrast to the pale-green foliage of the plant. H. B. Cirrhosa (Mountain Fringe or Alleghany Vine)-Flowers flesh white, 15 feet $\ldots \ldots \ldots \ldots \ldots \ldots \ldots \ldots \ldots \ldots \ldots$

\section{AGERATUM.}

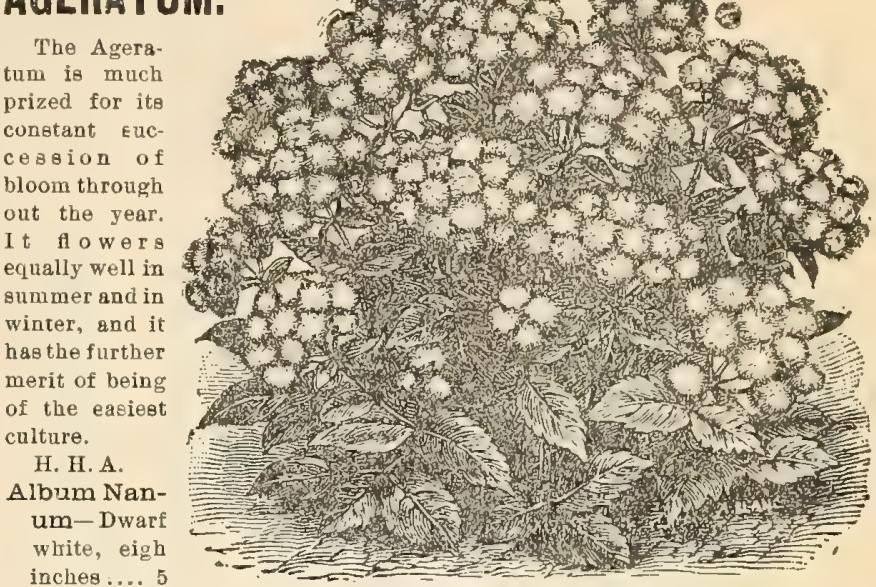

I $m$ p e $r$ i a 1

Dwarf Blue

AGERATUM-DWARF WHITE,

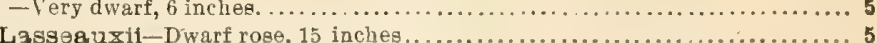

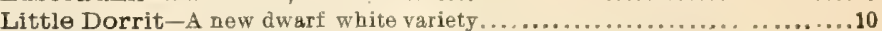

Mexicanum-Lavender blue, 2 feet.......................... 5

Mexicenum Nanum-Dwarf blue, 8 inches..................... 5

Tom Thumb-Very dwarf blue, 6 inches............................ 5

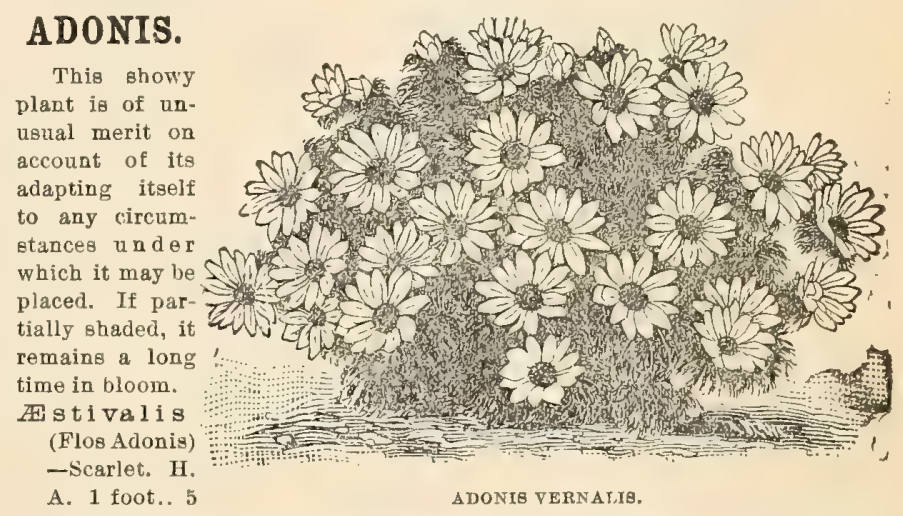

Autumnalis (Pheasant's Eye)-Crimson. H. A. 1 foot.............. 5

Vernelis-A hardy variety with large yellow flowers. (See cut.) H. P.9 inches.10

\section{AGROSTEMMA.}

Hardy, herbaceous plants; free flowering and attractive. H. A.

Cæli Alba-Pure white, 1 foot.

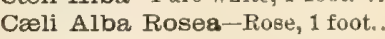

Bicolor-Mixed.

\section{ALYSSUM.}

The delicate, honey-like fragrance of the flowers of this little plant, so much prized in bouquets and baskets, renders it most unlikely that this old favorite will ever be cast aside.

Little Gem-A new dwarf white variety.

H. A

.10

Sweet

H. A. Per oz.,

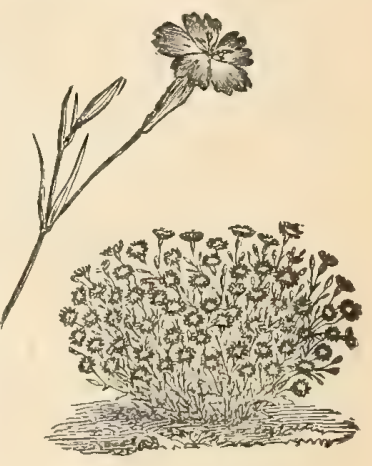

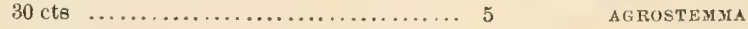

Saxatilø Compactura-Of compact habit; golden-yellow flower's. H. P.

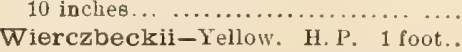

$\ldots 5$

\section{AMARANTHUS.}

A class of highly ornamental plants, many of which are grown exclusively for their handsome foliage, while others are equally desirable for their beautiful clusters of brilliant colored flowers, which ase very effective for autumn decoration. H. H.A.

Atropurpureus-Blood-red fuliage, drooping flower spike................ Bicolor Ruber-Foliage green and dark-red, tipped with yellow; 3 to 5 feet. 5 
AMARANTHUS-Continued.

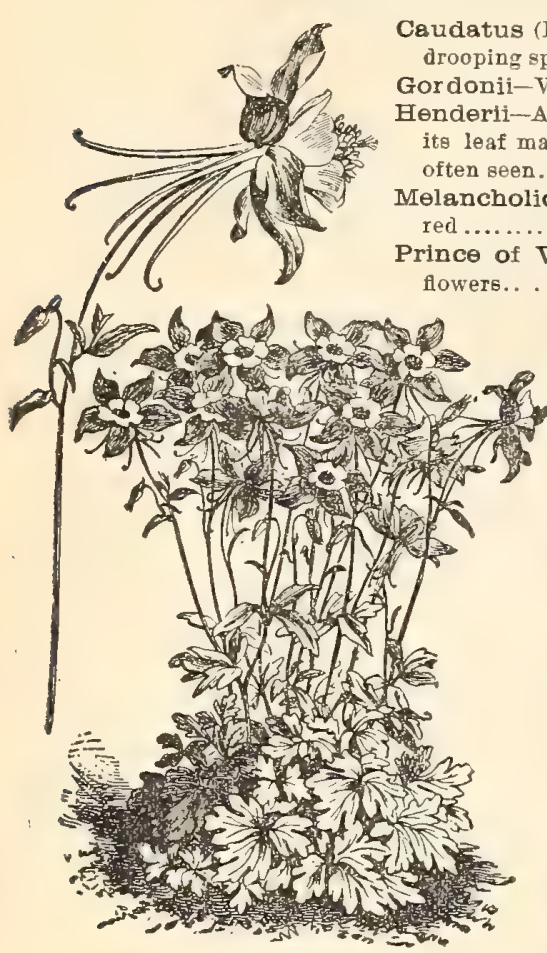

AQUILEGIA.

Linifolla Gracilis-A new dwarf compact variety inches................. 5 Myrtifolia-Deep scarlet, 30 inches................................ 5 Warczwiczil-Flowers small, bright scarlet, forming a very pretty spike, 18

inches..........

\section{AттіовтUт.}

Ammobium is a small but pretty little white flower. The plant grows about 18 inches in height: is stiff and angular in appearance. One of the hardiest of the Everlastinge. Very usefu] for making np in winter bouquets. Aletum-White, hardy, 2 feet. .

\section{ANAGALLIS.}

Simllar in habit of growth to the Aubretia, and it will be found equally as useful in rock-work or bordere where low-growing plants are mostly used. H. H.A. Grandiflora Superba-Mixed colors..

\section{ANCHUSA.}

One of the few plants that will do well in shaded situations where the only strikes at certain times in the day. H. P.

Italica (Italian Alkanet)-Blue, 2 feet.

\section{ANEMONE.}

A very pleasing, hardy plant, flowering in early apring. H. $\mathrm{P}$. Coronaria (Poppy Anemone)-Mixed colors, 1 foot.

\section{ANTIRRHINUM-Snap Dragon.}

One of our favorite plants, of the easiest culture, and unsurpassed for snmmer and fall flowering. The strains we sell are particularly fine, and will fairly vie with the Carnation in the variety of their etripes and spots. P.

Mrjus-Choice mixed

Tom Thumb-Dwarf growing, 1 foot.

Picturatum Nanum-New and distinct, comprising a great variety of brilllant colo

Strlatum-Einest striped, various color

\section{AQUILEGIA - (Columbine).}

Exceedingly showy, early blooming, hardy plants, specially valuable for the peculiar formation of their flowers and the great variety of color. H. P.

Chrysantha Grandiflora Alba-A new variety with very large snow-white

flowers, which are produced in great abundance.

Chrysantha-Bright yellow, flowering freely all summer, 4 feet.....

Corvlea-Fine porcelain blue, center petals yellow, 2 feet.

Glendulosa (True)-Blue and white, 11/2 feet.

Skinnerii-Scarlet and yellow, $1 \frac{1}{2}$ feet

Choice Selected Varieties.

\section{AIAPIS.}

An early blooming plant, well suited for borders and rock wark. 표. P. Alpina -White, 18 inches.......................................

\section{ARGEMONE.}

Very showy plants, with large poppy-like flowers. $\mathbf{\text { R. A. }}$

Grandiflora-W hite, very handeome, 2 feet........................

Hunnemannil-Carmine and yellow, 2 feet ........................... s

Mexicana-Yellow, $\approx$ feet.........................

\section{ARMERIA-Thrift, Sea Pink.}

A compact and beautiful hardy plant, largely used for edging. H. P.

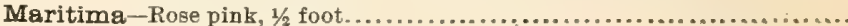

\section{ARISTOLOCHIA-Dutchman's Pipe.}

A rapid-growing hardy climber, growing to a height of thirty feet, with large heart-shaped foliage, and curious heart-shaped flowers. H. P.

Sipho-Yellowieh brown.

\section{ARALIA.}

Sieboldii-A handsome foliage plant. P.........

\section{ARNEBIA CORNUTA-Arabian Primrose.}

An exceedingly pretty annual, producing a profusion of rich primrose yellow flowers about $y_{5}$ inch in diameter, marked, upon first opening, with five black spote, which change the second day to a rich maroon color, vanishing entirely on the third cary, leaving the flower a clear yellow. The eut flower is very effective and keeps fresh a long time in water. The plant grows bushy and about 2 feet high.

\section{AMPELOPSIS.}

Veitchil-"Japanese Creeper," or "Boston Iry." A beantiful, hardy climber......................................................10 AUBRETIA.

Dwarf but ornamental trailing plants, suitable for rock-work or edging. B. P. Deltotdea-Pink,............................................ 10

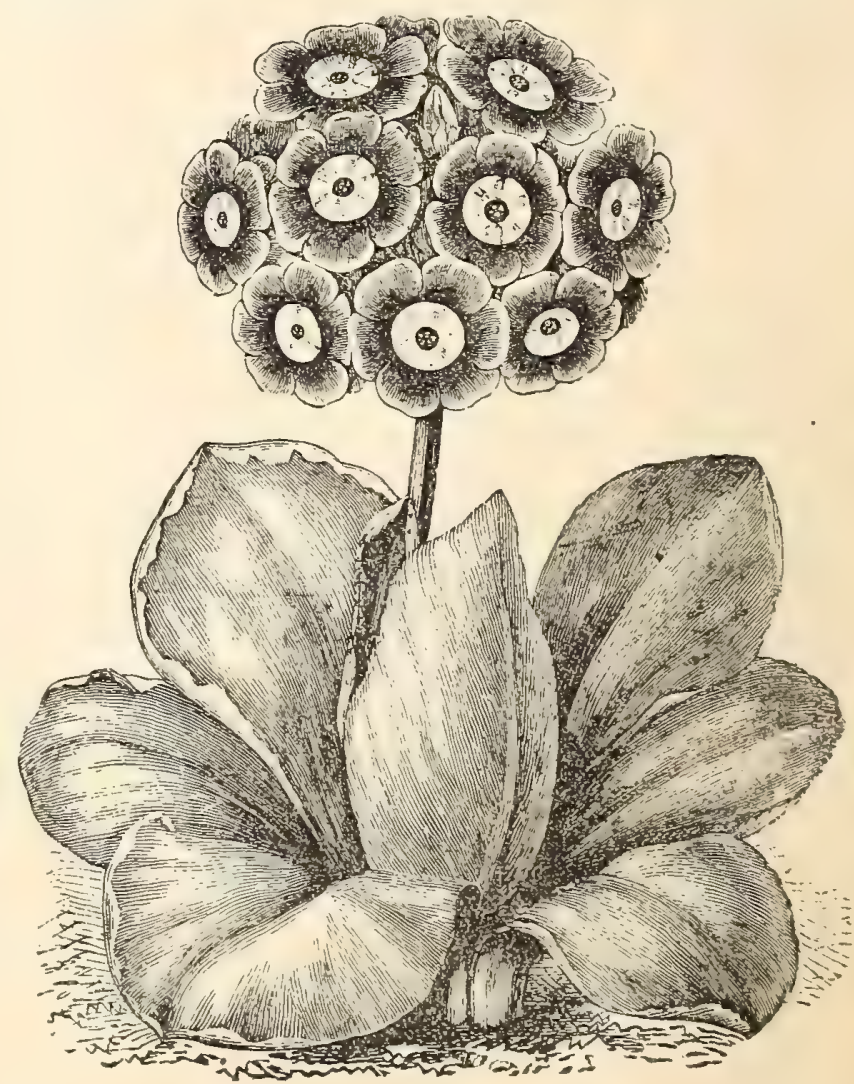

AURICULA.

AURICULA.

Of this beautiful littie plant we have a very fine strain of English-saved seed. The flowers, which resemble the Primrose somew hat, are of rarions shades of crimson, yellow, maroon, etc. P.

Extra choice mixed. 


\section{ASPERULA-Woodruff.}

A pretty little plant, with beautiful flowers; sweet scented. Azurea Setose-Blue, 1 foot. H. A.. Odorata-(Sweet Woodruff)-When dried has a delightful odor, which is Imparted to clothing if put in a wardrobə with then. H. P. 9 inches.......10

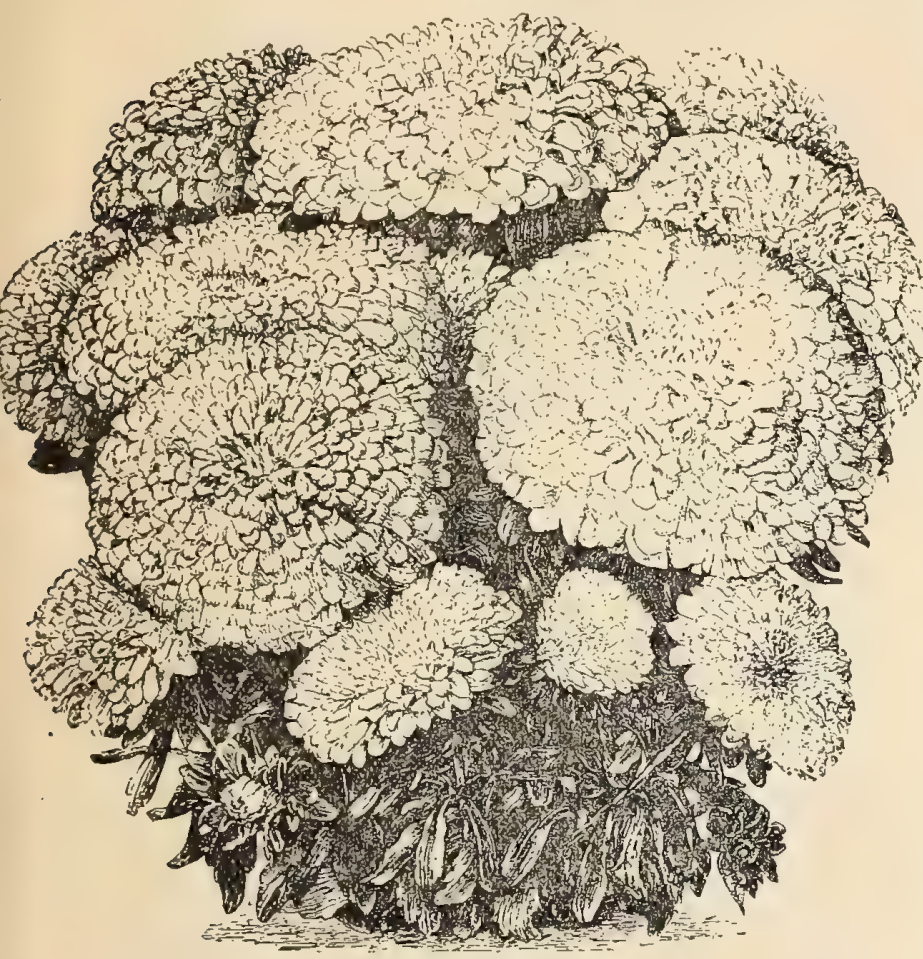

SNOW BALL ASTER.

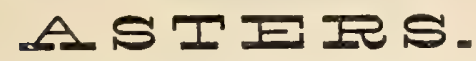

Very beautiful hardy annuals, attaining a height of from 8 to 24 inches. When grown in rich soil they produce in great profusion their exceedingly rich and showy flowers. H. H. A.

China-Fine mixed

Cocardeau, or New Crown-Two colored flowers, the central petale pure

white, sometimes simall and quilled, surrounded by large flat petals of a bright color: $11 / 2$ feet; mixed colors .

Comet-A beatiful new variety resembling the Japanese Chryeanthemum in form; flowers very large and globular, about 4 inches across.

Deep Rose ...................15 i White, with lilac . . . . . . . . . . . 15 Light Blue... ...............15 Rose and white................... Diamond-Is a comparatively new Aster of the Dwarf Imbrique class. Plants $11 / 2$ feet in height, very robngt; blooms freely, flowers perfect and compact, large; mixed colors

Dwarf Chrysanthemum Flowered-A eplendid variety of dwarf, compact habit, 9 inches in height; flowers large, and produced when others are out of bloom.

White to azure blue ....

Flesh color ...................10 Bright rose.....................

Snow white.

Bright scarlet.

.10

Mixed colors

Dwarf Pyramidal Bouquet-Height from 12 to 15 inches; a very fine blooming variety; mixed colors

Golisth-The flowers of this class are of enormous dimensions, and of the most perfect form. It blooms profusely; the plant is of strong, robust habit; 2 feet

Glant Emperor-A very beantiful variety, with very large double flowers, often messuring from 4 to 6 inches in diameter; 1 foot; fine mixed......... 10 Earlequin-A dwarf variety, with striped and epotted flowers................

Hedge-Hog, or Needle-Petals long, quilled and sharply pointed; 2 feet; mixed colors.

Imbricated Pompone-Very perfect, globe shape, and beautifully imbricated; mixéd colors............................................. 10 Ironstem-Pure white flowers, extremely double and finely arched, messuring from 4 to 5 incies in diameter, and borne on remarkably strong stems 16 to 18 inches in height.

\section{JEWEL OR BALL ASTER.}

A magnificent class of Asters which were obtained from the well known Pæony-Flowered Perfection tribe. Similar but somewhat dwarfer in babit than the latter, it distinguishes itself at first sight by its beautiful shorter-petalled and perfectly round flowers, which may be compared to the finest varieties of the incurved claes of Chryeanthemums. The engraving of the single flower showe the noble form of the flowers better than it can be described. The plants attain a height of about 20 to 24 inches. The fully developed flowers, measuring from $2 \frac{1}{2}$ to 3 inches across, are as round as a ball, and being borne on long atalks, thes will prove very useful for cutting. (See cut.)

It comes in three colors

Apple blossom, per pkt..

Deep Rose, per pkt.

Rose with white, per pkt.

\section{ASTER-Ne Plus UItra.}

A now dwarf, very large flowering Aster; is 12 to 14 inches high, has a atout stem, Candelaber shaped branches, forming a perfectly round bush, and presenting their extremely large, fine shaped and very double flowers of Victoria Aster ehape free snd erect to view.

Mixed colors, crimson, white and pink, per pkt

Mignon-A handsome pure white variety, similar in shape to the Victoria;

flowers arched and somewhat larger than the Pompone. .................10

Miniature Bouquet-A dwarf eort, growing from 6 to 8 inches high, and

producing an abundance of very small double flowers.

\section{PFENY-FLOWERED PERFECTION.}

A handsome variety, with incurved petals. The flowers are very large and almost perfectly round; grows about 20 inches high. This is a standard variety for florists' use.

Rose.

10 Pure white......................

Crimson.

Light blue ...

Carmine.

10 Dark crimson

Black blue

10 Peach blossom.

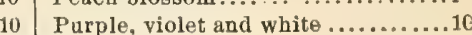

Azure blue.

10 Mixed colors.

Preony-Flowered Globe-The earliest of the Asters-two weeks earlier

than Truffaut'e Pæony-flowered; flowers very large; plant branching and

strong, does not requiresupport ....................................10

Rose-Two feet in height; robust: large flowers; petals finely imbricated and

of great substance; one of the very best; mixed colors....................10

\section{DWARF VICTORIA.}

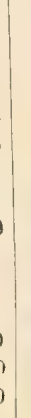

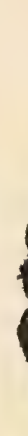
10

One of the finest Asters in cultivation; flowers very large, perfectly double, imbricated and globular; 20 inches in height.

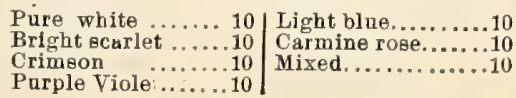

Reid's German Quilled double ; the petals have ance of quillo or $t \mathrm{u}$ be $\mathrm{s}$ : height from JEWEL or BALL ASTE
$11 / 2$ to 2 feet: finest mixed colors 10 -F low er
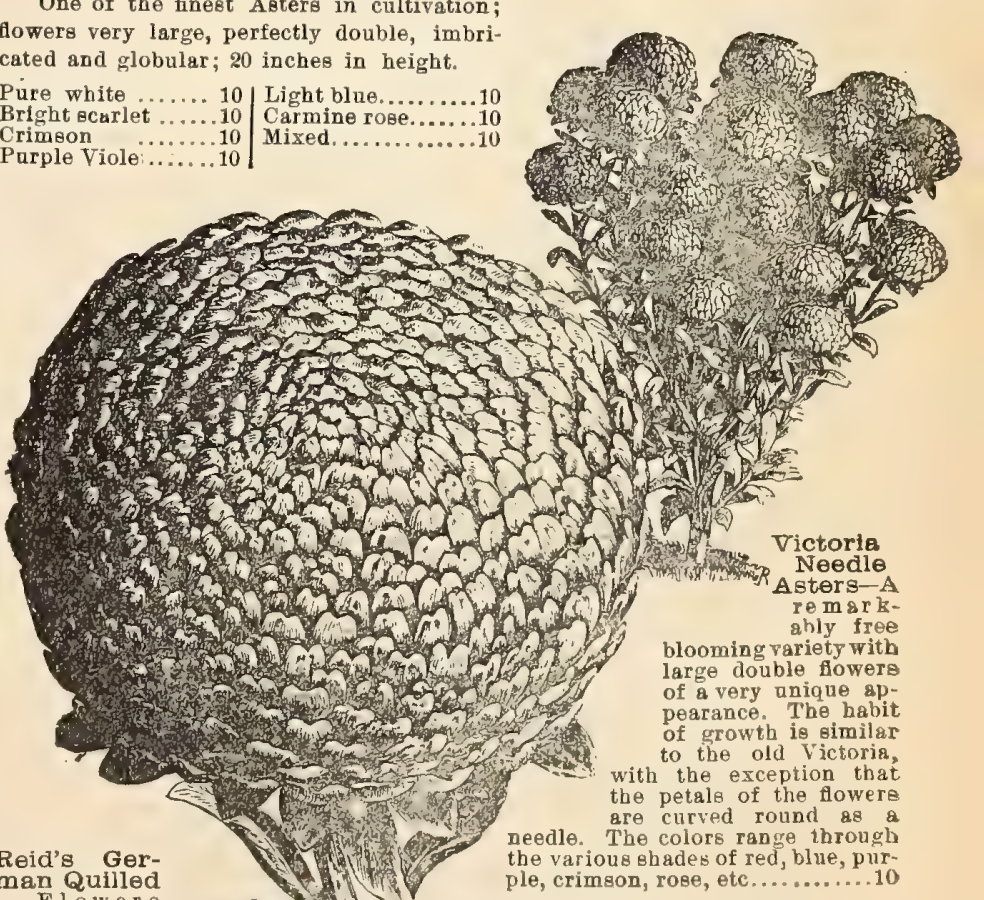

"Snowball," or Princess White-An excellent new dwarf White Aster, prodacing an abundance of flowers, semispherical in form, composed of short very thickly get imbricated petsla, a

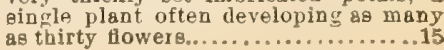


BARTONIA.

Triumph-This is undoubtedly the most beaitiful and perfect of all dwarf Asters. The flowers measure from $2 \frac{1}{2}$ to 3 inches acrose, and are of the most faultless Pæony form, all petals being beautifully incurved. The color is rich and brilliant.

Deep scarlet....................15 | Deep scarlet and white....

Truffaut's Pæony-Flowered Perfection-Very double, of fine form, round as a ball; produces few side flowers; $11 / 2$ feet in height; many colors mixed........

Washington - The largest Aster we have ever known, often 5 inches in diameter and perfect; mixed colors

Washington Needle-Like the well known Washington Aster, this variety produces freely flowers of enormous proportions and of almost every color. Like the Victoria Needie, the petals are curved round like a needle, presenting a beautiful appearance.

NEW ASTER.

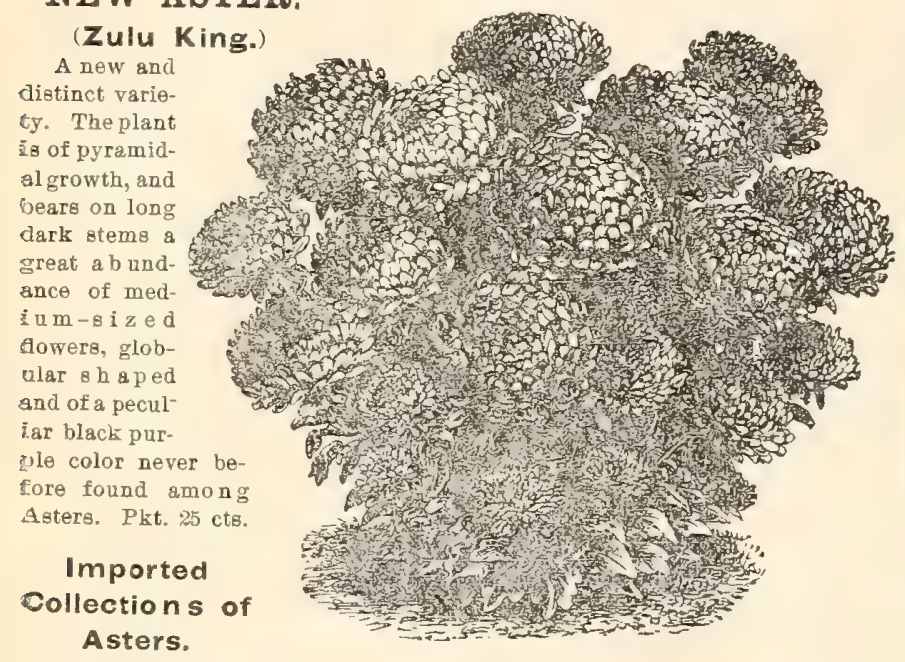

Dwarf Chrysan-

TRIMPE UASTER.

themum-Flowered in 6 separate colors

Dwarf Victoria-In 6 separate colors

Pæony-Flowered Perfection-In 10 separate colors

Fedgehog-In 6 separate colors.

Reid's German Milled-In 6 separate colors

Cocardeau, or Crown-In 6 separate colors.

BALLOON VINE-Cardiospermum.

A curious climbing plant, worthy of attention. H. H. A.

Cardiospermum Halicacabum-White, 5 feet.

\section{BACHELOR'S BUTTON-Centaurea, Cyanus.}

A perfectly hardy border plant, succeeding finely in any common garden soil, but the flowere are more brilliant if grown in gravelly ground. Under cultivation it is really a handsome flower, sporting into varieties of white, purple, pink, particolored, etc.; 2 to 3 feet high. H. A.

Centaurea, Cyanus, fl. pl.-Double flowered Corn Bottle, mixed colors.....10 Cyanus-Single, mixed. Per oz., 25 cts.

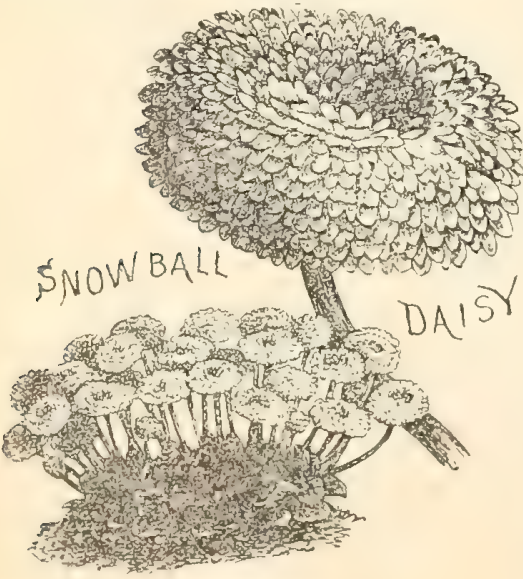

BELLIB.

\section{BELIIS. (Double Daisy.)}

One of the most charming of spring flowere. In bloom from April to June. H. H. P. Snowball-Large, very double, pure white............15

Perennis fl. pl. - Double white .................10 Perennts fl. pl-Donble red................... 10 Longfellow - F low e r s large, dark rose

Perennis fl. pl. - Double mixed....

\section{BETA.}

Ornamental-leaved Beet. A. Chilensis-A beautifully variegated variety...........10
Showy plants, with large, golden flowers, which expand in the hot sun, and are exceedingly brilliant. The foliage is gray and thistle-like in appearance. They require considerable water. Sow seed in open ground where it is intended to flower. H. A.

Aurea-Gulden yellow, 2 feet

Aurea $\mathrm{N}$ ana-Dwarf, golden jellow

BRACHYCOME.

A very pretty dwarf-growing plant, covered all summer with a profusion of Cineraria-like blossoms. H, H. A.

Iberidifolia (Swan River Daisy) - Blue and white, $1 / 2$ foot $\ldots \ldots \ldots \ldots \ldots \ldots$. 5

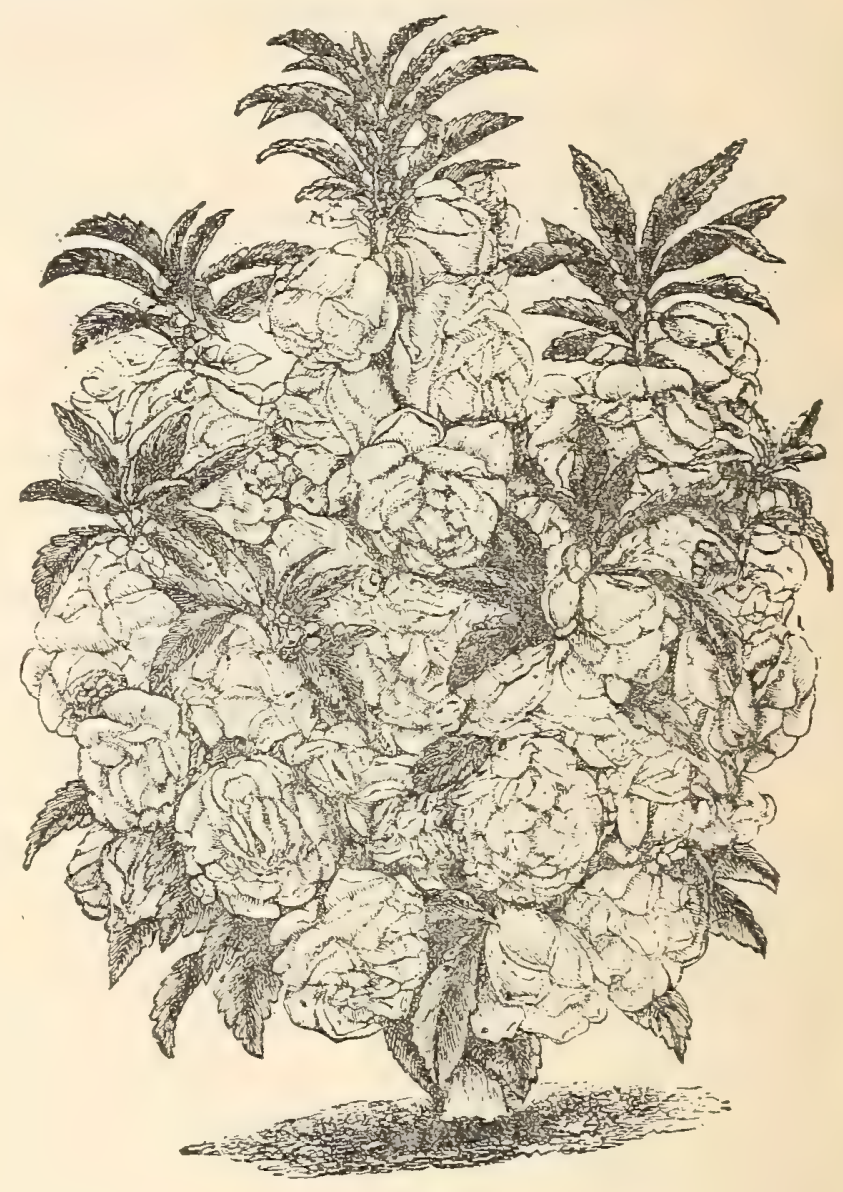

BALSAYI.

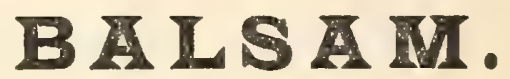

(LADY'S SLIPPER.)

Our customers will be much pleased with all the strains of Balsam that we offer. They cannot be surpassed either in doubleness or in the great variety of colors which they present. T. A.

Camellia Flowered-Finest double, mixed colore, 2 feet................10 Camellia Flowered, Spotted-German, double, spotted with white;

mixed colors ................................................10

Camellia Flowered, White-Extra choice, double ......................

Camellia Flowered-Collection 6 colore, each in eeparate package........50

Rose Flowered-Fine rosy pink................................. 10

Bright scarlet..................10 Pure white.................... 10

Deep blood-red. .................10 10 Collection of 12 varieties...........85

White tinted rose ................10

Double Red...................................................... 5

Double White .............................................. 5

Double Lilac ............................................... 5

Double Peach Blossom .................................... 5

Double Solferins-Beautifuliy striped scarlet and lilac on white ground....10

Double Mixed. Per oz., 40 cts.......................................... 


\section{Currie Bros.' Hortieultural Guide.——}

\section{BEGONIA.}

Plants well worthy of the admiration they receive. For decorative"purposes they are unexcelled. They are alike at home in the parlor or conservatory, bearwith great patience almost any treatment. The Tuberous rooted varieties fo 6 inches in circumference, T. P.

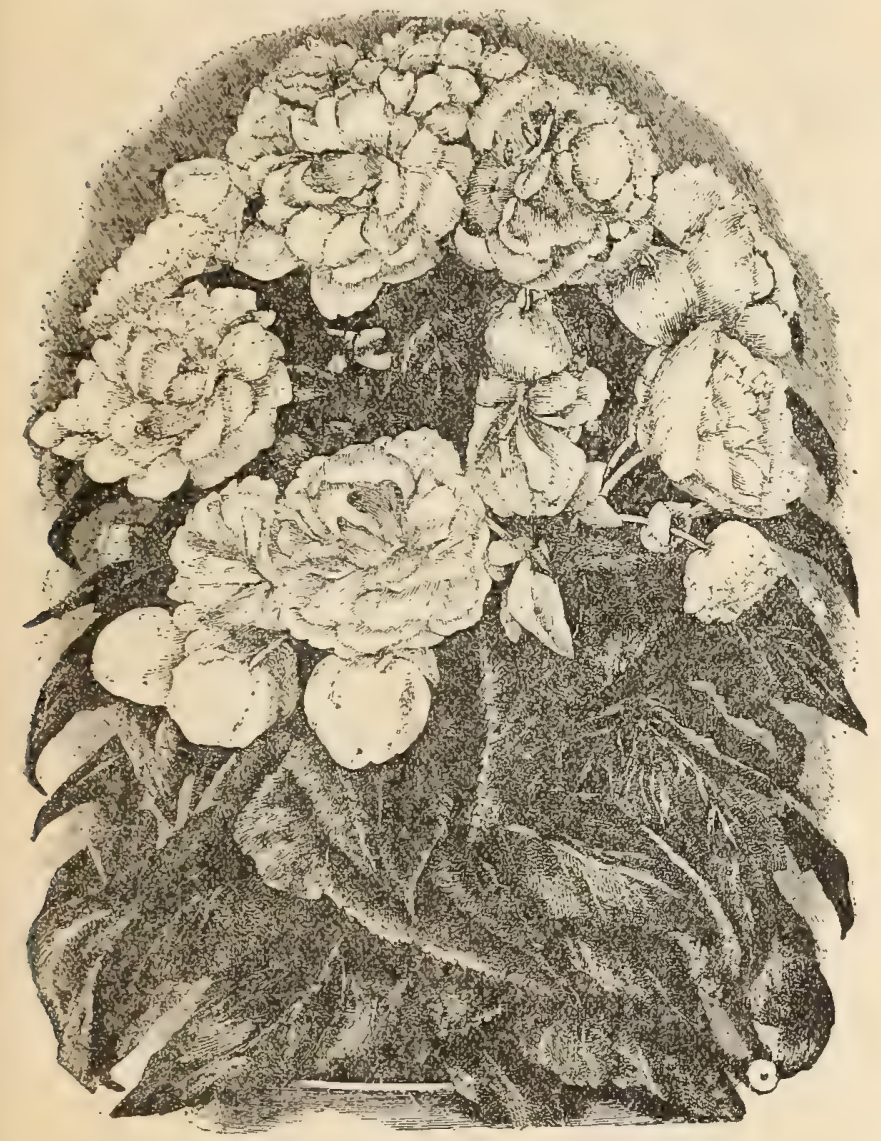

TUBEROUS BEGONIA.

Choice Mized Single-Tuberoug rooted; from prize varieties........25

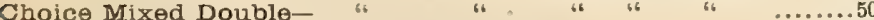

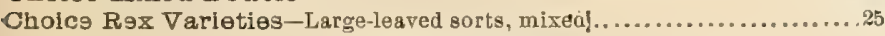

Semperflorens Atropurpurens (see Novelties)...................... 25

\section{BROWALLIA.}

A very handsome, profuse bloomiag plant, growing freely in any rich soil. ㅍ. H. A.

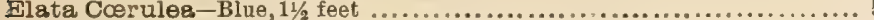

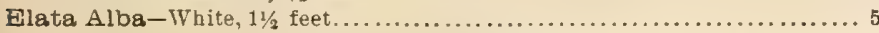

Rozeli-Blue and white; flowers double the size of the preceding sorts......10

\section{BRYONOPSIS.}

A beautifal climber, bearing green fruits which change, as the season advances, to bright ecarlet striped with white. H. H. A.

J.eciniosa Erythrocarpa-10 feet

\section{CACALIA-Tassel Flower.}

Pretty, free flowering annuals, with tassel-shaped flowers, known by some Q.8 Flora's Yaint Brusb. H. A.

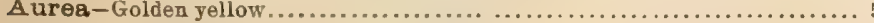

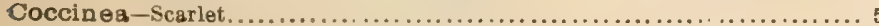
Mixed Colors.

\section{CALANDRINIA.}

Free-blooming creeping plants, suitable for rock-work or edging. H. A.

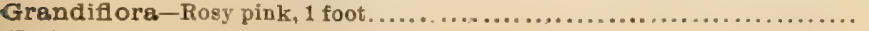
Umbellata $-\nabla$ iolet crimson, $1 / 2$ foot . . . . . . . . . . . . . . . . . . . . . .

\section{CAMPANULA.}

One of our favorite herbaceous plants. All the varieties are strikingly beau"Cup and Saucer Canterbury Bell"-A beautiful variety with large fowers in many brilliant colors, resembling in shape a cup and saucer. $\mathrm{H}$. B. 11 feet.

B.

Torel-Blue and white mixed. H. A. 1 foot.

Sor (Venus' Looking Glass)-Blue. H. A. .

Speculum, Double-Blie. H. A .

\section{CAMPANULA PUNCTATA.}

\section{New Spotted Bell Flower.}

A new hardy perennial, inches high. The flowere, which are bellehaped, milk-white in
atriped with red on the
as large as the well bury Belle, and v r of $u$ gion entire season, until checked by frost. It is a splendid flower cut for vases and bouquets H. P. Per pkt. 15 cts.
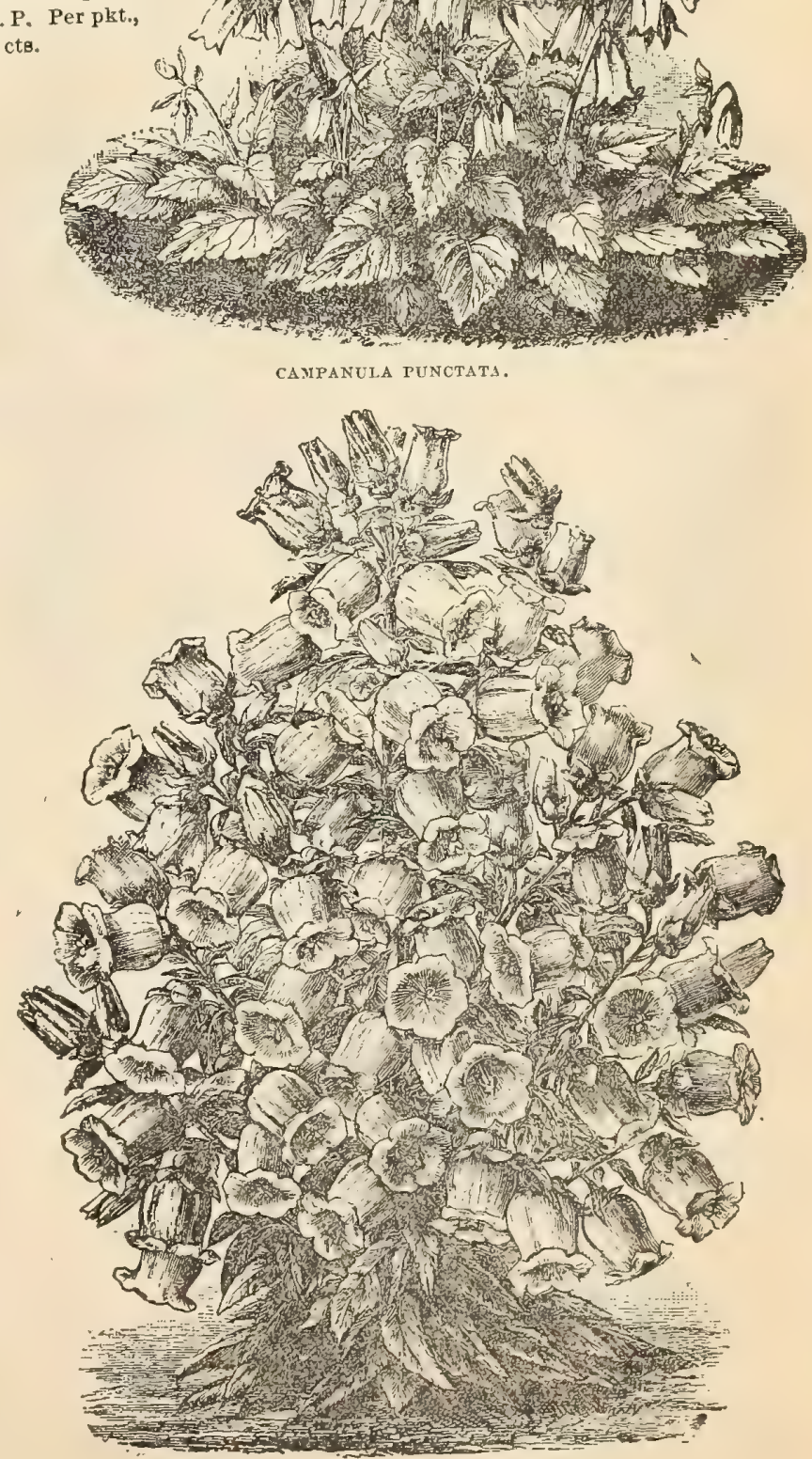


\section{4

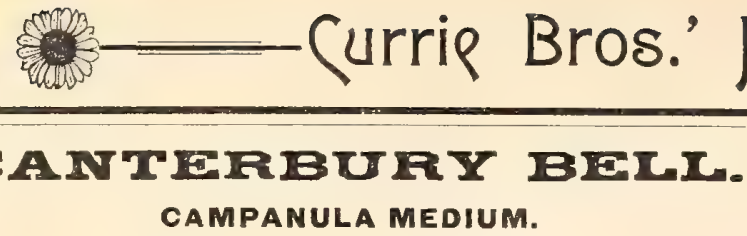

Handsome, of stately growth, rich color and profuse bloom. Succeeds best in light, rich soil, and should be transplanted two feet apart. Their large bellshaped flowers are freely produced throughout the summer, and are strikingly effective. H. B.

Single Mixed-Blue and white

Double Mixed...

\section{CHLCEOLARIA.}

Splendid plants for greenhouse decoration, forming in spring dense maeses of pocket-shaped flowers. Sow in September. T. P.

Hybrida Superba-Saved from the finest formed and most beautifully marked varieties....

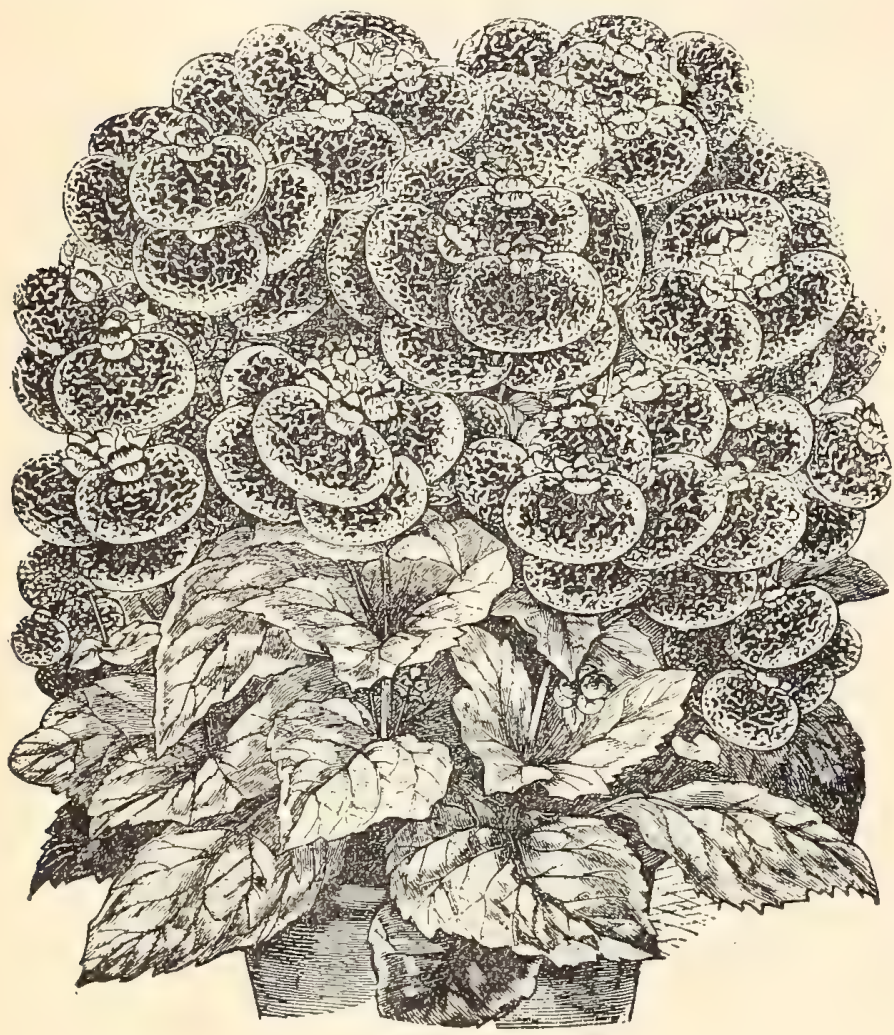

\section{CALAMPELIS-Eccremocarpus.}

A beautiful climber with pretty foliage, and bearing profusely bright orange tubed-ehaped flowers, produced in clusters. It attains a height of ten feet in a вев,

Scaber

\section{CALLIRHOE.}

Dwarf, free blooming plante, continuing in flower throughout the summer and fall. The flowers are purplish with white center. H. A.

Involucrata-With large purplisb, crimson flowers; native of the western prairies . .

Pedata-Crimson purple, with white eye, 1 foot

\section{CANARY-BIRD FLOWER-Tropæolum Pere- grinum.}

One of the most desirable climbing plants in cultivation, growing rapidly to a height of ten feet, and producing an abundance of yellow-fringed Howers throughout the season. H. H. A.

Yellow-10 feet.

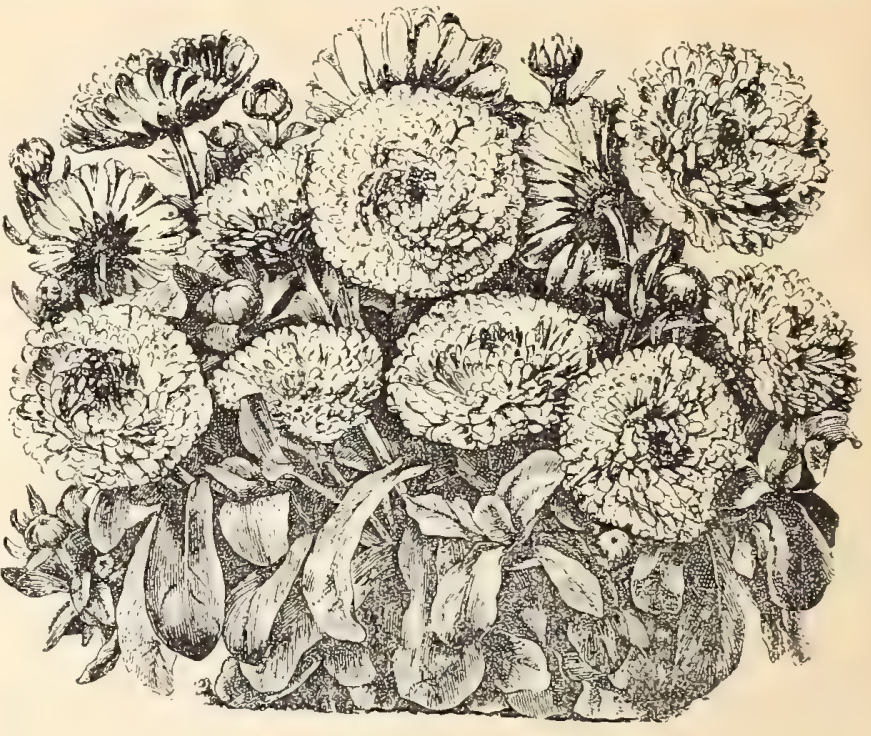

CALENDULA-Cape Marigold.

Attractive and free blooming plante, d ling well in almost any situation. The Pot Marigold, C. Ponge $i$, is much prized as a pot plant. H. A.

Offlcinalis Le Proust-Uniformly double; nankeen; edged with brown.... Officinalis Meteor-A variety very fine for pot culture, bearing light yellow

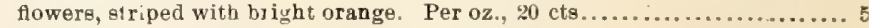

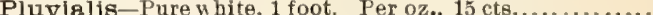

Pongei fl. pl. (Pot Marigold)-Double waite. Per oz., 15 cte...............

Prince of Orange-An improvement on Meteor. The color is a deeper

shade of orange and striped in the same way. Per oz., 25 cts............ 5

\section{CACTUS.}

Curious greenhouse or parlor.plante, some with beatiful flowers, while othere are remariable for their odd-shaped foliage. Fine Mixed........... 25

\section{CASSIA.}

Beautiful plants for the conservatory or window, neat in foliage, and compact in habit; flowers yellow. T. P. Mixed.............................10

\section{CALLIOPSIS, or COREOPSIS.}

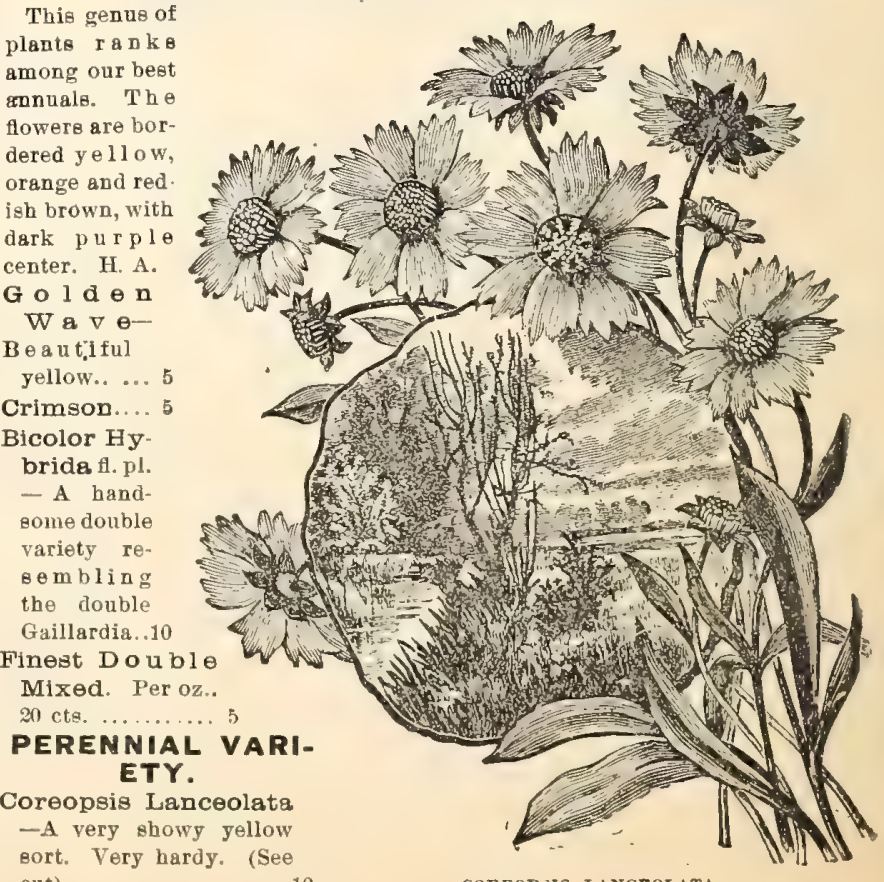




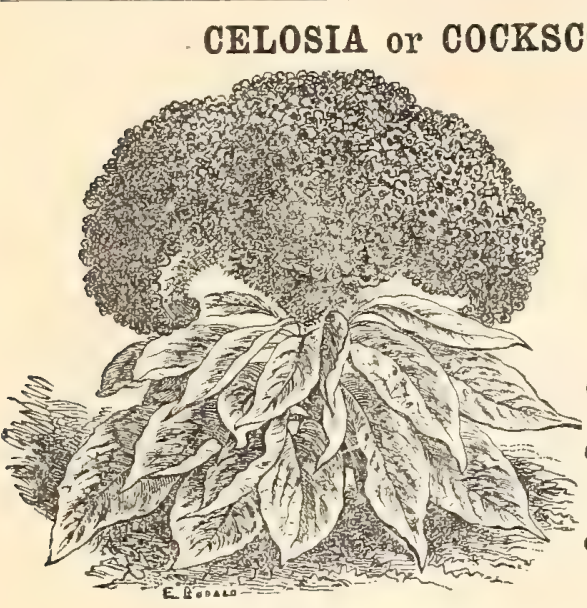

Japonica-A rew and beautiful variety, with crimson branches. The combs, which are exceedingly bright, are as finely cut as ruffled lace.

\section{FEATHERED VARIETIES.}

Pyramidalis Plumosa Aurea-Golden yellow plumes; very fine, 3 feet...10 Reid's Perfection-Contains some eplendid varieties of color

Reine des Orangee-A beautiful dwarf variety, brilliant orange, leaves shaded brown.

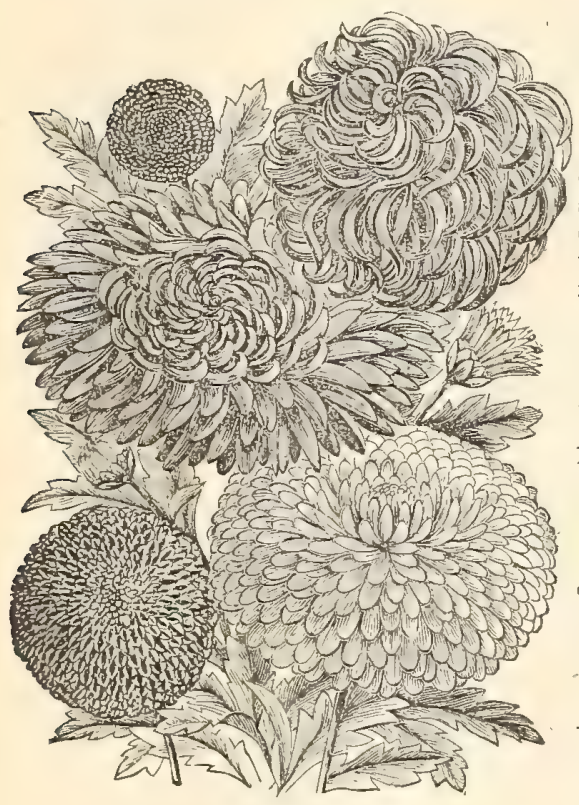

Chrysanithenum.

CHRYSANTHRMUM.

Marguerites.)

This will always be a garden favorite, for in the late autumn, when nearly all out door plants have succumbed to frost, the Chryeanthemum is then in its fullest glory.

\section{SINGLE ANNUAL} VARIETIES.

\section{Burridgeanum - Crim-}

son, white center....... 5

L ord Beaconsfleld -

Crimson maroon-edged,

and striped with golden

rim surrounding \& rich brown eye .............

The Sultan-Rich, vel-

vety crimson maroon,

with golden $\mathrm{r}$ im s u r

rounding a dark brown center

W. E. Giadston $\theta-A$ new and very distinct type, the whole of tine flower being of rich crim-

son, exceedingly brilliant in appearance

Segtum Grandiflorum-Sulphur yellow, 21/ inches across

Mixed colors.

\section{DOUBLE ANNUAL VARIETIES.}

Coronarium-Double white.

Coronarium-Double yellow

Inodorum Plenissimum - A semi-trailing variety, with small double white flowers, fine for vases.

SINGLE PERENNIAL VARIETIES.

Frutescens (Marguerite or Paris Daiey) - The white, star-like flowers of this variety, so popular for decorative purposes, are freely produced under

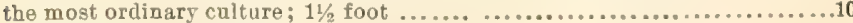

Comtesse de Chambord-Yellow Parie Daiey ......................... 10

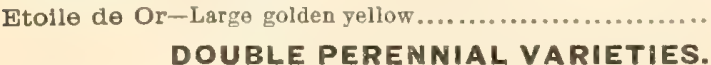

Japonicum fl. pl.-New Japanese variety, eaved from choice flowers,......10 Chinese-Double, finest mixed colors..............................25

\section{CATCHFLY-Silene Armeria.}

Pretty annuale of the easiest culture. The flowers, which are small, white and various shades of red, are produced abundantly. It derives its name from 8 viscid moisture on the stem, which sometimes entraps flies. H. A. Mixed.

\section{CEDRONELLA.}

A desirable plant, with long spikes of flowere, remaining a long time iD bloom. The leaves are fragrant. H.P.

Canna-Purple, 2 feet.

\section{CENTRANTHUS.}

Compact growing plants bearing profusely small bright flowere, borne in slusters on almost transparent etems. H. A.

Mixec-Red and white, $1 \frac{1}{2}$ foot.

\section{CERINTHE-Honey Wort.}

Showy annuals, much resorted to by bees on account of its honey secretions. H. A.

Mixed-Yellow

\section{CHAII 不PEUCE.}

Fine-bone Thistles, curions and ornamental, much need in public gardens. Casabonæ-Glossy, dark green lekves with white nerves and brown spines. H. H. P.

Diacantha-Long, ornamental leares thickly set иith ppines. H. B........ 10 CHOROZEMA.

Cordata-Charming greenhouce shrub, with bright orange-colcred flowers. T. P............................................... no

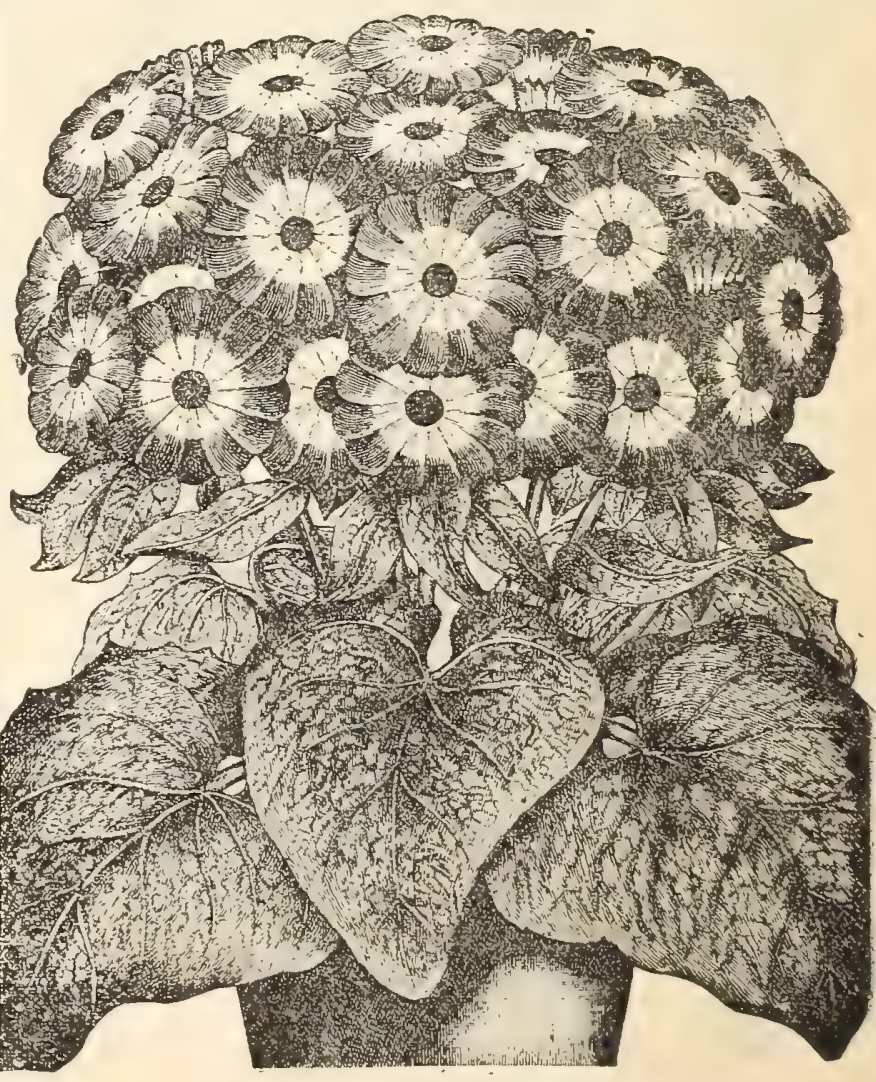

\section{CINERARIA.}

The varieties known as C. Hybrida are well known and exceedingly brilliant. greenhouse plants. C. Marilima is caltivated for its silvery foliage, and esteemed as one of the best plants of that kind for ribbon borders. H. H. P. Hybrida (James' Prize Strain) - The plante are dwarf in habit, Howers very large and beautifully marked, colora brilliant and of fine substance........25 Double Large Flowering Hybrida-Sar et from a choice strain.........50 Maritima-An ornamental foliage plant, with lar ge gilvery leavee........... 5 
 \\ CASTOR OIL BEAN.

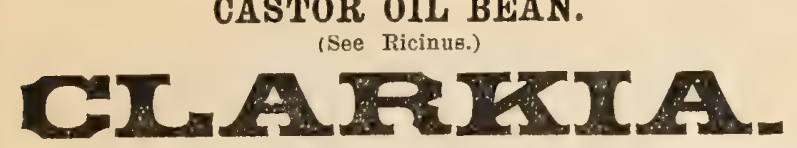

Very desirable plants, extensively used for massing where a brilliant display is wanted. We offer some of the newest and best varieties; $1 \frac{1}{2}$ foot. H. A. Integripetala - Rosy crimeon, large and handeome.................... Integripetala Rose, fl. pl.-Beautifnl double variety

Integripetala Alba-Pure white, very pretty...

ntegripetgla

Limbatta - White margined.

Pulchella-Deep rose

Finest Mixed Single Varieties

Finest Mixed Double Varieties

\section{CLENTATIS.}

A well known hardy climbing plant.

Flammula-White, fragrant, 15 feet.

Jackimani $\nabla$ arieties-

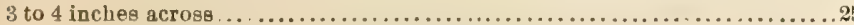

Viticella-White.

\section{CLEOME.}

Half-hard 7 annial, with rose-colored flowers,

Rosea-2 feet.

\section{CLIANTHUS.}

Magnificent plants, which may be fonnd difficult to raise, but which can be successfully grown when sown in open air in May, in a dry, sunny position. H. H. P

Dampleri-A magnificent shrub, flowers in clusters, drooping, pea-shaped, 4 inches in length, of a brilliant scarlet with intense black spots in eenter of each flower......

\section{CLERODENDRON BALFOURII.}

Charming greenhoue climber, producing rich scarlet flowers from snowwhite envelopes. It may also be trained on a trellis as a pot plant, with fine effect. H. H. B.

\section{COB正A.}

One of the finest of our aummer climbers, with fine foliage and Jarge, bellshaped purple flowers. It grows very rapidly, often attaining a height of twenty to thirty feet, and spreading ont correspondingly. In sowing, place the seed edgewise and cover lightly, H. H. P. Scandens-Purple, 20 feet...

\section{COCCINEA.}

Indica-A handsome climber, with brilliant red berries spotted white, foliage

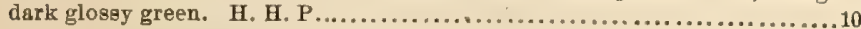

\section{COSMIDIUM.}

Showy annuale, well adapted for groupe and borders. H. A. Engelmanni-Yellow...

\section{COCIRSCOMM.}

(See. Celosia Criatata.)

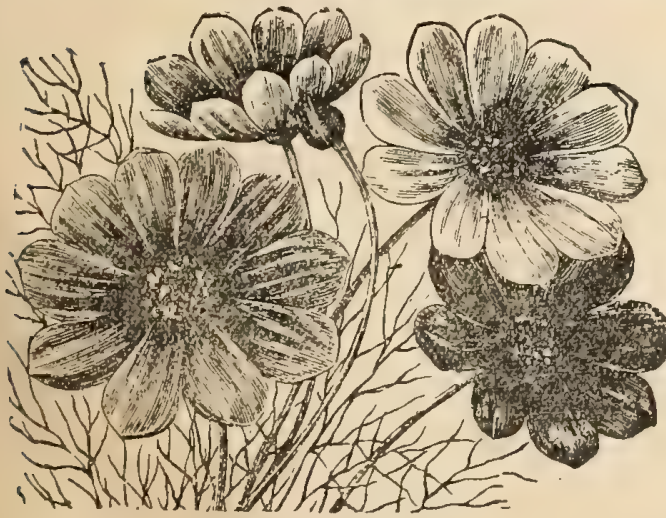

COSMOS.

Free bloomin plants with large single flowers resembling smal single Bahlias. Mixed shades of purple, rose, white, etc.......... 10 Pure White.10 COWSLIP.

In spring this is a very useful plant for borders, but is of little bea uty afte cosmos. warm weather sete in. H. P

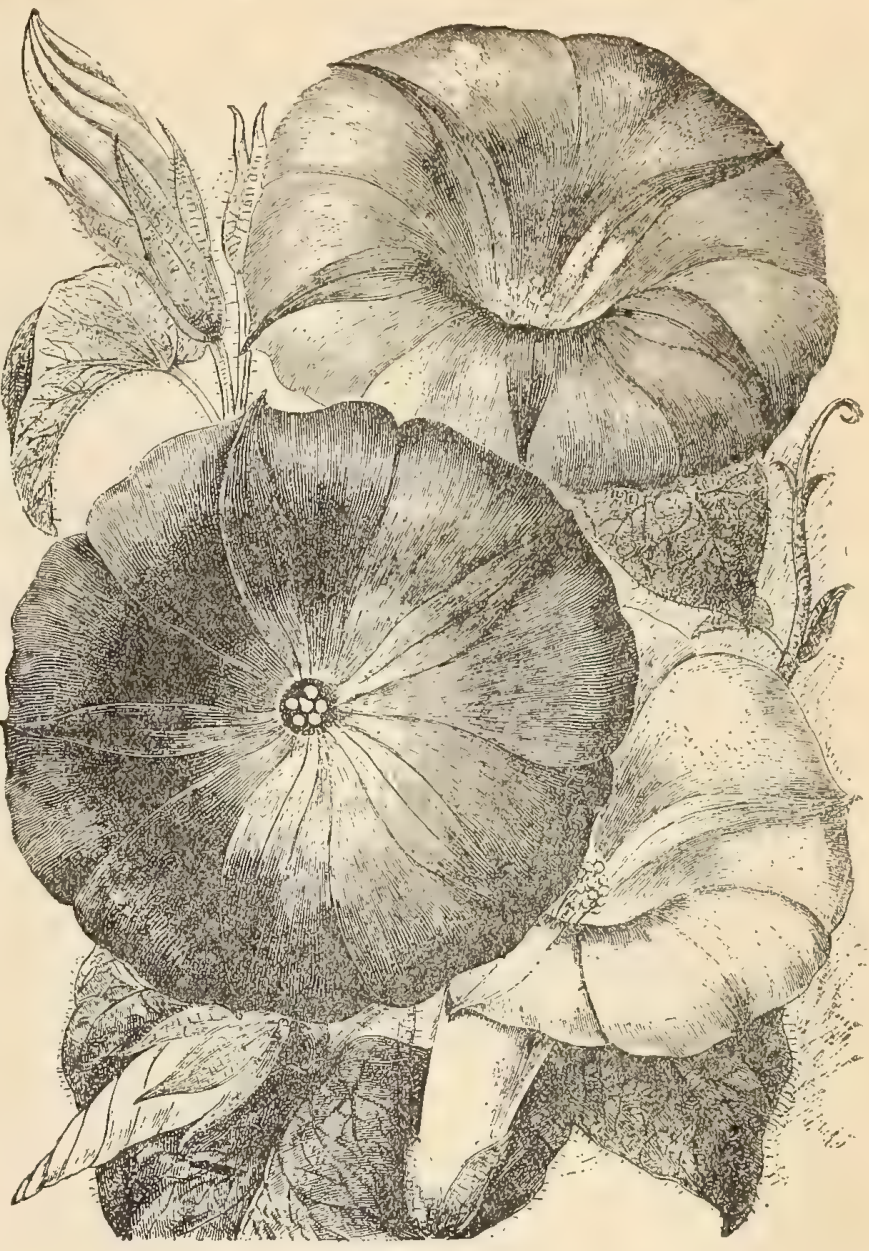

\section{CONVOLVULUS.}

C. Major (Morning Glory) is undoubtedly the most popular annual climber in cultivation. The minor varieties are largely used for bedding and hangince baskete. H. H. A.

Aurea Superbus-Beautiful golden-yellow, 6 feet.................... 10 Major (Morning Glory)-Fine mixed varieties. Per oz., 10 cts.............. Mauritanicus-Hardy trailing plant, about 1 foot high, and produces an abundance of rich, satiny, lavender blossoms. Especially adapted for rockwork or baskets.

Minor Tricolor-Violet, purple and white, 1 foot...................... Minor Uniceulus-An upright variety with compact heads of purplish blue

flowers, 1 foot.

Minor Kermesina Violacea-Crimson violet, very brilliant, 1 foot....... 5

\section{COLEUS.}

Coleus are indispensable wherever colored-leaved plants are desired. The seed we offer may be expected to produce many new, striking varieties, H. H. P. Now Hybrids.

\section{CORDYLINE.}

Australis-Ornamental foliage; greenhouse plant

\section{COLLINSIA.}

Free-blooming annual. The flowerg are in whorles, with several on eacb atem, usually a little over a foot high. H. H. A. Mixed Varieties.

\section{COLLOMIA.}

A useful border plant, and well suited for pot culture. H. A. Mized-Pink and salmon...

CORONILLA. 


\section{CYCLAMEN.}

Valuable pot plants with Orchid-like blossoms of great variety. H. H. P. Albert Victor-The fiowere are an intense brilliant crimson carmine hue.

The foliage differs from the other in the exquisite beauty of its marking8....50

Persicum-Finest mixed, $1 / 2$ foot . . . . . . . . . . . . . . . . . . . . . . . . . . . . . . 15

Persicum Giganteum-Finest mixed; the flowers measure from 2 to $2 \frac{1}{2}$

inches in length. ...

Persicum Giganteum Album-A profuse bloomer, flowers pure white,

plant dwarf and compact, foliage beautiful...........................25

Persicum Giganteum Rubrum - A superb variety, producing very large

flowers of a delicate rose color, changing to bright crimson at the base.......25

Persicum Giganteum Roseum-Similar to the preceding, except that

the flowers are a beautiful rose color.

\section{CUPHEA.}

Commonly called "Lady Cigar Plant." Our variety, however, is a great Emprovement on the old sort. H. H.P.

Ecezlli Grandiflors Superba-Grows 31/2 feet high, and studded in winter with countless red blossoms.

\section{CUCUMBER (Wild).}

(See Echinochystus.)

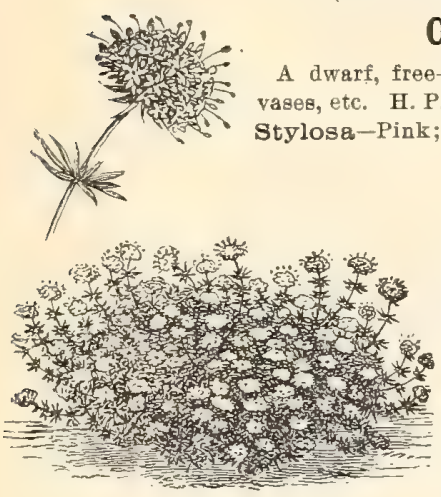

CRUCIANELLA.

tructanella.

-flowering plant, useful for rock-work, from Pereia; 1 foot

\section{CYCLANTHERA.}

A curious climbing plant, bearing oval-shaped fruit which explode日 loudly when ripe; hence its name, H. H. A.

Explodens-10 feet...............

\section{CYPRESS VINE.}

A deservedly popular climber, with pretty star-like flowers and fern-like foliage. Grows to a height of 15 feet. H. H. A.

New Ivy-leaved-d new variety of scarlet Cypress Vine, with Ivy shaped

leaves and slender stems of a violet hue. Flowers scarlet.

Rose.....

Searlet.

White.

Mixed. Per oz, 25 cts.

\section{DATURA.}

Hardy annual, with double flowers, purple, white, yellow, etc. The roots ran be preserved in a cellar like Dahlias. H. A

Double Golden.

White

Finest Mixed-3 feet.

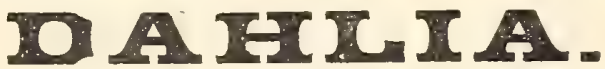

Many of the varieties of the single Dahlia are exceedingly beantiful, and the seed we offer, saved from one of the best collections extant, may be expected to produce many distinct desirable sorts. H. H. P

\section{DOUBLE VARIETIES.}

Extra Choice Double Mixed, from finest named flowers.

Pompone-Finest double mixed; small flowering.

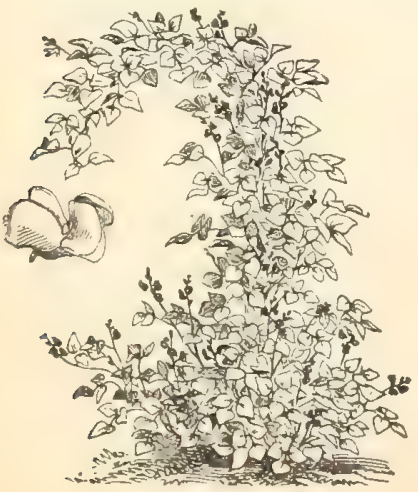

SINGLE VARIETIES.

Very showy and fine for cut flowers; finest mixed.

CACTUS DAHLIA.

Juarezii-Handsome scarlet flowers of curious appearance.

\section{DAISY.}

See Bellis.)

\section{DOLICHOS-Hyacinth} Bean.

Handsome climber with pea-like blosBome. T. A.

Lablab-Purple; beautiful in fall..... 5

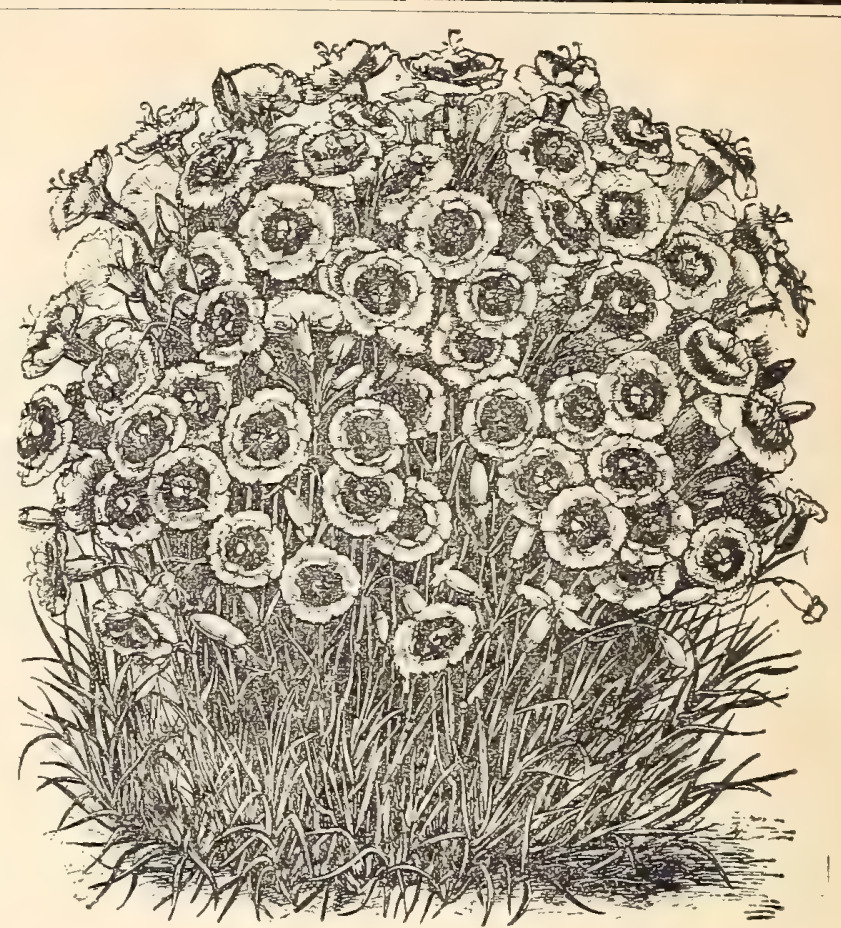

DIANTHUS-THE BRLDE.

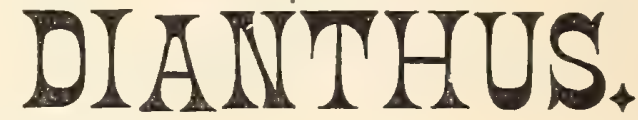

This genus of plants is one of the most brilliant of our garden flowers, and gives universal satisfaction.

SINGLE ANNUAL VARIETIES.

Dienthus, Crimson Bell-Large, rich crimson flowers, finely lacinated.... 5 Eastern Queen-A rine variety, beantifully marbled. Laciniatus-Flowers very large, sometimes 3 inches in dismeter; petals very deeply fringed, and beautifully colored....................... 5 Snow Flake-Finest pare white.................................... 10 The Bride-Flowers large, and beautifully marked dark purple in center with an outer zone of a deeper shade, making a striking contrast to the snowy whiteness of the flower. (See cat)................................ 10

DOUBLE ANNUAL VARIETIES. Chinensis -Best double varieties mixed............................. 5 Diadematus fl. pl.-A striking variety of luxuriant, but dwarf and compact growth. Flowers densely double, comprising all shades of color...........5 Heddewigii-Large flower, 3 inches in diameter, beautiful rich colors, finely marked. Heddewigil Marginatus $f$. pl. (Mourning Pink)-A new variety with flowers of very dark rich colors; all are beantifnlly fringed, and each flower has a white band around the margin. Very fragrant......................10 Imperials $\mathrm{fl}$. pl, -Double imperial pink; mixed....................... 5 Laciniatus fl. pl.-Double fringed .............................. 10 Finest Double-Mixed.

SINGLE PERENNIAL VARIETIES.

Plumarius (Pheasant's Eye)-Mired.............................. 5 Deltoides (Haiden Pink) -Rose colored flowers........................ 5 Plumarius-Mixed harly, festhered garden pink.................... 5 Dentosus-Reddish lilac, with a ring of purple streaks................. 5 DOUBLE PERENNIAL VARIETIES.

Moschatus ff. pl...Garden pink, double, fragrant....................... 10 Plumarius fi. pl.-Double hardy pink, mixed colors.....................10 Scoticus (Paisley Pink)-Mixed..................................25 Gardnerianus fl. pl.-Large fragrant flowers; mixed.....................

\section{DIGITALIS.}

Hsndsome, stately growing plante, with beantifully mottled, thimble-shaped flowers, produced in profueion on a stem usually about 3 feet high. The racemes of flowers are about 2 feet long. H. P.

Fine mixed. 


\section{DELPHINIUM.}

(Perennial Larkspur).

Sow in January, Fobruary or March, in shallow boxes; scatter the seeds thinly an 1 cover lightly. Transplant in similar boxes when the young plants bave three or four leavegs. In April or May plant where they are to flower, in partial shade, H. P,

Forca osum - Large blue and white flowers, 3 feet.................... 5 Nudicaule-Scarlet, Rne.

Grancilflorum-Fine mixed.

Zalil-A handeome yellow variety of branching habit....................10

Le Mastodonte (Giant Bee Larkapur)-Large blue flowers................15

For annual varieties see Larkspur.

\section{DRAC 既A.}

A weli known ornamental foliage plant.

Australis

Conjesta.

Indivisa.

\section{ECHEVERIA.}

A showy, thick-leaved plant, easy of cultivation in the house, or when used for rockerieg, carpet or ribbon beds. H. H. P.

Metalica-Largely used both as a pot-plant for decorative purposes and for beddint...........................................................25 Secunda Glaue a-Used largely as a border plant..

\section{ECHINOCHYSTIS LOBATA-Wild Cucumber.}

A handeome hardy climber, valuable for covering unsightly objects, treestumps, etc. It is a rapid grower, attaining a height of 25 to 30 feet. The beatiful green foliage is dotted over with small white flowere, which develop Into amsll prickly fruits, making an attractive display throughont the entire season. H. A.

\section{ERIANTHUS RAVENN死。}

A hardy ornamental grass, somewhat resembling the Pampas Plume.......10 ERYTHRINA-Coral Tree.

$A$ besuciful shrub, with broad leaves and large spikes of deep scarlet peashaped flowers. Take up in fall before bard frost sets in, cut back, and put away In the cellar over winter. Half-hardy shrub.

Criste Galli- Scarlet.

\section{EUTARTA.}

Zebrins ("iebra Grass)-Ornamental grass, lesves striped across.

EDPHORBIA.

A harily annual, with light green white-margined leaves. H. A. Variegata.

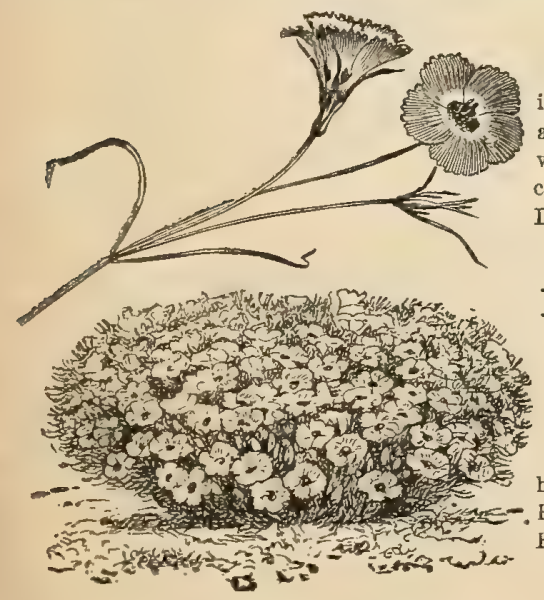

FENZLIA

\section{FENZLIA.}

A splendid, profuse-blooming, neat little plant, graceful and fine for pot culture, and very effective in beds; requires considerable moisture. H. A. Dianthiflora - Rosy lilac,

$1 / 4$ foot.

FORGET-ME-NOT.

(See Myosotí.)

FUCHSIA.

Of this well-known plant we have a choice selection of eeed. Fine mixed, single............25 Fine mixed, double. .........25

\section{FERNS.}

Graceful foliage plants, deserving of more general culture than is given them. No prettier ornament can be imagined than a vase of assorted ferns for the parlor, or what is handsomer in the conservatory than pots or hanging baskets of the various kinds. The hardy sorts are especially effective for outdoor culture in shady places and rock-work.

Terns-Greenhouse varieties, mixed. T. P ......................... 15

Maiden Halr varleties mixed. T. P...................................

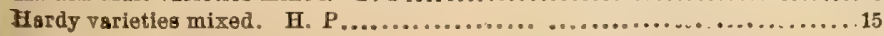

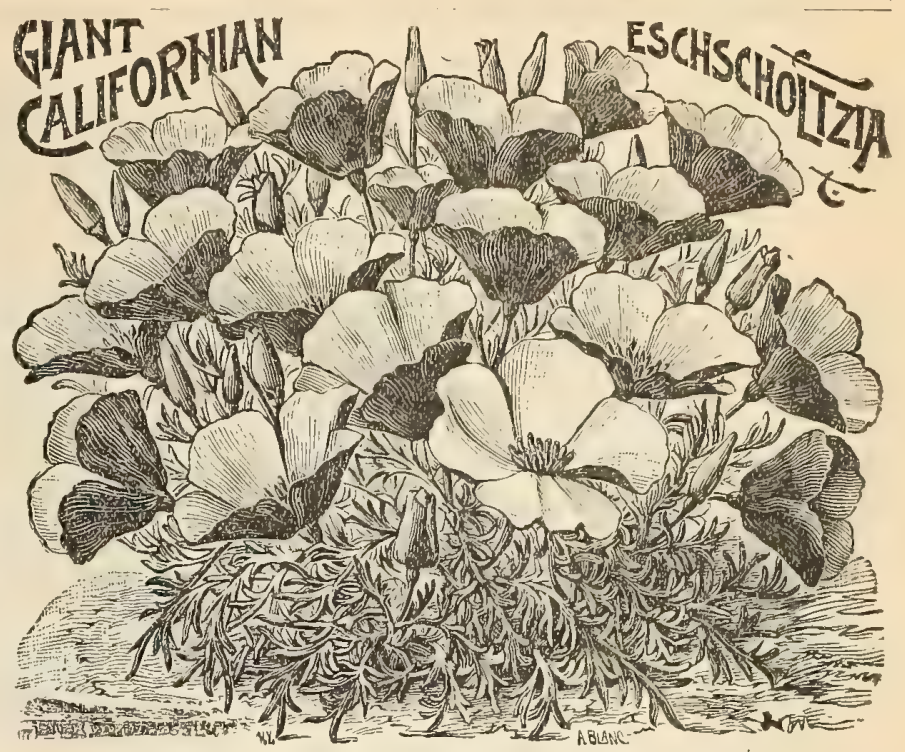

ESCHSCHOLTZIA.

California Poppy.

Exceedingly beautiful free blooming plante. Sow seed in open border in May or June. H. A

\section{GIANT CALIFORNIAN ESCHSCHOLTZIA.}

A new etrain of this well-known annual, produeing much larger flowers than the ordinary variety. The introducer thus describes it: "This new Giant Eschscholtzia is destined to become very popular; the flowers are enormons, measuring 4 to 5 inchee across, almost as large as saucers, on plants grown in congenial situations, and the flowers are borne in such lavish profusion as to fairly hide the plants, although the latter are uenaliy robust and luxurient. This giant strain has been produced by careful selection for a number of years, and contains several beautiful colors in mixture........................... 10

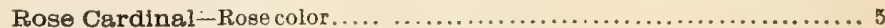
Mandarin-Large bright scarlet, inside rich orange................... Fine Mixed-All colore....................................... 5 Double White DOUBLE VARIETIES.

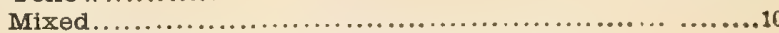
EMMANTHE PENDULIFERA.

Celifornian Golden Bells. (See Novelties)........................25 ERYSIMUM.

Very showy, free flowering handsome hardy annuals, very effective in beds, mixed borders, or ribions; succeed in light, rich soil. Plant and blossom resemble the single Wall-flower, but both flowers and clusters are smaller. Late in the season the Erysimum is very desirable for cutting. H. A.

Arkansanum-Sulphur yellow.................................... Perowskianum-Deep orange flowers ..................................

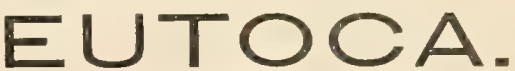

Coarse growing plante with blue flowers, flowering best in light, eandy soll H. A.

Multiflora-Flowers freely .................................. Viscide-Dark blue, pretty ................................ 5

Wrangellans-Lilac............................................

EVERLASTING FLOWERS.

(See Hellchrysum, Xeranthemum, etc,)

GERANIUM.

Sow in boxes in the house or hot-bed.

Singlo-Scarlet..............................................10

$$
\text { -Roвe............................................... . } 10
$$

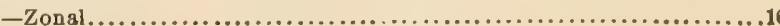

Double-Zonal...............................................

Ornamental-leaved Geraniums:

Gold Bronze....................25 $\left.\right|_{25}$ Gold Tricolor.....................2

Lady Washington Geranium (Pelargonium), choice mixed................ 


\section{0 _urrip Bros.' Hortieultural Guide.——}

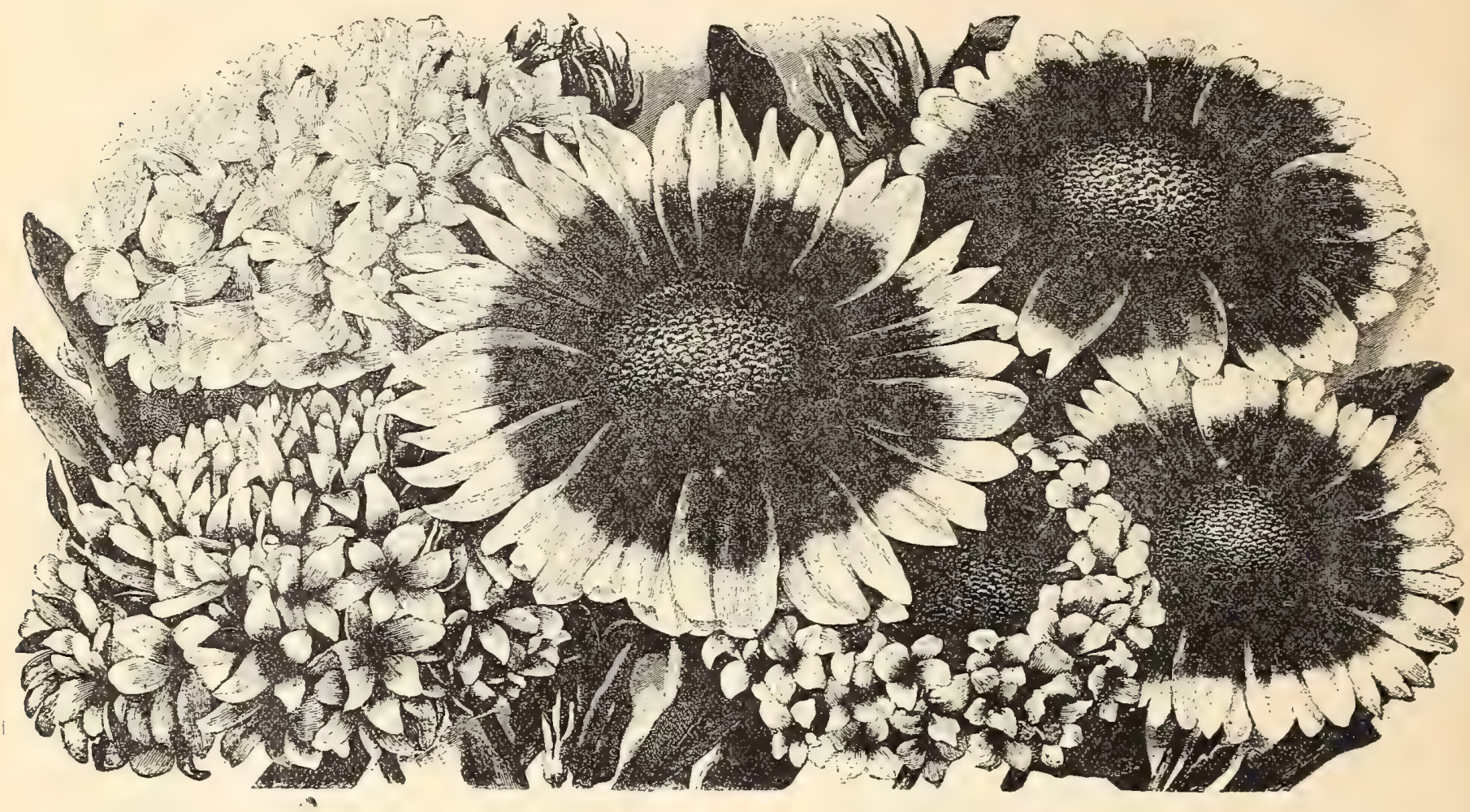

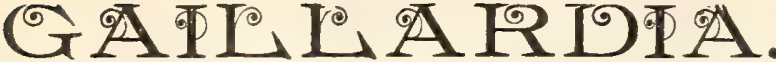

One of the best annuals for bedding, being constant bloomers, and present ing quite a diveraity of color. H. H. A.

Coccinea-Scarlet, 1 foot.

Grandiflora Hybrida-Fine crimeon and yellow, $1 \frac{112}{2}$ foot

Picta Nana-Crimeon and yellow,

Picta Lorenziana-A fine new double variety, with heads 2 incheg in

Fine mired colors. Per oz, 25 cts.

\section{GENTIANA.}

Dwarf hardy perennial, suitable for rock-work, etc. Acaulis-Large blue flowers. H. P....

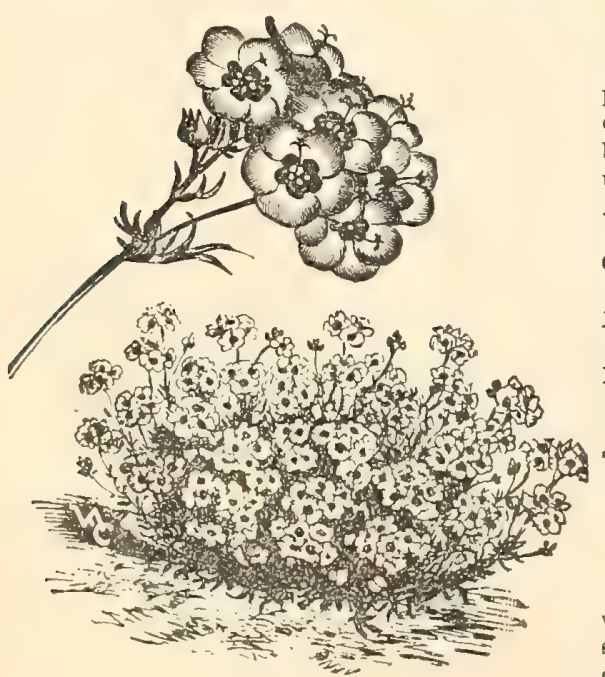

\section{GILIA.}

Pretty free-blooming plante, forming cluster of delicate flowers; will bloom in almost any situation, H. A.

Achilleæfolia - Mix -

Capitata-Major, eky

Nivalis-Dwgrf, snow

white .

Rubra Violacea -

begutiful lilac

flowers ...............

and purple.

\section{GLAUCIOM.}

A pretty border plant, ith sivery leaves, reer. H. P

Corniculatum - Or ange, bell shaped

flowers.............10

\section{GOMPHRENA-Globe Amaranthus.}

Very handeome Everlastings, fine for winter bonquets. Sow seed in hot-bede or boxes in the house, as it sometimes does not germinate well in the open ground. H. H. A

Globosa Alba-Pure white

Globosa Rubra-Dark purplish crimson

Globosa Striata-Pink and white striped Mixed.

\section{GYPSOPHILA.}

Pretty, free-flowering plante. Will do well in any garden soil. The flowers are valuable for bouquet making, either fresh or dried. Muralis-A charmihg little plant, covered with beautiful pink blossome.

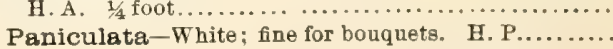

\section{GNAPHALIUM-Edelweiss.}

The true Edelweiss of the Alps. The flowers are of a downy appearance, pure white and star-shaped. They are in great demand in Switzerlund, and often bring a high price as souvenirs. H. P.........................25

\section{GIOXINIA}

Handsome stove and greenhouse plants, producing flowere profueely of great beauty and diversity of color. Extra Choice MixedFrom a splendid collection of drooping and erect varieties. ...

Emperor Frederic-A strikingly handsome variety with erect flowers of an intense crimson scarlet color encircled at the outer edge by a clearly defined pure white band, forming a striking contrast to its

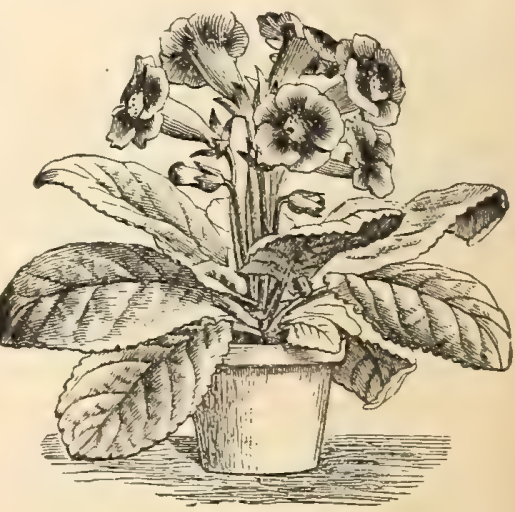

abundant beantiful emerald-green foliase. The flowers are very large, averaging $31 / 2$ inches in diameter, and when well-grown are abundantly $f$ roduced. Packet.... .............................................50 


\section{_- Currie Bros.' Horticultural Guide.——}

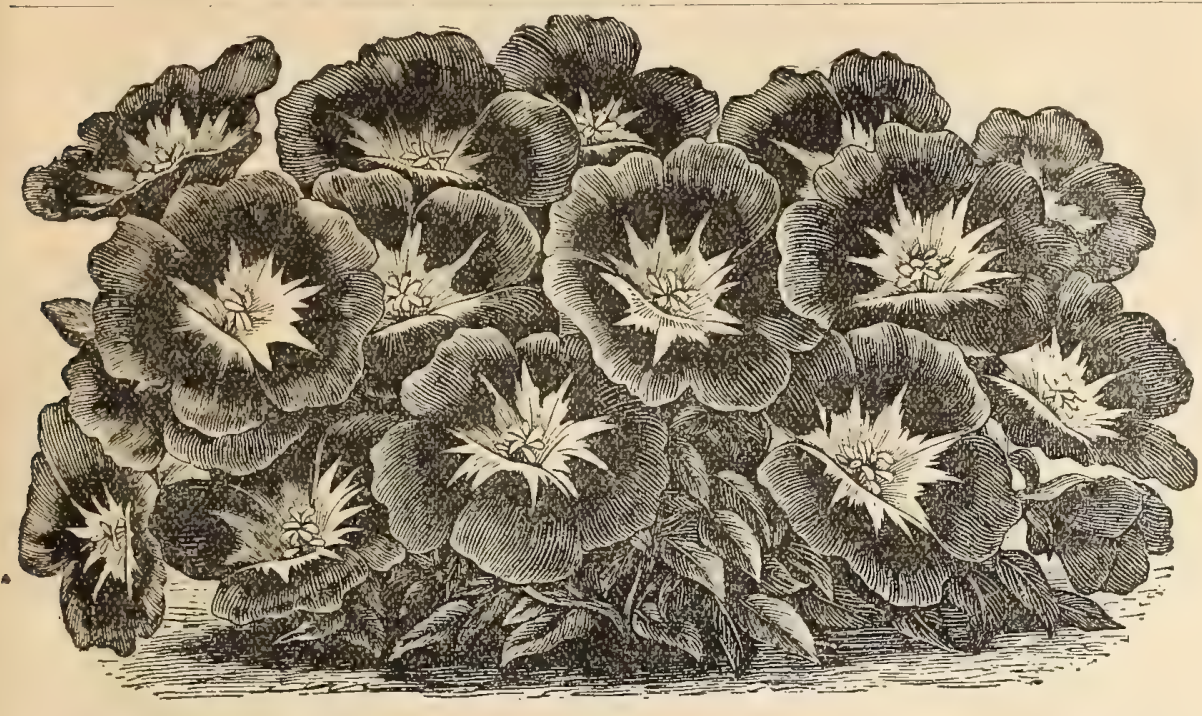

GODETIA.

Free blooming plants, well worthy of attention. H. A.

Duchess of Albany-A new and handsome variety, producing a profusion of large, handsome, satiny white flowers.

Lady Albemarle-A profuse bloomer; bright crimeon.................... Lady Satin Rose-A lovely variety; the flowers are of a deep rose pink, the eurface shining like satin....

Whitneyi-Rich carmine, ehading to light roke; free bloomer... fi. pl. -Double rich variety....

Brilliant-Beautiful carmine.

Fairy Queen-Pure white-bordered rose, spotted carmine.

Bride-White, crimson center

Bijou-Dwarf, white with crimson epots......

Finest Mixed.

\section{GOURDS-0rnamental.}

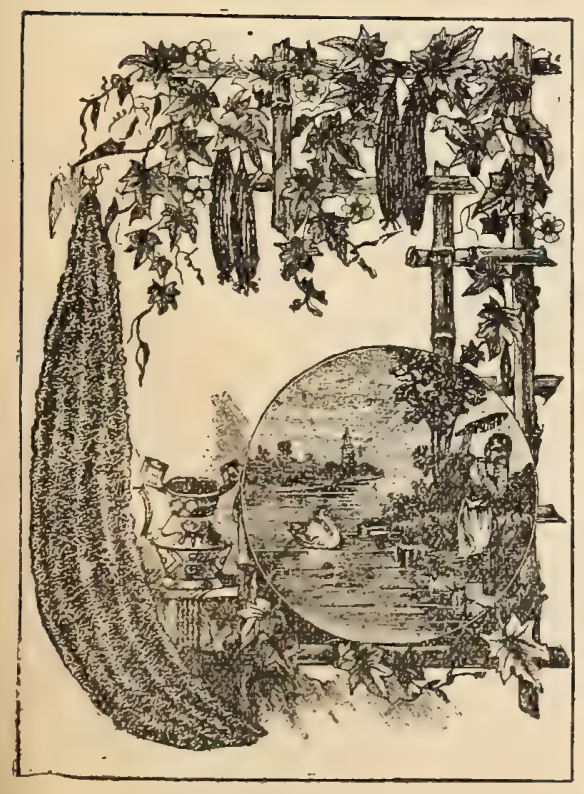

DISH RAG, OR CHINESE LOOFA.

Hercules Club-Lerge, long, chub-shaped.

Siphon...............

Sugar Trough

Turk's Turban
Handsome climbers of rapid growth, producing fruit of peculiar and various forme. T. A.

Dish Rag or Chinese Loofa-An attractive variety, grows rapidly; flowers yellow, developing into large green fruite, the inside of which, when ripe, form a tough, fibrous mase, used as a bathing sponge by many.

Bottle-Shaped.........

Bottle-Shaped Ministure.

Calabasb - The old-

fashioned dipper Gourd 5

Dipressa-Dark green

fruit.....

Dipsecus-s u $1 \mathrm{p}$ h u $\mathrm{r}$ -

yellow; tine.

Echinochystis Lokata (Wild Cncumber)......10

Flexuosus (Snake $\mathrm{Cu}$ cumber). Fruit 3 feet long. berry Gourd) ......... 5
Grossularifolius(Gooep in diameter; color orarge with black center.

GREVILLEA ROBUSTA.

Ornamental plants, suitable for room or conserv atury decoration. Their large, finely divided fernlike foliage gives them a very graceful and elegant appearance. H. H. P.

Per packet.

\section{HELIANTHUS-Sunflower.}

Well-known tall-growing plante, with large and showy flowers. H. A

\section{SINGLE VARIETIES.}

Primrose Colored-A new variety with luxuriant silvery-white foliage; flowers large and of a eoft Primrose yellow

Macrophyllus Giganteus - A large growing variety of pyramidal form.

Mammoth Russian-Single. The largest of all Sunflowers, specimens often measuring 18 inches in diameter .................................

Nanus Folius Variegatus - The foliage variegated, green and white; dwarf................ Oscar Wilde-Flowers measure from 3 to 6 inches in diameter; color orange with black center...... Ministure-Dwarf and branching, producing an abundance of very smail flowers, about 2 inches

\section{DOUBLE VARIETIES.}

Californicus-Extra large, double, 5 feet............................ Globosus Fistulosis-Flowers very large and globular formed, of a bright, rich saffron color; 6 feet.

Oculatis Viridis-Densely double, with green center.

Peruvianus-Double; orange, striped black

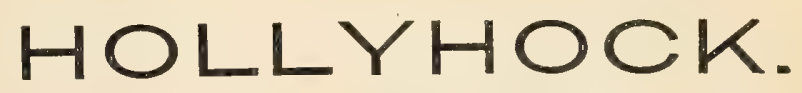

The growing popularity of this grand Hardy Perennial has induced us to make a great effort to procure the choicest strains of eeed? from every eource. The latest addition to our list "Black Prince," is a superb variety and one that is sure to give the greatest eatiefaction.

The seed we offer of this handsome flower has been saved from named varieties of every known shade of color, and can be confidentiy recommended. Seed sown in June or July will produce plants for blooming the next summer. H. P.

\section{NEW BLACK} HOLLYHOCK. Black Prince-(See

Novelties)...

Choice Double Mixed

- Saved from Chater'

prize varietie日.........25

Choice Double :

Pink

Crimson

Yellow

White

Salmon

Red.

Fine Double, Mixed.

BIBISCUS.

Large ornamental play with showy flowers 3 to inches acroes.

Africanus-Cream-yel low, purple center, brown edge. $\boldsymbol{H}, \mathbf{A}$

Coccineus-Scarlet II. H. P
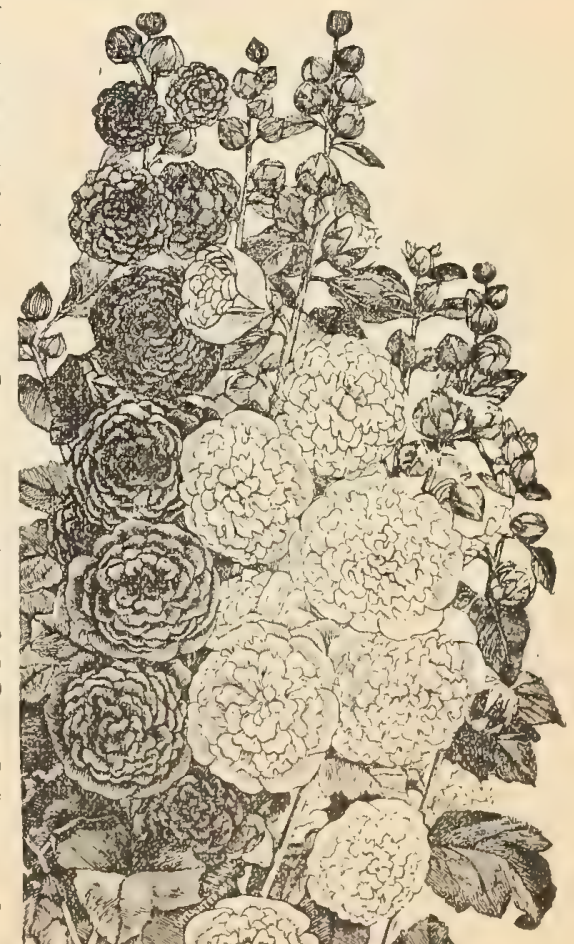

Californicus - $\mathrm{L}$ a r ge

pure white dowers with carmine center. II. P

\section{0}

5

5

5

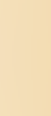

5 


\section{HEDYCHIUM.}

Gardnerianum-For general decorative purposes this has few equals. The foliage resembles very much that of the stronger growing kinds of Cannas, but its striking besuty lies in its blossoms. These are borne in immense clusters on long, stout stems; they, in fact, terminate the regular branches or atems of the plant. In color they are yellow, and are very fragrant. Either for greenhouse or lawn decoration this plant is unsurpassed. It is of very easy culture and readily propagated. Althongh a native of East India, it ig quite at home on our lawns during the summer months. H. H. P. Packet.

\section{HELIOTROPE.}

Deliciously fragrant plants, excellent for pot cnIture. H. H. P. Finest Mired....

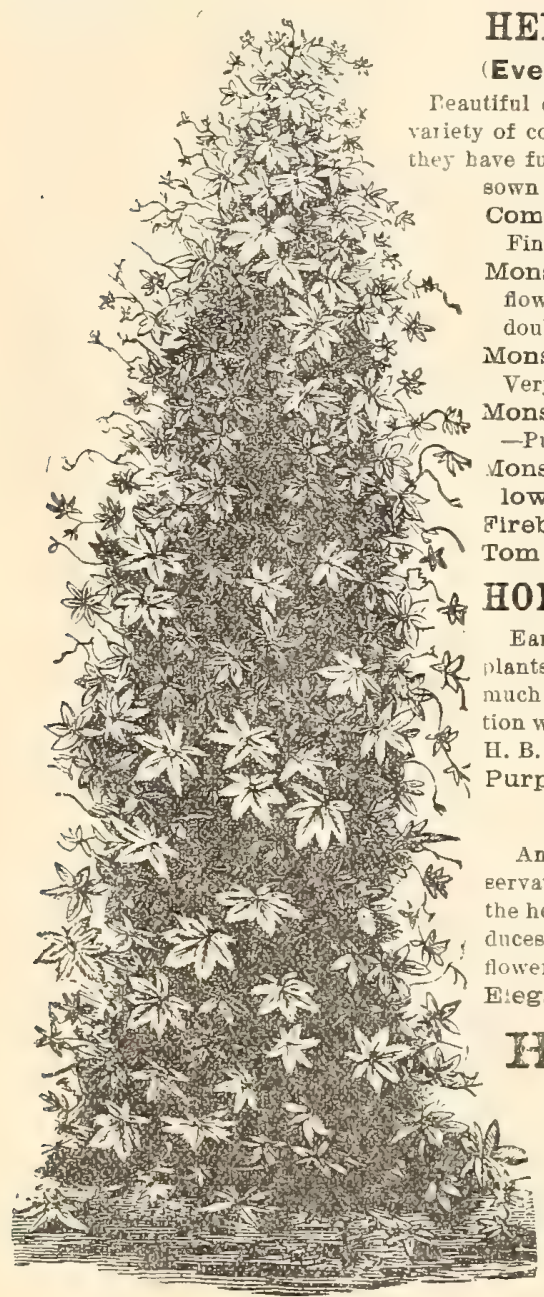

\section{HELICHRYSUM, Everlasting Flower.)}

autiful everlasting flowers of a great color. Cut the flowers before expanded. Seed may be Conpositum MaximumFinest denble mixtd.......... Monstrosum-Large $8 \mathrm{bow} y$ owers; variety of colors double.

Ionstrosum, Double Redy bright.

onstrosum, Double White onstrosum, Double Yellow........... 5 ireball-Very bright crimson, 5 Tom Thumb-Mixed HONESTY-Lunaria. Early summer free-flowering ants, with silvery seed pode, uch admired for winter decoraon with ornamental grasses, etc, Purple-Very showy, 2 feet

\section{HUMEA.}

An atiractive plant for the conrvatory or parlor. It grows to lont 6 or 8 feet, and pro. owers. H. II. B. Elegans.

\section{HUMULUS.}

\section{Japonicus (Japan Hop)} -A rapid growing climber, with luxuriant foliage, excellent for covering verandse, etc. Withotands heat and drought well, and is not troubled with insects. H. A......10

HUYULUS TAPONICUS

\section{HUNNEMANNIA.}

Grows about 2 feet high, with bright yellow Tulip-shaped flowers. Should be treated as an annual in this locality; flowers first season.

Fumariæfolia-Yellow

\section{HYACINTHUS CANDICANS-Cape Hyacinth.}

A Thalf-hardy perennial, requiring a little protection in winter. Its flowers are droopin $q$, pure white, and very fragrant, and are grown on a stem gbout 4 feet in height. H. H. P........................... Bulbs of eame, each.

\section{ICE PLANT.}

A peculiar dwarf trailing plant. The leaves and stems are covered with crystalline globules, giving it, the appearance of being covered with ice. H. H. A. Mesembryanthemum Crystallinum-(Described above)...

\section{IPOHOPSIS.}

Beantiful plants, with long spikes of dazzling orange and scarlet flowers. H. H. $\mathrm{B}$.

Aurantiaca-Orange.

Beyrichii-Scarlet.

Elegans Superba-Orange scarlet.

\section{IPOM झA.}

A beautiful genus of plants, useful for covering trellises, arbors or unsightly objects. H. A.

Bona Nox, Good Night, or Evening Glory-Flowers large, white,..... 5 Coccinea-Sometimes called Star Ipomæa, with small scarlet flowers........ 5 Grandiflora Superba-Fine large flowers, sky-blue, with broad border

Limbata Elegantissima-Large, blossom rich mazarine blue, with a showy white margin...........................................

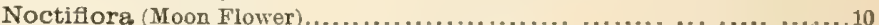
Leari (Blue Dawn Flower)-Splendid bright blue; grows in large clusters... 15 Quamoclit (Cypress Vine) -Scarlet, white, rose; each color................ 5 Quamoclit-Iy leaved, flowers scarlet................

\section{IMPATIENS SULTANA.}

A new perennial Baleam, valuable for summer bedding, and besutiful as a pot plant for the conservatory or parlor. The flowers are single, meseuring fully

1 inch in diameter, and are of rich carmine magenta color. T. P........ . . 15

\section{KALANCHOE CARNEA.}

This strikingly besutiful decorative plant commences to flower at Christmas, and continues in bloom thronghout January and February, and is a most welcome addition to the winter flora, its bright and pleasing color being very attractive during the dull winter months. It attains a height of about 18 inches, and is of good bushy habit. The flowers, which are borne in large clusters, are of wax-like consistency, last a long time in perfection, are of a beautiful delicate pink color, and, in addition, are delicionsly fragrant, which greatly enhances the value of this charming plant. T. P...........20

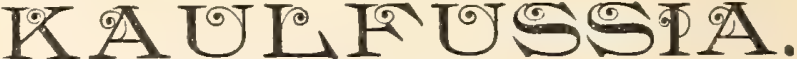

Pretty little free-flowering plants of a neat, compact growth, exceedingly ffective in beds or mixed borders. H. A

Mized Colors.

\section{LAPAGERIA.}

Ros9a-Magnificent greenhouse climber; flowers rose color. T. P.........50

\section{LARKSPUR-Delphinium.}

A beantiful genus. The prevailing color of its flowers is hlue. H. A Ajacis Hyacinthiflorum, Double Dwarf Rocket-Mixed colors....... 5 Candelabrum-Double, mixed, $1 \frac{1}{2}$ foot............................. Double Dwarf Rocket-Fine mixed.............................. 5 Emperor-A profuse bloomer, very donble, mixed colors, 1 foot...............10 Stock-flowered-Tall, mixed, $21 / 2$ feet............................. Double Tall Rocket-Fine mixed. Imported collection of 8 separate Borts... (For hardy perennial varieties see Delphinium.)

\section{LANTANA.}

Very desirable plants for home culture, the varieties of which are almost numberless. All the colors are very pretty. T. P. Hybrida-Mixed.

\section{LATHYRUS-Ever- lasting Pea.}

Showy, free-flowering plants, growing in any common soil. Very ornamental on trellie-work, fences, etc H. P.

Letifollus-Scarlet

Latifollus-White

\section{LAVENDULA - Laven- der.}

Prized for it fragrant violet flowers; succeeds best in a dry, gravelly soil. H. P.

Spica-Lilac, 2 feet.

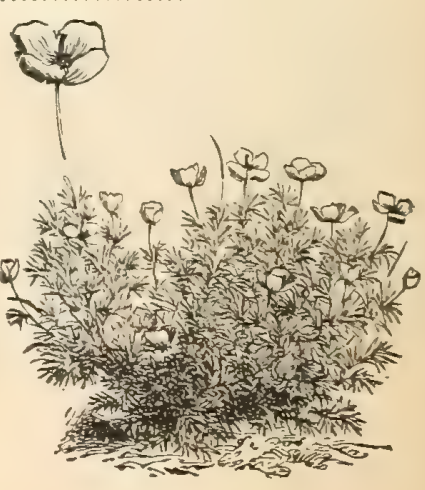

BLNNEMANNIA. 


\section{_ Currie Bros.' Hortieultural Guide.——}

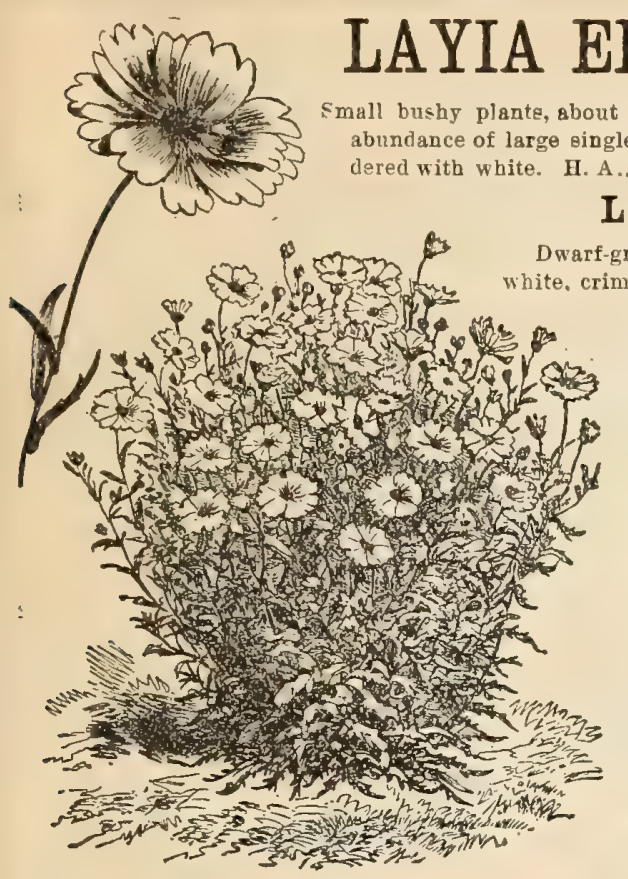

IAYIA FIEGANS.

\section{LOBELIA.}

arf-growing plant with blue, adapted for ribbon borders, and for vases or hanging baskete.

DWARF COM VARIETIES.

For edginge, $\theta$ tc., growing from 4 to 6 inches high.

Carter's Cobalt

Blue-Very fine, dwayf, blue.......10

Crystal Palace Compacta-A beantiful new variety, $1 / 2$ foot.

Gracilis ErectaBlue, dwarf habit.. 5 Prima Donne--In habit it is very compact and dwarf, rich, velvety crimson maroon flower 10

Pumila Magniflca-The finest of all dwarfa, very dark blue, $1 / 4$ foot . ...... 10 Speciosa White Gem-A new pure white variety, fine for bedding, $1 / 2$ foot.10 Emperor William-Beautiful dark blue, dwarf........................10

\section{TRAILING VARIETIES.}

For hanging baskets, vases, etc., 6 to 9 inches high. Gracilis-Light blue.

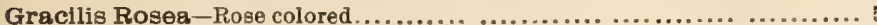

Paxtoniana -White, edged blue .................................. 5

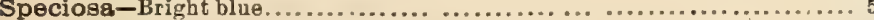

Duplex-A double flowering blne variety.

\section{LOBELIA HARDY VARIETIES.}

Cardinalis, "Cardinal Flower"-Flower spikes 8 inches long, of intense gegrlet... "Cardinal Fiow

Queen Victoris-A new perennial variety, with dark green leaves and brilliant scarlet flowers, 2 feet.......................... 15

\section{LOBELIA LITTORALIS REPENS.}

A pretty trailing plant with an abundance of pure white flowere, succeeded by large green seed pods, which in turn change to bright scarlet. The flowere, green and red fruits, are produced at one time, making a very attractive plant for hanging baskets, etc.

\section{LOPHOSPERMUM.}

Rapid-growing ornamental climbing plante, with large leaves and handsome flowers. H. H. A.

Eendersoni-Rosy carmine........10 | Scandens-Pure violet...........10

\section{LOASA.}

A good climber, flowering profusely all summer. H. H. A

Herbertil-Scarlet, perennial.......10 | Tricolor-Yellowish, annual....10

\section{LUPINUS.}

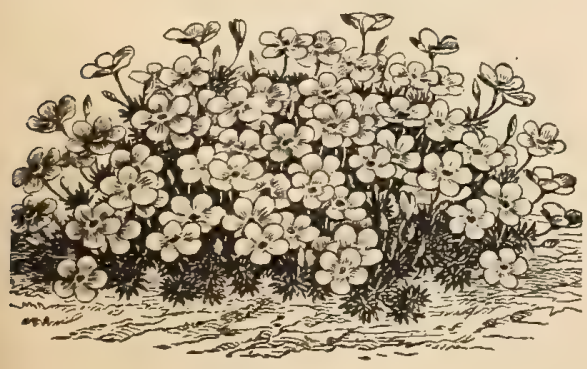

Very desirable plante, bearing long splkes of brilliant colored flowers.

Mixed Annual Varieties........... 5 Mixed Perennial

Varleties ........ 5

IEPTO

\section{SIPHON.}

Pretty little hardy annuals, snitable for borders, H. A.

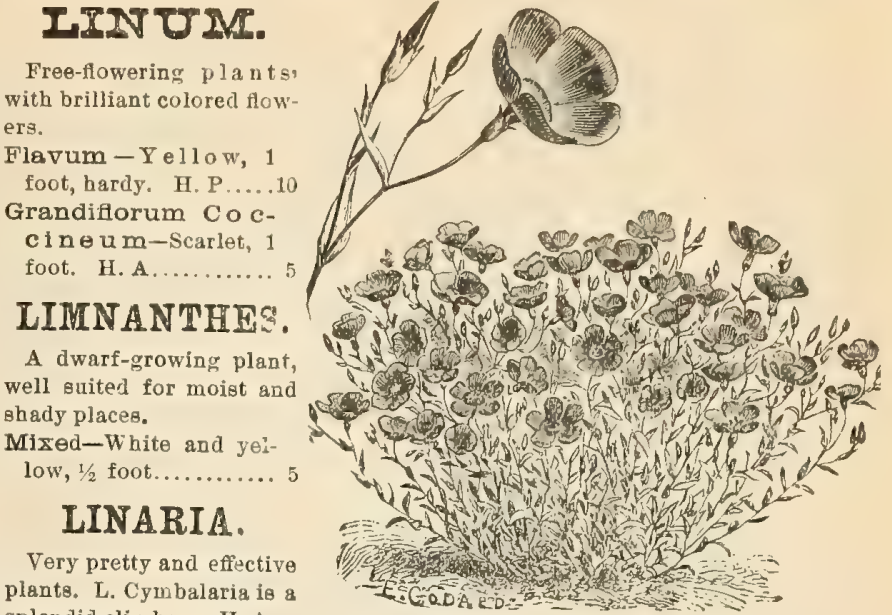

splendid climber. H. A.

worth Ivy)-A rapid growing climber that is very much used for covering

fences or unsightly ohjects

Bipartita-White, $1 / 2$ foot.

Spler dida-Deep purple, $1 / 2$ foot

\section{LYCHNIS.}

A genue of handsome and highly ornamental plants of easy culture, etrikingly effective in mixed flower and shrubbery borders. H. P

Chalcedonica-Scarlet, 2 feet

Haageans-Bright scarlet; splendid

\section{ILARVEL OF PERU-Four 0'clock.}

They are exceedingly fragrant, expanding in the evening and withering next morning. The roots may be preserved through winter like Dahlias. H. A.

Fine Mixed, 2 feet.

\section{MARTYNIA.}

Handsome free-flowering plants, producing a fine effect when planted in the open border; flowers large and handsome, sacceeded by curious, donblehorned fruit. H. H. A. Mixed colore, 1 为 feet.

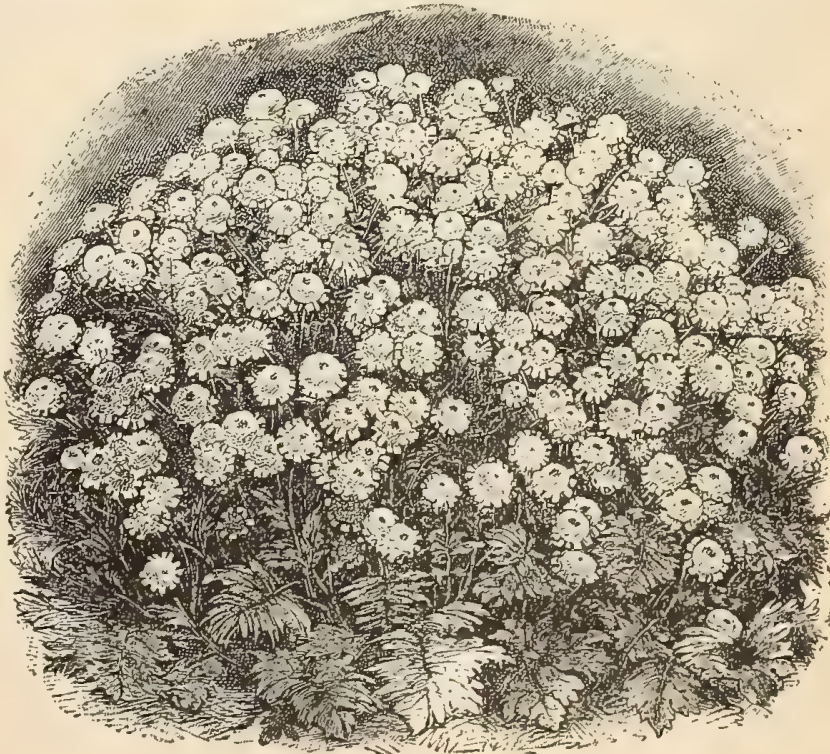

\section{MATRICARIA. \\ Feverfew.)}

Free flowering annuals. Well worthy of extensive cnltivation.

Alba Plena-"Double White Feverfew"-Fine double white flowers, excellent for cutting........................................... 10

Leptosiphon French Hybrids-Mixed colore... 


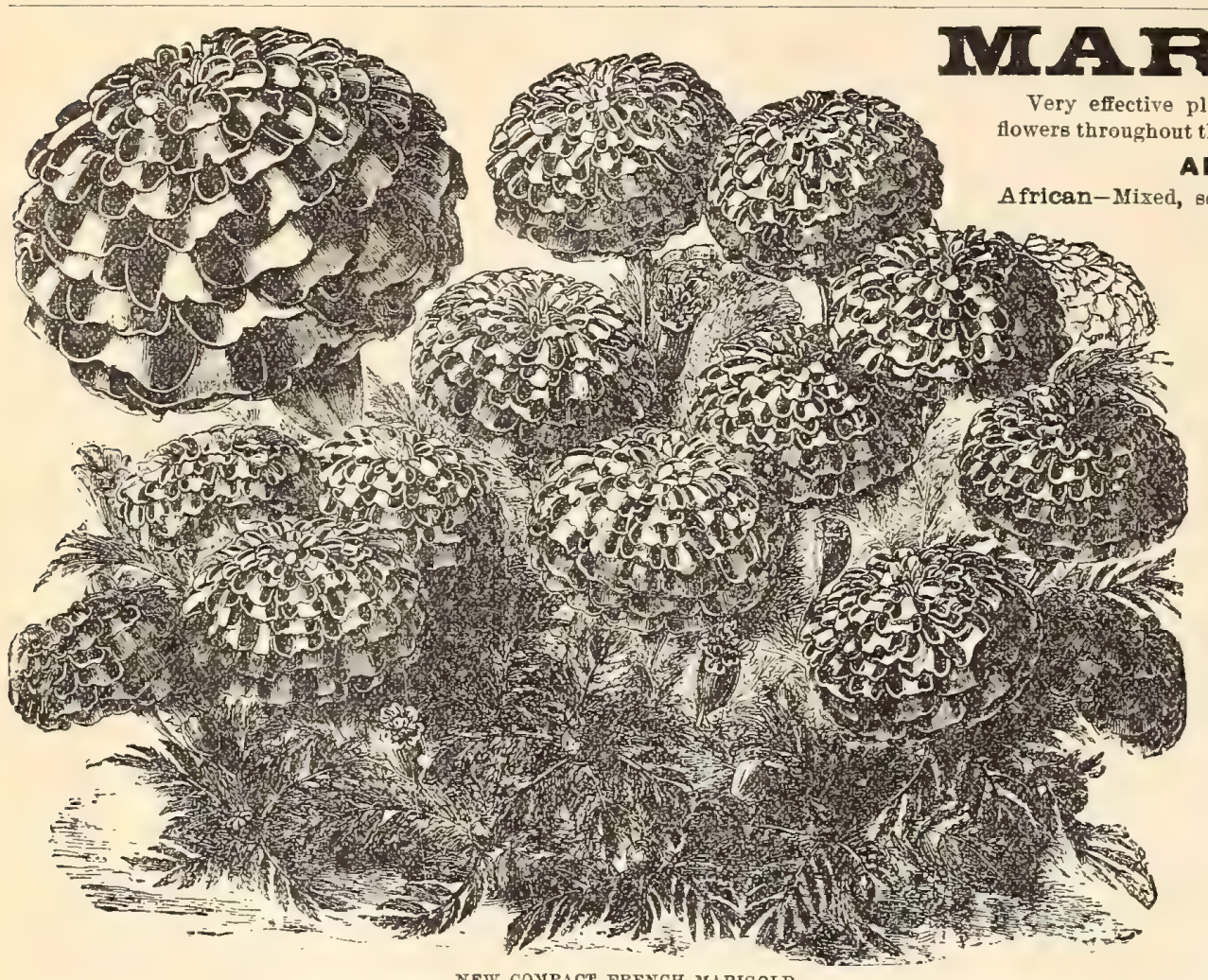

\section{AFRICAN VARIETIES.} beautiful .......................... 5 Orange-Very double................ 5 Lemon ........................... 5

El Dorado-A large flowering variety, producing abundantly flowers varying in color from pale yellow to deep orange... 5 Nugget of Gold-Very double, golden yellow............................10 Fistulosa Lutea-Small finely quilled lemon-colored fiowers....................10
Fistulosa Golden-Small finely quilled golden flowers.........................10

\section{FRENCH VARIETIES.}

Gold Striped-Magnificent stripes of brown on deep gold; very double, 11/2 feet.

Dwarf, Gold Striped -1 foot.......... 5 New, Compact, Gold Striped-A strain of this fine annual bitherto unequaled, each plant forming a handsome bouquet in itself....................... 5 Imported collection of 10 French sorts....50 Imported collection of 6 African'sorts.....30

\section{MORNING GLORY.}

\section{(See Convolvulus.)}

Finest mixed, 20 feet................... 5

\section{MAURANDIA.}

This beautiful summer climber cannot be too highly recommended. Blooms the first season from seed. H. H. P.

Alb8-White, 10 feet.

Barclayana-Rich violet, 10 feet

Scarlet-10 feet.

\section{MALOPE.}

Very pretty plants, of a hranching habit, producing large, showy flowers in great profueion, of the easiest culture. H. A.

Grandiflora Alba-Pure white.

Grandiflora-Large purple flower3...

\section{MESEMBRYANTHEMUN.}

Dwarf-growing plants of gre tt beauty, well suited for hanging baskets and he edgings of flower beds, and for covering rock-work. H. H. P.

Tricolor-Mired colors, $1 / 2$ foot

\section{MIRABILIS.}

A fragrant flowering plant about 2 feat high. Th 3 seed can be sown in the open ground in rows about a foot apart. The flowers are of a variety of brighit colors and grow in clusters" on the summit of the stem. The roots may be preserved'through the winter same as,'Dahlias, H. A.

Longiflora Alba-White, sweet scented flower, 3 inches long

Longiflora Violacea-riolet color.

\section{MIM0SA-(Sensitive Plant).}

A very interesting and curious plant, its leaves closing if touchea or shaken. H. H. A.

Pudica.

\section{MOMORDICA.}

H. A

Balsamina (Baleam Apple)

Charatina (Balsam Pear), 10 feet

Involucrata. Fruits yellow changing to red

\section{MINA LOBATA.}

A handsome climbing plant, bearing continuously clusters of flowers, at tirst bright red, changing through orange yellow to yellowish white. Sow the seed in March in the house, and transplant to open ground in June. T. A..25

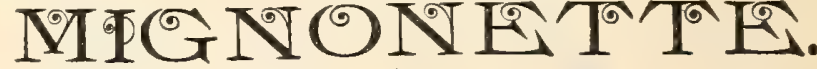

This old favorite is so well known that it is bardly necessary to attempt any description of it. Of late years several new varieties of decided merit have been added to the list. H. A.

Garaway's White-An introduction of very $\mathrm{au}$ perior merit, and well worthy of a place in every garden. Every lover of these eweetscented plants should secure a packet of this variety...

Dwaif Compect - Extensively used for pot culture................... midal-(Reseda Ameliorata) - Quite distinct from the old large flowered variety. Its foliage and flowers are much larger, the plants are of a pyramidal growth and at tain a large size........5

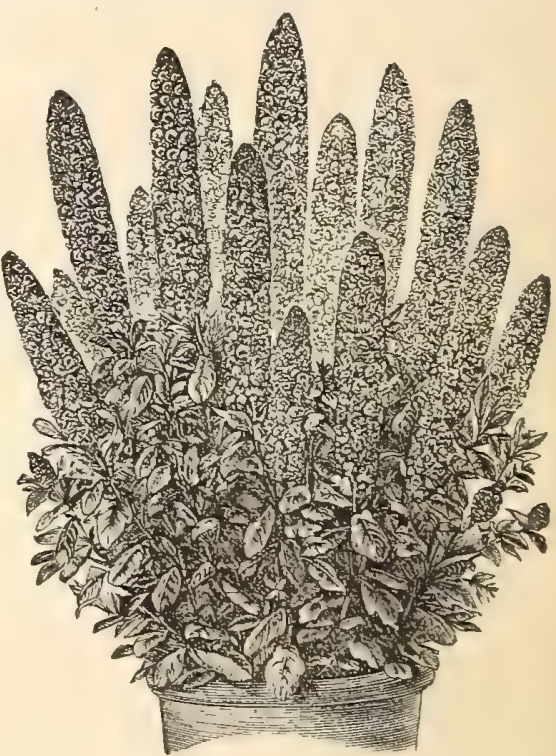

MIGNONETTE-MILEB' SPIRAL.
Diamond-A new pure white variety, very fine .......................10 Bird's Mammoth-A new variety, with very large and deliclously fragrant flowers.................................................... Machet-A variety of dwarf, vigorous growth, with dark-green foliage and deliciously fragrant red flowers; very fine and distinct..................10 Miles' Hybrid Spiral-It is a strong grower and a most abundant bloomer, producing flower spikes from 8 to 14 inches in length; deliciously fragrant...10 Golden Queen-A very pretty and dietinct Mignonette, with thick, compact tufts of a beautiful golden color. Per oz., 50 cts...................... 10 Parsons' White-Flowers nearly white; a desirable variety............. 5 Reseda Odorata-Large flowered variety. Per onnce, $20 \mathrm{cts}$; packet..... 5 The Prize-A most valuable variety. It bears a very close, dense spike, entirely free from straggling blooms; fully twice the ordinary size, and is as

deliciously fragrant as any. Per oz., 50 cts.......................... 10 Victoria-A new dark-red variety, very fine.......................... 10 


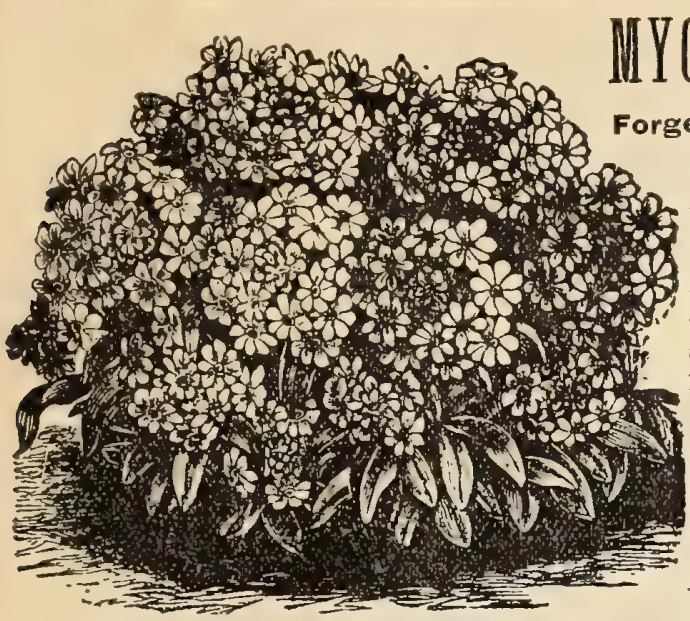

MYดBOTI3--" vICTORIA."
IIYOSOTIS,

Forget-Me-Not.

All the varie ties of this pop ular plant are they succeed well in damp a n d s h a d y places, H. P.

Alpestris Nana Alba -.-Very dwarf wh it $\theta$, $1 / 4$ Azorica-Blue, shaded purple, 1 foot 5

Dissitiflora-Clear blue ; flowers very early, and continues long in bloom, $1 / 2 \mathrm{ft} 10$ Dissitiflora Alba-Pure white flowers, 89 large in size as the original blue variety

Palustris-Blue, $1 / 2$ foot.

Victoria-Forms a round, compact and hushy plant about 6 inches high, completely covered with umbels of beautiful azure-blue flowers. 'See cut;...10 Dwarf Alpine-Dwarf compact-growing varieties; free floweríng; mixed... 10 Semperflorens (Everblooming)-Blooms from early spring to autumn... 10
NIGELLA - (Love in a Mist, or Devil in the Bush).

Compact-growing, free-flowering plants, with curious looking flowers and seed pods. From the extraordinary appearance of the stamens this genus has received its singular names. H. A.

Atropurpurea - Rich purple, $11 \frac{1}{2}$ feet . .......................... 5

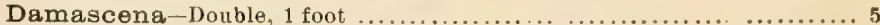

Damascena Nana-Dwarf, varions colors, 6 inches................. 5

Hispanica-Large flowered, very fine, 6 inches...................... 5

\section{NEMESIA.}

Exceedingly pretty compact-growing plante, blooming so freely as to entirely hide the foliage. H. H. A.

Floribunda-White and yellow..5 | Versicolor-Various color......

\section{NASTURTIUII.}

These will always be valuable summer flowering plants. They stand any amount of heat and drought. They flower better, however, in a poor, rocky soll as a rich one has a tendency to make them "run to leaf." H. A.

\section{TALL VARIETIES.}

Edward Otto-Brownish lilac. Per oz., 25 cte... ...

Coccineum Folius Aureus-Flowere bright scarlet, foliage yellow. ....10

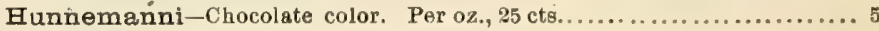

King Theodore-Flowers almost black, foliage bluish-green. Per oz.,35 cts. 5

Regelianum-Violet crimson. Per oz., $25 \mathrm{cts} . . . \ldots \ldots \ldots \ldots \ldots \ldots \ldots . . . . . .5$

Von Moltke-Beautiful rose. Per oz., 25 cts......................... 5

Crimson. Per oz., 25 cts....... 5 Orange. Per oz., 25 cte.........5

Yellow. Per az., 25 cts......... 5 Stræw Color. Per 0z., 25 cts.... 5

Scarlet. Per oz., 25 cts ,....... 5 Mized. Per oz., 15 cts........... 5

\section{MIMULUS-Monkey Flower.}

Beantiful free-blooming plants, suitable for vases or hanging baskete, luxuriating in damp, shady situa tions, H, H, P.

Cupreus-Beautlful orange and crimson..........10 Hybridus-Choice mixed. From the finest sorte, Our strain of this is unexcelled in beanty and color and size of flowers.

Moschatus (Mngk Plant)-Yellow, foliage and flowers having \& delightful musk acent, $1 / 2$ foot. 10 Musk Scented-This very attractive plant growe to the height of from 15 to 18 inches, and pro. duces large yellow flowers, beantifully marked with dark crimson spots. There is a very dark marking in the center of the foliage. It is musk ecented

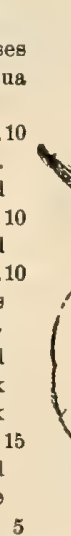
spotted bybrid, rivaling the Calceolaria in the variety of its bright colors....................

\section{MYRSIPHYLLUM-Smilax.}

There is no climbing plant in cultivation that surpasses this in the graceful beauty of its foliage. It can be used either to climb or to droop, as required................10

\section{MUKIA SCABRELA.}

Handsome half-hardy annual climber with pretty yellow flowers, which develop into orange and scarlet fruits.

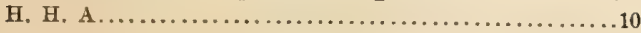

\section{NIEREMBERGIA.}

Charming Ittle plants, flowering profusely during]the whole summer; well adapted for hanging baskets and edgings; for this purpose it cannot be re. commended too highly. H. H. P.

Erutescens-White............. 10 |Gracilis-Slender, lilac, yellow eje.10

\section{ITEIIOPEIIIA.}

Pretty dwarf-growing plants of compact habit, producing an abundance of beatiful flowers throughout the summer months. H. A.

Discoidalis-Black, with white margin, 1 foot..

Insignis-Bright blue, with white center, 1 foot...

Maculata-White, with large purple spote 1 foot.....

Fine Mixed

\section{NOLANA.}

Pretty trailing plants, with Convolvulus-like flowers; fine for hanging basket H. A.

Mixed colorg.

\section{FANCY TALL SORTS.}

\section{(1)} . ,

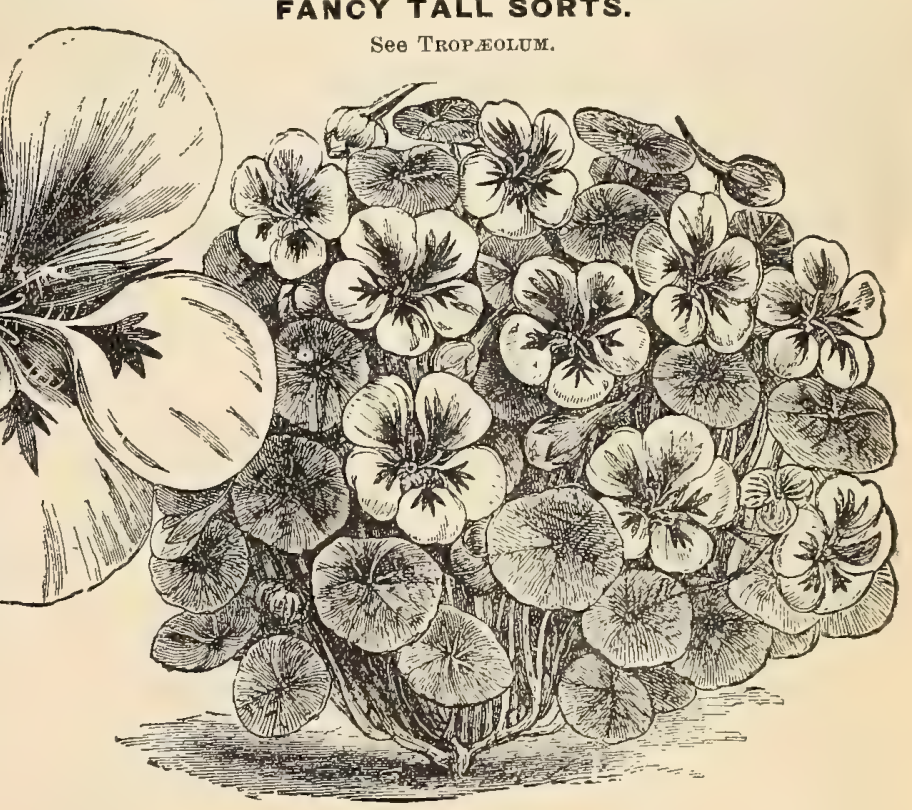

DWARF VARIETIES.

Beauty-Striped red and yellow. Per oz., 25 cts.................... 5 Chameleon-Beautifully marked crimson, yellow and bronze. Per 0z., 25 cte 5 Crimson. Per oz., 25 cts........................................ Crystal Palace Gem-Sulphur spotted. Per oz, 25 cts............... 5 Empress of India-The most brilliant variety in cultivation; very dark fo-

liage and flowers of a rich deep crimson. Per oz., 25 cta................... 5 Golden King -Golden. Per oz., 25 cts ........................... s King of Tom Thumbs-Scarlet. Per oz, $25 \mathrm{cts} . . . \ldots \ldots \ldots \ldots \ldots \ldots . . . . .5$ King Theodore-Black. Per oz., 35 cts............................. s Lady Bird-Golden, with a flame of ruby crimson on each petal. oz., $25 \mathrm{cta}, 5$ Pearl-Cream. Per oz., $25 \mathrm{cts}$.

Rose. Per oz., 25 cts

Ruby King-Ruby. Per oz, 25 cts

Spotted Per oz,

Mixed. Per oz., 20 cts .............................................. For fancy sorts see Tropcolum. 


\section{OXXIISS.}

Very pretty-planta for hanging baskets, vases, rock-work, etc.; flowering freely. H. H. A.

Alba-White.

Rosea-Roee............................................... 5

Tropmoloides-Yellow flowers; foliage brown .........................10

Valdiviana-Fragrant yellow....................................10

\section{PALAFOXIA.}

A fine annual, with rosy crimson flowers and dark center. Set the plants sbout ten inches apart. H. H. A.

Eookerians.

\section{PALAVA.}

A beautiful annual, growing to a height of eighteen inches, and flowering abundantly. Equally valuable for greenhouse or garden. H. H. A Flexuosa-Flowers bright pink; base of sepals almost black............. 5

\section{PERILLA.}

This ornamental plant makea a fine contrast with any of the light or silverlesved plants used for lawn groups or ribbon borders, H. H. A. Lacinlatus-Cat-leaved variety. Nankinensis $-1 \frac{1}{2}$ foot

\section{PHACELIA.}

Pretty annuala, of the easiest culture in the open ground. Most varieties are blue, though вome are white. Very fair as border plants, and good for bonquet making. Good for bee food. H. A.

Congesta-Light blue; per ounce, 20 cents ............... 5

Tenacetifolia Alba-White; per ounce, 20 cente.

\section{PAPAVER}

(See Poppy.)

\section{PHORMIUM-(New Zealand Flax).}

Hsndsome grass-like foliage, suitable for lawn decoration, vages, etc. Folius Variegatis-Variegated foliage.

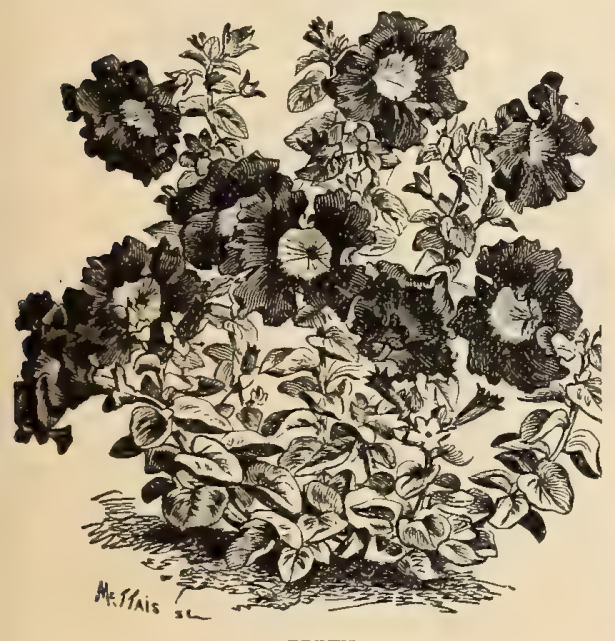

\section{A highly ornamental} and profuse flowering, easily cultivated garden favor ite. The brilliancy and variety of its colors, combined with the duration of its blooming period, render it invaluable for planting out in beds or mixed borders. The seeds of the double Petunia do not possess as much vitality as those of the single, and a good deal of care muet be used to get them to germinate; nor will they $\mathrm{al}^{\mathrm{l}}$ comedonble. H. H. P.

Fine Mixed-Splendid F varieties............... H $\nabla$ brida-Finest striped and blotched varieties, mixed.......10 Grandiflora Steel Blue Veined-A singular and very handeome large fowered Petunia; the flowers have a peculiar color, dark veined.... .......25 Grandiflora Fringed-A new strain with fringed and frilled edgea, very distinct and besutiful, and coming usually true from seed.

Grandiflora Kermesina-Large crimson.......... Grandiflora Marginata-Large flowers, green bordered and veined....... 15 Grandiflora Aurea-Large yellow flowers.............................. Grandiflora Purpurea-Deep violet shade, flowers large................15 Grendiflora Countess of Ellesmere-Rose....................... 5

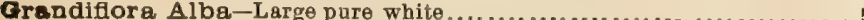
Intus Aurea-Beautful flowers with yellow throat....................... 15

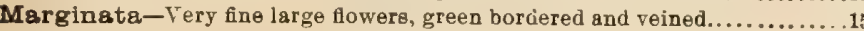
Double Lady of the Lake-A large double pure white variety, very

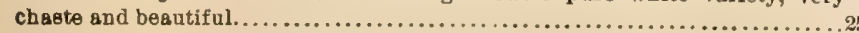

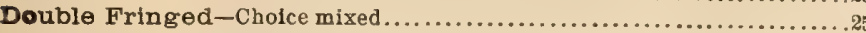
Double Inimitable - Saved from carefully fertilized flowers, and will produce a large percentage of doubles, while such plants as are single are marvels of beauty in colors and markings.

\section{PHLOX DRUMMONDII.}

One of the show iestannuals, valuable for the profusion and duration of its flowers. H. A. Alba-Pure white

Black War rior-Dark purple.

Cardinal-

B rilliant Brarlet

$\mathrm{G} \oplus \mathrm{n}$ er a 1 GrantRich bright purple.

Is abellina -Yellow...

L $e$ o poldii - Splendid deep pink, with white eye..

M armorata-Violet, marb led white...... 5 Oculata Alba-P n re white, crimson eye.... 5

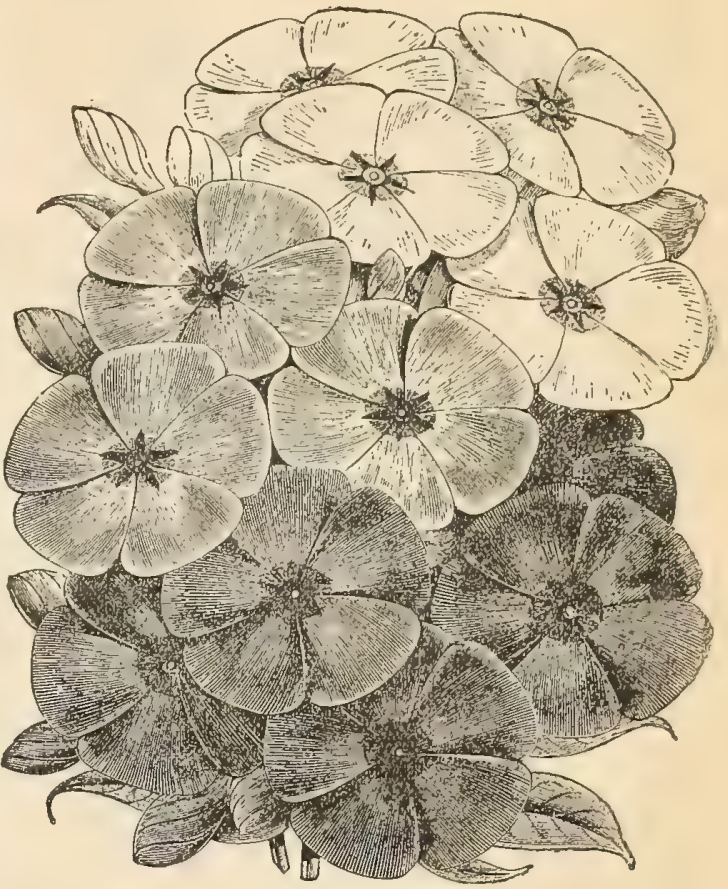

Rose D'A mour-Bright rose

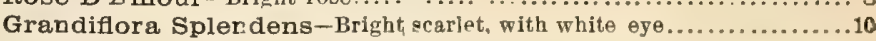
Grandiflora Atropurpurea Alba Oculata-Dark purple, with white

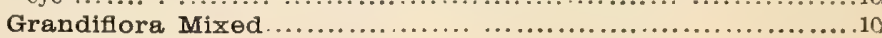
Fine Mixed

NEW DWARF PHLOX.

Small compact plants growing about six inches high, covered with a profu. sion of large flowers. Very fine for pot culture or borders,

Dwarf-White.

Scarlet.

Rose

Punicea Striata-Rich vermilion, striped white.

Finest Mixed

PHLOX CUSPIDATA, STAR OF QUEDLINBURC.

A distinct form of Phlox with sharply toothed and fringed flowers, and the thorn-like middle dente are four or five times longer than in the ordinary varieties; each flower is bordered white, and represents the perfect form of a star. Mixed colors.

\section{PHLOX FIMBRIATA.}

A splendid new strain of Phlox with beantifully fringed flowers, which are produced in great abundance, making a grand display. Mixed colors...

\section{HARDY PERENNIAL PHLOX.}

Favorite hardy berder plants, bearing larg $\rightarrow$ trusses of brilliant colored flowe ere.

Fine mixed varieties.

\section{DOUBLE PHLOX.}

The flowers of the double varieties are much larger than the single, and laet longer in bloom; they are therefore valuable as a cut flower.

Double white. 25 | Double blood red.

Phlox Drummondil-Simplex, (See Novelties)

\section{PENTSTEMON.}

These handsome, herbaceous plants are deservedly growing in favor for bedding purposes. The flowere are bell-shaped, in racemes or spikes, and are constantly produced during the whole seaeon. No one who bas ever seen their beaty will willingly do without them. The seed should be sown in open bor der, covered very lightly, and the plants transplanted when four inches bigh. H. $\mathrm{P}$.

Choice Named Varieties-Seed saved from collection of newest vario-

ties, and cannot fail to give great eatiafaction............................. 

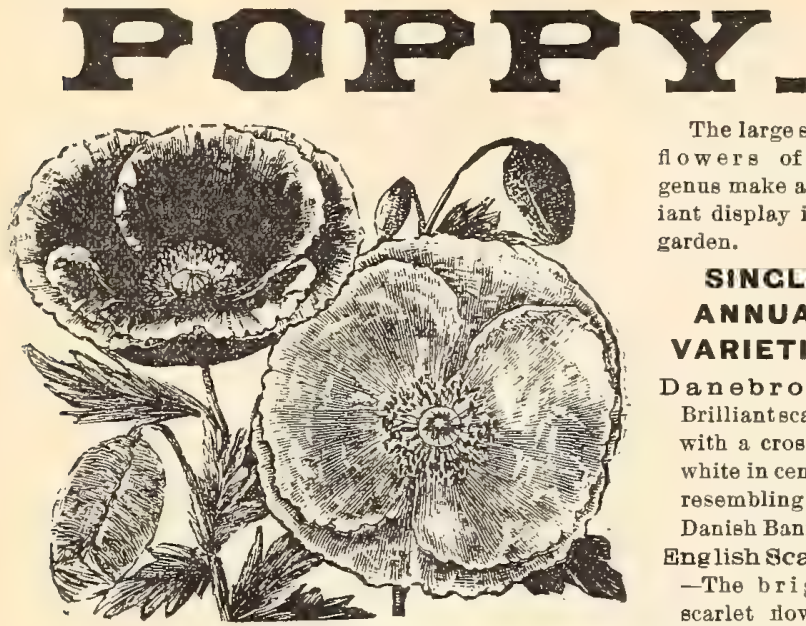

NEIT SHIRLET PUPPIES garden.
The large showy fl owers of this genus make a brilliant display in the

SINGLE

ANNUAL

VARIETIES.

Danebrog

Brilliant scarlet

with a crose of

white in center

resembling the

Danish Banner.

English Scarlet

-The bright

scarlet nowers of this variety

are very effective, 2 feet

Wmbrosum-Rich vermilion, with black spot on each petal.

Peacock Poppy-Large brilliant scarlet and crimson flowers with a black zone near the center, making a strong and beautiful contrast. Flowers about 4 inches in diameter.

Travigatum (Fire Dragon)-A new and very showy Poppy, abont 24 inches high, with fine shaped large flowers 4 inches in diameter, of a brilliant deep acarlet with black spots, surrounded by a white margin at the base of each petal. The two outside petals of the flowers are double the size of the inner ones, so that each couple form a round cup by themeelves. The flowers keep a long time, and the plants are continually in bloom................ Cambricus (Welsh Yellow Poppy, - A beautiful yeīow variety.............. 10 Single Mixed Poppy

\section{NEW SHIRLEY POPPIES.}

Beantiful hardy annual Poppies, producing large single flowers, ranging in color from pure white, various shades of pink, to glowing scarlet. They flowe Freely throughout the season, and maseed have a charming effect. Many of the atowers are veined, atreaked and flaked from the center towards the edges, while others are red, edged with wite.

Mixed colors

\section{TULIP POPPY.}

Papaver Glauclum-(See Novelties)

\section{DOUBLE CARNATION-FLOWERED POPPIES、}

Pure White.

Scarlet

White Tipped Scarlet.......... 5

Rose.

Firy Blush Poppy-New; the petals are splendidly fringed and pure white, except at the tips, where they are distinctly colored with rosy cresm and a light shading of lemon at the base of the center petals.

Poppy, Double French-Ranunculue-flowered, double mixed, 2 feet ........

Poppy, Double New Giant-Preny-flowered, large double flowers.

Now Double Poppy "White Swan"-(For description see Noveltieg), ...25

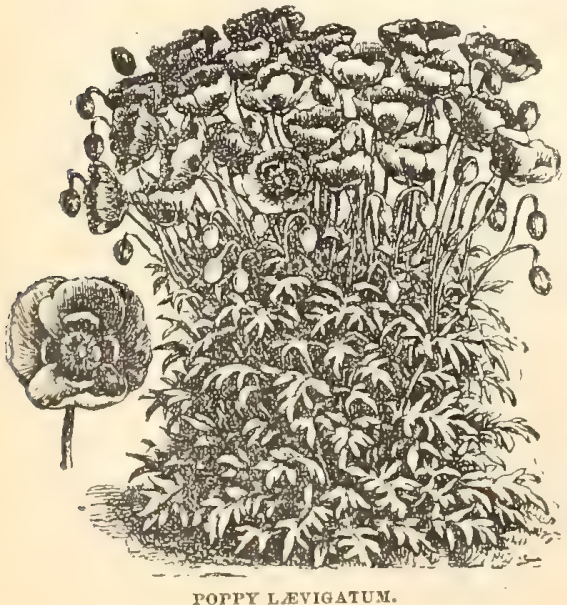

NEW JAPAN POPPY.

The Mikado-A new double variety of great beauty. The petale are beautifully cut and fringed at the edges; color white, fringed brilliant scarlet. H. A.10

\section{Hardy Peren.} nial Varieties.

Bracteatum - Scarlet, 3 feet.

Croceum -- Orange, 1 foot.................. Orientale -- single scarlet, with dark spots.................10

\section{ICELAND POPPIES.}

(Papaver Nudicaule.)

A beautiful and very fragrant class of Poppies, blooming freely throughout the entire season, and while they are perennial will bloom the first year from seed. They are perfectly hardy. The flowers cut are excellent for vases, keeping \& long time in water. H. P.

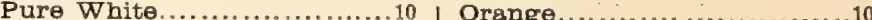

Bright Scarlet................10 Mixed............................10

A very pretty class. ALPINE POPPIES.

Choice mixed colore of yellow, rose, etc ....

\section{GIANT WHITE CALIFORNIAN POPPY.}

(See Romneyi Coulteri.)

POLYANTHUS.

Early spring flowering plants of the Primrose type, suitable either for out door or pot culture. Blooms profusely ; colors: crimson, yellow, maroon, etc., prettily laced and veined. H. $P$

Extra Choice Mixed-Saved from splendid named sorts. (See Novelties).25 Gold Lace-Mixed; flowers beautifully laced golden yellow...............25

\section{PICOTEE,}

Very much like the Carnation; as fine and more delicate in its coloring. Seeds sown in the open ground in May or June will flower well the next season. H. H. P.

Fine Double Mixed. 25

\section{PINK.}

Very closely related to the Picotee and Carnation, but smaller flowers and more hardy. Flowers very beautiful and fragrant. Seed may be sown under glass or in the garden. H. H. P.

Best Double-Mixed colors.

.25

\section{POTENTILLA.}

Beautiful flowering berbaceous plants, continuing a long time in bloom;"fine for lawns or mixed bordere. H. P

Finest Mixed.

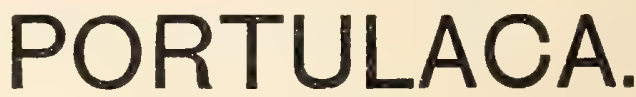

Popular hardy annuals, producing flowers of almost every hue in the greatest profusion; succeed best in warm, sunny places, and will hardly ever suffer for the want of moisture. When other plants are dying for lack of water, this little beauty will continue blooming freely.

\section{SINGLE PORTULACA.}

Alba-Pure white...............5 5 Thellussoni1-Fine crimson..... 5 Aurea-Golden yellow........... 5 5 Splendid Mixed-All colore..... 5 Splendens -A гову purple........ 5

\section{DOUBLE VARIETIES.}

\section{Large Flowering.)}

The flowers of the double varieties make a grand display, remaining open all day in the burning sun.

Carnation, Striped

Orange

Purple.

Rose.

Scarlet

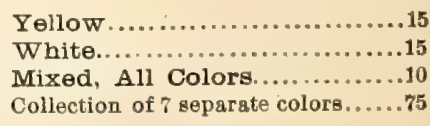

\section{PYRETHRUM-Feverfew.}

Old favorite herbsceous plants very much in use for borders

Parthenifolium Aureum (Golden Feather)--Bright golden foliage; one of the beet bedding plants. H. P................................ 10 Double French Hybrids-Beantiful large flowering hardy plants, bearing their bright-colored double flowers of crimson, pink, rose, white, etc., in

great profuelon throughout the season. H. H. P........................ 10 Roseum-(Pereian insect powder plant)-Rose colored. H. H. P.............10

\section{PRINCE'S FEATHER.}

A showy plant of the Amaranthus family, with erect masses of red flowera.... 5 


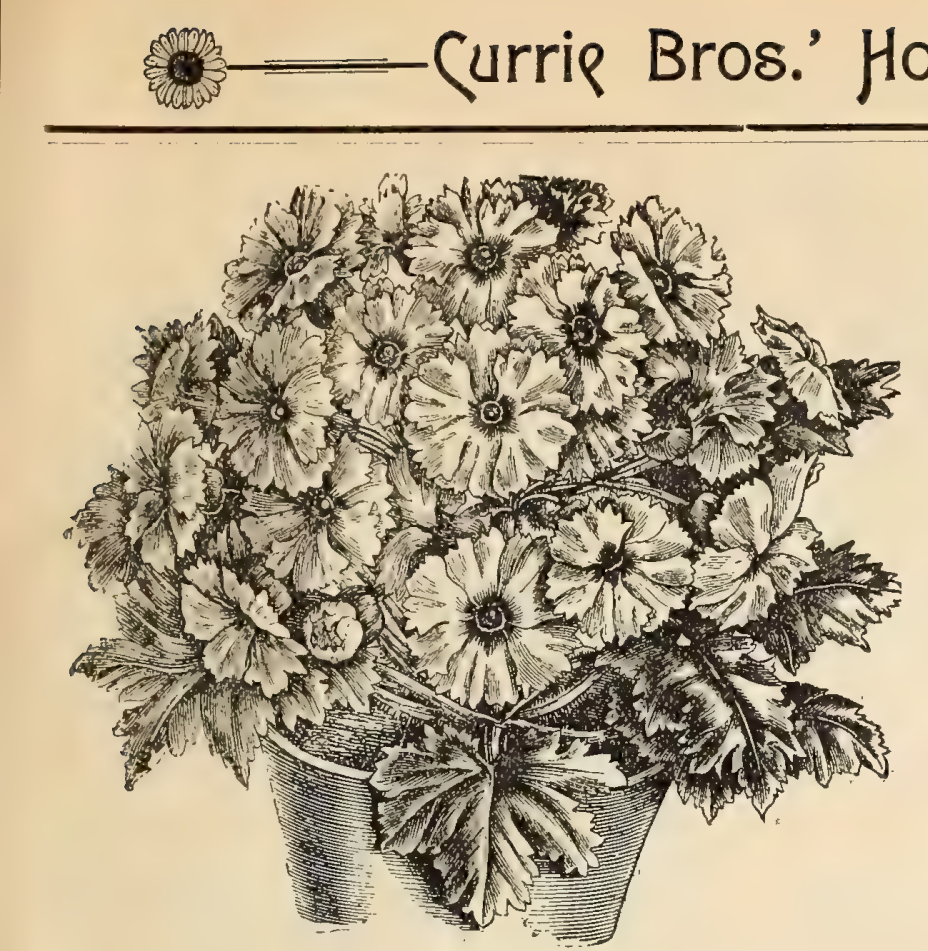

\section{PRIMULA- Chinese Primrose.}

Of this lovely genus of plants we offer seed of the choicest and newest varie ties, all of which are very striking and handsome in appearance. Sow the eeed in February, March or April.

\section{SINGLE LARGE FLOWERING FRINGED VARIETIES.}

Corulea (Blue Primula)-A new variety of Primula of a beautiful blue color. This is a shade in these flowers which has been much sought after, and we are sure will be hailed with delight. The seed we have obtained is from very fine stock and may be relied upon to produce excellent plants....35 Magniflca-Mixed, A great improvement on the old varieties........... 25 Alba Magniflca-A variety of exquieite form and very compact habit. The flowers are pure white, with bright yellow eye, and measure $2 \frac{1}{4}$ inches in diameter.

Chiswick Red-The most brilliant crimson scarlet Primula yet sent out; of robust habit. The foliage is very finely cut and deep green...

Meteor-The plant is of a compact habit of growth, the leaves being deeply cut and of a dark reddish tinge, which'gives the plant a distinct appesrance...25

P.rincess Lou ise - Splendir

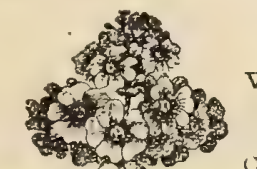
white flowers of great size and substance, and peculiar metallic lustre of surface; very distinct....25 Village Maid-A beautiful variety.

Color, white, striped with car-

mine .....................25 40 Cocinea Magniflca--Rosy scar-
let; clear sulphur eye; free

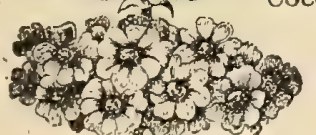
blnomer .....................

Jarminea Alba Punctata - Rich variety carmine, spotted white ..............25

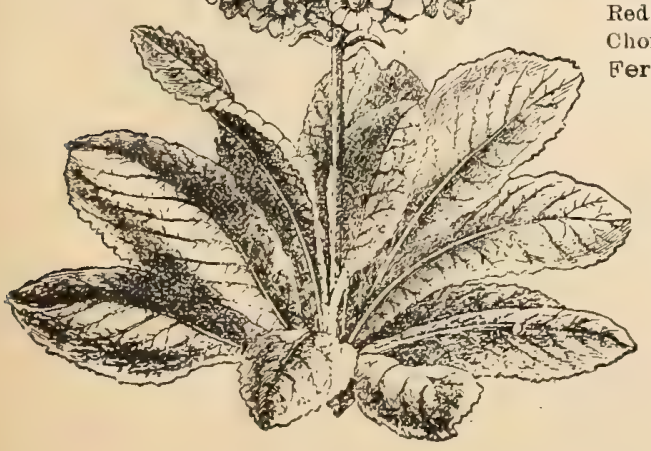

Crimson scarlet........15 Red .................15 Choice mixed.........15 Fern-leaved-Mixed?5 Red...25 White.25

INIMITABLE DOUBLE LARCE FLOWERING FRINCED PRIMULA.

The double varitties produce a large percentage of double flowers, and PRIMULA JAPONICA.

Double Choice Red..............5n

White.........50

\section{PRIMULA.}

PRIMULA Obconica-A very pretty and free-flowering variety extensively grown by florists; flowers pale lilac. 15

\section{HARDY PRIMROSES.}

Pretty spring blooming plante suitable for borders, rock-work, etc.

New Hardy Hybrid Primrose-(See Noveltie日) ...................... . 5 English Primrose (Primula Vulgaria) - The common wild Englieh Prim-

тове. 10

Alpine Primrose-(Primula Rosea)-A handsome new hardy Primrose distinct from any other. It is an abundant bloomer, throwing up numerons flower spikes about 6 inches high, which produce freely large flowers of a bright rosy carmine color with yellow eye.

Japenese Primoroge-(Priutu Japonica)- A beautiful variety. large, borne on stems from 1 to 2 feet high. Mixed shade of pink, white, crimson, maroon, lilac, etc.

Siberian Primrose-(Primula Cortusoides)-A free-flowering sort, of a beautiful rose color. For other varieties, see Auricula, Cowslip and Polyanthus.

\section{RHODANTHE.}

A well-known "Everlasting," valuable for winter bouquets. H. H. A. Albs-Pure eilver white; very beautiful...

Maculata-Bright rosy crimson with yellow disc..

\section{ROSE.}

Saved from choice varieties; will bloom the second year.

French Hybrids-Finest mized.

Tea Scented-Finest mixed.

\section{ROMNEYI COULTERI.}

Giant White Californi-

an Poppy - A peren-

nial of rare merit, resem-

bling large single wbite

Pæonies in its flower and

foliage. The flowers are

very large, messuring 4 to 5 inches in diameter pure white with a bunch of yellow stamens. The texture of the petals is very delicate, almoet transpárent, and retaining the crumpled state (common to most Poppies in the nearly open state) while the flower laste. It is an exceedingly attracive plant and continues in bloom throughout the entire

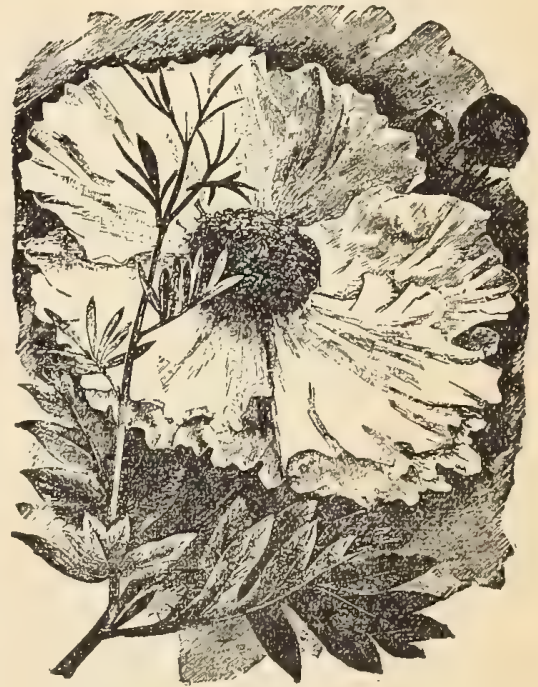
season. The flowers are also valuable cut for vases, keeping well in water, and have a peculiarly delicate Primrose-like perfume. The plants grow to a height of 6 to 8 feet, and while it is not hardy in this latitude, it may be kept over winter in a cold house or cellar.................................... . . . .

\section{SALVIA.}

Handsome plants, with long spikes of flowers, scarlet, blue, etc., which continue in bloom until late in the fall. Sow seeds in April. H. H. P.

Splendens-Vivid scarlet; 3 feet....

Patens-Flowers of a delightful blue................................ 15

Coccinea Lactea-Pure white........................................ 10

\section{SANVITALIA.}

Very pretty dwarf-growing and free-blooming plants. H. A

Procumbens, fl. pl.--Double bright golden yellow flowers produced in great abundance; $1 / 2$ foot.

\section{SAPONARIA.}

Compact growing plants, froducing beautiful star-l1ke flowero freely all summer. Good for bedding. H. A.

Calabrica-Pink................5/ Celabrica Alba-White........5 


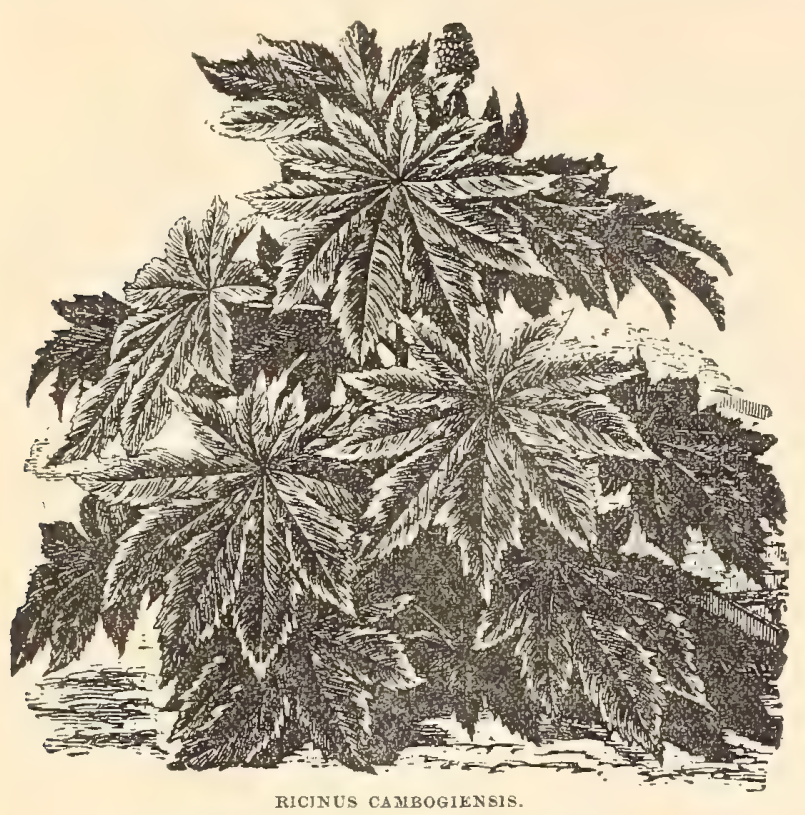

RICINUS-Castor Oil Bean.

Tall-growing ornamental foliage plants of tropical orjgin. H. H. A. Africanus Hybridus-Fine, stalk and fruit rose, 6 feet

Borboniensis Arboreus-Very large and handsome foliage; 15 feet. .

Duchess of Edinburgh-Large and very fine; 10 feet. .

Gigenteus-Leaves of immense size, 12 feet.

Gibsonii-Dark red foliage; 8 feet.

Macrocarpus-Whitish, beautiful; 6 feet.

Obermanii (Sanguinens)-Red fruit; splendid ornamentrl plant; 8 feet.

Purpureus-Purple, magnificent; 6 feet.

Sanguineus-Dark red stalks, scarlet fruit; very fine; 5 feet.

Major-Palma Christi.

Cambogiensis - The leaves are large palm-shaped and of a bronze red color, with red veins. The stems of the leaves are reddish brown, and the main atem of the plant is black, making a beautiful ornament for the lawn. (See cat)

Roseus-Dwarf, buehy habit, with superb rose colored fruit.

Tricolor-Three-colored, very beautiful; " 7 feet.

Fine Mixed.

\section{ROCKET-Hesperis.}

Very fragrant spring flowering y lant 3 of the easiest culture, H. P. Sweet Purple................. 5/ Sweet White.....

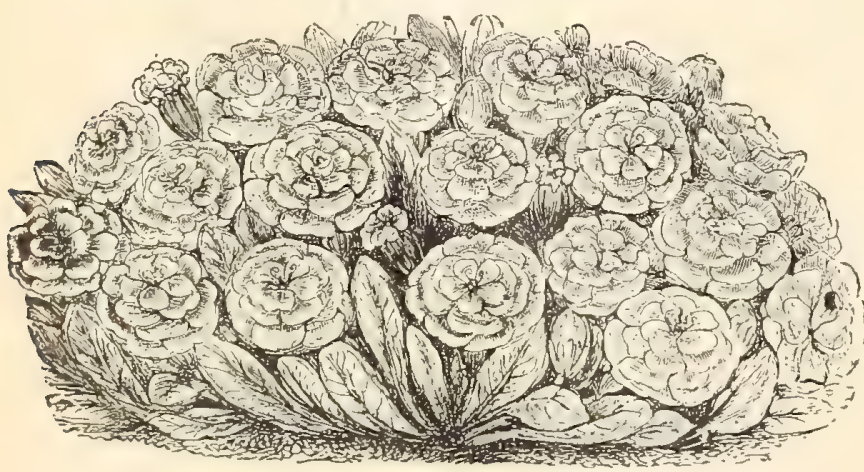

\section{SILENE or CATCHFLY.}

Besutiful free-flowering plants, very attractive for rock-work, etc. H. A. Pendula Compr.cta, "Snow King"-Pure white...

Pendula Compacta-Mixed, all colors.

\section{SCHIZOPETALON.}

Walkerií-Is an interesting little plant with fringed flowere, and valuable for its fragrance. H, A.

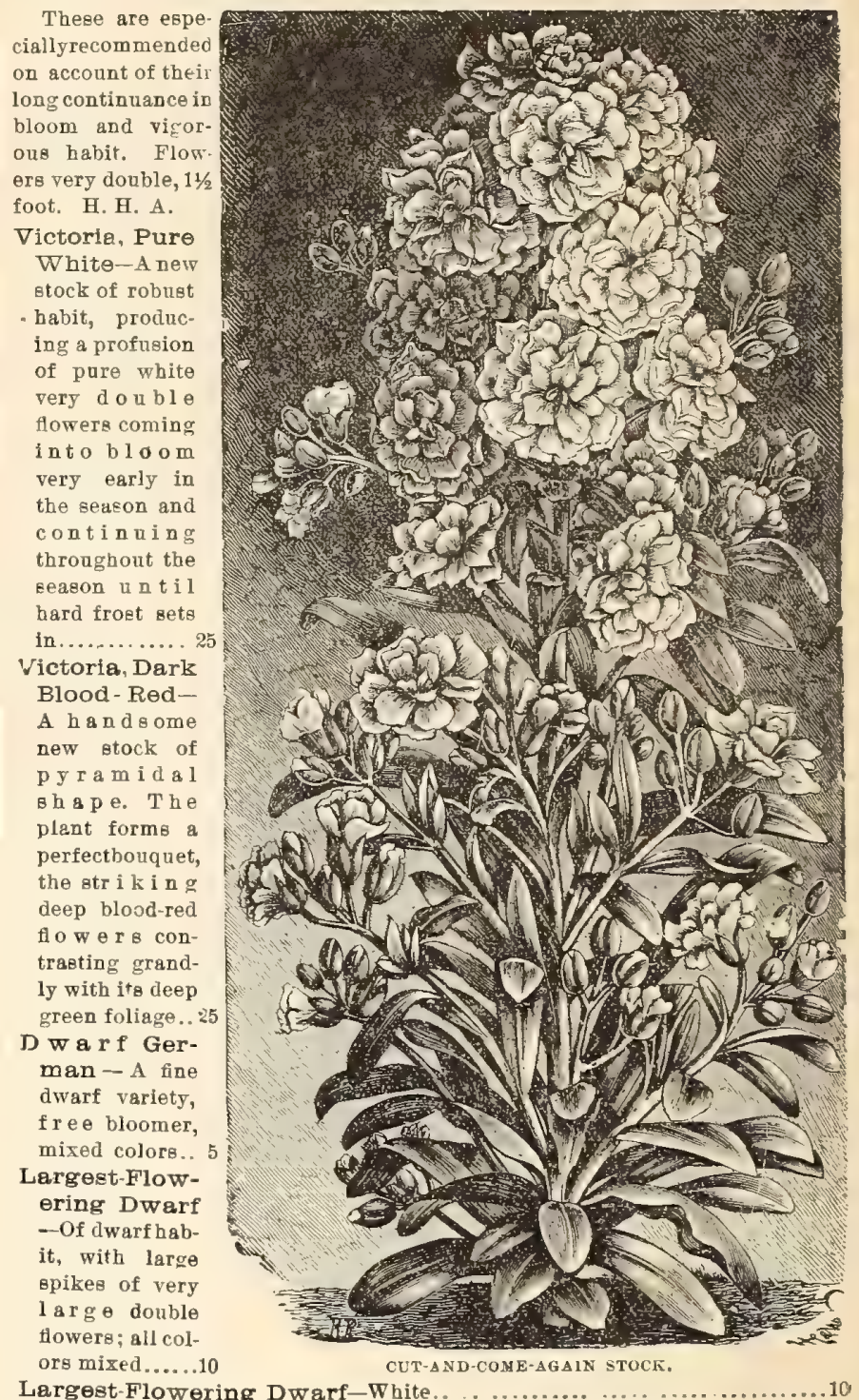
Largest-Flowering Dwarf-White.
Blood red.......... 10 Light blue. $10 \mid$ Rose. blue.

10 i Chamoise. 10 Large-Flowering Dwarf Pyramidal-of pyramidal habit, with long Large-Flowering Dwarf Pyramidal-Sky blue, excellent color....... 10 Giant-Extra fine mixed............................ 10 Collection of 12 choice varieties................................\$1.0

New Giant Perfection-Pyramidal in shape, producing long spikes and double flowers, much larger and finer than the ordinary Ten Week Stock;

New Giant Perfection-Pure white; a large double-flowered variety...... 10 New Giant Perfection-Pure white; a large double-flowered variety..... 65 Wallflower-leaved-Smooth, dark, shining leaves like the $\mathbf{W}$ allitower: Wallflower-leaved-White, grown largely by florists for cut flowers....... 10

\section{CUT-AND-COME-AGAIN STOCK.}

This is a valuable ftock for cutting, branching out as fast as cut, and every shoot bears a cluster of tlowers which are finely shaped, pure white and very fragrant. (See cut.)

\section{STOCKS-Internediate.}

Valuable on account of their flowering late in autumn, or as pot plants for early spring blooming, for which purpose the seeds ohould be sown in July or August.

Early Autumn Flowering-Commences flowering in the autumn, and if removed to the house will bloom during the winter; mixed colore. H. H. A.10 Emperor-Finest mixed, H. H. P...............................

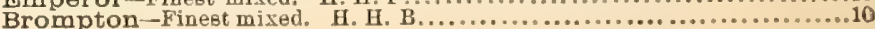




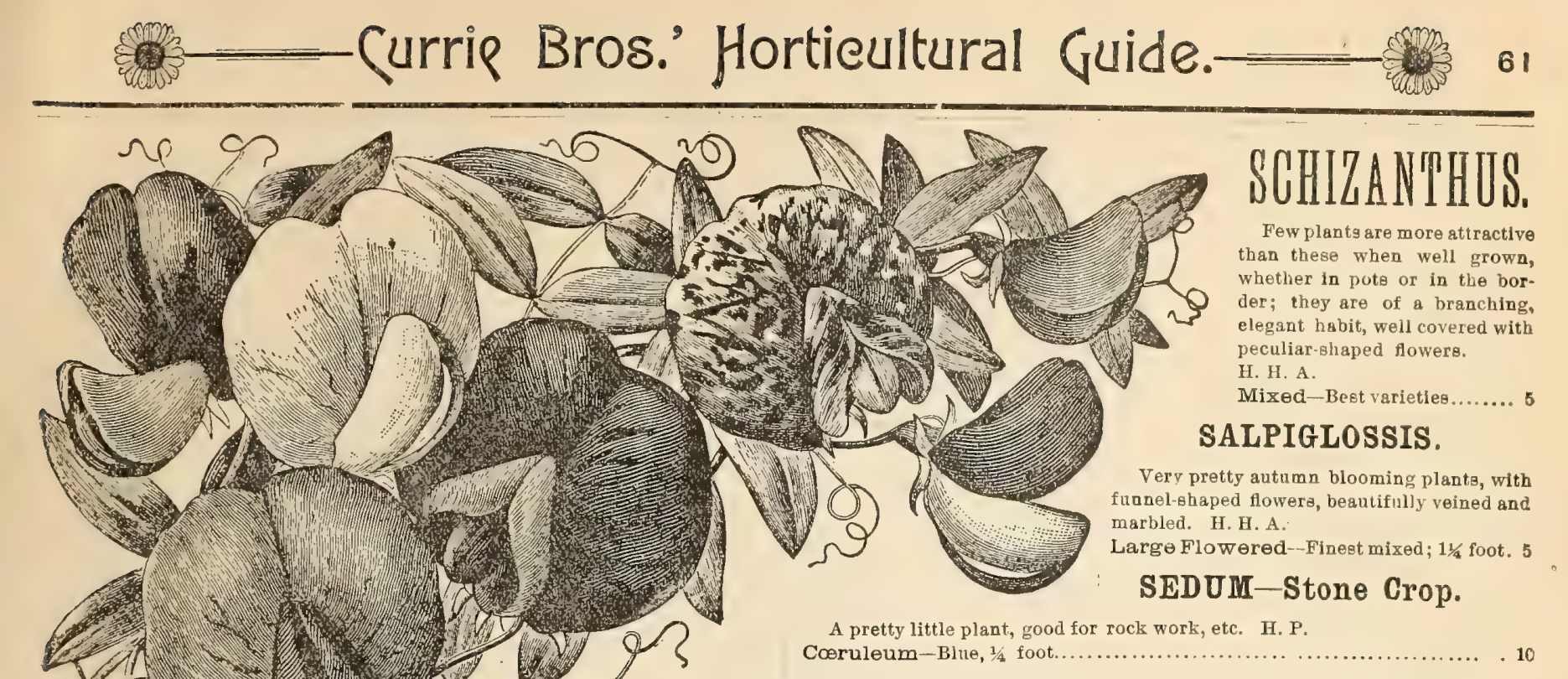

SCABIOSA-Mourning Bride, or Sweet Soabious.

Very desirable plante, producing pretty flowers of many colors in great profusion. Good for cutting for vases, etc. II. A.

Dwarf Double-Flowers very double and globular.................. 5

Stellata - Starry seed veseels; good for winter bouquets ................. 5

\section{SWEET WILLIAM-Dianthus Barbatus.}

Exceedingly beautiful and showy plante, producing an abundance of richcolored flowers throughout the season. H. P.

Auricula Flowered-The flowers of this variety are very large and beauti-

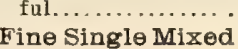

SMILAX.

(See Myrsiphyllum.)

SENSITIVE PLANT.

(See Mimosa Pudica.)

STREPTOCARPUS.

Very pretty greenhouse plants bloom freely. T. P.

New Hybrids-(For description see Novelties).

\section{SWEET PEAS.}

Beautiful, fragrant and free-flowering climbers, continuing in bloom all summer.

Splendour-New, very pretty; color rich rose, shaded crimson.

Primrose-(See Norelties) .......................
Imperial Blue-A new variety, shaded blue...

Orange Prince-A beautiful new Sweet Pea, color pink shading to orange 10

Miss Blanche Ferry-Dwarf, color deep pink and white; per oz., 15 cts... 5 Adonis-A new and very pretty variety, of a rose pink shsde; per oz., 2u cts. 5 Black-Very dark, brownish purple; per lb., \$1.25; per oz., 15 cts............

Blue Edged-White and pink, edged with blue; per 1b., $\$ 1.50$; per $0 z_{0}, 15 \mathrm{cts} .5$ Butterfly-White, laced with lavender blue; per $1 \mathrm{~b}$., $\$ 1.50$; per oz., $15 \mathrm{cts} . . .$. Cardinal-Bright acarlet

Crown Princess of Prussia-Bright blush; per lb , \$1.50; per oz., 15 cts. 5 Fairy Queen-Rosy white; per 1b., $\$ 1.00$; per oz., 10 cts

Indigo King-Rich blue.

Painted Lady-Rose and white; per lb., $\$ 1.00 ;$ per oz., $10 \mathrm{cts.}$

Princess of Wales-White, striped blue; per oz., $20 \mathrm{cts} . .$.

Scarlet Invincible-A beautiful, deep acarlet variety; per lb., \$1.00; per oz., $10 \mathrm{cts}$. ...

Queen of the Isles-Scarlet, mottled white and purple................... 10 Princess Beatrice-New rose.................................. 5 Scarlet, Striped with White-Per 1b., $\$ 1.00$; per oz., 10 cts............ 5 Vesuvius -Rose and violet spotted .............................. 5 Violet Queen-A charming variety, ranging from deep mauve to light violet.10 White-Per lb., \$1 00; per oz., 10 cts.............................. 5 Mixed-All colors; per lb., 75 cts.; per oz., 10 cts.......................

The two following varieties are not climbers, nor are they fragrant, but are nice for vasea or baskets.

Scarlet Winged-Beautiful amsll flowers.

Yellow Winged-Same habit as Scarlet Winged..

The Torenias are very pretty plants for borders, or for house plants, hanging baskets, etc. H. H. P

Baillonii-A free-flowering eort, bearing golden yellow flowers that have a

brownish red throat........................................ 15

Fournierii-This variety is well worthy of special mention. The flower is sky blue, dotted with three dark hlue spots, has a bright yellow throat, and is an exceedingly free bloomer.

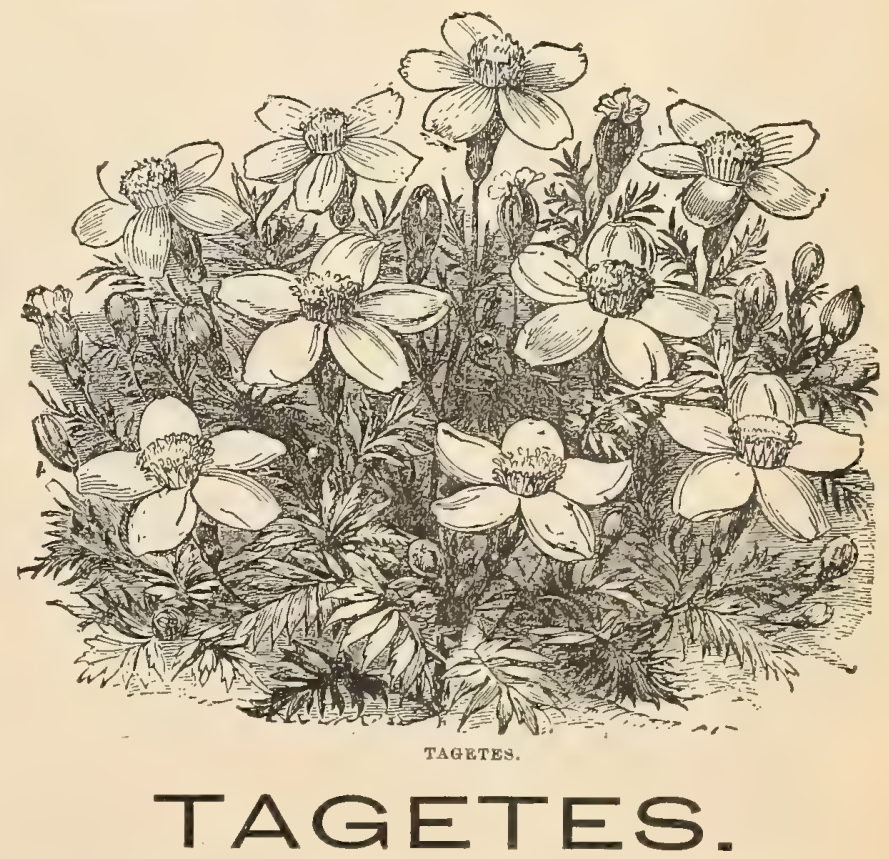

Signata Pumila--A showy, compact plant, covered with bright yellow blossoms, with \& brown stripe through the center of each petsl, H. H. A.. 5 Golden Ring-A new and very showy variety with bright golden flowers. 


\section{2 - Currie Bros.' Hortieultural Guide.}

\section{TROP ÆOLUM LOBBIANUM.}

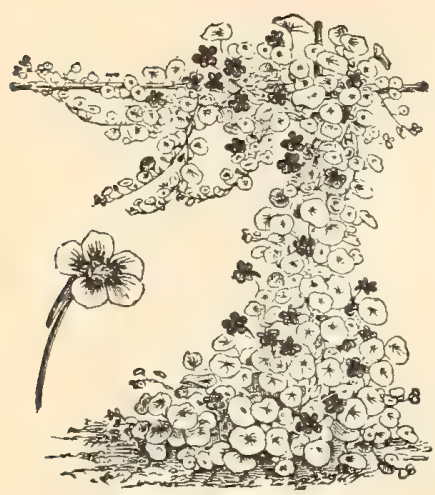

TROP.EOLUM LOBBIANUM

Speciosum-Scarlet

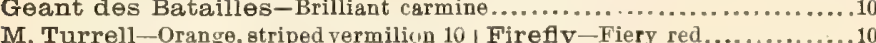
Caroline Schmidt-Scarlet.........10 Lilli Schmidt-Orange scarlet .10 Napoleon III.-Golden yellow, spotted brown......................... 10

\section{THUNBERGIA.}

Ornamental, free-blooming climber of rapid growth. Good for greenhouse culture, or warm situations out of doors. H. H. A.

Alata-Buff with white eye; 4 feet.... 5 | Bakerii--Pure white; 4 feet...... 5 Aurantiaca-Orange, dark eye; 3 feet 5 Mized...................... 5

\section{TRITOMA.}

Interesting and showy plante, popularly known as Red-hot Poker, on account of the color of the flower epikes, which are produced in great profusion and remain a lon $y$ time in bloom. H. P.

Uvaria Grandiflora-Bright orange-scarlet; 4 feet.

\section{VERONICA.}

Very pretty herbaceous plants. H. P.

Glauca-Blue, 2 feet.

\section{VINCA.}

Highly ornamental, free-flowering, compact greenhouse evergreen shrubs, with shining green foliage and handeome circular flowers. T. P.

Alba-White, with crimson eye, $2 \mathrm{ft} .10$ | Rosea-Rose, 11/2 foot.

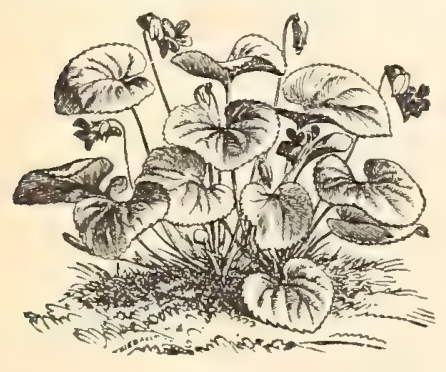

VIOLA-Violet.

A well-known farorite, much in demand on account of its fragrance. H. P.

White.

Blue.

\section{VISCARIA.}

Pretty free-flowering plants, with showy colored flowers, H. A.

Alba-White, 1 foot.

Cardinalls-Magenta, fine, 1 foot. 5

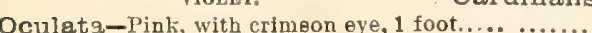

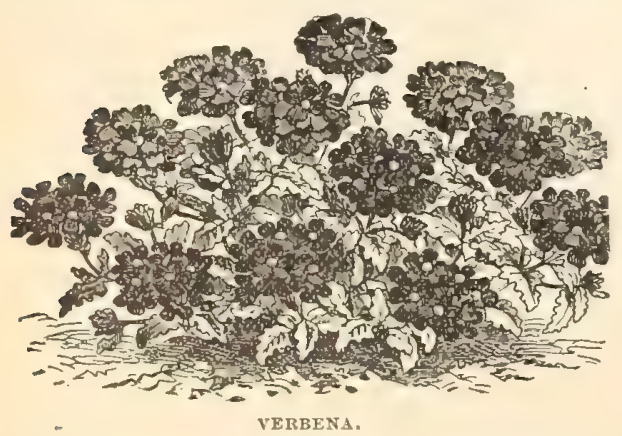

VERBENA.

Well known plants ; blonming freely the first year from seed. H. H. P.

Golden Leaved-

Ite foliage is a very striking and besutiful yellow color, and contrasts admirably with the $\mathrm{v}$ a rious pleasing ehades of the flowers. This va-

riety wlll undoubtedly become very popular. It is a robust grower........15 White........10 | Scarlet.....10 | Purple......10 | Striped.....10 Hybrida - Saved from very choice named varieties, mixed............... 10 Fine Mixed
Hybrida Compacta Candidissima-A new variety of dwarf habit and vigorous growto, color pure white................................ Mammoth Mixed-New etrain of large flowering varieties................. 15

\section{WALLFLOWER.}

A plant much esteemed for ita rich fragrant flowere. H. H. P.

Double-Finest mixed.10 | Golden yellow........10 | Dark brown..........10 Single-Mixed. 5 | Dark brown...10 | Blood red.....10 | Golden vellow..10 Belvoir Castle-Beautiful yellow............................ 10 Cranford Beauty-Deep rich gold..

\section{WHITLAVIA.}

One of the most charming California introductions; very effective for bedding or mixed borders. H. A

Grandiflora-Violet blue, 1 foot.

\section{WIGANDIA.}

Ornamental foliage plenta, with large leaves about 3 feet long by $1 / 1 / 2$ foot wide. T. A.

Caracasana -6 feet

\section{XERANTHEMUM.}

Showy Everlastings ; the flowers, when gathered young, are useful for winter bonquets. H. A., 2 feet.

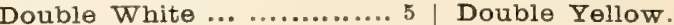

Double Purple

Double Red...

\section{ZEA MAIZE-Striped Japanese Corn.}

An ornamental foliage plant of much besuty. It is a species of Corn, the leaves being beatifully striped with white and green. H. H. A.

Zes Japonica (Fol Variegata)-Striped foliage, 6 feet... Gracillima Variegata-Dwarf striped Corn...

\section{ZINNIA ELEGANS.}

Like Balsams or $\mathrm{Pe}$ tunise, these can be raised to flower by August if sown in the open ground, but if sown under glass in April, they will bloom in June, and throughout the
entire season. H. H. A Doublestriped Per-

fection Zinnia(See Novelties).

\section{ELECANS TOM} THUMB.

A new dwarf c ompact free-flowering variety, grows about 12 inches high, and 14 inches in diameter. The flowers are very large and are produced in great abundance, remaining in bloom until late in the season.

Fine Double Mixed colors.

\section{LARGE FLOWERINC DWARF VARIETIES.} PUMILA, fl. pl.

Sis separate colors: yellow, orange, scarlet, crimson, purple, pare white. Each color.

Extra choice double, mixed, $1 \frac{1 / 2}{2}$ foot

Collection of six separate colors

HAAGEANA, fl. pl.

A tralling variety. Flowers deep orange color, keeping their color when dried.

\section{ZEBRA ZINNIAS.}

A novel clace, producing large double flower, most of which are beautifully striped or blotched.

\section{ZINNIA LINEARIS.}

An interesting and very pretty spieces from Mexico. In growth it is of an erect bush form, growing to height of 12 inches, being profusely covered with flowers 2 inches in diameter of a bright golden yellow color, with light orange margin. The flowers retain their color beatifully when dried..... 10

NEW MAMMOTH FLOWERING ZINNIAS.

Flowers perfectly double, messuring 5 to 6 inches in diameter; colors brilliant. The plants grow about 3 feet high, making a handeome appearance.

Fine mixed colors 


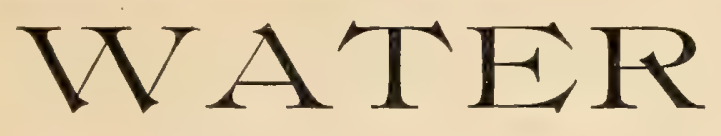

HARDY SORTS.

In ponde and fountains these present an attractive appearance. They grow readily from seed distributed on the water, and when once started take care of themselves without any trouble.

Nymphiza A Iba-Native white pond Lily .......................... 25 Nuphar Lutea-Yellow pond Lily.......................... " 10

Nelumbium Luteum-A beautiful yellow variety, tbrowing ita flow.

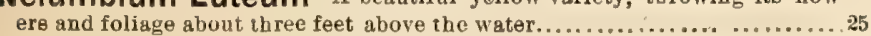

\section{LILIES.}

TENDER SORTS.

May be grown in tanks or tube indoors or outdoors, in enmmer, where the can be taken up and kept in the cellar or out of the way place in winter.

Nymphrea Zanzibariensis-(The Royal Purple Water Lily)-The grandert of all Bine $W$ at $\rightarrow r$ Lilies. Very fragrant, flowers 12 inches in diameter. 50 Nymphrea Lotus-(Egyptian Lotus)-Beautiful large white fowers, suf-

fused with red. This is one of the handsomest of all the Water Lilies, and should be in every collection.

\section{COLLECTIONS OF FLOWER SEEDS-OUR Selection.}

\section{A. GREAT CONVENIENCE TO INEXPERIENCED AMATEUR GARDENERS.}

For the benefit of those unacquainted with flowers but who have gardens which they are desirous of beautifying to the best advantage at a limited expense, we put up and offer the following collections of flower seeds. We wish it thoroughly understood that we put in only those varieties which are most popular and best adapted for the purpose in cur climate. All are very beautiful and useful, and very interesting. The selection being our own, we can afford to give a little reduction from the regular catalogue prices, which is, we know, quite acceptable.

In ordering send the exact amount of money, and name the number of the collection desired. Remember, they are forwarded post-paid.

COLLECTION No. I.

Contains 18 choice and distinct annuals, 1 pkt. of each. Price, $50 \mathrm{cts}$.

Aster.

Balsam.

Calliopsis.

Dianthus.

Codetia.

Calendula.

Mignonette.

Nasturtium.

Poppy.

\section{COLLECTION No. 2.}

Portulaca

Scabiosa.

Sweet Alyssum.

Phlox Drummondii.

Pansy.

Marigold.

Stocks.

Chyrsanthemum.

Clarkia.

COLLECTION NO. 2.

Contains 30 choice and distinct annuals, 1 pkt. of each. Price, 75 cts. Same as No. 1 with the addition of

Morning Clory.

Eutoca.

Eschscholtzia.

Larkspur.

Petunia.

Salpiglossis.

\section{Verbena.}

Viscaria.

Zinnia.

Schizanthus.

Saponaria.

Antirrhinum.

\section{COLLECTION No. 3.}

Contains 40 choice and distinct annuals, biennials and perennials, 1 pkt. of each. Price, 1.00 . Same as No. 2 with the addition of

\begin{tabular}{l|l} 
Ricinus. & Patava. \\
Potentilla. & Momordica \\
Perrilla. & Lychnis. \\
Myosotis. & Ipomza. \\
Palafoxia. & Ipomopsis.
\end{tabular}

COLLECTION No. 4.

Contains 65 choice and distinct annuals, biennials and perennials, 1 pkt. of each. Price, $\$ 150$. Same as No. 3 with th $\rightarrow$ addition of
Six separate colors of Zinnia.

Six separate varieties of Poppy.
Six separate colors of Phlox.

\begin{abstract}
Six separate varieties Tall Nasos turtium.

1 pkt. Marguerite Carnation.
\end{abstract}

\section{CLIMBERS.}

Ten varieties, including Gourde, Cohæa, Nasturtium, etc. Price, 40 cts.

\section{MIXTURES OF FIOWER SiEEOS.}

We are frequently asked for mixtures of various sorts, and to meet this demand we have prepared the following list of varieties, all of which will be found very satisfactory where an assortment is desired.

Mixture of Fragrant Annuals.

Composed of seed of Fragrant Flowere only, many of which are also suitable for cutting................................................ 10 ets.

Mixture of Tall Growing Annuals.

Consisting of Annual Flowering Plants, growing a foot high and upwards ................................................ $10 \mathrm{cts}$.

\section{Mixture of Dwarf Growing Annuals.}

This will be found an excellent mixture, embracing, as it does, a variety of choice annual plants growing six inches high and under.....10 cts.

\section{Mixture of Annuals for Bouquets.}

A very desirable mixtare, composod of varieties, with long stemmed flowere suitable for bouquete and vases, and may be depended upon for a constant supply of bloom .............................................. 10 cts.

\section{Mixture of Foliage Plants.}

Embracing Annuals grown almost exclusively for their foliage, many of which are very handsome....................................10 cts.
Mixture of Evening Blooming Annuals. This mixture is composed of low growing plants, which bloom in the afternoon and evening; many of them are very handsome............... 10 cts. Mixture of Climbing Annuals.

This mixture will be found very desirable, being composed of many beautiful climbers, all of which will prove useful for growing npon trellises,

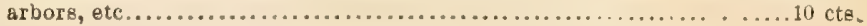

Mixture of Everlasting Flowers.

All the varieties will prove very desirable for winter bouquets............10 cte.

Mixture of Biennials and Perennials.

Some of the varieties contained in this mixture will bloum the first year if planted early, while others will bloom the second year, and many of them continue to come up and bloom for many years...................... 10 cts.

Mixture for Wild Flower Garden.

A grand mixture embracing numerous varieties of pretty Flowering Annuals, that will give a continuous display of bloom throughout the season. Per oz., 25 cts. Per Pkt................................. 10 cte 
FOR CONSERVATORY, PARLOR AND LAWN.
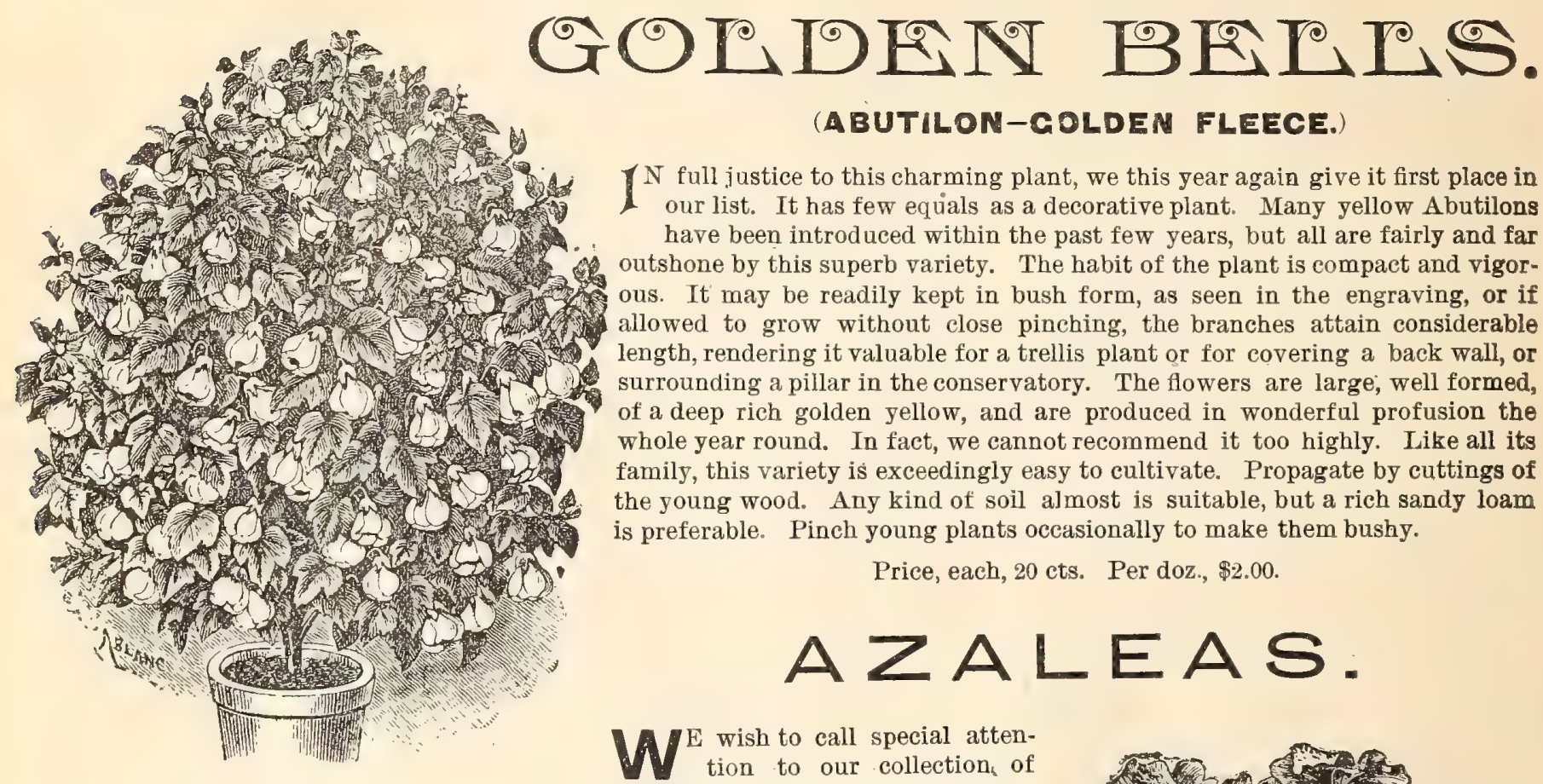

(ABUTILON-GOLDEN FLEECE.)

$1 \mathrm{~N}$ full justice to this charming plant, we this year again give it first place in our list. It has few equals as a decorative plant. Many yellow Abutilons have been introduced within the past few years, but all are fairly and far outshone by this superb variety. The habit of the plant is compact and vigorous. It may be readily kept in bush form, as seen in the engraving, or if allowed to grow without close pinching, the branches attain considerable length, rendering it valuable for a trellis plant or for covering a back wall, or surrounding a pillar in the conservatory. The flowers are large; well formed, of a deep rich golden yellow, and are produced in wonderful profusion the whole year round. In fact, we cannot recommend it too highly. Like all its family, this variety is exceedingly easy to cultivate. Propagate by cuttings of the young wood. Any kind of soil almost is suitable, but a rich sandy loam is preferable. Pinch young plants occasionally to make them bushy.

\section{Price, each, 20 cts. Per doz., \$2.00.}

\section{AZALEAS.}

$W^{B}$ mish to call special attanABUTILON-GOLDEN FLERCE.

Azaleas this season. The plants are Large, bushy, well-formed with abundance of foliage, and thickly set with buds. The collection embraces all the leading varieties all named. It is with special pride and conGidence we recommend these beautiful plants to our customers.

Price, each, $\$ 1.00$ to $\$ 3.00$. We ship by express only.

\section{ALIAIMANOA SCETOTTII.}

THS elegant evergreen greenhouse climber is of such excellence that we earn-
estly recommend it to every plant grower who has a greenhouse or conservatory. It is very easily cultivated, and grows rapidly when once established. For training up a rafter or pillar, or on the back wall of the greenhouse, it is invaluable. The leaves are about five inches long, and about one inch wide and pointed, are light green and

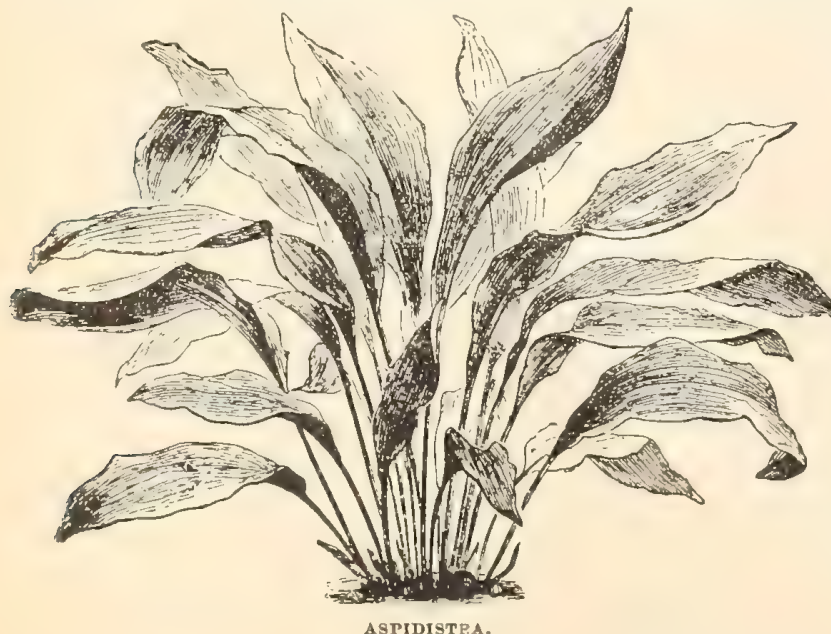
glossy. Flowers large and funnel-shaped, and of a rich canary yellow.

Price, each, 25 cents.

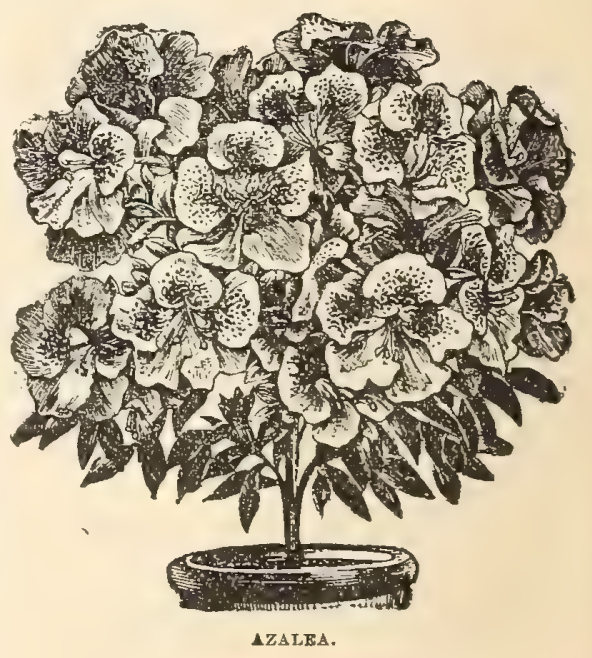

\section{ASPIDISTRA.}

A S a house plant, cultivated for its foliage only, we can confidently say the Aspidistra is surpassed by none, and, in fact, has few equals. The leaves are oblong-lanceolate on long stems, just slender enough to give the plant a very graceful appeirance. The leaf proper usually grows about a foot and a half in length, and is about four inches in breadth at its widest part. As the plant grows and increases in size it assumes a bushy form, the leaves all springing from a common crown or stool. The common species, Lurida, has plain dark green foliage. We have also a very pretty variegated variety, the leaves being alternately striped with white and green. Both kinds, but the common green particularly are very easy of cultivation, in fact nothing but positive and continued neglect will kill them. This plant should be in every collection.

Price, green variety, each, $25 \mathrm{cts}$. Variegated variety, each, 50 cts. (See Abridged List for_General Collection.) 


\section{Currie Bros.' Hortieultural Guide.——}

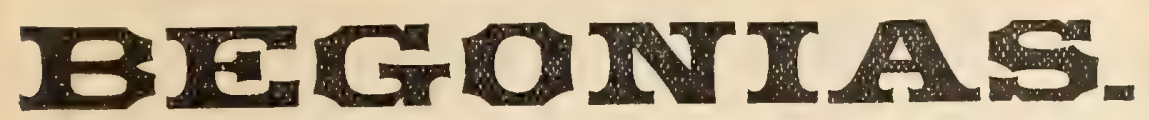

\section{A Collection of the Newest and Most Beauti- ful Kinds yet Introduced.}

0 ornamental plants have advanced so much in popularity as the large 1 family of Begonias, and certainly none merit the attention and admiration bestowed on them more than do these beautiful and very useful plants. What can be more ornamental than the bold, handsomely marked foliage of the Rex varieties, or what more decorative than the many flowering kinds which are also so useful for cutting, or more beautiful than the gorgeous, delicately tinted blossoms of the Tuberous-Rooted kinds now so popular? The numerous species are divided into three distinct classes, the Rex, the so-called Flowering, and the Tuberous-Rooted.

All are excellent house plants, and no conservatory collection is complete without them.

\section{FLOWERING VARIETIES.}

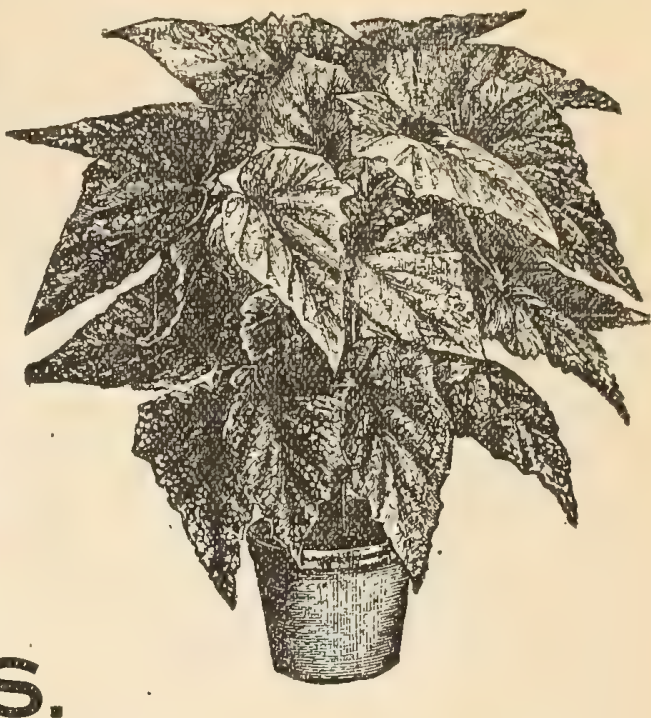

\section{GRAND NEW BTGONIA, INCARMATA COMPACTA.}

A SIGHT of this magnificent flowering Begonia would instantly convince the beholder that any praise, however lavishly $A$ bestowed upon it, could not be overdrawn, but would simply be doing the plant the justice it so thoroughly merits. It resembles that old and really excellent species Incarnata, but the plant is more compact, as the name implies, and the flowers are borne in much larger trusses and in such profusion as to fairly hide the foliage in a rich clothing of the most delicate pink blossoms. It is a robust grower and sure flowerer. Price, each, 25 cts.; per doz., \$2.50.

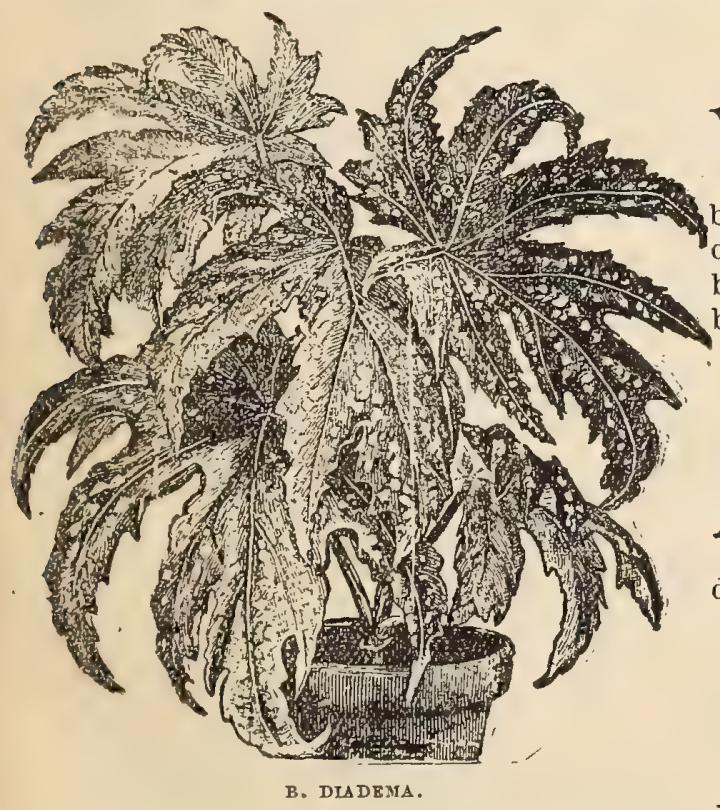

\section{NEW BEGONIA, ARGENTEA GUTTATA.}

W regret very much that we have been unsuccessful in procuring a good engraving of this superb Begonia. Words even fail us to describe it as it deserves to be. Suffice it to say it is one of the best, the most beautiful, the most useful for conservatory or parlor decoration, and moreover of as easy cultivation as any Begonia yet introduced. The leaves are oblong, a beautiful purple bronze, mottled with clear silvery markings. Flowers white, borne on the extremities of the branches. Price, each, 25 cts. Per doz., \$2.50.

\section{NEW BEGONIA, MARGARITAE.}

VERY great improvement on that favorite, Metallica, which it resemA bles somewhat in the rich bronze-green of its foliage, but in form it is more bushy, and is a strong, sure grower. Flowers rose-colored, produced very abundantly in large, full trusses.

Price, each, 25 cts. Per doz., $\$ 250$.

\section{NEW BEGONIA, PAUL BRUANT.}

A VERY handsome variety of vigorous habit, upright and bushy in growth, $A$ and a very free bloomer. The flowers are large, rose and white in color and borne, on long graceful stems. Flowers from November to May. Price, each, 25 cts.

\section{NEW BEGONIA, DIADEMA.}

THE excellent cut we present of this new Begonia renders a description unnecessary. One feature particularly worthy of I. mention is its thorough adaptability for house culture. It will, therefore, be hailed with delight by all who cultivate plants In their homes. Price, each, 25 cts.

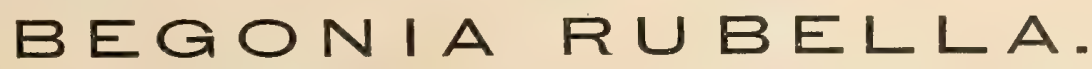

A VERY beautiful species of this very popular family of plants, and should be in every collection. It succeeds admir. 1 ably in the house, and is for that purpose an exceedingly handsome object. The leaves are large, blotched with red on a pale green ground, the under surface being a bright red. Price, each, $25 \mathrm{cts}$. 


\section{MANICATA AUREA.}

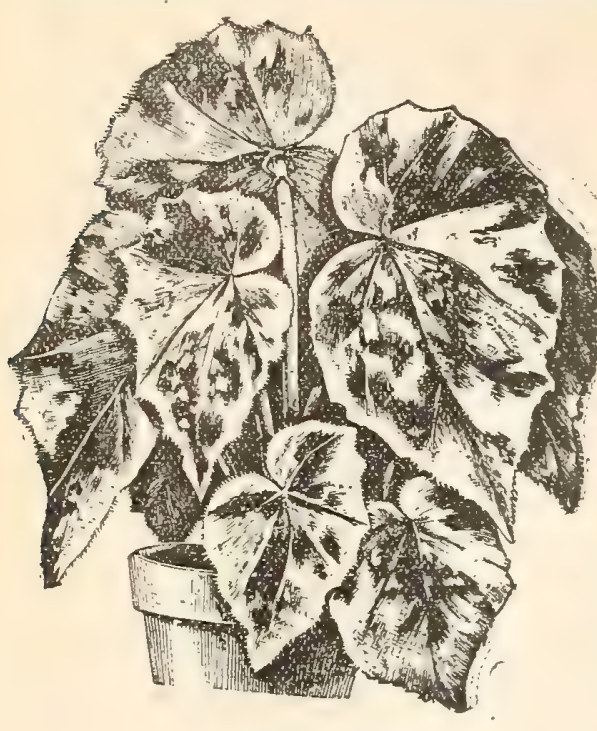

B. MANICATA AUREA

THOSE of our customers who are familiar with that old but excellent Begonia, Manicata-and nearly all must be, for it is universally popular-know how very beautiful, and how exceedingly useful it is for greenhouse and parlor decoration. Its large dark green, glossy leaves, and wealth of delicate pink flowers, so gracefully borne on long, erect and finely dividing flower stems, render this plant an exceedingly pretty and striking object. Add to all that beauty, foliage, instead of being plain green, which is handsomely variegated with large blotches of canary yellow, and you have one of the most beautiful plants imaginable. Manicata Aurea is all that and more, if we could but describe it. The accompanying cut is a very good and faithful representation of it. Price, each, 25 cts.

\section{NEW BEGONA, SUTTON'S SNOWFLAKE.}

MONG all the flowering Begonias this one takes rank close to first place. It is A a robust and rapid grower and produces an abundance of large, pure white blossoms on long stout stems, which are excellent for cut-flowe
As a house plant no plant surpasses this Begonia. Price, each, 25 cts.

\section{$B E G O N \mid A$ A L BO-PICTA.}

FEW plants are more attractive and more decorative than this Begonia. The habit of the plant is bushy. Branches upright and graceful; leaves slender and pointed, glossy green, and thickly spotted with silvery-white specks. Flowers pink, and produced abundantly. Price, each, 25 cts. Per doz., $\$ 2.50$.

\section{NEW BEGONIA, SEMPERELORENS GIGANTEA ROSEA.}

A STRONG, upright grower, having smooth and glossy leaves. Flowers a beautiful cardinal red, borne on long strong stems. A Few plants equal this one for decorative purposes. An excellent house plant. Price, each, 25 cts.

\section{NEW 囚玉G゚}

A RECENT introduction of rare merit. Laaves very large and deeply cut into sharp pointed segments. The young leaves A are very beautifully colored, the older ones being prettily shaded with brown and red. Flowers lemon white, large. A very desirable variety. Price, each, 25 cts.

\section{YERY DESIRABLE ALTHOUGH NOT NEW VARIETIES.}

HYDROCOTYLIFOLIA-An excellent house plant, very attractive leaves, large and smooth, almost round. Plant low growing and compact. Flowers pink, very freely produced on spikes.

INCARNATA-One of the best flowering Begonias grown. A very old favorite and always in demand. Flowers a rich rosy pink, produced in mid-winter in great profusion.

MANICATA-Too well known to need particular mention. Everybody's favorite. Flowers pink.

METALLICA-Surface of leaf a rich, lustrous metallic tint or bronze color. Flowers white, very freely produced. Habit,"of plant bushy.

SANDERSONII-A grand old variety. Leaves dark green and glossy. Flowers a very brilliant scarlet. Each, 15 cts. to $25 \mathrm{cts}$, according to size.

\section{REX VARIETIES. REX BEGONIA-COUNTESS LOUISE ERDODY-NEW.}

THE peculiar feature of this new variety is the curious spiral formation of the leaf, as seen in the engraving. But aside from this interesting point, this variety has much to commend it. Its foliage is beautifully marked and shaded with silvery gray and coppery-rose, the veins on both sides being a yellowish green. Price, each, 25 cts.

\section{BEGONIA REX LOUISE CHRETIEN.}

1 LTHOUGH not quite new, this superb variety has actually no equal in its family, so $A$ that it is still entitled to a foremost place in a list of novelties. The beautiful coloring of its foliage is almost indescribable; but when we say that it is like changeable silk in its luster, we may possibly be understood. Flowers large and of a delicate rose tint. Price, each, 25 cts.

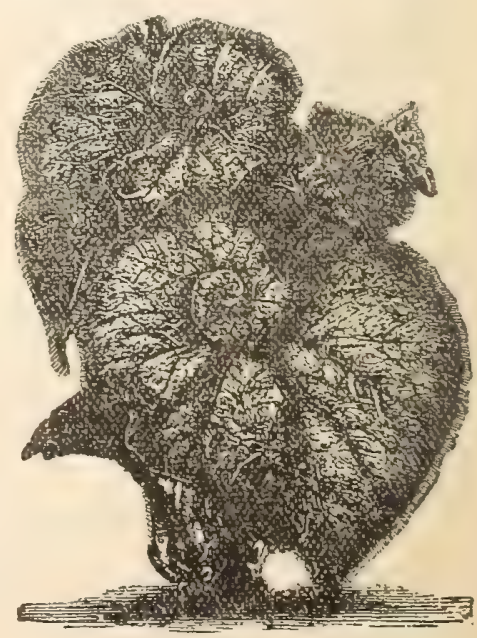

B LOTISE ERDODY. 
a

NEW Rt-

AINGUlarlīX BEGONIA,

ADRICOLOR. white; edge silvery each, 25c.

d, surro

\section{NEW REX BEGONIA-MADAM TREYVE.}

$\Lambda \mathrm{N}$ exceedingly pretty and distinctly upright growing kind. A A broad zone of green, bordered by a narrow edge of brownish plum color, encircles each leaf. Price, each, $25 \mathrm{c}$.

\section{NEW REX BEGONIA, INIMITABLE.}

A very desirable variety. Foliage a metallic steel color and glossy. Price each, 25 cents.

\section{REX BEGONIAS - STAMDARD SORTS.}

N. B. - We have a very extensive assortment of varieties of earlier introductions, but all selected and excellent. Our limited space does not permit us to catalogue them by name, but any one wishing a collection, and entrusting us with the selection will, we feel safe in saying, be entirely satisfied with what they receive. Price each, 25 cts. Per doz.; $\$ 2.50$.

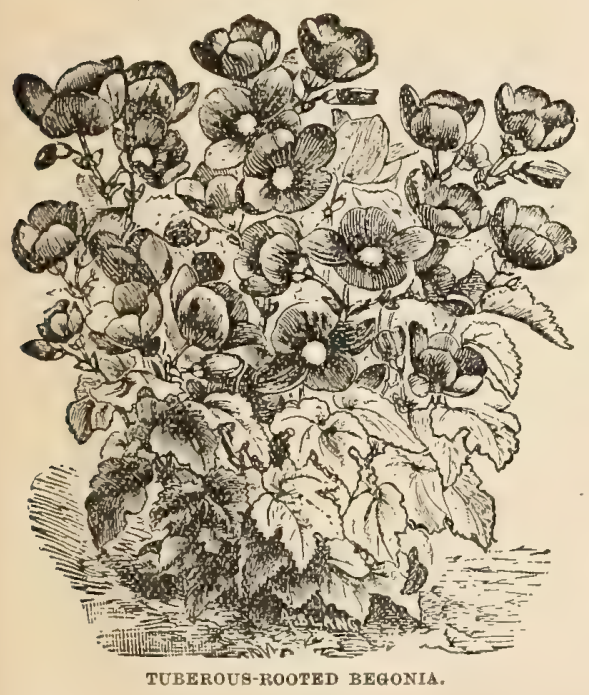

\section{TUBEROUS-ROOTED BEGONIAS.}

- VERY succeeding year, as this class of Begonias becomes better known, the demand for them keeps increasing. All the varieties are beautiful, many of them charming. The flowers of all of them are much larger than those produced by any of the other sorts; and some of them bear flowers of an almost incredible size. Not unfrequently we see them four inches in diameter. Furthermore, the numerous varieties produce many colors, varying through all the shades of crimson, scarlet, orange and yellow, and many are pure white. They are readily raised from seed, the young plants soon forming bulbs or rather tubers, which annually alternately become dormant and push into growth, perpetuating the plant for an indefinite number of years.

Seeds should be sown early in spring and will produce flowering plants the same season. As growth ceases, gradually dry off the plants until the foliage and branches are decayed. Keep the bulbs perfectly dry until early the following season, when again pot and start them. We have a very fine assortment of large tubers, of many very choice varieties and colors, which we offer as follows:

\section{NORT BUTIBS.}

Single, all colors mixed, each 15 cts.; per doz..........\$1.50| Double, in colors, rose, white, crimson, scarlet, yellow, salSingle, in colors, scarlet, white, salmon, rose, pink, crimson,

yellow, each 20 cts.; per doz.................. 2.00

Double, all colors mixed, each 35 cts.; per doz......... 3.50

mon, each 50 cts.; per doz.

$\$ 5.00$

Plants of the several kinds in all stages of growth, in pots, 25 cts. to $\$ 1.00$ each.

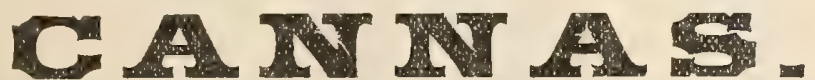

New Flowering French Warieties:

$\sqrt{6}$

HE most effective arrangements imaginable in lawn or flower-garden embel 1 lishment are accomplished by the judicious use of Cannas, whose varied colored, large and luxuriant foliage lend a tropical air to the surroundings. A single plant in the center of a bed of other plants is always effective; but a bed, especially if it be a large one, filled with these plants alone, using a variety of them and contrasting their varied colored foliage, is a most charming sight. The effect is heightened by planting around them a row or perhaps two of Caladium Esculentum. Hitherto we have been contented with the effects produced by the foliage alone, placing but little value on the flowers. But now we have an entirely new class of these plants, combining with the splendid foliage peculiar to their family flowers of such wondrous beauty as to rival those of the handsomest Gladioli which they resemble very much in form. These flowers are produced in great eluster throughout the entire summer. More than that, if the plants are taken up care fully in fall they will bloom quite as freely all winter. They are certainly a great acquisition.

We have a large assortment of the leading varieties producing according to their kinds, red, crimson, yellow, orange, striped and many tinteā blossoms. Price. each, 30 cts.; 3 for 70 cts.; per doz., $\$ 3.00$.

\section{General Collection of Older Sorts.}

In variety, price each, 2 cts.; per doz., $\$ 2.50$.

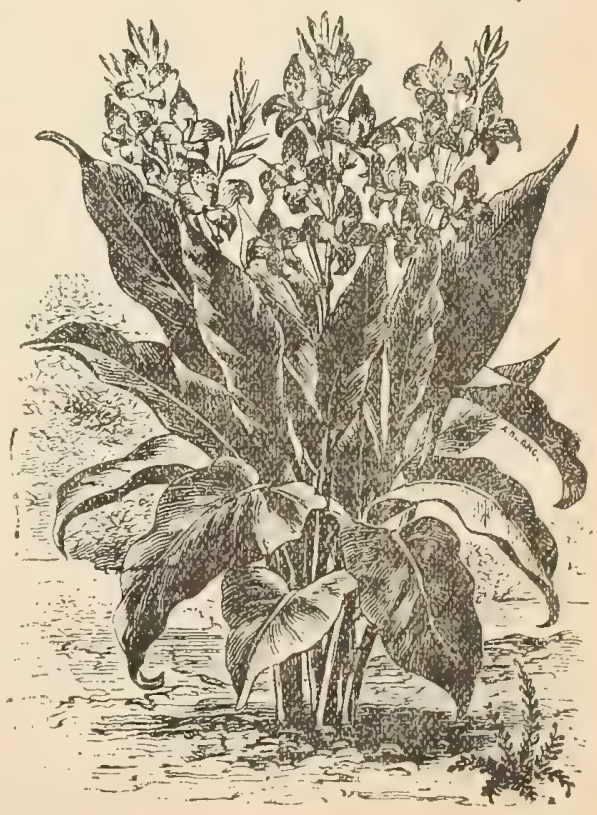

CANNAS. 


\section{8 - Currip Bros.' Hortieultur}

Guide.

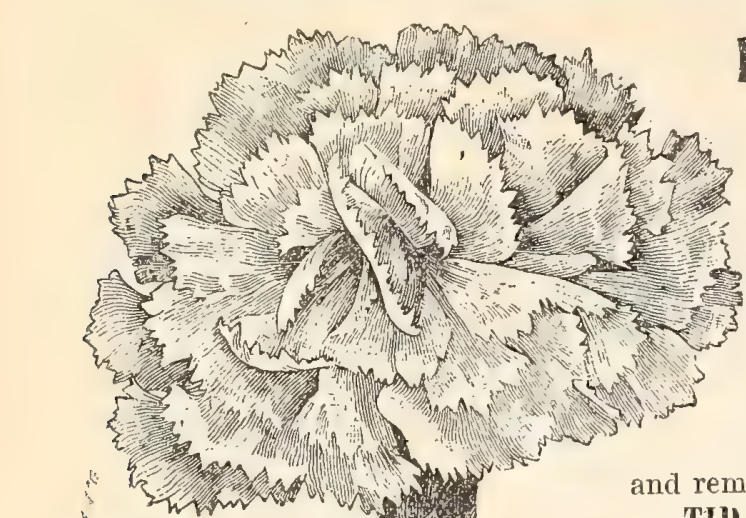

CARN ITIO-AT.

THERE are no flowers more a rion than Carnations. Their cultivation is of a siming of cultivat - aey respond to the very little attention required by proture and t eat abundance of flowers. Those we name are the very best or a gr wass. All bloom profusely at any season of the year-it being only ${ }^{\prime}$, wessary to prepare them for the season desired-and all are especially adapted for winter flowering. If for the latter purpose, propagate by cuttings about the month of January. As early in spring as the weather will permit plant in the garden. Pinch them two or three times, according to the growth they make, the object being to make them bushy. Take up about the middle of September, pot

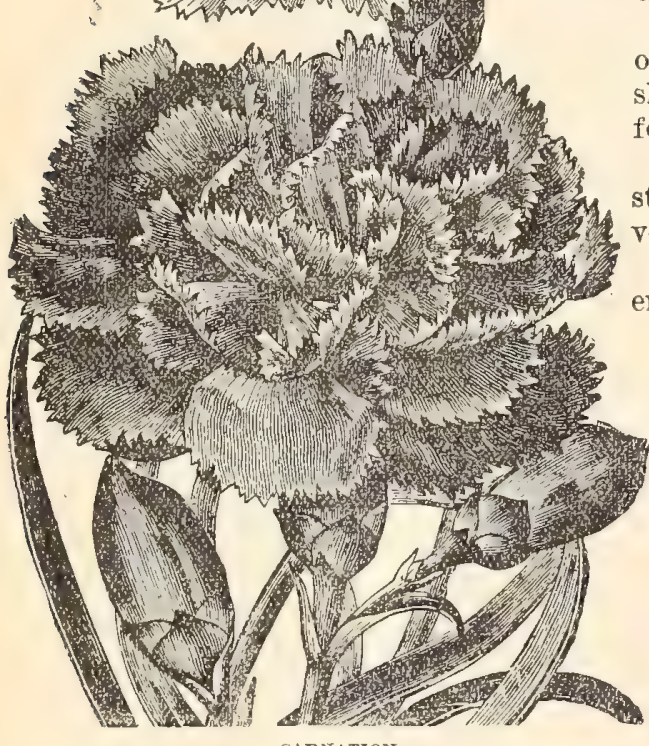

CARVATION

TIUAL WAVE-This new variets stands pre-eminently at the head of the list of pink Carnations. The color is a beautiful clear pink. In habit the plant is shrubby and robust, and it is a very profuse bloomer, the flowers being perfect in form. See lower flower in cut.

SILVER SPRAY-Best white variety ever introduced. Flowers borne on long stems, large and perfect in form, and never burst. A most profuse bloomer, and very fragrant. See upper flower in cut.

JAMES A. GARFIELD-An excellent Carnation. A strong dwarf grower; flowers large and perfect in form, bright scarlet, and very fragrant.

MRS. GARFIELD-Very like the preceding in habit, size and form of flower, but the color is a rich, very pleasing shade of pink.

GRACE WILDER-An excellent variety and now very popular. Its flowers are always in great demand. They are a delicate pink, and are profusely produced.

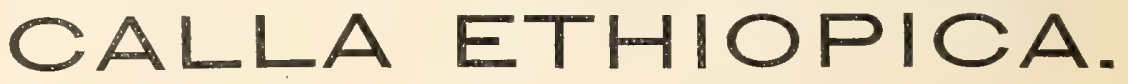

(Lily of the Nile.

W ${ }^{\mathrm{E}}$ have a very fine stock of this popular plant in all sizes, which, con-

sidering their size and strength, are very cheap. Price, each, 25 cts. to $\$ 1.0 \mathrm{0}$.

VARIEGATED CALLA (Richardia Albo Maculata)-A summer blooming variety of rare beauty. The flowers are smaller than those of the common Calla, and are creamy white, but the most attractive feature of this plant is its remarkably pretty, variegated foliage, which is green and strikingly marked with irregular blotches of white. Like Ethiopica, the root is perennial, and is usually dormant during winter, starting into growth again early in 'spring, when it should be repotted into fresh soil.

Price, each, 25 cents.

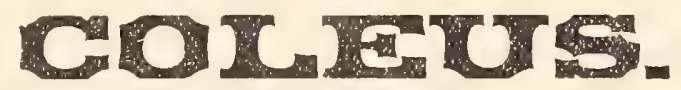

\section{New and Especially Desirable Varieties.}

THE great and continually increasing popularity of Coleus, or

as they are commonly called, Foliage Plants, a popularity well merited because of their beauty and general usefulness for decorative purposes, has offered many inducements to hybridizers, with the result that every year many new varieties are produced. It follows, as a matter of course, that many of them while good are in no particular superior to those already in cultivation. It was our fortune, however, to secure a set last year, which we offered for the first time, which are so superior, being wondrously beautiful, that we again catalogue them with no additions, because we have found none superior. They are beautiful indeed, no description being adequate to convey a correct idea of their many lovely tints and wonderful and

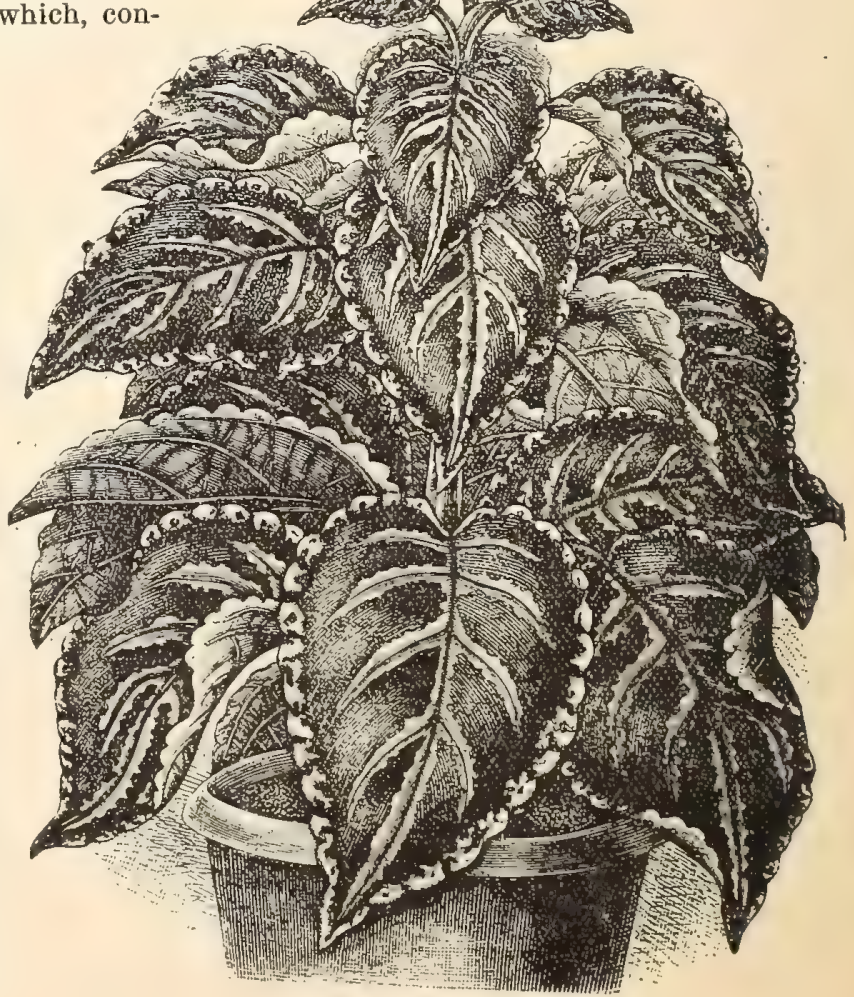

COLEUE. 


\section{1 \\ - Currie Bros.' Hortieultural Guide.——— - -

harmonious arrangement of colors. Whether in beds or as specimen pot plants, they are striking objects and delight the eye.

VEXUS-Leaf resembling brocaded velvet, in large blotches of vermilion, carmine and buff; under surface of leaf brilliant pink.

JUPITER-Flame red, edged with gold; a beautiful variety.

MERCURY-Large leaf, embossed with green and gold, overlaid with a network of brilliant crimson veins.

MARS-Large heart-shaped leaves, finely mottled with dots of crimson on a ground of brilliant chrome yellow.

NEPTUNE-Serrated leaves overlaid with a beautiful combination of brown, green, lemon and carmine.

SATURN-A remarkably beautiful sort, having a broad stripe of clear white down the center of the leaf; spotted and veined rosy violet.

URANUS-Center of leaf greenish yellow, surrounded by a broad band of cinnamon red.

SIRIUS-A beautiful variety with pointed leaves. Center bright vermilion with chocolate zone on violet ground.

RHEA-Bright green, marked and blotched with purplish crimson, edged with yellow.

JUNO-Ground of yellow and green, striped and marked with crimson.

CERES-Deeply cut leaf, bronze green, center creamy white and crimson.

Price, each, 15 ets.; per.doz., $\$ 1.25$. Set of 11 sorts, $\$ 1.00$.

\section{POPULAR BEDDING COLEUS.}

The following varieties have proved themselves specially useful for massing in beds and borders, where it is"desirable to produce a striking effect with solid colors:

ACME-Pink, brown and yellow.

HER MAJESTY-Golden bronze.

GOLDEN BEDDER-Best yellow.

JOHN G00DE-Greenish yellow.

VERSCHAFF ELTII - Maroon; a general favorite.

PROCrRESS-Green ground, mottled with brownish spots.

Price, each, 10 cts.; per doz., $\$ 1.00$. Per 100 , our selection, $\$ 6.00$; per 100 , customers' selection, $\$ 7.00$.

\section{CYPERUS ALTERNIFOLIUS.}

\section{(UMBRELLA PLANT.)}

This well-known plant, always popular, seems now to be in greater demand than ever it was. It well deserves the attention it is attracting, for it is a pretty, unique and striking object. Moreover, it is of very easy culture, growing and thriving under almost positive neglect. Being an aquatic it is at home in the aquarium, but it succeeds equally well as.an ordinary pot plant, if only an abundance of water is given it. Next to Palms this plant deservedly takes rank among the most beautiful and most useful foliage plants for house culture. Price, each, 25 cts. to $50 \mathrm{cts}$.

\section{FUCHSIAS.}

$\mathrm{H}$ ROM a large and varied collection of these popular plants we have selected a few of the very best which we offer in the full confidence that they will invariably give satisfaction.

BULGARE-Sepals brilliant red, corolla violet, a free bloomer ; single.

BLACK PRINCE-Tube and sepals carmine, corolla rose, a profuse bloomer; single.

ELM CITY-Sepals crimson, corolla purple, very large and full; double, an old favorite.

FRAU EMMA TOPFER OR STORM KING-A superb variety, very large and double, sepals bright crimson, corolla white suffused and veined with delicate rose. Each 15 cts.

MRS. E. G. HILL-(See cut). Flowers very large and double; corolla pure white, sepals dark red. A grand variety and very free bloomer. Each, $15 \mathrm{cts}$.

MRS. MARSHALL-An excellent variety; corolla carmine, tube and sepals white; single.

PRINCE ALBERT-Resembles that old favorite Speciosa although much more desirable; single.

ROSAIN'S PATRIE-Sepals rosy carmine, corolla white; double. A very desirable variety. Each, 15 cts.

Price, except where noted, each $10 \mathrm{cts}$. Per doz., \$1.00.
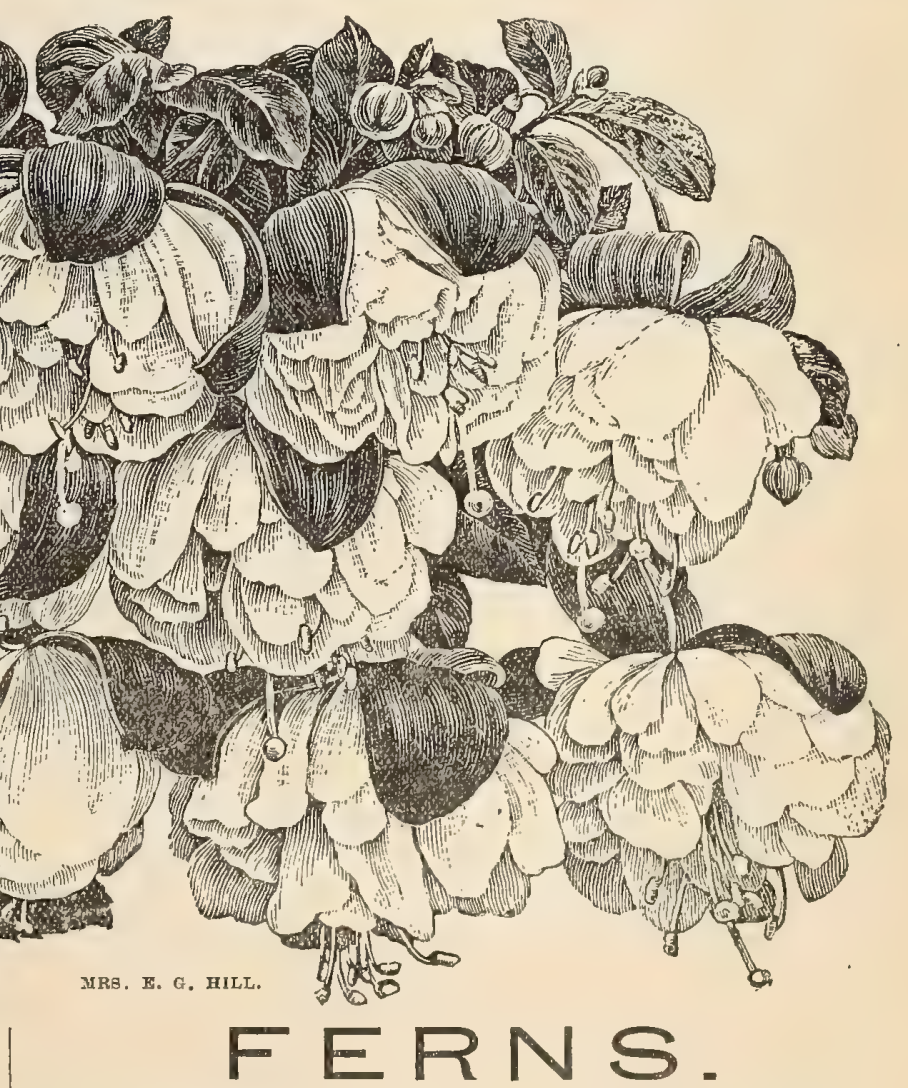

TS conservatory specimens, parlor ornaments, or for general decorative purposes the many delicate, beautiful species smaller kinds are admirably adapted for planting in rock work in the conservatory and for the fernery in the parlor. Our collection is large and varied.

Price, 25 cents and upwards, according to variety and size. 


\section{CHRYSANTHEMUMS.}

OUR SELECT LIST OF THE NEIVEST AND BEST.

UT of more than a hundred varieties
which we grow, all of them really
good, we have selected the following which we offer with the full assurance that since there are no better in cultivation, each and every one is sure to prove satisfactory to our customers. They are really beautiful beyond description, many of them producing flowers six and even eight inches in diameter.

*ADA SPAULDING-Peach pink, 15 cts.

AQUIDNECK-Peach pink.

BELLE PAUL-White, striped with rose.

*CITRON-Yellow.

*BEACON-White (new), 20 cts.

CULLINGFORDII-Crimson.

COQUETTE-Mahogany.

*DOMINA TION-(Bassett's White)-White.

DIANA-White, medium size.

ELEGANTISSIMA-Pink.

*EXCELLENT-Pink, 15 cts.

*ETOILE DE LYON-White (new), 20 cts.

*EORGEOUS-Y ellow.

*GLORIOSUM-Yellow.

GOLDEN GEORGE GLEYNY-Yellow.

*HARRY E. WIDSER-Yellow, 15 cts.

H. CANNELL-Yellow.

IVORY - White, 15 cts.

JESSICA-White, lemon center.

J. V. FARWELL-Red.

*KIOT0-Yellow, 1 ó cts.

LA ROUFF-White.

*L'TR IOMPHANTE-Light pink

*L. B. BIRD-Pink.

*L. CANNIYG-White.

LOUIS BOEHMR-Pink Ostrich Plume, 20 ets.

MISS MEREDITH-Rose (new), 20 cts.

*MRS. ALPHEUS HARDY-White Ostrich Plume, 1 cts.

* IINMIE WANAMAKER-White (new), 20 cts.

MRS. ANDREW CARYEGIE-Maroon.

*MISS M. WHEELER-Rose (new), 20 cts.

MRS. GEORGE W. CHILDS-Bronze, tipped with yellow.

* MRS. E. W. CLARK-Red.

IRS. BEAL-White.

*IRS. LA YGTRY-White.

*IRS. HUMPHREYS-White:

MOONLIGHT-Creamy white.

*0RIOLE-Bronze (new), 20 cts.

*PRES. ARTHUR-Pink.

TOKEO-Red.

*VIOLET ROsE-Pink (new), 20 cts.

VEIL D'OR-Old Gold.

*W AB $\mathbf{N}$-Pink (new), 20 cts.

W. W. COLEs-Bronze.

*W. H. LIXCOLN-Tellow.

YELLOW PRIYCE-Tellow.

Except where noted, price each, 10 cts., per doz., $\$ 1.00$.

Those marked * are exceptionally fine kinds. All of them of very recent introduction, and some of them new.

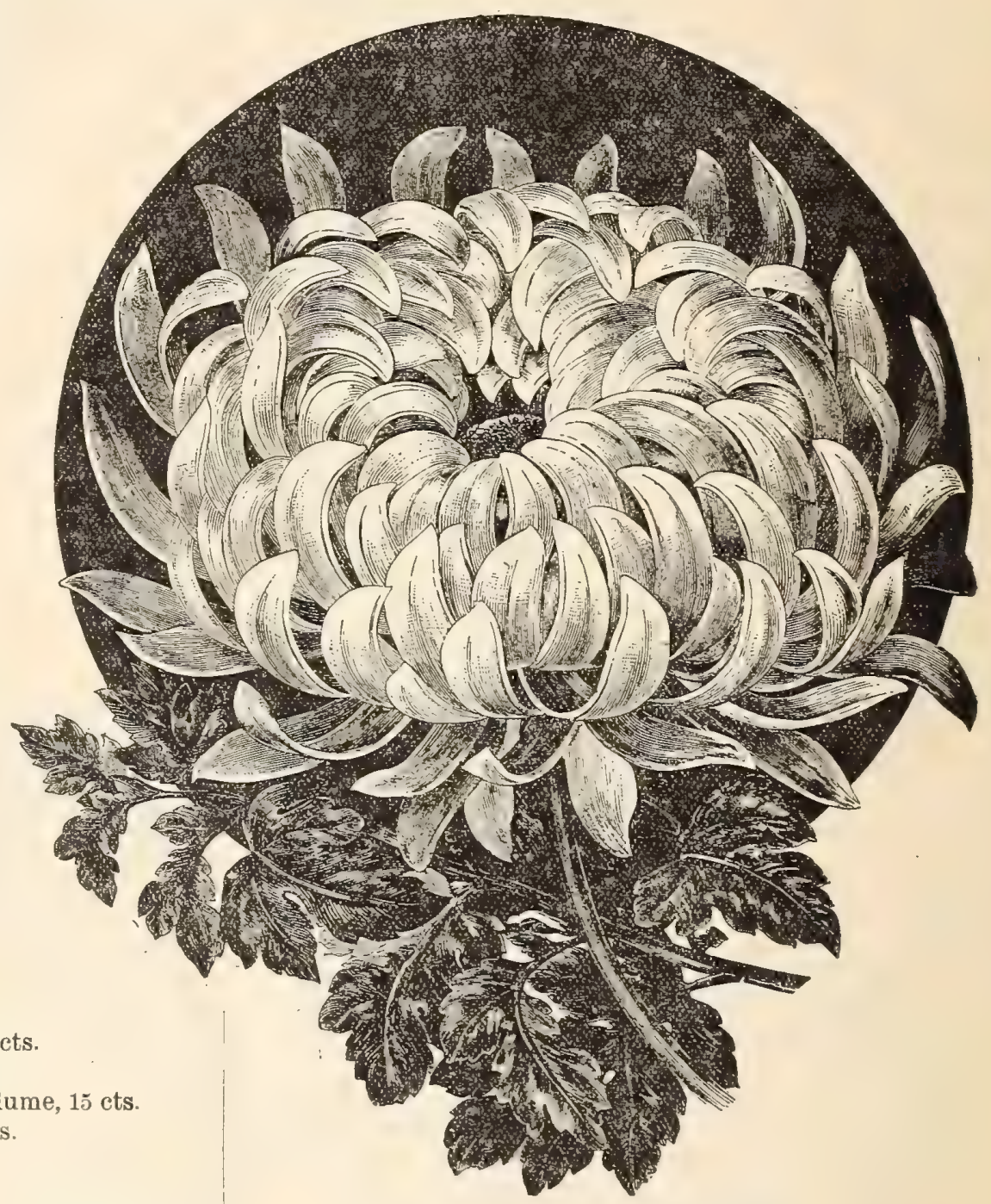

CALADIUMS.

VERY handsome. almost indispensable plants for summer decoration. Culture very simple, the bulbous roots remaining dormant all winter, to start again with little or no trouble the following spring.

ESCULENTUM - The variety so useful and so popular for subtropical beds on the lawn; also a good vase plant. Each, 25 cts.; per doz., $\$ 2.50$.

FANCY SORTS-An excellent assortment of the most distinct kinds. Each, 30 ets.; per doz., $\$ 3.00$.

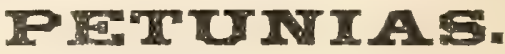

We offer a large assortment. Mixed, all colors, each, 10 ets.; per doz., $\$ 1.00$.

DOUBLE WHITE, Mrs. G. Dawson Coleman - A variety not yet equaled among the double white varieties yet introduced. The flowers are very large and full, and are borne in great abundance.

Price, each, 15 cts. 


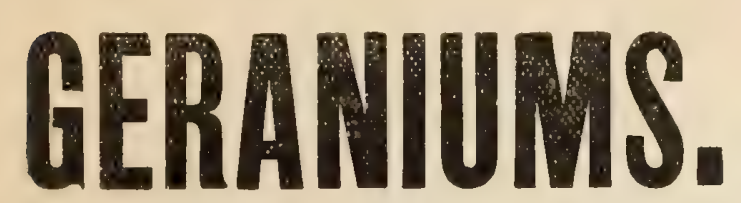

$\Lambda \mathrm{S}$ usual, we list but a few of the very best varieties of Geraniums, which we have carefully selected from the large assortment of kinds we always grow. These we offer from experience and careful observation we know to be the best for general purposes in cultivation. Having selected them we have grown them in quantities likely to be sufficient to supply every demand. As the season advances, however, it is possible we may run out of some kinds. In the event of that we could probably, if our customers will signify their approval, substitute a similar one from among the many varieties we do not list, and which are really excellent.

\section{SINGLE VARIETIES.}

BRIDAL BOUQUET - White, delicately shaded with pink.

CLEMENCE BOUTARD - Large trusses, white shaded with pink.

RALPH-Dark crimson, shaded amaranth.

SAM SLOAN-Deep scarlet, very large trusses.

QUEEN OF THE WEST-Orange scarlet, a superior variety.

\section{DOUBLE VARIETIES.}

B. K. BLISS-Scarlet, a great favorite.

BRUANT-Rich vermilion; very large full trusses; an excellent variety.

EMILE LEMOINE-Deep crimson; one of the best EMERSON-Salmon, an old favorite.

ERNEST LAUTH-Scarlet, shaded amaranth.

HENRY CANNELL-Scarlet, a very free bloomer; very superior.

JENNIE HAMILTON-Pink, shaded currant redi

LE CYGNE-Pure white.

LA FAVORITE-Pure white, large trusses.

MAY WAYTE-Crimsori.

PRES. LEON SLMON-Searlet, very fine.

QUEEN OF THE FAIRIES-Flesh color, a very free, bloomer, large trusses,

ROBERT SPARKS--Scarlet, very good.

S. A. NUT-Rich crimson.

\begin{tabular}{|c|c|c|c|}
\hline \multicolumn{2}{|c|}{ PRIOES. } & \\
\hline 1st size ....... & $\begin{array}{l}\text { Fach. } \\
10 \mathrm{c}\end{array}$ & $\begin{array}{c}\text { Per doz. } \\
\$ 1.00\end{array}$ & $\begin{array}{l}\text { Per } 100 . \\
\$ 6.00\end{array}$ \\
\hline $2 d$ size......................... & $15 \mathrm{c}$ & 1.50 & 1000 \\
\hline 3d size. . . . . . . . . . . . . . . . & $20 \mathrm{c}$ & 2.00 & 14.00 \\
\hline 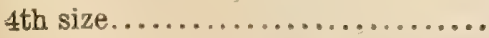 & $25 \mathrm{c}$ & 2.50 & 18.00 \\
\hline
\end{tabular}

The quotations per hundred are made with the understanding that the selection is left to us-color being specified by purchaser if desired.

\section{VARIEGATED GERANIUMS.}

BRONZES-Golden foliage, with heavy chocolate zone; in variety.

CRYSTAL PALACE GEM-Dark green center, bordered with broad band of yellow.

MRS. PARKER-Filiage edged with white; flowers double, delicate pink.

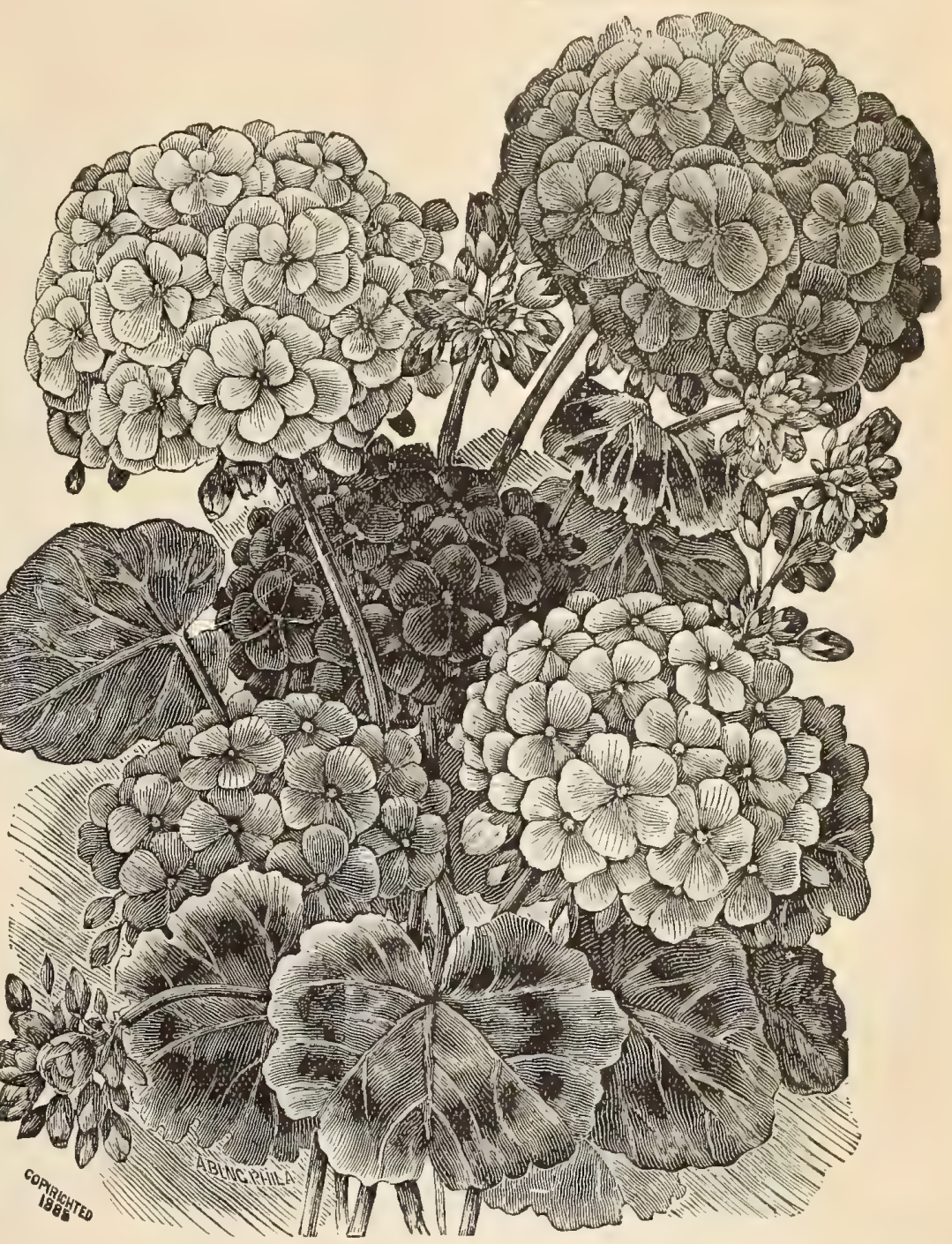

HAPPY THOUGHT--Dark green border, with golden yellow center.

MADAM SALLEROI-A very distinct variety. Center of leaf a deep olive green, with broad margins of pure white. Habit of plant dwarf and compact, grows evenly and rap. idly. The leading variety for ribbon borders or edges of beds.

MOUNTAIN OF SNoW-Dark green, bordered with a deep band of pure white.

FREAK OF NATURE-A beautiful and very desirable variety. Price, each, 10 cts ; per doz., $\$ 1.00$. SWEET SCENTED.

NUTMEG-Small, round, green leaf, very fragrant.

ROSE-Very sweet, and useful for arranging with cut flowers. SHRUBLAND PET-Fragrant and producing a great quantity of carmine flowers.

PEPPERMINT-Has a decided peppermint fragrance. Each, 10 cts. to 25 cts.

\section{IYY-LEAF VARIETIES.}

Of drooping habit, having thick, glossy leaves, similar in shape to the Ivy. They are all well adapted for vases or hanging baskets, and are very free flowering.

We have an assortment of the leading varieties, having flowers of various colors-white, pink, rose, lilac and carmine. Price, each, 10 cts ; per doz., $\$ 1.00$. 
NEW VARIEGATED GROUND IVY. (Nepeta Clechoma.)

AVERYBODY is familiar with the common green leaved If Ground Ivy, so useful for many purposes. This new variety is a variegated form of it, equally hardy, vigorous and rapid in growth, but superior because of the great beauty of foliage-sweet scented too-which is very prettily marked with white on a ground of bright green. For vases, hanging baskets and such like it is especially adapted, and is scarcely equaled by any other plant of its habit that we know of. For cemetery use for the covering of graves it is very useful and very appropriate, and we think no doubt will soon be extensively used for that purpose. Price each $10 \mathrm{cts}$.

\section{HYDRANGEAS.}

"RED BRANCHED"-New-This new Hydrangea is declared by the introducers to be the best of the Hortensis class ever produced. The trusses are larger and brighter than those of Otaska, and it produces bloom in great profusion. Price, each, 75 cts.

NEW DOUBLE PINK (H. Stellata Rubra Plena)-This is a valuable acquisition. The flowers are perfectly double and are a beautiful rosy-red in color. It is a singularly beautiful object when in full bloom. As hardy as other Japan sorts. Price, each, 50 cts.

NEW WHITE FRINGED (H. Stellata Fimbriata)-A very handsome variety, having immense trusses of pure white flowers, fringed, and having a spot in the center of crimson. The plant attains a height and breadth of three to four feet. It is a great improvement on the old white "Thomas Hogg," being better and even hardier. Price, each, $50 \mathrm{cts}$. HORTENSIS-An old favorite. Flowers pink, shading to purple. Each, 20 cts. to $\$ 1.00$.

THOMAS HOGG-A good variety, almost pure white. Each 20 cts. to $\$ 1.00$.

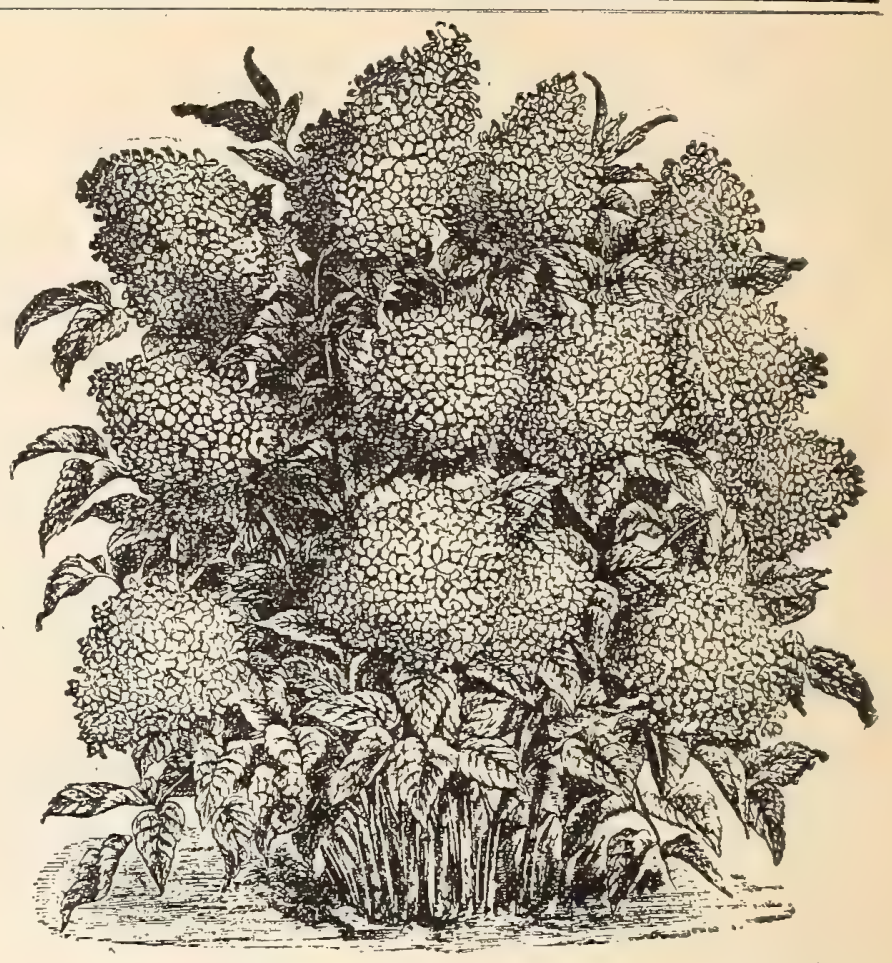

HYDRANGEAB-PANICOLATA GRANDIFLORA,

OTASKA-Very large pink flowers and fine glossy leaves. Each 20 cts. to $\$ 1.00$.

PANICULATA GRANDIFLORA-Pre-eminently the grandest of all the flowering hardy shrubs. It is perfectly hardy, requiring no protection whatever. The accompanying cut gives a very accurate representation of it when in full bloom. It begins to flower early in summer and continues until late in fall. Planted singly or in groups it has a charming effect. Each, 25 to 50 cts. Extra large plants, \$1.50.

\section{IAIEITIA BICDTOR.}

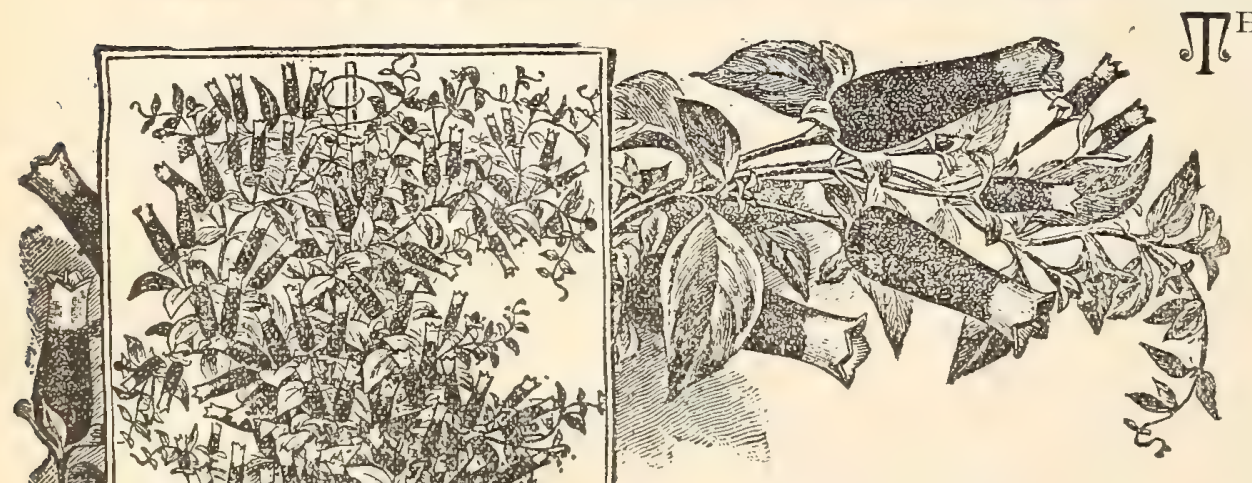

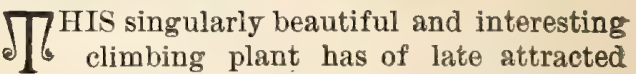
considerable attention, as well it may, for it is indeed a very handsome object. Trained on a trellis, rafter or pillar, it presents a striking appearance, never failing to immediately arrest attention. As a house plant it is very useful and very interesting, and is easily managed. The flowers of the variety named are tubular and about an inch or a little more in length; bright searlet at the lower portion, and yellow towards the apex of the tube. The flowers are produced in great profusion. Usually the plant makes a rapid growth, and it becomes necessary to resort to pruning to keep it in form. It should find a place in every collection of plants. Price, $20 \mathrm{cts}$. each; $\$ 2.00$ per doz.

\section{BLUE MOON FLOWER-Ipomœa Learii.)}

T OVERS of plants were very much interested in the Moon Flower when it $\int$ was first introduced, and many thousands of this singular plant were sold ly interesting because it is possessed of a flower which is a beautiful blue in. color. When grown alongside of the white one the contrast produces a most charming effect. Trained on a trellis if grown in a pot, or up a pillar, or on the back wall of the greenhouse, it is a most attractive object. Price, 15 cts. each: $\$ 150$ per doz. 


\section{PATIMS.}

THIs family of plants has a peculiar fascination for even the most unobserving. It is a remarkable fact that people who will daily pass by the most beautiful and sweetest scented flowers without apparently noticing them, are invariably arrested by a sight of almost any of the Palm family, and they stand to admire them. The genus is certainly exceedingly popular, and well it may be, for it numbers among its species some of the most useful plants for general decorative purposes in all the long list of ornamental plants. For conservatory adornment they stand prominently foremost, and for parlor decoration they are without an equal, for, contrary to what many people suppose, they are not only capable of being grown in the parlor but they are, indeed, very easily managed and invariably succeed well if only treated with ordinary care. Some are, of course, better adapted than others for that purpose, but fortunately the very nicest are among that number. We enumerate a few, and these are very popular and in great demand.

ARECA LUTESCENS-Slender, plume-like leaves; very handsome, very valuable as a houseplant. Each, 50 cts. to $\$ 3.00$.

BRAHEA FILAMENTOSA-Robust fan-shaped leaves; erect in habit. Each, $\$ 2.00$ to $\$ 5.00$. CORYPHA AUSTRALIS-Fan-shaped leaves, deeply divided; a very useful species. Each,

$\$ 1.00$ to $\$ 5.00$.

COCOS WEDDELIANA-A charming dwarf, slender species, very popular. Each, $\$ 1.00$ to $\$ 3.00$.

KENTIA BELMOREANA-Resembles Areca, but the leaves are stronger and dark green; a splendid house plant and in great demand. Each, $\$ 1.00$ to $\$ 5.00$.

LATANIA BORBONICA-A great favorite; leaves broadly fanshaped. Each, $\$ 1.00$ to $\$ 5.00$

PHOENIX DACTYLIFERA-Date Palm; a stately plant, with long graceful leaves. Each, $\$ 2.00$ to $\$ 5.00$.

SEAFORTHIA ELEGANS-A graceful and majestic Palm, very much admired. Each, $\$ 2.00$ to $\$ 5.00$. Our collection embraces a large assortment of other leading and well-known kinds. Prices on application.

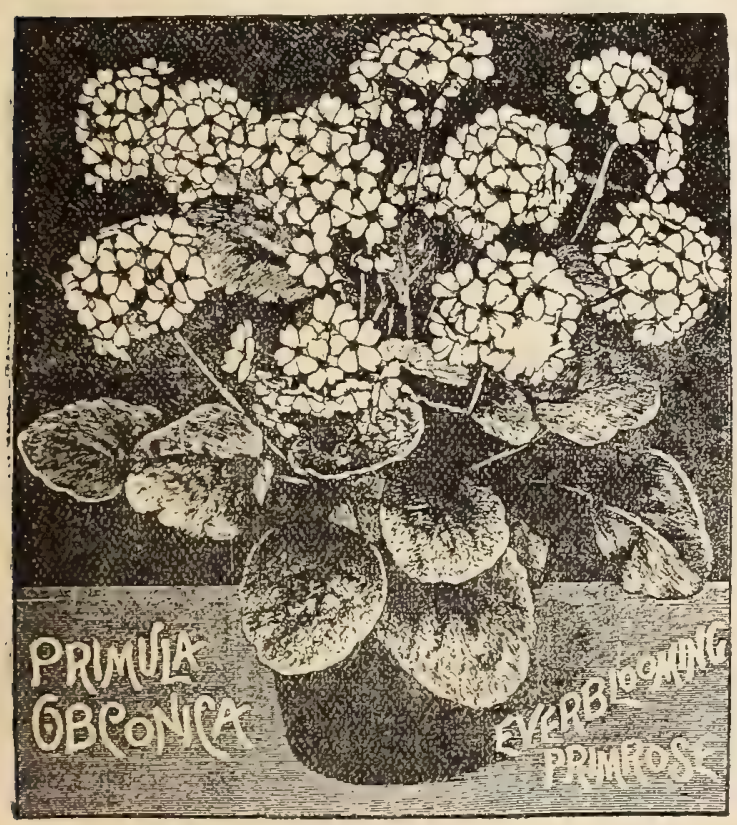

\section{PRIMIULA OBCONICA.}

TIME only proves more conclusively the correctness of the prediction we made when we first saw this lovely Primula that it was destined to attract the attention of the whole flower-loving world, and meet with universal admiration. To see it is to admire it, and the longer one grows it the better he likes it. For house or greenhouse decoration it ranks among the foremost for beauty, usefulness and extreme ease of culture. As a bloomer it has few equals, for flowers may be picked from it all the year round, although it produces most profusely during the winter months. The color of the flower is a beautiful pale lilac, at times almost pure white. A long, light, graceful but wiry stem supports the flowers. Propagation is effected at any season of the year by division of the plant, and a large stock may speedily be obtained.

Price 25 cts. to $\$ 1.00$ each.

\section{CEXIREST PRIMTUIAE.}

Double White. A very much admired win t e r - blooming species. Price, each, 25 to 50 cts.

Single, all colors. Very fine varieties Strong plants, 25 to 35 cts.

\section{PANCRATIUM CARRIBBAEUM-SPIDER LILY.}

$\Lambda$ VERY beautiful, attractive and very interesting bulbous plant, adA mirably adapted for house culture, and a great acquisition in the convery fragant, spider-like blossoms. Price, each, 20 cts. ; 3 for 50 cts.

\section{PHIOX-PERENNIAL.}

$\mathrm{V}$

ERY useful plants, both for the adornment of the flower garden or lawn, and for supplying cut flowers. The plants increase rapidly in size, and give opportunity of very soon greatly increasing the stock by division of the plant at the roots. We offer a list of very fine varieties which we have no hesitancy in recommending most highly, all being really excellent. Price, each, 10 cts.; per doz., $\$ 1.00$.

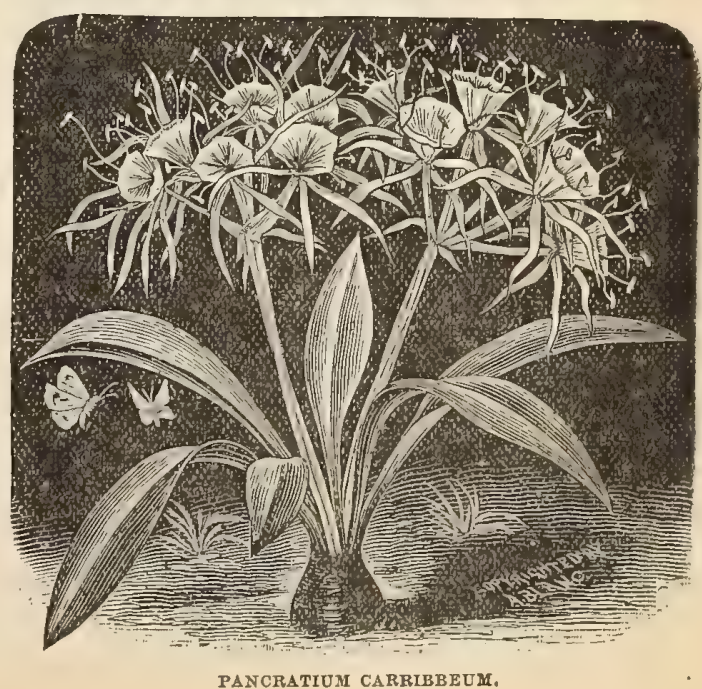




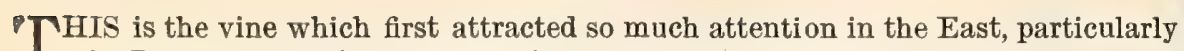
I in Boston, hence its name. It is a variety of the Virginia Creeper, but very slender and delicate-like. The plant clings very closely to wood and stone work, and rapidly attains a height of even fifty feet. The leaves are small, purp. fish green in summer, changing in fall to the most beautiful tints of crimson and orange. In our Northwestern climate the plant requires a slight protection during the first two or three winters, but subsequently it is perfectly hardy. Plant in rich.soil, and train on stakes until it is established, and has firm hold of the wall Strong plants, each, 25 cents; extra strong, each, 50 cents.

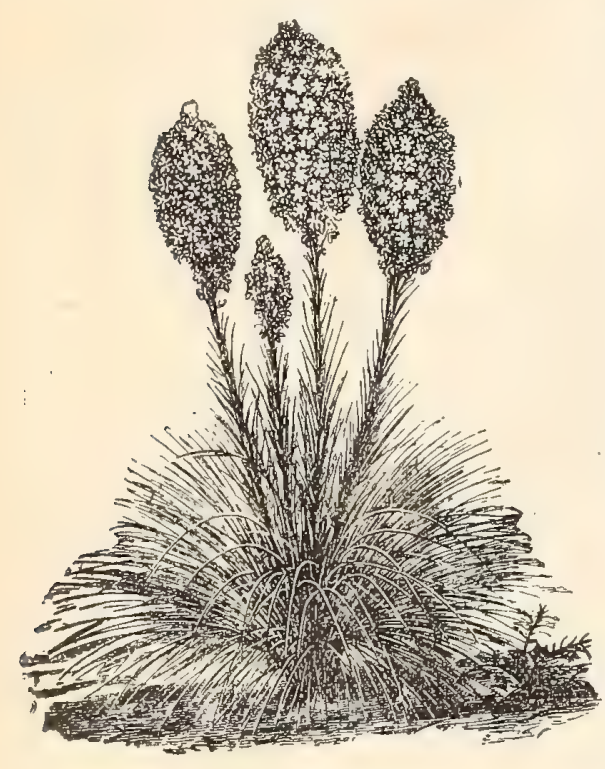

\section{AMPELOPSIS ROYALI,}

\section{(Royal Ampelopsis.)}

THIS variety of the now well-known 1 an improvement on the latter, as it is larger and stronger, at the same time being an equally good climber, clinging to the wall or other support it is trained to as firmly and closely as is the peculiar characteristic of Veitchii. In summer even, the foliage is beautifully tinted with crimson, and as autumn approaches it becomes perfectly gorgeous and continues so until very severe frost as a matter of course removes the leaves.

\section{Price, each, $25 \mathrm{cts}$. to $50 \mathrm{cts}$}
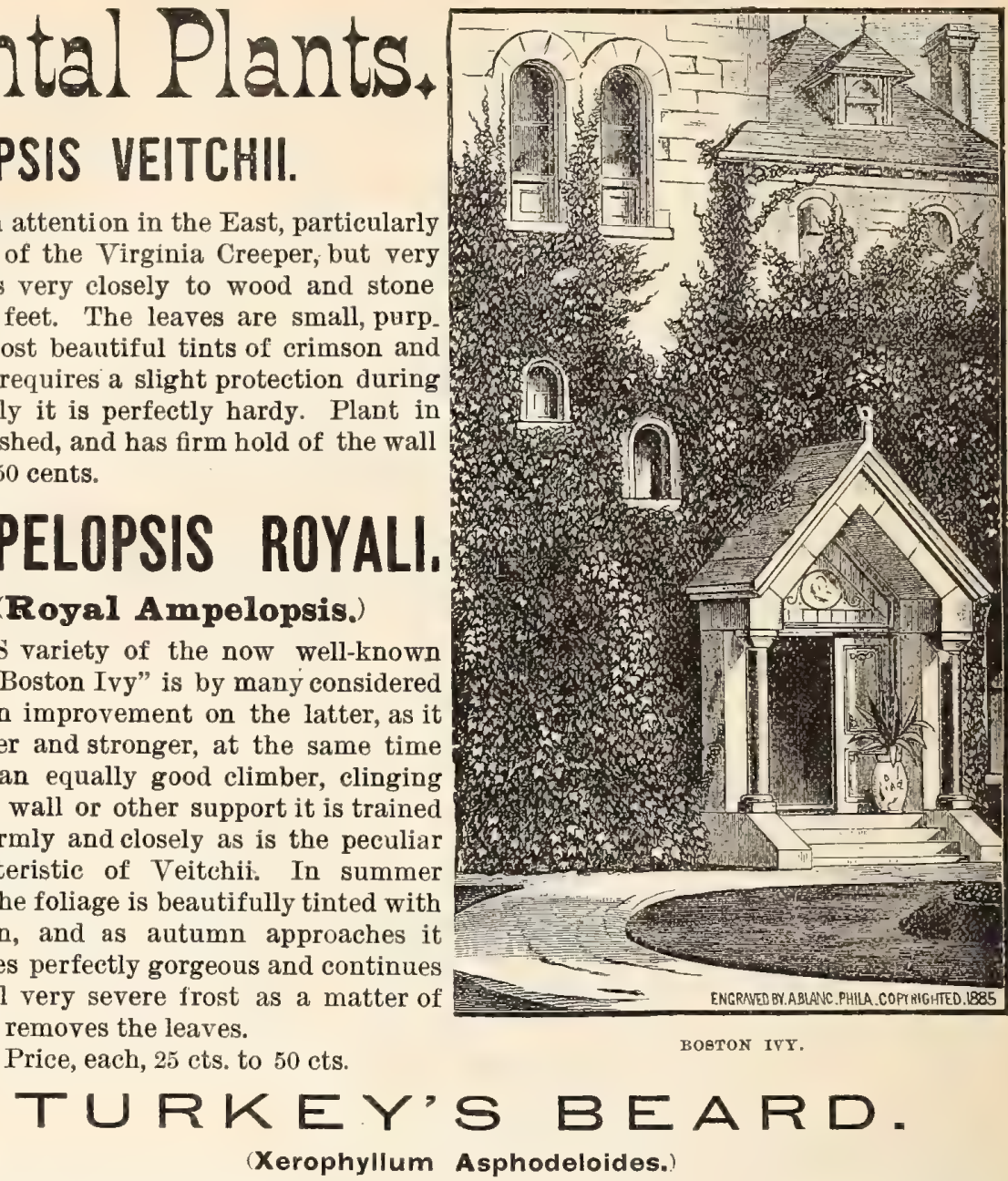

A MONG hardy plants we havenothing which attracts so much attention and excites $A$ so much wonder as the queer but beautiful plant here represented. It is perfectly bardy, and an evergreen, its leaves being long, grass-like and graceful. From a dense tuft of these rise the slender flower stems to a height of about three feet, bearing a large close raceme of creamy white blossoms. As many as ten

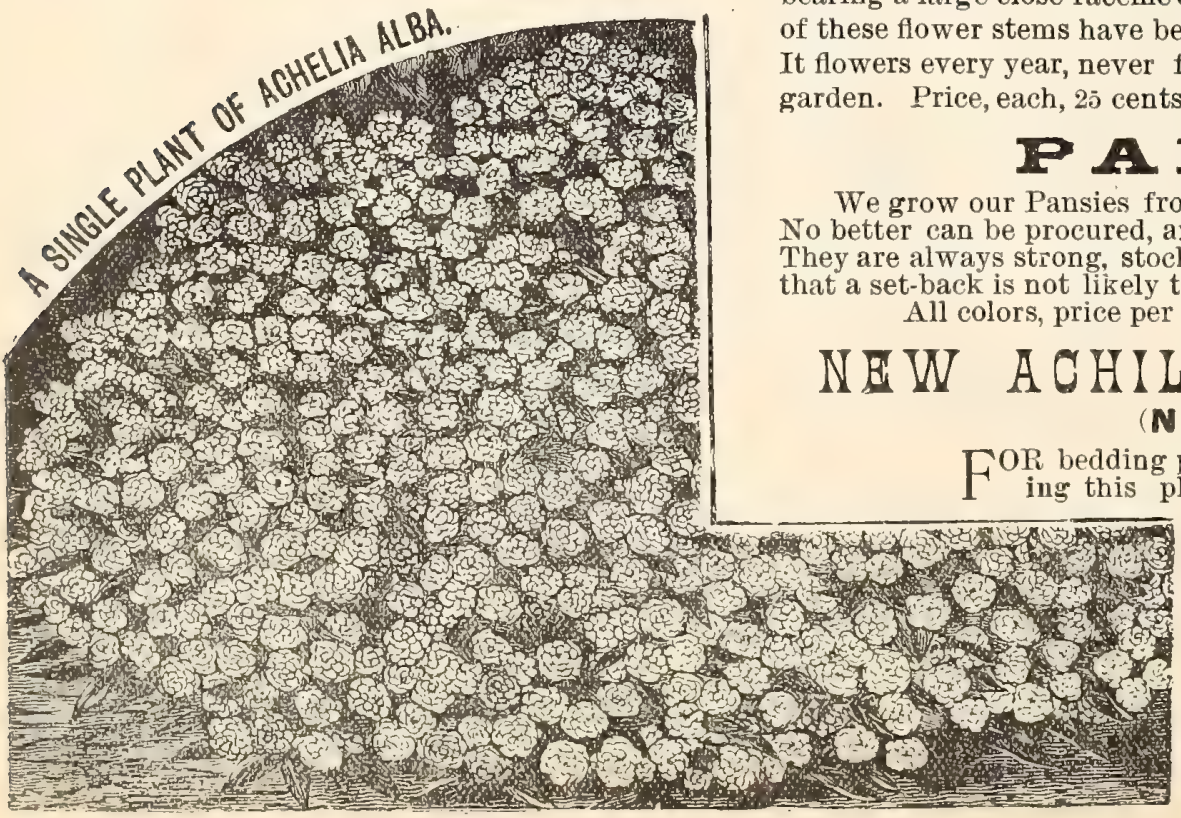
It flowers every year, never failing to blossom. It should be in every

\section{PANSIES.}

from the very finest, carefully selected seed. 列 They are always strong, stocky and hardy, being carefully managed, so All colors, price per doz., $75 \mathrm{c}$; 50 for $\$ 250 ; 100$ for $\$ 4.00$.

\section{NEW ACHILLEA "THE GEM." (New Achillea Alba fl. pl.)}

GOR bedding purposes and especially for Cemetery plantant has few, if any, equals. The accompanying engraving is a very faithful representation. The flowers are very double, are produced in such profusion are they usually, and so pure and white that the plant looks almost like a patch of snow It is very dwarf and compact, and perfectly hardy. The branches die in the fall, but new ones are again produced early in spring.

Price, each, 10 cts.; per doz., $\$ 1.00$. 


\section{CICINA TIS.}

TOR covering large spaces quickly, the Clematis stands unrivaled. They may be planted

$\mathrm{F}$ at any time. The ground should be dug deep and well manured; in fact, the ground cannot be made too rich for them. A little attention to this will amply repay you for your trouble, as the plants will grow more vigorous and consequently give a greater quantity of fine flowers.

ANDERSON HENRYI-Large pure white flowers, free bloomer, one of the best varieties in cultivation. Price, $\$ 1.00$.

ALEXANDRA-Pale reddish violet, free bloomer. Price, 75 cts.

COUNTESS OF LOVELACE-A double variety; bright bluish lilac, with white filaments and yellow anthers; sometimes produces single flowers the first season. Price, $\$ 1.00$.

COCCINEA-Scarlet; the flower looks more like a bud than a blossom and forms a striking contrast when grown side by side with other varieties. Price, 20 cts.

CRISPA-Lavender, bell-shaped flowers; very fragrant; habit robust, hardy and freeflowering. Each, 20 cts.

DUCHESS OF TECK-Pure white, with a delicate mauve bar down the center on first opening; a fine shaped variety. Price, $\$ 1.00$.

DUCHESS OF EDINBURGH-Fine double white of vigorous habit, and free bloomer; very fragrant. Price, $75 \mathrm{cts}$.

FAIR ROSAMOND-Bluish white, with an indistinct wine-red bar. Price, 75 cts. FAIRY QUEEN-Pale flesh, with striking pink bar. Price, 75 cts.

GE.Y-Deep lavender blue. Price, $75 \mathrm{cts}$.

GIPSY QUEEN-Bright, dark velvety purple. Price, 75 cts.

GRAND DUCHESS-A beautiful variety, white, flushed rose. Price, 75 cts. JACKMANNI-Deep violet purple flowers produced in masses; one of the best. Price, 7 cts,

JACKMANNI ALBA-A pure white variety of the preceding; very fine. Price, $\$ 1.00$. LADY CAROLINE NEVILL-Bluish white, mauve bars; very fine. Price, 75 cts.

LANUGINOSA CANDIDA-Tinted grayish white. Price, 75 cts.

LANUGINOSA NIVEA-Large pure white. Price, 75 cts.

LA WSUNIANA - Rosy purple, slightly marked with darker veins. Price, 75 cts.

LORD LONDESBOROUGH-Deep mauve, with a coppery-tinted, purplish-red bar. Price, $\$ 1.00$.

LORD NEVILL-Rich, dark plum, large and well formed, stamens light with dark anthers, edgings of sepals finely trimmed; distinct from anything yet offered. Price, $\$ 1.00$.

MAD. VAN HOUTTE-White, extra fine. Price, 75 cts.

MAD. GRANGE-Crimson violet, tinted with red in the center; most distinct and beautiful. Price, 75 cts.

MRS. GEORGE JACKMAN-Satiny white, with a creamy bar. This variety often flowers in the young wood, giving it more the character of a perpetual bloomer. One of the best of the early flowering whites. Price, 75 cts.

MRS. G. M. INNES-Lavender blue; double. Price, $\$ 1.00$.

OTHELLO -..Dark velvety purple. Price, 75 cts.

REINE BLANCHE-Light mauve with lighter bar. Price, $75 \mathrm{cts}$.

ROBERT HANBURY-Bluish lilac, flushed at edge with red. Price, 75 cts.

RUBELLA-Velvety claret purple, distinct and very free blooming. Price, 75 cts.

STAR OF INDIA-Reddish violet purple with red bars, distinct and effective. Price, 75 cts.

STANDISHII-Light mauve purple. Price, $75 \mathrm{cts}$.

SYMEIANA-Pale mauve or bluish lavender, large flowers. Price, $75 \mathrm{cts}$.

WM. KENNETT-Deep shining lavender, very large. Price, 75c.

VITICELLA RUBRA GRANDIFLORA - Bright claret-red. Price, 75 cts.

FELUTINA PURPUREA-Blackish mulberry; distinct. Price, $\$ 1.00$.

Strong, 3-year old plants, 12 good and distinct kinds, our selection, for $\$ 7.50$.

\section{HOLLYHOCK.}

UR varieties of this old favorite are from carefully selected seed of the very best varieties, full and double, all colors. Price, each, 10 cts.; per doz, $\$ 1.00$

Strong Roots from open ground, 25 cts each; per doz., \$2.50.

\section{NEW DWARE SUNELOWER.}

(Helianthus Multiflorus Plenus.)

THIS year we are fully prepared to supply every demand for this grand plant. We have propagated a large stock of of it, anticipating a repetition of last year's demand, which was large, exceeding even our expectations. We are confident that the popularity of this plant will never cease; it is so beautiful and so useful for the adornment of the lawn, or for supplying cut flowers. A single plant produces armfuls of flowers, and these last a long time when cut. A single specimen on the lawn is very effective, but a bed of it is gorgeous. It attains a height of three feet, is robust and compact in habit; is easily propagated by division of the plant, and is perfectly hardy. Flowers very double and perfect in form; a rich golden yellow in color. Price, each, 10 cents.; per doz., $\$ 1.00$.

I Large, strong plants, 25 cents each. 


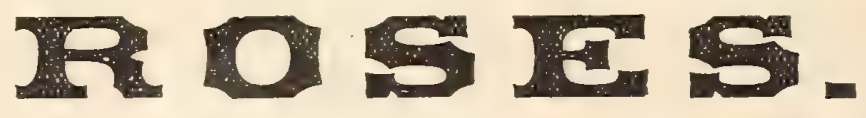

HYBRID PERPETUALS.

Out of the almost endless list of Hybrid Roses in cultivation we have selected from year to year those we find the best, quality, general desirability and adaptability to our climate being taken into consideration. From our stock we have picked out what we consider the best twelve and offer them with the full assurance that they cannot fail to give satisfaction. The plants are large and strong and very healthy.

Anna de Diesbach-Clear rose, large.

Bertha Baron-Delicate rose, shaded white, very large.

Climbing Jules Margottin-Bright cherry.

Climbing Victor Verdier-Rosy carmine, a very fine rose.

De Andry-Dark bright red, very large.

Gen. Jacqueminot-Brilliant velvety red, vigorous habit and free bloomer.

Large strong plants in 4 inch pots. Each 35 cts.; per doz., \$3.50; by express only.

La Reine-Rosy pink, edged with lilac, very large.

Madam Trotter-Brilliant red, vigorous habit.

Magna Charta-Bright pink suffused with carmine, very large, a grand variety.

Prince Camille de Rohan-Pink, velvety, dark crimson.

Paul Neron-Deep rose; large flowers.

Victor Verdier-Rosy carmine.

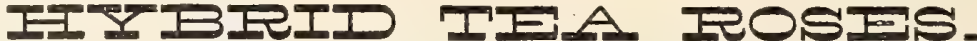

Duchess of Albany-A charming new Rose, a grand rival of | Wm. Francis Bennett-Rich glowing crimson; a superb variLa France, which it resembles, but the color is a much richer pink.

Price, each, 25 cts

American Beauty - Very large, very fragrant, brilliant crimson, free bloomer. Each, 25 cts.

\section{IIOSS ROSFE.}

This class of Roses is even more hardy than the Hybrid Perpetuals but should be treated about the same.

Capt. John Ingram-Crimson.

Mad. Blanche Moreau-Fine new variety; pure white.

Perpetual White-Blooming in clusters; double.

Salet-Bright rose, blush edges, large and full. Large strong plants, each, 40 cts ; per doz., $\$ 4.00$. By express only.

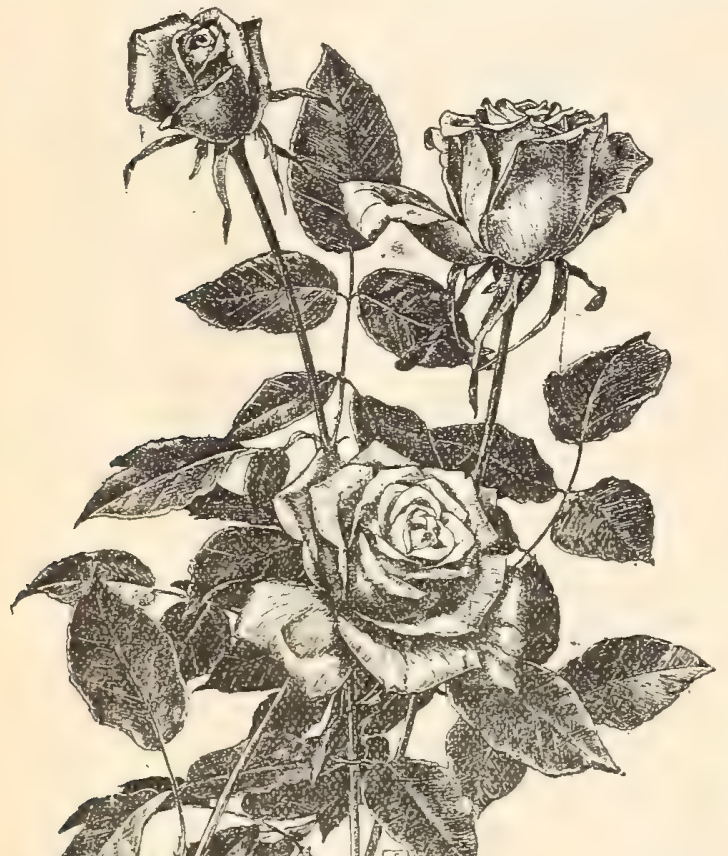

\section{TEA ROSE "Y ABAN."}

In vigor of plant, length and strength of flower stem, size, form, color and perfume of bloom it is perfect, and quite distinct from any previous introduction. The color is a rich carmine pink, just what we have been in quest of in the Tea Family.

Price, each, 25 cts. ; per doz., $\$ 2.50$.

GENERAI COLLECTION OF EVERBLOOMING ROSES.

Adam-Carmine pink, extra large; very double.

Agrippina-Brilliant fiery red, very double; profuse bloomer.

Anne Marie de Montravel-Polyantha Rose; pure white; very free bloomer.

Bon Silene-Deep rose color, very fine.

Catherine Mermet-Fiesh colored; very fine large buds.

Duchess de Brabant-Soft rosy flesh, changing to deep rose.

Duchess of Ediuburgh-Brilliant crimson. shaded with maroon.

Glorie de Dijon-Rich creamy yellow, shaded with amber; very double.

Hermosa-Beautiful clear rose; constant bloomer.

La France-Fine pink.

Madam Hoste-One of the finest Roses ever introduced. Color white, shaded with delicate canary yellow. Each, 15 cts., per doz., \$1.50.

Madam Bravy--Rich creamy white with blush center.

Madam de Watteville-Called the "Tulip Rose." because of its resemblance to some of the most beautifully shaded flowers among Tulips. It is shaded with pink, rose and creamy white; very handsome.

Malmaison-Flesh color; very fragrant.

Marechal Niel-Deep golden yellow; buds of immense size.

Marie Guillot-White, fringed with lemon; very fine

Meteor-A new rose of a remarkable deep velvety crimson, a constant bloomer, flowering especially well in summer, even in the hottest weather. Each 15 cts.; per doz., $\$ 1.50$.

Niplietos-Large, pointed, snow-white buds; very fine.

Papa Gontier-Deep pink

Perle des Jardins-Clear, golden yellow; extra fine

oueen of Bedders-Crimson; an excellent bedder, profuse bloomer.

Safrano-Bright apricot yellow; very profuse bloomer.

Snnset-This is a sport from Perle des Jardins; vigorous grower; flowers a beautiful shade of apricot.

Sonvenir de Wootton (New)-A superb variety, having few equals. The flower is very large and full, and of a rich crimson color. Each 15 ets.; per doz., \$1.0̃0.

Sonvenir d'un Ami-Light Pink.

The Bride-A sport from Catherine Mermet, and is a counterpart of that fine variety, excepting in color, which is pure white. 10 cts.; per doz., $\$ 1.00$.

HARDY PERSIAN YELLOW ROSE-Deep Golden Yellow, each 50 cts.

\section{HARTY CLIMBING ROSES.}

Valnable fur training un trelijes, fences snd piazzas; when once establiebed no climber 'cires greater satiefaction. Terr little care need be given them for the 


\section{Currie Bros.' Hortieultural Guide. _ — C SUMMER FLOWERING BULBS AND ROOTS. GIATIOLI.}

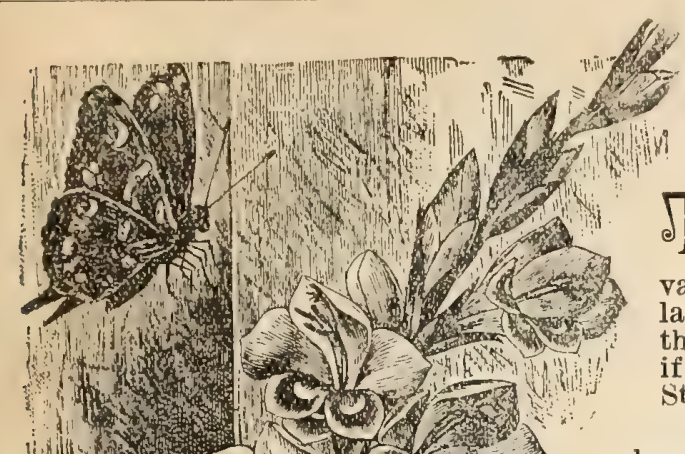

7 HIS family of plants is well worthy of the attention it receives, and a few d 6 of them, at least, should find a place in every garden, however small. Their stately, magnificent flowers are highly ornamental in the garden, and invaluable when eut and placed in vases in the parlor, where they will invariably last for a week at least. No plant is more easy of culture. Plant the bulbs from the first of May to middle of June, setting them from 6 to 9 inches apart, or more if desirable, and 4 inches deep. Keep the ground cultivated and well watered. Stake the plants when about a foot high.

NEW CLADIOLUS-(Snow White.)-A most magnificent variety, of fine substance, lasting a long time. Each, 25 ets.; per doz., \$2.50.

COLVILLI ALBA-(The Bride)-Hardy, pure white. Early, requiring only a slight covering of straw or leaves to protect it from the severest frosts. 5 cts. each; 50 cts. per dozen.

MIXED CLADIOLI-The following list of mixed bulbs includes many of the very cholcest and most desirable varieties in cultivation.

Very tine varieties of various shades of red, per doz., 25 cts.; $\$ 1.75$ per 100 .

Very fine varieties of light colors and white, per doz., 60 cts.; $\$ 3.75$ per 100 .

Very fine varieties of rose colors, per doz, 50 cts.; $\$ 3.25$ per 100.

Very fine varieties of yellow, per doz., 40 cts.; $\$ 2.75$ per 100.

For 35 cents we will mail to any address one dozen extra choice mixed assorted colors; by express; 100 for $\$ 2.50$.

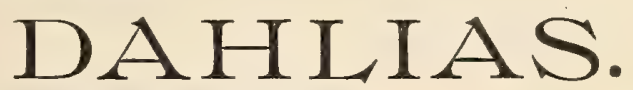

BEST STANDARD DOUBLE SORTS.

AMAZON-Yellow, scarlet edge.

BOB RIDLEY -Deep red

DUKE DE MALAKOF-Bright acarlet.

ELIJAH NIEVES-

JAUNE DE PASSEY-Yellow.

LADIES' JEWLL-Blush, tipped with white and shaded rose.

MADAM SPARRY - White, tipped old gold.

MRS. SIGOURNEY-Light blnsh, edged pur-

PkINCE OF WALES-Dark purple.

PRINCE DE BOGRINE-Pink and white,

edge purple.
SAMUEL-Dark maroon.

SHEIK-Fine Bcarlet

TRIUMPH DE ROBEAUX-Amber, shaded Tose.

ZELMIR A - Pink and crimson stripes, sports

CRIMSON AND PURPLE-

CRIMSON AND WHITE-

GLADIOLI.

TIGRIDIA.

CONCHIFLORA-Yellow and orange, with dark

8pots, each, $5 c$; per doz., 50c.
PAVONA-Scarlet, with crimson spots. Each 5c; per doz.. 50c.

GRANDIFLORA ALBA-White, 10c each ; per doz., $\$ 1.00$.

\section{THE GIANT FAIRY LILY.}

\section{(Cooperia Drummondi.)}

A very pretty, very useful and exceedingly in terestluy bulbous plant, belonging to the Amaryllis family. The fiowers are bell-shaped or lilylike, white and borne on stems ten to fiftern inches long. The balbs should be planted in spring either in pots or in the open ground. Early in summer they will begin to bloom and will continue to flower the greater part of the summer. In fall the bulbs should be taken up and treated the same as those of the Gladiolus. It is well entitled to a place in every garden.

Price, each, 10 cts.; per doz., $\$ 1.00$.

\section{APIOS TUBEROSA.}

(Tuberous-rooted Wistaria.)

A popular hardy climber, resembling the Wigtaria. It produces in grest abundance large clusters of delightfully fragrant flowers of a rich purple color. The plant will bloom, the first season after planting the truber.

CRIMSON TIPPED-

SCAKLET-

YELLOWour selection, $\$ 1.75$ per dozen.

Mixed, all colors, each, 15c.; per doz., $\$ 1.00$.

\section{LILIPUT OR BOUQUET DAHLIAS.}

LITTLE DORRIT - Dark purple, finely yuilled.

LITTLE SCARLET-Fine form.

Dry roots, each, 20c.; per doz., $\$ 2.00$.

Pot plants of all kinds ready April 1st,

each, 15c.; per doz., our selection, $\$ 1.50$.

Mixed, all kinde large roots, each, 15c.; per doz., \$1.50.

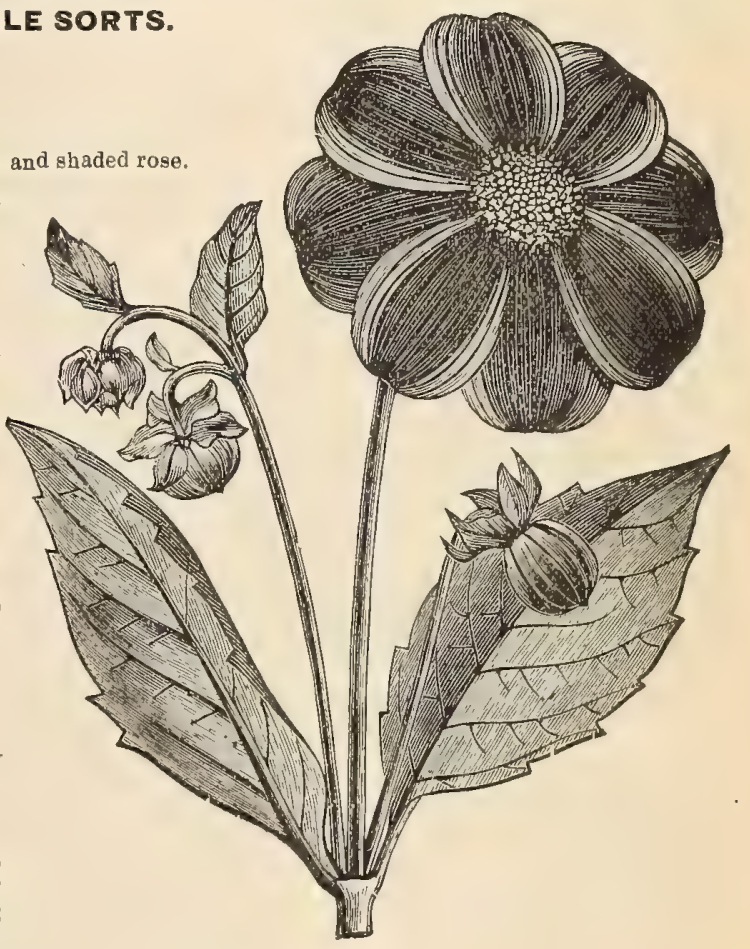

SINGLE DAHLIAS.

Aside from the fact that the Single Dahlias are very beautifnl and as varied in color as the double varieties, the flowers are especially well adapted for cutting for toral arrangements, vases, etc., they are so light and graceful and are borne on long and sufficiently sill all summer and fall. Our stock is raised from ceed gathered from the very finest varieties of all colors. dance all summer and fall. Our stock is raied from teed gathered from
Price, each, $10 \mathrm{cts}$; per doz., $\$ 1.00$.

\section{ZEPHYRANTHUS.}

Very interesting free blooming plants, resembling the Amaryllis in their style of growth and flower ALBA-Grows about ten inches bigh; flowers pure; white, one on each stalk. Each, 5 cts.; per doz........ 50

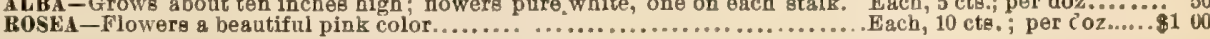

TUBEROSES. (Double.)

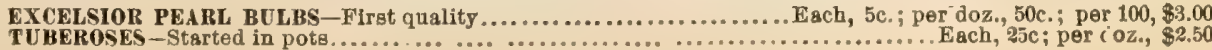




\section{8 -}

\section{ABRIDGED LIST OF PLANTS.}

THE following useful plants are so well known that we feel it is unnecessary to occupy any more of our limited space than is sufficient to simply mention them. We have a large stock of all in perfect health, and, considering their size, they are very cheap at the prices.

Abutilons-White, yellow, red and striped......... 10 to $25 \mathrm{c}$

Achyranthes-In variety. Per doz., $\$ 1.00 \ldots$

Acalypha-Foliage Plant ........................... to $25 \mathrm{c}$

Ageratum-Blue and White. Per doz., $\$ 1.00 \ldots \ldots \ldots \ldots 10 \mathrm{c}$

Alyssum - Single and double. Per doz., $\$ 1.00 \ldots . . . . . .10$

Alternantheras-Crimson, red, yellow. Per doz., $\$ 1.00$ per $100, \$ 6.00$.

Asters-In variety. Per doz, 25c; by mail, 10c doz. extra. $5 \mathrm{c}$

Anthericum Vitatum and Picturatum........... 25c

Bouvardia--For winter bloom, in variety, per doz., $\$ 1.00$. $10 \mathrm{c}$

Balsam-Various colors Per doz., 25e; by mail, 10e per dozen extra.

Centaurea -Dusty Miller, Per doz., \$1.00........... 10c

Caster Oil Bean-In variety................... 25 c

Clerodendron Balfouri-Fine Greenhouse climber.... 25e

Celosia Cristata-Prize varieties. Per doz., $\$ 1.00 \ldots \ldots .10 \mathrm{c}$

Cinnamon Vine-Strong tubers. Per doz., $\$ 1.00 \ldots \ldots .10 \mathrm{c}$

Cobaea Scandens-Rapid climber................ 25e

Crotons-Handsome hot-house plants. One doz. distinct kinds, $\$$ o. 00 .

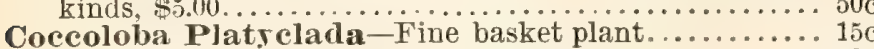

Cypress Vine-For hanging baskets.............. 10c

Cuphea Platycentra and Hyssopifolia........... 25c

Dracaenas - In variety.......................25 c to $\$ 3.00$

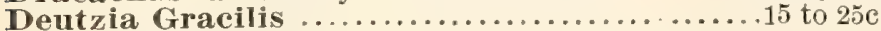

Echeveria Secunda Glauca-Hen and Chickens. Per doz. $\$ 1,00$

Eucharis Amazonica.

Eupatoriums - In variety, winter blooming plants....

Feverfews-Golden. Per doz, $50 \mathrm{c}$

Feverfew Little Gem-A great improvement on the old kinds. Both for bedding purposes and for supplying cut flowers. Per doz, $75 \mathrm{c}$.

Ficus Elasticus-Rubber plant .............. $\$ 0$ c to $\$ 1.00$

Ficus Repens-Creeping Fig...................... 15e

Farfugium Grande-Handsome foliage plant........ 15c

Freesia Refracta Alba-Very sweet scented.

Pelargoniums-In variety

G!oxiuia-Choice kinds, all colors

German Ivy-For vases.................

Hibiscus-In variety.

Heliotrope--In variety

Ivies-English.

\section{PLANTS SUITABLE FOR VASES AND HANGING BASKETS.}

FOLLOWING we list the various plants generally used and best adapted for filling ra res and hanging baskets. We bave them in various sizes, which are indicated by the difference in the prices: small sizes are intended for and are most auitable for ordinasy
wyaste of time, considering our short summers, to use small plants to fill vases of the ordinary size.

UPIEICIT PLANTS.

\begin{abstract}
ACHYRANTHES - Colored foliage
ATALYPHA-CC

AGERATUY

ALOYSIA-(Lemon Verbena)

ANTHERICUM VITATUM VAR

BEGONIAS- In var
\end{abstract}

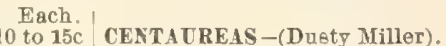

10 to $15 \mathrm{C}$
CENTACREAS - (Duety Mill
25 to $50 \mathrm{c}$ CALADIUM ESCULENTEM

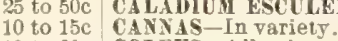

COLEUS-All color

CYPERUS - (Umbrella plant)

CUPHEA PI TreTTR1-Cigar plant).
Isolepis Gracilis-For vases............... Each.

mpatiens Sultani-Handsome house plant...........15e

Kenilworth Tyy-For vases and baskets............. $25 \mathrm{c}$

Lantana-Various colors............... 10

Lemon Verbena............................... $10 \mathrm{c}$

Gibonia Penrohiensis........................ $10 \mathrm{e}$

Cobelia-All kinds. Per doz $\$ 100$.

. Vine for vases, white............ 10c

Maderia Vine-For vases.

Mahernia Odorata - Winter blooming plant........... 10e

Mauraudia-Flowering vine for vases.............. 10e

Mignonette-Per doz., $\$ 1.00 \ldots . .$. (anthemum Cordifolium Var-Vine for

Myosotis Palustris-Forget-me-not.....................

Myrsiphyllum Asparagoides-Smilax..............15e

Oxalis-In variety.............................. 10

thonna Crassifolia-Vine for hanging baskets....... $10 \mathrm{c}$

Plox Drummondii-All colors, Fer doz. $\$ 1.00 \ldots \ldots \ldots 10 \mathrm{c}$

Pandanus Utilis - Screw Pine .............. $\$ 1.00$ to $\$ 10.00$

Pansies-A very choice assortment. Per doz., $75 \mathrm{c} ; 50$ for

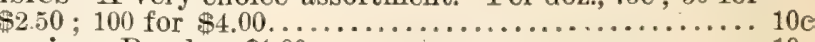

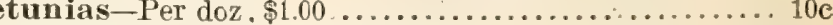

Rhododendron-Very strong plants...........\$1.00 to $\$ 3.00$

Santolina-Small, grey foliage; a valuable plant for pet bedding; dwarf. Per doz., $\$ 1.00 \ldots . . . \ldots . . . . . .10 \mathrm{c}$

Saxifraga Sarmentosa-Trailing plant for vases....... 10 $\mathrm{c}$

Stevia-Green and variegated, for winter blooming...... $10 \mathrm{c}$

Stocks-In variety, Per doz, $75 \mathrm{c}$.

Trantia - Wandering Jew..................

Verbenas-Grown from choicest seed. Per doz., 60c; 50

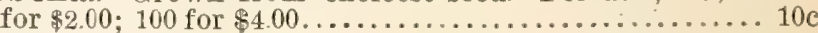

erbenas-Choice named sorts. Per doz. $75 \mathrm{c} ; 50$ for $\$ 250$.

100 for $\$ 5.00 \ldots$

Yolets-Marie Louise: Per doz, $\$ 1.00 \ldots . . . . . . . . . . .10 \mathrm{c}$

Vinca Minor-(Mrtle) for Cemeteries.

Zinuias-All colors, very choice. Per doz., $75 \mathrm{c} \ldots \ldots \ldots \ldots . . . . . . .6 \mathrm{c}$

\section{FANGING PIANTS.}

ALY SSUM-Single and double. CRASSULAS-In variety

FICUS REPENS-Creeping Fi

GERMAN IYY
KENILWORTH IVY

LOBELIA-White and blue.

LOPHOSPERMUM

MADERIA VINE

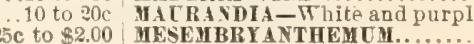

$\mathrm{Each}$

10 to $15 \mathrm{C}$ OTHONYA CRASSIFOLIA

10 to 15 PETUNIA-Single, aU color

10 to $15 \mathrm{C}$ TRADESCANTI

TRADESCANTIA

$10 \mathrm{c}$ VINCAS-Green and variegated.
Each. DRACENA 1NDIVISA - Handsome center plant, UCHSIAS-In variety HELIOTROPE HETTOPE............... PALis-For center plants

to 250 10 to $25 \mathrm{c}$ 10 to $20 \mathrm{c}$ 1.(0) to $\$ 5.00$

Each 10 to $20 \mathrm{c}$ .. $10 \mathrm{c}$
$.10 \mathrm{c}$ 10 to 200 10 to 250

\section{SEEDLING SUMMER BLOOMING PLANTS.}

gye a large assortment of summer-fowering annusls such as Asters, Phlos, Petunias, Stocks and all the leading farorites, nseful alike for lawn decoration

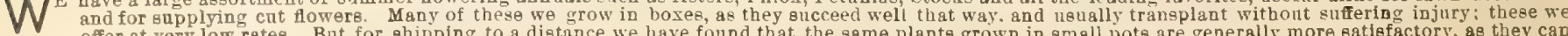
offer at very low rates. But for shipping to a distince we have found that the same plants grown in small pots are generally more satiefactory, as they can

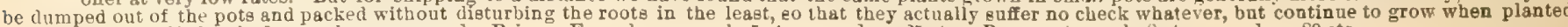
1a the garden, as if they had never been removed. Price: From boxes, each, 5 cts.; per doz., 25 cts. Prom pots, each, 8 cts.; per doz., 80 cts. 


\section{. Currip Bros.' Hortieultural Guide. \\ HARDY SHRUBS AND SMALL FRUI'TS. \\ HARDY SHRUBS AND SMALL FRUI'TS.}

\section{HARDY SHRUBS. \\ Large Strong Plants.}

Almond, Flowering-A beautiful, delicate little shrub with double red,

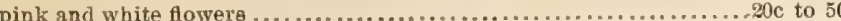
Berberry-An interesting and beantiful ahrub, with violet purple leaves

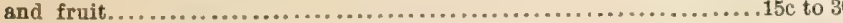
Cornus Senguines-(Red Dogwood)-Fine, hardy shrub, very conspicuous and ornamental in winter, when the bark is blazed red............25c to 50 Cornus Mascula-(Variegated Dogwood)-A heantiful shrub; fine habit Deutzla Gracilis-Flowers double white, produced on racemes four to six

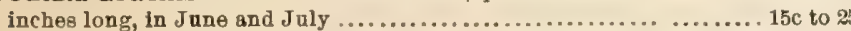
Euonymus, or Burning Bush-One of the largest growing hardy shrubs, whose chief beauty consists in its brilliant rose colored berries, which hang in clusters from the branches until mid-winter...................25c to 50 Elder, Golden-A handsome shrub, with golden-yellow foliage, and clusters of pure white flowers in June ............................20) to 40 Forsythia, or Golden Bell-Pretty shrubs, prodacing árooping yellow flowers in the early apring, before the leaves appear.

Hydranges Paniculate Grendlflora-(See descriptive page 72) $.25 \mathrm{c}$ to 50 Extra large plante.........................................\$1.50

Eoneysuckle, Upright-An old, well-known shrub, producing red, white, pink and variegated flowers in May and June. Four varieties........25 to 50 Lllac-Well known, hardy shrubs, bearing a profusion of large, showy, fragrant blossoms, white and purple ... Prunus Pissardi-One of the finest shrubs in cultivation; wood and leaf are of a rich dark purple, producing a black fruit early in the season. .25c to 50 Pyrus Japonica, or Japan Quince-One of our best summer flowering shrubs; bears a profusion of bright scarlet flowers..............25c to 50 Spirma-One of the prettiest shrubs in cultivation and of the easiest culture; their blooming extends over a period of three monthe. Flowers of almost all colors, red, white, pink, pale green and rose colored.....20 to 40 Spirzea-Aurea-Golden foliage; flowers white, very ornamental . 20c to 40 Collosa Alba-Dwarf; very free bloomers, white........20c to 40 Prunifolia - White; very desirable.....................20c to 40 Van Houtti-Rose colored; excellent.................... 20c to 40 Syringa, or Mock Orange-Well known beartiful shrubs, indiepensable in every collection, producing fragrant white flowers in June....15c to 40 Snowball-A well known farorite shrub, of large eize, with globular clusters of white flowers in June ...............................20 to 40 Symphoricarpus Racemosus-(Snowberry)-A very pretty and interesting shrub; pinkish white flowers, followed by white berries.......20c to 40 Weigela-The most valuable spreading shrub as yet introduced; producing in June and July large trumpet-shaped flowers of all shades and colors, from pure white to red -8 varieties. Each .....................20 to 40

\section{HARDY HERBACEOUS PLANTS.}

The grand old-fashioned hardy flowering plants, once so common in our gardens, but which for many years past have been quite neglected, we are pleased to see, fast making themselves popular again. The demand is increasing repidly, so that it is now safe to predict in a very few years these plante will again be the universal favorites they once were and so deservedly too. They are all attractive, many of them beautiful. They require so little care, and they are so useful for supplying quantities of cut flowers all through the summer. When once planted they may be eaid to care for themselves, as nearly all of them die down to the ground every fall, all that is necessary to do is aimply to cut away the decayed stems. In spring the plants produce new stems. Each year they increase in size, and consequently admit of division, by which means they are rapidly propagated. We list a few of the best and most popular ones, all so well-known generally that descriptions of them may be omitted since our space is very limited. Try a few of them, they are inexpensive, and no plants so well repay the cultivator for any expense or trouble he may be put to.

Achillea "The Pearl"-Flowers white, resemble a pompon Chrysan-

themum. Each, 25 cts.; per doz................................ 2.50 Achillea Tomentosa-Flowera yellow, very pretty. Each, 25c. per doz.2.50 Ajuga Preptans-Valuable for rockwork. Each, 25 cts.; per doz.......2.50 Anemone Japonica Alba-An almost indispensable perennial, flowers white. Each, 20 cts. ; per doz................................. 00 Aquilegias - In variety. Should be in every garden. Each, 25c. per doz..2.50 Campanula Pyramidalis-Bell-shaped blue flowers. Each, 20c. per doz.2.00
Campanula Grandiflora-Large bell-shaped flowers. Each, 20 ct8. ; per do\%

Carnations-Handeowe garden sorts. Each 25 cts.; per doz ............ 2.5i Delphinium-(L8rkepur) - In variety; very fine. Each 20 cts ; per doz...2.00 Dicentra Spectabilis-(Bleeding Heart.) Each 20 cta.; per doz........2.00 Helianthus Multiflorus Fl. Pl. (See page 75.)

Helleborus Niger-(Christmas Rose.) Each 25 cts.; per doz............2.50 Hemerocallis Flava-(Yellow Day Lily.) Each $20 \mathrm{cts}$; per doz .......2.00 Hemerocallis Fulva-(Orange Day Lily.) Each 20 cts. : per doz .......2.00 Iris-In variety. Old favorites. Each $20 \mathrm{cts}$; per doz.................. Lychnis Chalcedonica-Large heade of bright scarlet flowers. Each.. .20 Lysimachia Nummularia - (Loosestrife) - Excellent for rockwork; flowers yellow. Each 20 cts; per doz.

Pæonies-Perfectly hardy plants of the easleetculture, and such free bloomers that they are always highly prized. White, Pink and Red.

Phlox-In variety. (See page 73 .

Veronica Grandis - Spikes of blue flowers, Each 20 cts.; per doz ......2.50

\section{HARDY CLIMBERS.}

Ampelopsis Quinquefolia-(Virginia Creeper)-A hardy climber of

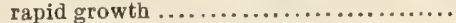
Ampelopsis Royali-(See page 74.) |Cinnamon Vine-(See page 78.) Ampelopsis Veitchil-(See page74.) Clematis-(See page 75.)

\section{HONEYSUCKLES.}

Anna Reticulata-A variety with a beautiful variegated foliage. Flower yellow and fragrant.

Chinese Twining Well known vine, holding its foliage nearly all winter. White flowers in July and Sep tember

H a 11 e a n a-chall's J a p a $\mathrm{n}$ ) - A strong, vigorous, fragrant variety producing fine white flowers, chang. ing to yellow; bloom ing from July until frost.

Monthly Fragrant -Blooms all summer. Red and yellow flower very frageant flowers...2 Scarlet Trumpet Rapid grower, and produces scarlet inodor ous flowers all summer

\section{WISTARIA.}

Chinese Sinensis - Vigorous grower. Has long pendulous clusters of pale blue flowers in May and June and in sutumn

Chinese White-The finest of all pure flowers. .

\section{CLIMBING ROSES. (See page 76.}

\section{CURRANTS.}

Strong two-year-old plants.

Black Naples-A black variety; large and pro ductive.

Cherry-Dark red; very large and productive White Grape-The best table variety; large and of fine flavor; very productive.

$$
\text { Each, 15c.; per doz., } \$ 1.50 \text {. }
$$

Fay's Proliflc-The largest and finest Currant grown; berries larger than the Cherry and more uniform; stem longer; fruit less scid. This Currant has superseded the Cherry and Ver ailles, both for market and home use. Color red. Each, 20 cts.; per doz, $\$ 2.00$.

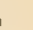




\section{0 - Currie Bros.' Hortieultural Guide.—- - -}

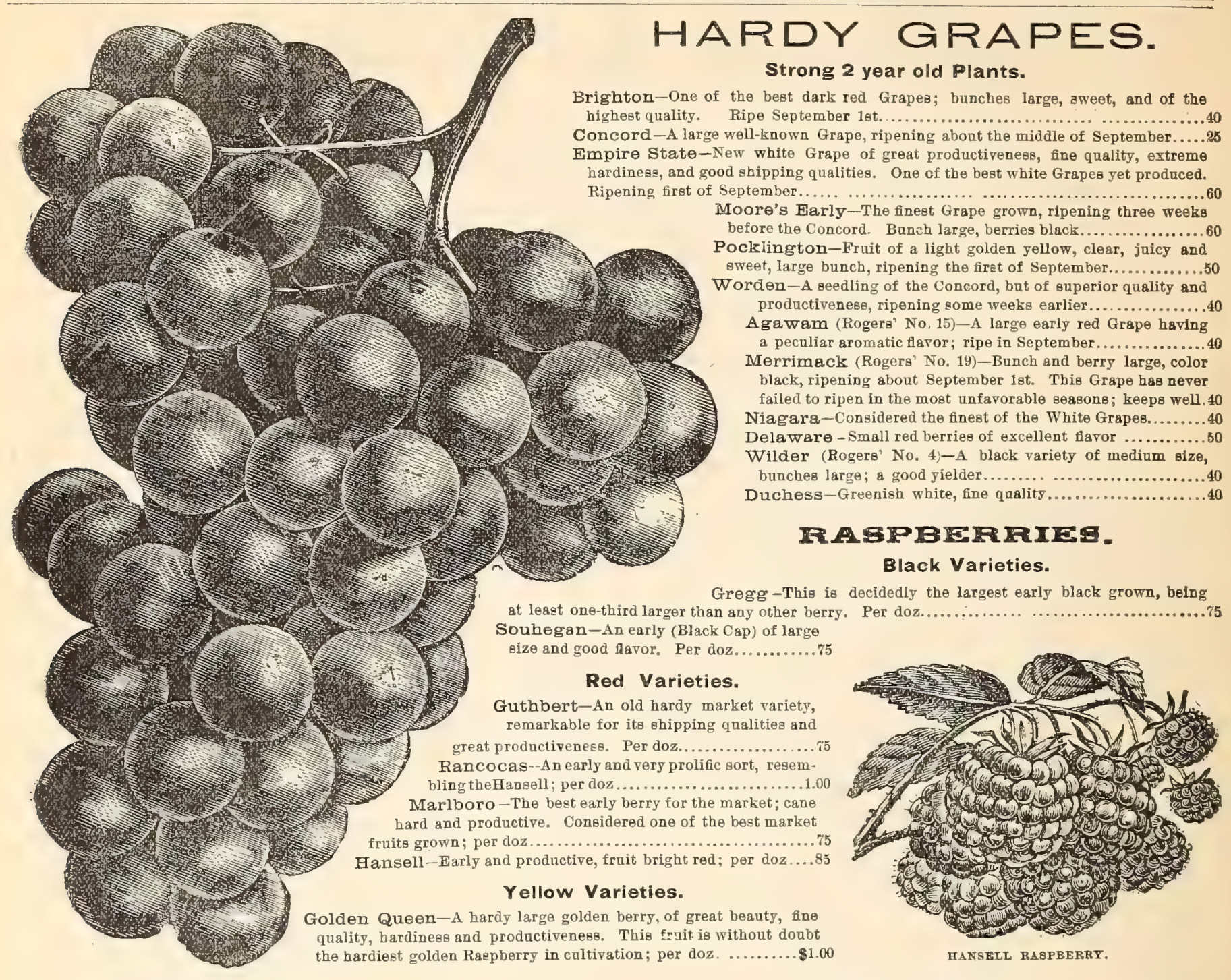

\section{BLACKBERRIES.}

Ancient Briton-The best and most profitable variety grown. It is enor mousious. Price, per doz., $\$ 1.00 ;$ per $100, \$ 8.00$.

Erie-Early, hardy and productive. Price, per doz., $\$ 1.00$; per $100, \$ 8.00$.

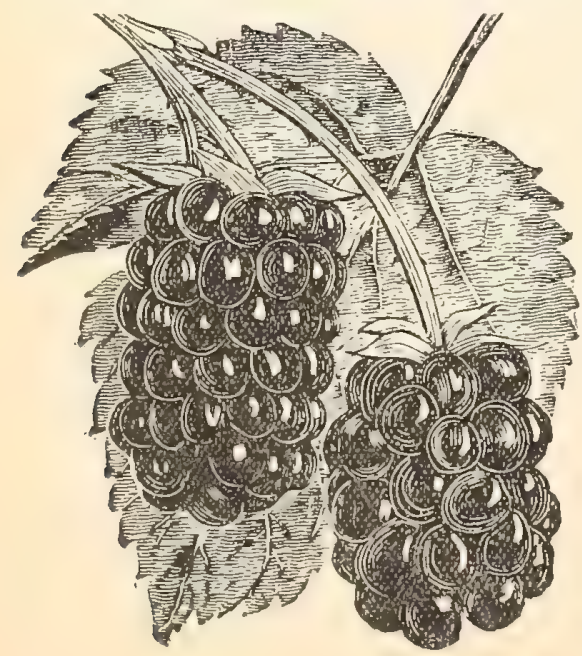

DEWBERRY.

Lucretia-(Creeping B lackberry)-Early, h a r d y and vigorous. per $100, \$ 8.00$.

\section{GOOSEBERRIES.}

\section{Industry - An English} variety of great worth, in fact the best Gooseberry grown either in this country or Europe. Fruit
dark red, and of the finest quality; never mildews. The berries attain a marketable size quite three weeks earlier than any other variety, and it is admitted to be the heaviest cropping Gooseberry cts. each; \$2.25 per doz. Dow ning - The best American variety, of a light green color, very $15 \mathrm{c}$ each; $\$ 1.50$ per doz.

\section{STRAWBERRIES.}

Wilson's Albany-Very productive. A standard market variety.

Crescent Seedling-Hardy, productive.

Jessie-Excellent sort; hardy, productive.

Warfield's No. 2-Highly esteemed for its large and uniform berries, and considered one of the very beat sorts for marketing. Being pistillate it should be planted with a good steminate variety.

Other Leading Market Sorts.

Price, 50 cts. per doz.; per 100, $\$ 2.00$.

\section{VEGETABLE PLANTS.} Cabbage.

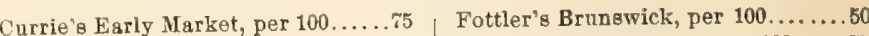
Currie's Eclipse, per 100...........75 Currle's Long Keeping, per 100 ....75 Early Wakefield, per $100 \ldots . . . \ldots . .75$ Red Pickling, per $100 \ldots . . . . . . .60$ Henderson's Summer, per 100......75 Dwarf Ulm Savoy, per 100.........50 Premium Flat Dutch, per 100.

\section{Cauliflower.}

Selected Dwarf Erfurt, per 100.... Snowball per $100 \ldots . . \$ 1.25 \mid$ Early Paris, per $100 \ldots . . . . . . . . .75$

\section{Celery.}

Golden Dwarf, per 100..........50 |White Plume, per $100 \ldots . . . \ldots .60$ Henderson's Half Dwarf, per $100 \ldots 50$ Celeriac, per $100 \ldots . . . \ldots \ldots \ldots . . . . .50$

Tomato Plants.

Of the leading sorts, seedlinge, per $100 \ldots \ldots \ldots \ldots$ Strong transplanted plsnte, per doz..................................2 


\section{(1)
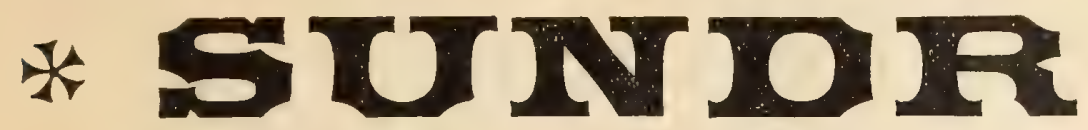

DOCK LIFTER.
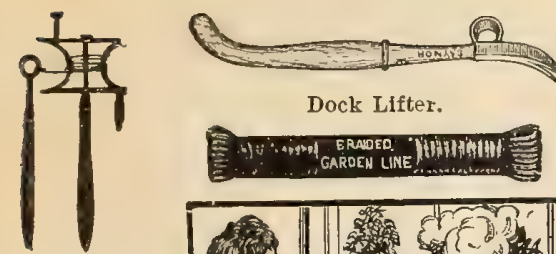

Dock Lifter.

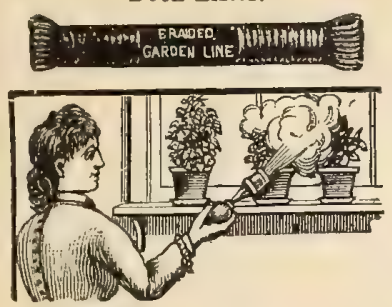

Ives' Hand Fumigator.

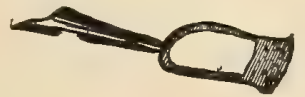

Scuffle Hoe.

Woeding Fork.
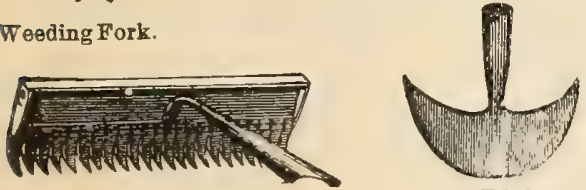

Daisy Rake.

Grass Edging Knife.
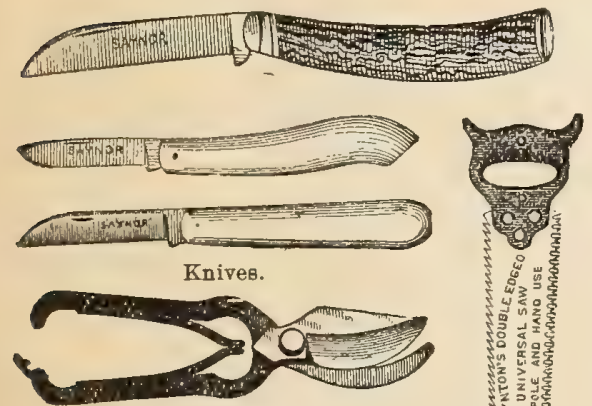

KNIVES.

Pruning. single blade, each.........\$1.00, 1.25, 1.50

two-bladed ......................................... (American Cocoa handle, iron cap)......1.00 Budding (English ivory handle) .................. 1.00 ASPARAG US KNIVES A.................. GRASS EDGING KNIVES (English): " 8 inches, $\$ 1.25 ; 9$ inches, $\$ 1.35 ; 10$ inches ............... 1.50

\section{LABELS.}

Pot, 4 inches, painted, 10 cte. per 100 ; per $1000 \ldots 75$

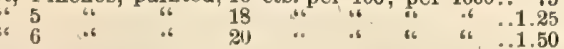

THE "NEW MODEL" LAWN MOWER.

For eimplicity, durability and quality of work, this mower is superior to any in the market, while for lightness of draft it excels any other lawn mower now manufactured. Four open knives.

$$
\text { PRICES. }
$$

10-inch cut, $\$ 5.20 \mid 14$-inch cut, $\$ 6.80 \mid$ 18-inch cut, $\$ 8.40$ 12-inch cut, $6.00 \mid 16$-inch cut, $\% .60$

\section{HARVARD LAWN MOWER.}

Also an excellent mower. Three open knives.

10-inch cut, $\$ 3.90 \mid 14$-inch cut, $\$ 5.10 \mid 18$-inch cut, $\$ 6.30$ 12-lach cut, $4.50 \mid 16$-inch cut, 5.70

PEAT.

For potting plante, excellent quality: per bbl.....2.50 POT COVERS.

Imported Fancy Papier Mache: No. 1, each 10 cts. per doz., $\$ 1.00$. No. 2 , each 15 cte; ; per doz....1.50 PLANT STAKES.

\section{PAPER}

Tissue, per ream .............................. Waxed manila, 100 oheeta, $\$ 1.50 ;$ per ream .........

PLANT SPRINKLERS.

Scollsy's Rubber Distributor.
Scollay"s Rabher, each, $\$ 100$; by mail ..........1.10 Best hard wood, double pointed, box 10 cte. ; 15

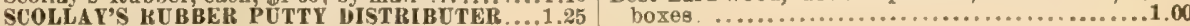

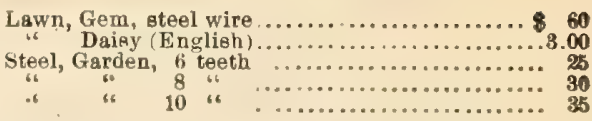

RAFFIA.

For tying; per pound..................... \&5

\section{HEDGE PRUNER OR SLASHER.}

DUNBE PATTERN

The most convenient and most effective instrument for pruning hedges, evergreen trees, or for cutting out underbrush ever devised. Made of the best steel and very durable; each...........1.00

PLANT PROTECTING CLOTH.

This is one of the grandest devices for the protection of plants from froet cold winde, heavy rains and a scorching sun ever invented. It is prepared in oil and is almost transparent so that it is a first class substitute for glass. It is light, very convenient when tacked on to wooden Per piece of 40 to 60 yards, $81 / 2$ cts. per yard

SAWS.

Lightning Pruning, 13 inch .....................00 SCYTHES.

English Lawn, 36-inch.

SCYTHE STONES, round Talacre, each.

BEST IMPORTED SHEARS.

SHEARS, BORDER, 8-inch, each ..............2.25 9 -inch, each $\ldots . . . \ldots \ldots \ldots \ldots .2 .50$

With whel, 50 cts. extre.

HEDGE, 8-inch 9-inch.

1.50 10 inch....................2.00

With notch to prevent slipping when cutting LOPPING, amall \$2.00; medium.........2.50

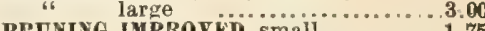
PRUNIV IMPROVED, smail ............1.75 small, for trimming Roses..... 75 American LA W N, with two wheels: 8 inches, $\$ 3.00$; LAWN, without wheels: 8 inches, $\$ 2.50 ; 9$ inches, $\$ 2.75 ; 10$ inches, $\$ 3.00$. Flower Gatherers, small, nickel-plated... 50 Grape Thinning, bright steel blades...... 75

\section{SICKLES.}

Grass Hooks (Sickles) small

medium

SYRINGES.

No. $1,12 \frac{1}{2} \times 1$ 5-16, one spray....2.00 No. $2,131 / 2 \times 1$ 5-16, two sprays and one stream, $\ldots \ldots \ldots \ldots . . . . . . .3 .30$ stream $\ldots \ldots \ldots \ldots \ldots \ldots . . \ldots \ldots$ No, $5,18 \times 11 / 2$, two sprays and one stream, bett for greenhone on stream, patent valves ........5.50 No. 7, same as No. 5, with knuckle Tin Japanned, one spray.....................00

\section{THERMOMETERS.}

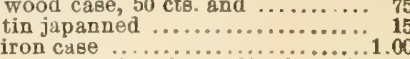
double registering, showing the TIN FOIL.

ООтн PICKS. 


\section{IMPLEMENTS. \\ IIIPLEM}
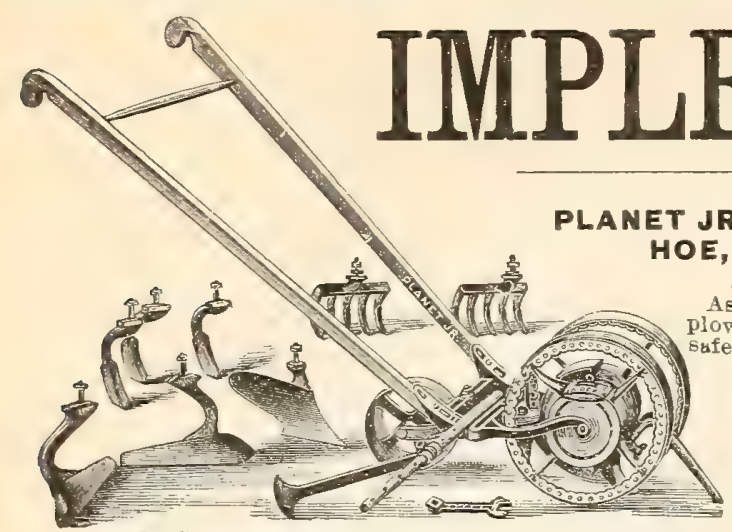

PLANET JR, COMBINED DRILL, WHEEL HOE, WHEEL CULTIVATOR AND WHEEL PLOW

As a Plow it opens furrowe, covers them, hille plows to and from, etc., etc. As a Hoe, it works

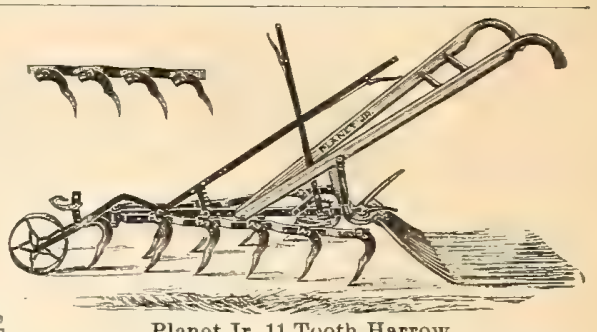
row at once, or between row s as plants be

With Lever Attachments, $\$ 7.50$. With Pulverizer. come larger, working all rows from eight to sixteen inches wide at one passage. As a cultivator, it is admirably adspted to deep mellowing of the soil. rakes are invaluable in preparing the soil for planting.

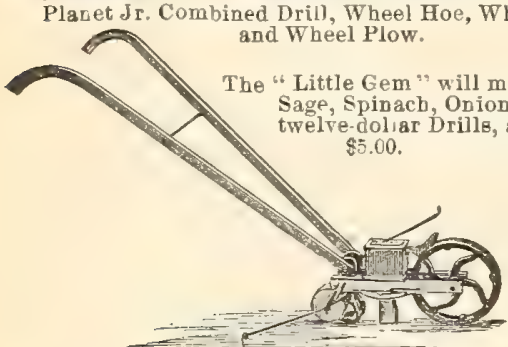

Little Gem Seed Drill.

LITTLE CEM SEED DRILL.

Price, bozed, \$8.75.

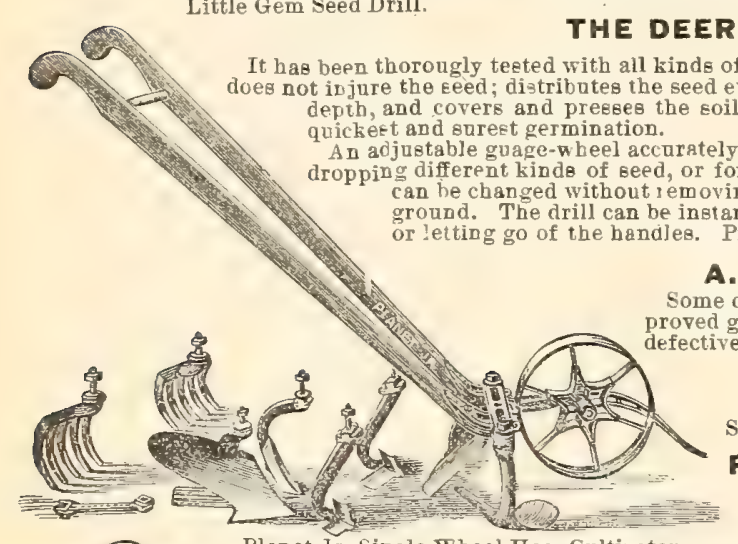

THE GEM OF THE CARDEN. Wheel Hoe and Cultivator.

As lately improved, we can offer the above implements to gardener and others with the assurance that it is fully up to the timee,

It equipment five wive steel teeth and two plows-right and leit hand. Price, boxed, $\$ 4.00$ With double wheel attachment and two extra steel blades (shown at point $\mathrm{A}$ in cut), THE DEERE CARDEN SEED DRILL.

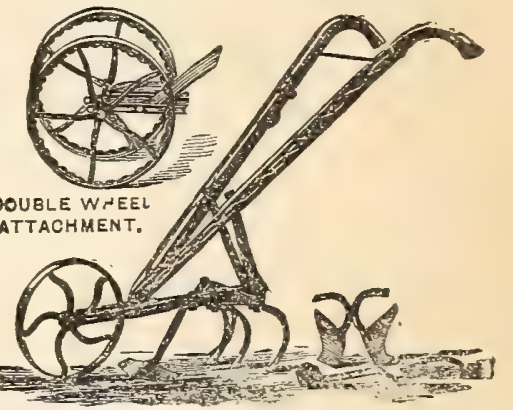

The Gem of the Garden.

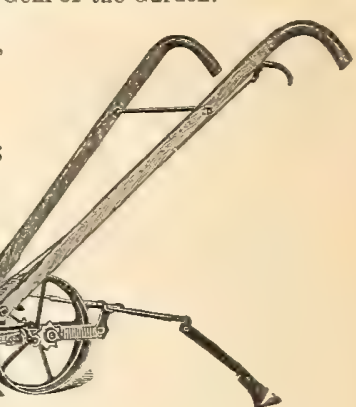

The Deere Garden Seed Drill.

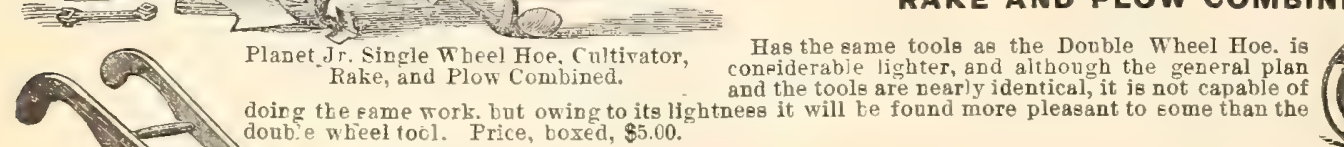

THE "FIREFLY" SINGLe WHEEL HOE, CULTIVATOR AND PLOW COMBINED.

MATTHEWS' SEED DRILL. imilar to the A. H. Matthen s' in some respects. Seed box round. Price, $\$ 8.00$

PLANET JR. SINCLE WHEEL HOE, CULTIVATOR, RAKE AND PLOW COMBINED.

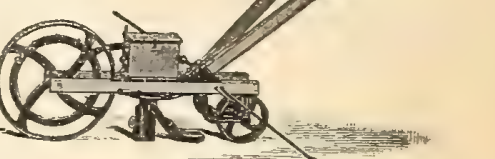

A. H. Matthews' Seed Drill

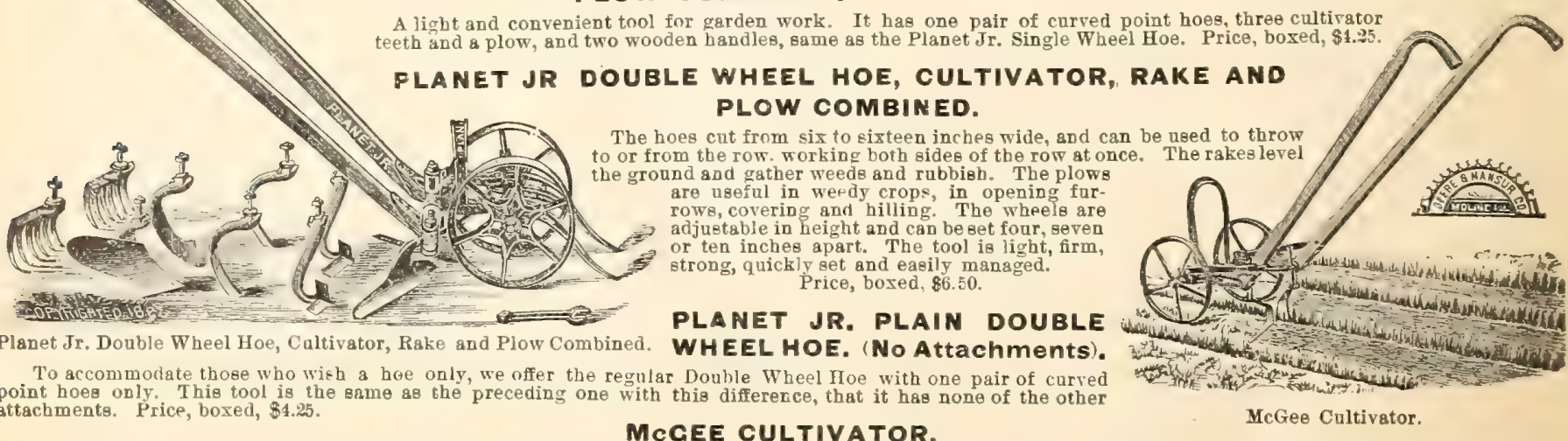

MCGEE CULTIVATOR.

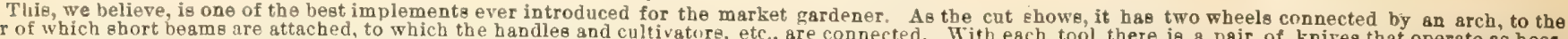

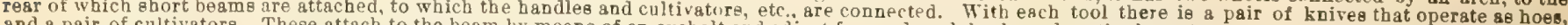

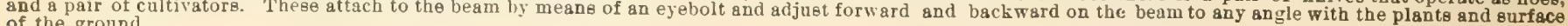
The adjustmer protect the plants. Price, $\$ 500$ 


\section{0 - Currip Bros.' Hortieultural Guide.———ut}

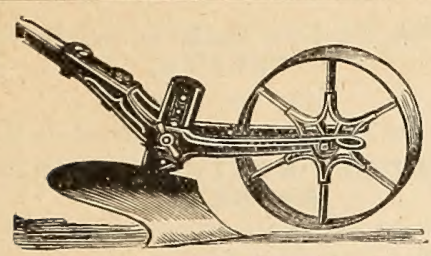

The "Fire-Fly" Wheel Garden Plow

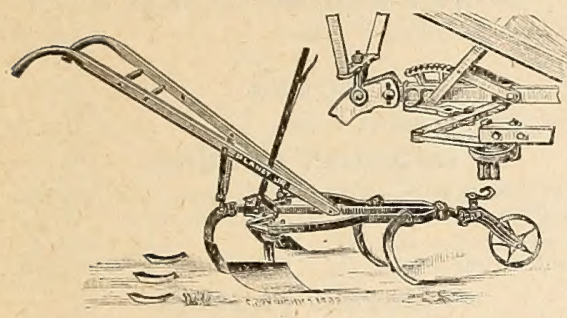

Planet Jr. Steel Standard Cultivator.

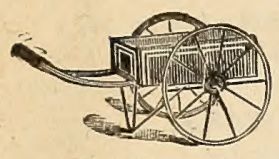

Hand Cart.

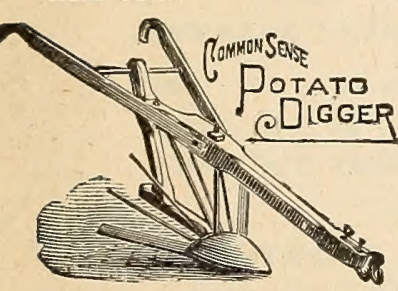

Common Sense Potato Digger. Price, $\$ 6.50$

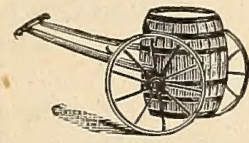

Barrel Cart

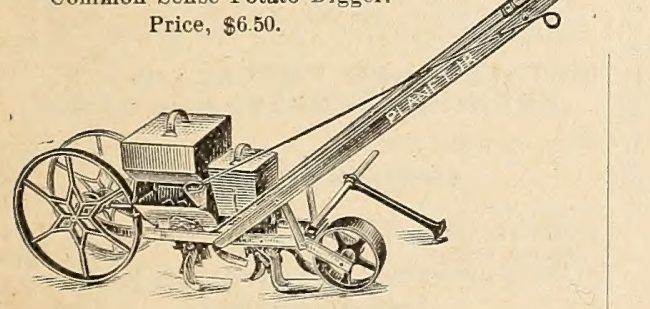

PLANET JR. COMBINED HILL DROP. PING AND FERTILIZER DRILL.

This tool sows in drills as well as No. 2 Drill, and will also drop the seed in hills either four, eix, eight or twelve inches apart. The fertilizer hopper holds one peck and can be regulated to drop any quantity. Either the Seed Drill or Fertilizer attachment can be thrown out of gear at pleasure. Price, $\$ 18.00$.

PLANET JR. HILL DROPPING GARDEN DRILL, Without Fertilizer Attachment. Price, $\$ 12.00$.

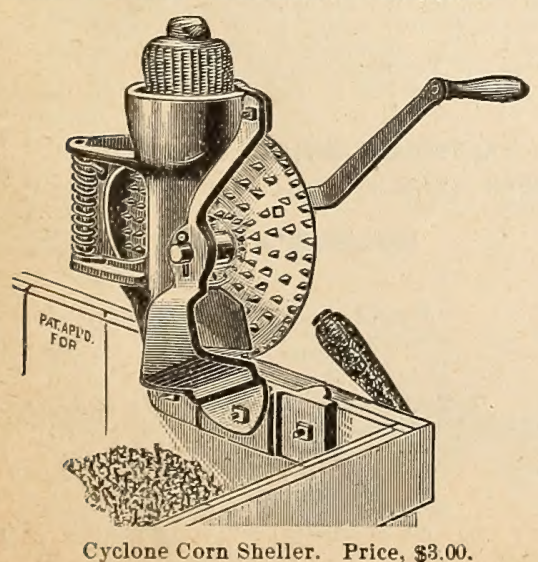

THE "FIRE-FLY" WHEEL GARDEN PLOW.

This tool can be quickly adjusted to work shallow or deep. It takes the place of the horse and plow, or cultivator, requiring no wide headlands to turn on and is invaluable during all the gardening season. Price reduced to $\$ 2.50$.

IMPROVED PLANET JR. HOLLOW STEEL STANDARD HOE AND CULTIVATOR WITH WHEEL.

A great improvement has been made the past year on this excellent horse cultivator. On the old pattern the frame and side teeth, which are adjustable from 5 inches to 24 inches apart and to any desired angle, had to be set by bolts and nuts; but in the improved style the adjustments are made by the aid of levers as shown in the cut. Complete with Wheel, price $\$ 8.00$.

Roller for covering $\$ 2.00$ Extra. Marking attachment. 2.00 Covering Rake. 1.25 Extra eet of 5 cultivators.............. 1.00

NEW MODEL SEED DRILL.

A very desirable Garden Drill of simple construc tion. Price, $\$ 6.00$.

\section{BARREL CART.}

For slops, water, potatoes, apples, etc. An old kerosene barrel will fit into the frame, all the attach ments are furnished

Without barrel, price $\$ 5.00$.

HAND CART.

Weight, 80 pounds. Price. $\$ 6.50$

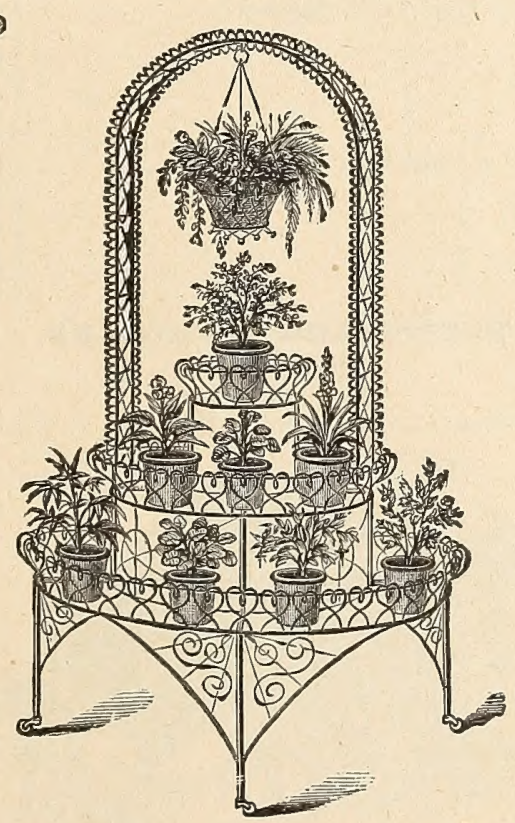

WIRE PLANT STAND.

Height, $6 \mathrm{ft}, 2$ in. Width, $2 \mathrm{ft} .7$ in. Length, $4 \mathrm{ft}$. Each, $\$ 6.50$.

A complete list of Wire Plant Stands, etc., furnished upon application.

Write for special prices on Plows, Har rows, Feed Cutters, Road Scrapers, Corn Planters, Field Rollers, Hay Rakes, Corn Shellers, Disc Harrows, Etc.

\section{FERTILIZERS.}

\section{CURRIE'S SPECIAL LAWN} FERTILIZER.

A preparation which never fails to induce a rapid and healthy growth to the lawn. It is also of great value as a fertilizer for root crops, etc. $1 \mathrm{lb}$., 10 cte.; 5 lbs., 40 cts.; 10 lbs., 60 cts.; 25 lbe., $\$ 1.25$; 50 lbs. $\$ 2.00 ; 100$ lbs., $\$ 3.50$.

\section{PURE BONE MEAL.}

Our Bone Meal is ground fine, and is of great value mixed with soil for potting purposes, for which one part of meal to 10 of soil is about the right propor tion. It is invaluable for top-dressing lawns; 5 lbs. 30 cts :; $10 \mathrm{lbs}, 50$ cts.; 25 lbs., $\$ 1.00 ;: 0$ lbs., $\$ 1.50$ $100 \mathrm{lbs}$., $\$ 2.50$; barrel of $200 \mathrm{lbs}, \$ 4.50$.

\section{PERUVIAN GUANO.}

Guano is one of the best and most powerful stimulants for plants and growing crops. One pound of Guano to twenty gallons of water will be sufficiently strong for a single watering each week, and more efficient than repeated waterings with weaker solutions. Per lb., 10 cts. ; 12 lbs., 80 cts.; $23 \mathrm{lbs}$, $\$ 1.10 ; 100 \mathrm{lbs}$. $\$ 4.25$; per bag of 200 lbe., $\$ 8.00$. Prices per ton on application.

BOWKER'S PLANT FOOD.

In packets, with instructions for use. Each 15 and $30 \mathrm{cts}$. By mail, 20 and $40 \mathrm{cts}$.

\section{EXCELSIOR PLANT FOOD.}

In packets, 15 cts. By mail, 20 cts.

LAND PLASTER OR GYPSUM. In barrele of about $\$ 35$ lbs............... $\$ 2.00$

\section{INSECT DESTROYERS.}

Gishurst's Compound, package ............ \$ 50

Fir Tree Oil, pint, i5c.: quart ............... 1.50

Flowers of Sulphur, pound $\ldots \ldots$

Hellebore, pound ...................... 50

Paris Green, pound

Slug Shot, valuable for destroying slugs on cabbages, tomatoes, currants, etc., and is also very effective in removing potato bugs; pound, Ec. 100 pounds

Grape Dust, a sure preventive and cure for mil

dew on Roses, Grapes, Gooseberries, etc.; per

1b., 10c.; 5 1bs., 35c.; 10 1bs., 60c.; 100 1bs...... 5.00 Tobacco Dust, pound........................ 10

Tobacco Stems, pound, 3c : barrel.......... 1.00 Whale Oil Soap, pound.

Dr. Wolf's Soap, package

Pereian Insect Powder, pound If by mail add 15 cts, a pound.

Apparatus for Applying Insect Destroyers. Bellows No. 9, 10 cts.; No. 11, 75 cts.; No. 14, $\$ 1.00$; No. $16, \$ 1.25$; No. $19, \$ 1.50$; No. $22, \$ 1.75$; No. 24 ; $\$ 2.00$.

Tin Dusters for Applying Slug Shot, $1 / 2$ gallon, each 35

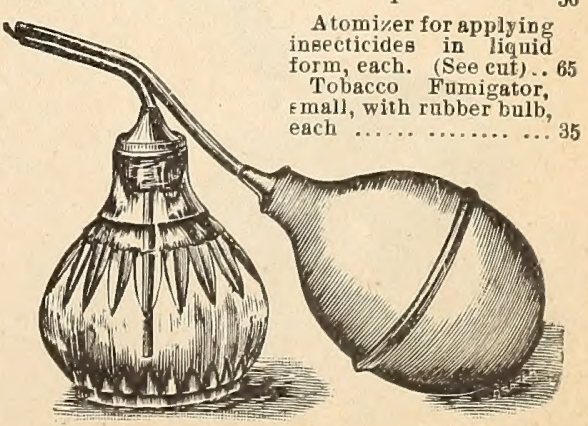

ATOMIZER. 


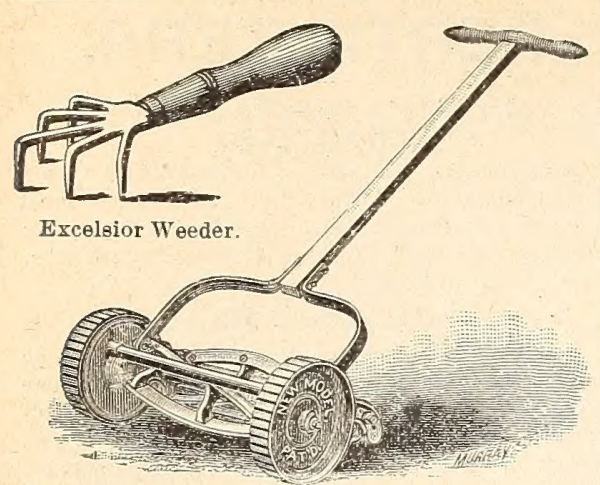

The "New Model" Lawn Mower.
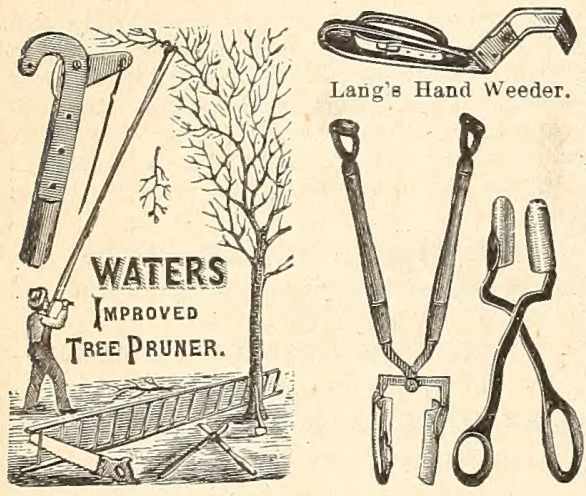

Avery Transplanters.

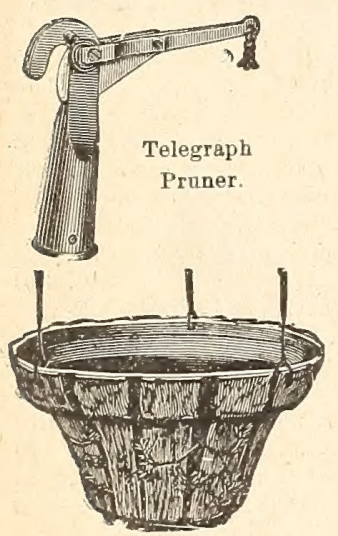

Terra Cotta Rnstic Hanging
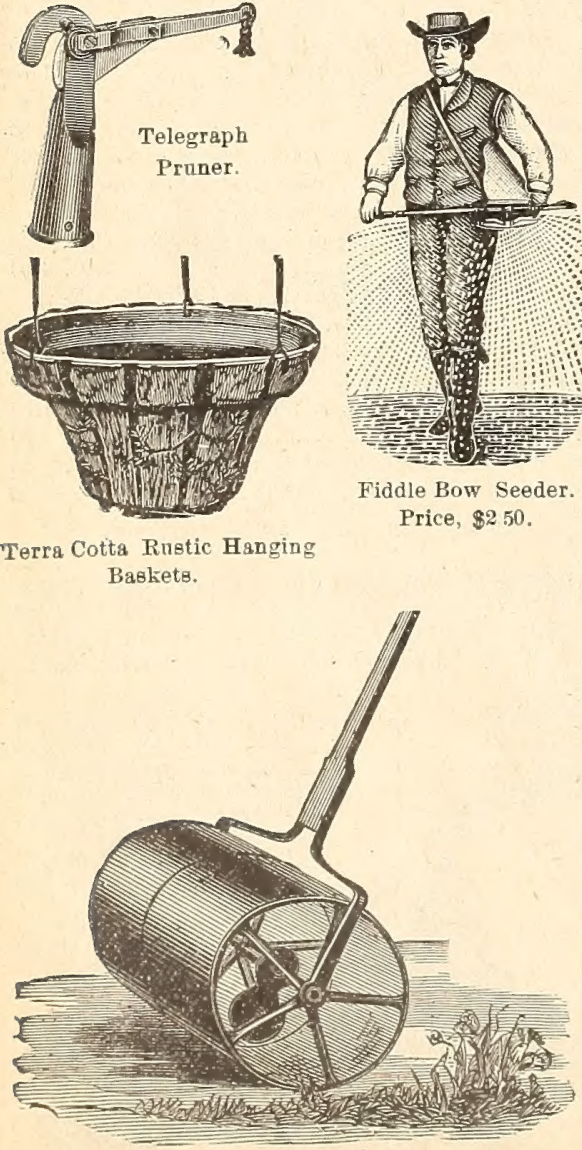

Iron Lawn Roller.
AVERY TRANSPLANTER.

Avery Transplanter, small, 50 cts. ; large...... $\$ 2.00$ TROWELS.

Trowels, American, each, 5-inch.:

English steel, each, 6-inch solid blade, all one piece,

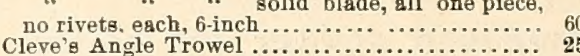

\section{TREE PRUNERS.}

6 foot pole.

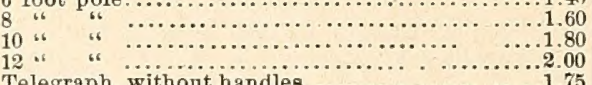

Telegraph, without handles..................75

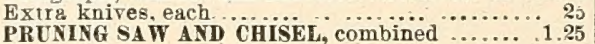

\section{WOODEN TRELLISES.}

For training plants, useful as well as ornamental. 18 inch.... 20
30

\section{TWEEZERS FOR ARRANGINC FLOWERS.}

For arranging flowers, 5-inch, 20 cts. ; 6 -inch.

\section{LANG'S HAND WEEDER.}

Gives perfect use to the hand for pulling weeds and thinning plants without laying down the tool, Price, each

\section{EXCELSIOR WEEDER.}

An implement that can be need to advantage among small and tender plants.

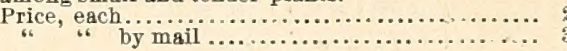

\section{FLOWER POTS AND SAUCERS.}

\section{Per}

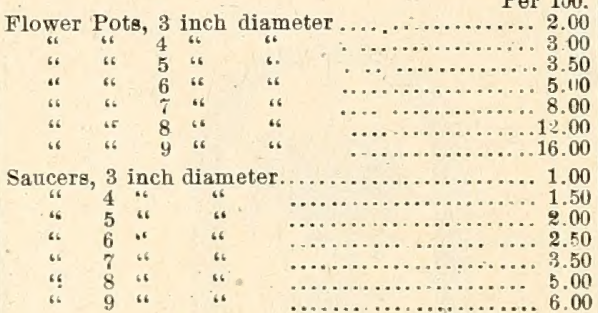

\section{RUSTIC FLOWER POTS AND SAUCERS.}

Large 8ssortment.

$41 / 2$ inches to 15 inches. Each $20 \mathrm{cts}$. to
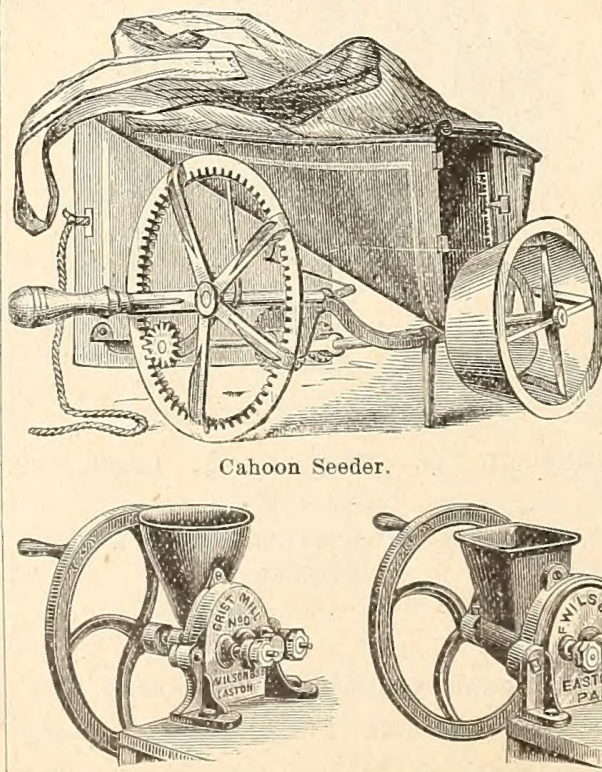

Family Grist Mill.

TERRA COTTA RUSTIC HANGINC BASKETS.

Large assortment.

8 inches to 12 inches in diameter. Each 25 cts. to $\$ 1.00$ WOODEN RUSTIC HANGING BASKETS

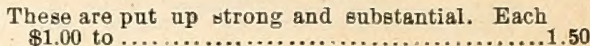
WIRE HANCINC BASKETS.

10 inches in diameter. Esch.................. 35 12

Good Birds. Each $\$ 3.00$ and.............
BOUQUET PAPERS.

FANCY ITALIENS - We have a large stock of the beet patterns. Measure does not include lace.

$\begin{array}{llllllll}\text { Inches.... 3 } & 31 / 2 & 4 & 41 / 2 & 5 & 51 / 2 & 6 & 61 / 2\end{array}$

\section{0}

ORNAMENTAL CRASSES IN VARIETY.

Per pound........................... $\$ 1.00$ to 2.00 CAPE FLOWERS.

Dried Cape Flowers, white, per doz............ 10 WHEAT SHEAVES.

Standing Sheaf, solid. ......... $\$ 1.00 \quad \underset{1.25}{\mathrm{~A}} \quad \begin{gathered}\mathrm{C} \\ 1.50\end{gathered}$

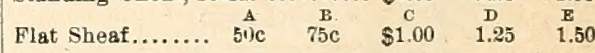
FAIRY FLOWERS.

Pure white, per doz
Colored, per doz

\section{WREATHS.}

Made of Cape Flowers and handsome artificlal

flowers. Each $\$ 1$ on to.......................... handsome and durable. Each from $\$ 1.50$ to ...10.00

\section{METALLIC AND PORCELAIN}

ANCHORS, CROSSESAND STARS

Each, from $\$ 2.50$ to ......................... 10.00 SPHAGNUM MOSS.

Bushel, 50 cts,; bale .......................2.00 IMMORTELLES, blue, white, purple, red, black, FRENCH, GREEN MOSs, per packet, is cts. and ... LYCOPODIUM.

1.00 Known also as Ground Pine, Bouquet Green and Princese Pine. Per lb..... .............. 10
Write for special prices on large quantities. IRON LAWN ROLLERS.

1 section 20 in. long 20 in. diameter, $250 \mathrm{lbs} . . \ldots 12.50$

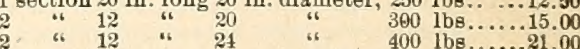

\section{CAHOON BROADCAST SEEDER.}

This is an excellent hand seeder. It is easily handled, being suspended by a strap over the shoulders, leaving the hands free. Four to six acres can be sown evenly in an holir, scattering Wheat, Rye, and Barley 25 feet; Oats, 23 feet Clover and Timotliy, 18 to 20 feet. The box and hopper hold about 22 quarts. Weight, $51 / 2$ lbs.

.

\section{GARDEN WHEELBARROW.}

JOSEPH WHEELBAREOW. With iron or wood wheel. Price ................................2.25 WILSON'S BONE MILLS.

\section{No. 1 Mill.}

For grinding dry bones, shells, grain and any other substance for poultry. Can be adjusted for grinding either Without iron legs, weight $35 \mathrm{lbs}, \ldots .4 .50$ With iron legs, weight $64 \mathrm{lbs} . . . . . . .66 .50$

\section{FAMILY GRIST MILL.}

For grinding corn meal, Graham flour. Wilson`s Bone Mill. 


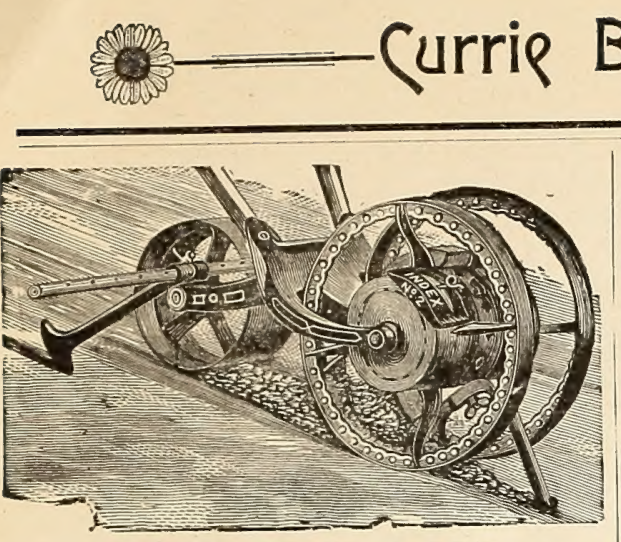

PLANET JR. NO. 2 DRILL.

Holds $2 \frac{1}{2}$ quarts. It has a finely adjustable spring brass seed hopper, and an adjustable plow between the carrying and covering wheels, the new permanent seed index, the cleaner and marker, all combining to make a perfect tool. Price, boxed, $\$ 7.50$.

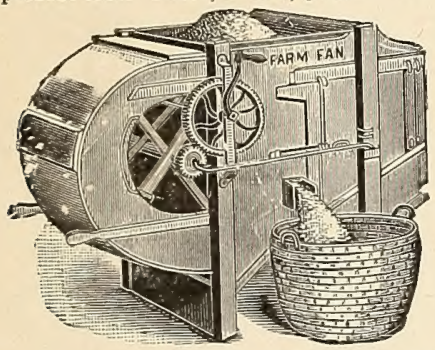

NO. I IMPROVED EXCELSIOR FANNING MILL.

For general purposes we believe this mill has no superior and will compare favorably with any on the market.

The regular outfit known as "Commercial" will be sent with each mill unless otherwise specified, and i as foilows:

1 W' heat Hurdle or Gang, with Zinc Sieve on Top
Wheat Screen; 1 Wheat Grader; 1 Oat Sieve and 1 Barley Sieve.

Other Sieves for special purposes furnished atreasonable prices and charged for extra.

Will be shipped knocked down unless otherwise ordered.

The sieves are larger than usual, being 24 inches instead of 22 inches. Price, $\$ 15.00$.

Standard Books for the Garden and Farm.

ASPARAGUS CULTURE...........Flex. Cloth. $\$ .50$ BARRY'S FRUIT GARDEN. New and Revised

Edition.

BEAL'S GRASSES OF NORTH AMERICA...2.50

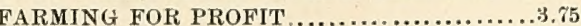

FITZ'S SWEET POTATO CULTURE.

FLINT'S GRASSES AND FORAGE PLANTS. .2.00

FRENCH'S FAR Y DRAINAGE.

FULLER'S PRACTICAL FORESTRY.

FLAX CULTURE-SEVEN ESSAYS BY PRAC-

TICAL GROWERS

HOP CULTURE.

MUSHROOMS-HOW TO GROW THEM.

SAUNDERS ' INSECTS INJURIOUS TO

FRUI'TS.

ELLIOTT'S HA NDBOOK OF PRACTICAL

LANDSCAPE GARDENING.

FULLER'S GRAPE CULTURIST

ROBINSON'S FERYS IN THEIR HOMES

AND OURS . . . . . . . . . . . . . . . . . . .

HEATLEY'S EVERY MAN HIS OWN VETERINARIAN .........................2.50

MAYHEW'S ILLUSTRATED HORSE DOCTOR.3.00

JENNING'S ON CATTLE AND THEIR DIS. EASES..

HARRIS' TALKS ON MANURES ...........

LONG'S ORNAMENTAL GARDENING .....2.2.00

VILLE'S SCHOOL OF CHEMICAL MANURES.1.

HIBBARD'S AMATEUR GREENHOUSE AND

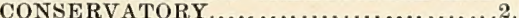

ASHLAND

MLS\&W.RY.

ROUTE

\& WESTERN R'Y.

THROUGH SIEEPING AND PARLOR CAR LINE

드솦 IIRAINTS

Chicago aNd MilwaUkeE

Appleton, Wausau and Ashland,

THE GOGEBIC, PENOKEE AND MONTREAL

IRON AND MINERAL RANGES

Hulley, Ironwood, Bessemer and Wakefield,

The Manufacturing Centers and Lumbering Di ricts of Central and Northern Wieconsin

Sheboygan, Mani'owoc, Kaukauna, Appleton, Wausau, Antigo, Eagle River and Rhinelander.

The only line reaching the celebrated fishing resorts of Northern Wisconsin and Michigan.

Gogebic, Tomahawk and Pelican Lakes.

Rhinelander, Eagle Waters, Twin Lakes, Lake Vieux Desert, Watersmeet

The Ontonagon, Brule and 0 iher Trout Streams.

Noted for their excellent Muskallonge, Bass, Pike, Pickerel and Trout Fiahing.

DIRECT LINE

Via NEW LONDON JUNC. and G. B. W.\& St. P. R. R.

SEYMOUR, GRAND RAPIDS \& STEVENS POINT,

Tia ASHLAND and NOR'THERN PACIFIC RAILROAD SUPERIOR, WEST SUPFRIOR, DULITII,

PACIFIC COAST and Intermediate Points.

Guide Books, Maps, Time Cards, and full informstion furnished on application to the General

Milwaukee City Offce, 100 Wisconsin St. Chicago City Office, 197 Clark St.

H. F. WHITCOMB, $\quad$ C. L. RYDER,

General Manager.

\section{THOS. W. WEATHERED'S SONS Horticultural Builders}

\section{IMPROVED BOILERS}

FOR HEATING

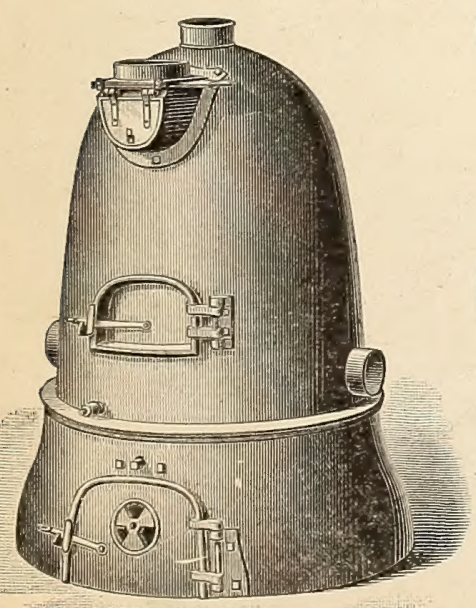

BOILER-Outside View.
Greenhouses, Graperies, Poultry Houses and Dwelling Houses.

Heating Pipes, Expansion Tanks, Stop Valves, Pipe Fittings,

Manufactured Expressly for Greenhouse Purposes.

PATENT VENTILATING APPARATUS

For Raising Sashes in Greenhouses, Galvanized Screw Eyes and Wire for Trellis Work.

Greenhouses, Conservatories, Etc., of Wood, or Iron and Wond combined, erected complete in any part of the United States or Canada.

THOS. W. WEATHERED'S SONS, 244 Canal St., NEW YORK.

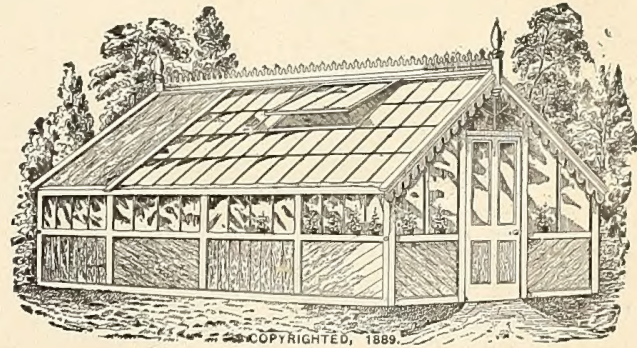

A donble span, portable Greenhouse, $8 \times 12$ feet, similar to cut herewith, with benches and heating apparatus complete, and boiler house $4 \times 4$ attached, delivered on cars in New York, for $\$ 260$. No brickwork is necessary, and can be put up by any carpenter or mechanic in one day.

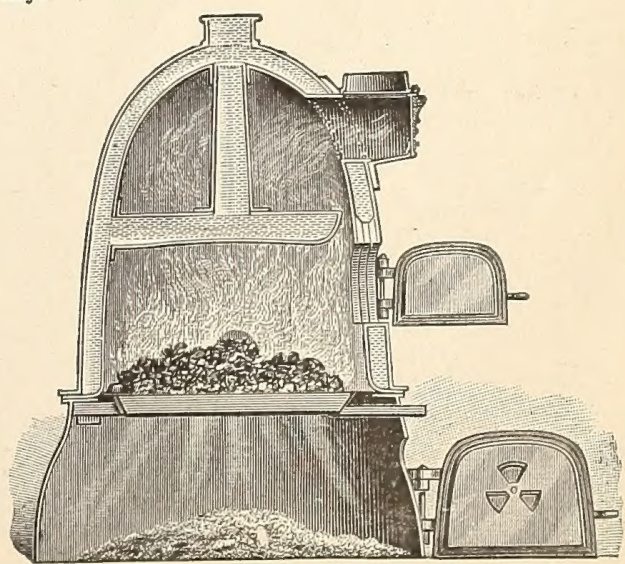

BOILER-Sectional View. 


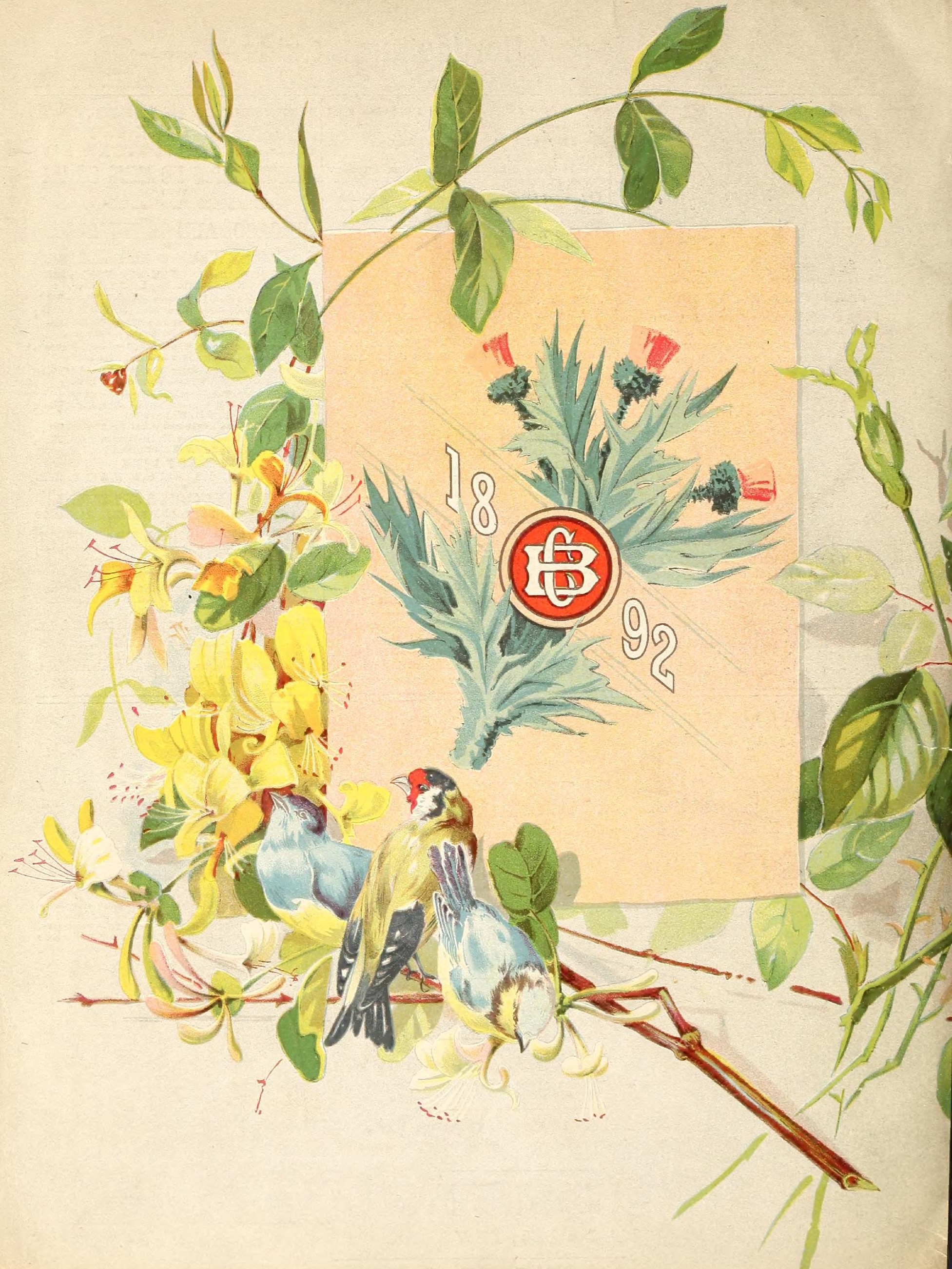

